Assessment of Effectiveness of Geologic Isolation Systems

\title{
Solution Mining in Salt Domes of the Gulf Coast Embayment
}

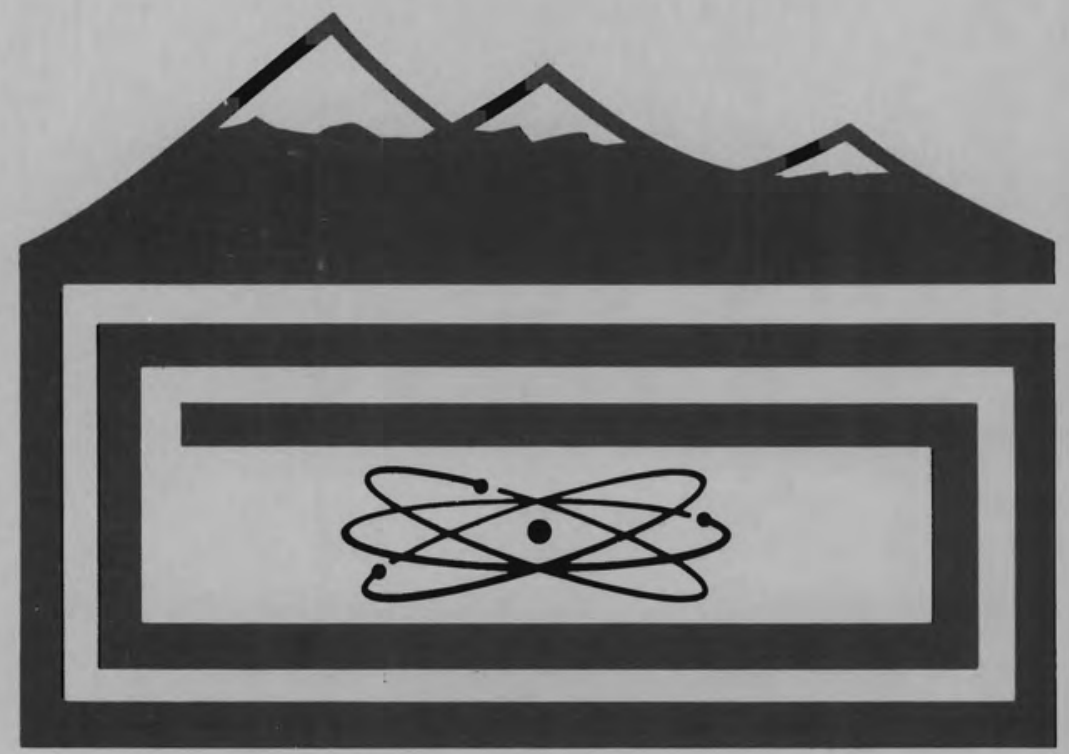

February 1981

Prepared for

the Office of Nuclear Waste Isolation

under Contract DE-AC06-76RLO 1830

Pacific Northwest Laboratory

Operated for the U.S. Department of Energy

by Battelle Memorial Institute 


\title{
NOTICE
}

This report was prepared as an account of work sponsored by the United States Government. Neither the United States nor the Department of Energy, nor any of their employees, nor any of their contractors, subcontractors, or their employees, makes any warranty, express or implied, or assumes any legal liability or responsibility for the accuracy, completeness or usefulness of any information, apparatus, product or process disclosed, or represents that its use would not infringe privately owned rights.

The views, opinions and conclusions contained in this report are those of the contractor and do not necessarily represent those of the United States Government or the United States Department of Energy.

\author{
PACIFIC NORTHWEST LABORATORY \\ operated by \\ BATTELLE \\ for the \\ UNITED STATES DEPARTMENT OF ENERGY \\ Under Contract DE-AC06-76RLO 1830
}

\author{
Printed in the United States of America \\ Available from \\ National Technical Information Service \\ United States Department of Commerce \\ 5285 Port Royal Road \\ Springfield, Virginia 22151
}

Price: Printed Copy \$

-; Microfiche $\$ 3.00$

NTIS

*Pages Selling Price

$\begin{array}{rr}001-025 & \$ 4.00 \\ 026-050 & \$ 4.50 \\ 051-075 & \$ 5.25 \\ 076-100 & \$ 6.00 \\ 101-125 & \$ 6.50 \\ 126-150 & \$ 7.25 \\ 151-175 & \$ 8.00 \\ 176-200 & \$ 9.00 \\ 201-225 & \$ 9.25 \\ 226-250 & \$ 9.50 \\ 251-275 & \$ 10.75 \\ 276-300 & \$ 11.00\end{array}$


PNL-3190

Special

Distribution

33679000537771

SOLUTION MINING IN SALT DOMES

OF THE GULF COAST EMBAYMENT

G. B. Griswold

Tecolote Corporation

February 1981

Prepared for the

Office of Nuclear Waste Isolation under its Contract with the

U.S. Department of Energy

$\boldsymbol{a}$

Pacific Northwest Laboratory

Richland, Washington 99352 
$+$ 


\section{ACKNOWLEDGMENT}

This research was supported by the Waste Isolation Safety Assessment Program (WISAP) conducted by Pacific Northwest Laboratory. The program was sponsored by the Office of Nuclear Waste Isolation, managed by Battelle Memorial Institute for the Department of Energy under Contract EY-76-C-06-1830. On 1 October 1979 WISAP was divided into two programs with separate areas of concern: the Assessment of Effectiveness of Geologic Isolation Systems (AEGIS) Program and the Waste/Rock Interactions Technology (WRIT) Program. This report was issued by AEGIS under Contract DE-AC06-76RLO 1830. 
• 


\section{CONTENTS}

ACKNOWLEDGEMENT

FIGURES

TABLES

INTRODUCTION

SALT RESOURCES .

PRODUCTION OF ROCK SALT AND BRINE FROM SALT DOMES . . . . . 3

ESTIMATE OF THE TIME THE UNITED STATES WILL HAVE EXPLOITED

MOST SALT DOMES IN THE GULF COAST EMBAYMENT.$\quad \cdot \quad \cdot \quad \cdot \quad \cdot \quad \cdot \quad 8$

DESCRIPTION OF CONVENTIONAL MINING .

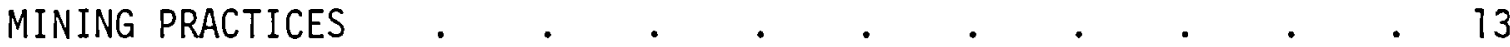

MINE SAFETY

SIGNIFICANCE TO WASTE ISOLATION SAFETY ASSESSMENT . . . . . 14

SOLUTION MINING

GENERAL COMMENTS $\quad . \quad \cdot \quad \cdot \quad \cdot \quad \cdot \quad \cdot \quad \cdot \quad \cdot \quad \cdot \quad \cdot 15$

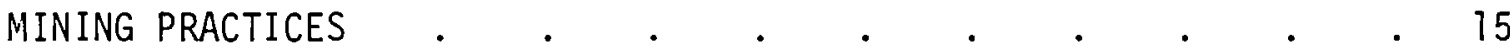

BRINING TO PRODUCE SALT WATER VERSUS SOLUTION MINING FOR

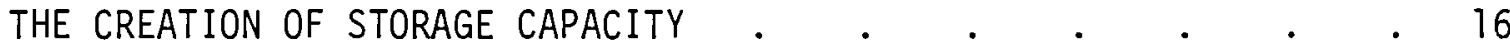

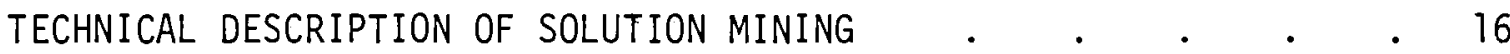

TECHNICAL DESCRIPTION OF BRINING OPERATIONS • • • . $\quad . \quad$. 19

DATA CONCERNING CAVERN SHAPE AND VOLUME . . . . . . . . . 19

SIGNIFICANCE TO WASTE ISOLATION SAFETY ASSESSMENT • • • • • 44

BREACH SCENARIO WHICH COULD LEAD TO RELEASE OF RADIOACTIVE WASTE

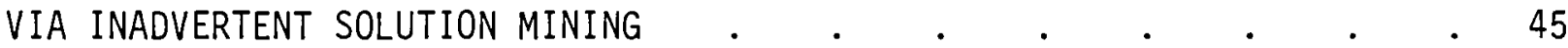

SITE SELECTION •

EARLY DETECTION OF THE PRESENCE OF RADIOACTIVE WASTE • • • • 46

SOLUTIONING BEGINS. WHEN WILL THE CONTAMINATION BE DETECTED? • 46

AT WHAT RATE WILL CONTAMINATED BRINE BE PRODUCED • • • • • 47

WHAT WILL HAPPEN TO THE BRINE PRODUCED? . • . . . . . . 47

WHAT WOULD OCCUR IF A CAVERN INADVERTENTLY BREACHES TO THE

SUMMARY OF CONCLUSIONS RELATED TO A RELEASE SCENARIO BASED ON

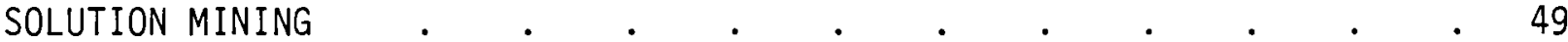

APPENDIX A: ANNOTATED BIBLIOGRAPHY OF GEOLOGICAL DOCUMENTS RELATED

TO THE STRATEGIC PETROLEUM RESERVE PROGRAM $\quad \cdot \quad \cdot \quad \cdot \mathrm{A}-1$

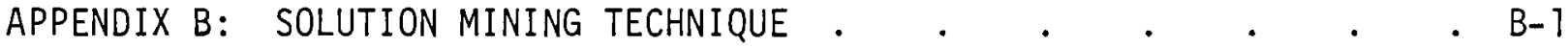

APPENDIX C: THE DEPARTMENT OF ENERGY STRATEGIC PETROLEUM RESERVE. . C $\mathrm{C}-1$ 


\section{FIGURES}

1 Marine Evaporite Deposits of the United States . . . . 4

2 Location of Domes in the Gulf Coast Embayment . . . . . 7

3 Dry Salt Production Sites United States and Canada . . . . 9

4 Alternate Concept for Concurrent Leaching and Storage . • 17

5 Cavern Classification - Bayou Choctaw . . . . . . 21

6 Profile - Cavern No. 1 - Bayou Choctaw Dome . . . . . 23

7 Cavern No. 1 - Bayou Choctaw Dome . . . . . . . . 24

8 Profile - Cavern No. 3 - Bayou Choctaw Dome . . . . . 25

9 Cavern No. 3 - Bayou Choctaw Dome . . . . . . . 26

10 Profile - Cavern No. 8A - Bayou Choctaw Dome . . . . 27

11 Cavern No. 8A - Bayou Choctaw Dome . . . . . . . 28

12 Profile - Cavern No. 11 - Bayou Choctaw Dome . . . . . 29

13 Cavern No. 11 - Bayou Choctaw Dome . . . . . . . 30

14 Profile - Cavern No. 13 - Bayou Choctaw Dome . . . . . 31

15 Cavern No. 13 - Bayou Choctaw Dome . . . . . . . 32

16 Profile - Cavern No. 15 - Bayou Choctaw Dome . . . . . 33

17 Cavern No. 15 - Bayou Choctaw Dome . . . . . . . . 34

18 Profile - Cavern No. 16 - Bayou Choctaw Dome . . . . . 35

19 Cavern No. 16 - Bayou Choctaw Dome . . . . . . . 36

20 Profile - Cavern No. 17 - Bayou Choctaw Dome . . . . 37

21 Profile - Cavern No. 18 - Bayou Choctaw Dome . . . . . 38

22 Cavern No. 18 - Bayou Choctaw Dome . . . . . . . . 39

23 Profile - Cavern No. 19 - Bayou Choctaw Dome . . . . . . 40

24 Cavern No. 19 - Bayou Choctaw Dome . . . . . . . 41

25 Profile - Cavern No. 20 - Bayou Choctaw Dome . . . . . 42

26 Cavern No. 20 - Bayou Choctaw Dome . . . . . . . 43

\section{TABLES}

1 Marine Evaporite Deposits of the United States . . . 5

2 Cavern Data - Bayou Choctaw . . . . . . . . 22 


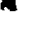


SOLUTION MINING IN SALT DOMES

OF THE GULF COAST EMBAYMENT

\section{INTRODUCTION}

Pacific Northwest Laboratory (PNL) let Subcontract No. B-70746-A-H to the Tecolote Corporation on March 22, 1979. The scope of work given to Tecolote was to provide qualitative and quantitative information that describes the probable impact of solution mining on the release scenarios compiled by PNL. While not specifically stated, solution mining refers to those operations conducted in salt, particularly dome salt, as opposed to bedded salt.

Personnel within the Tecolote Corporation have gained an in-depth knowledge of solution mining operations in dome salt from work associated with the Department of Energy Strategic Petroleum Reserve (SPR) project now under way on the Gulf Coast. Hence, much of the discussion and data presented in this report draws heavily on technical reports related to the SPR project. However, the discussion attempts to give an overview of solution mining (or "brining", as it is also called) as it has been conducted by the chemical industry for feedstock, and the petroleum industry for refined liquid petroleum storage.

Radioactive waste storage requires consideration of post-closure events that may occur in multiples of thousands of years. Some discussion has been included as to availability of salt resources. The essential conclusion drawn is that while salt deposits are vast, dome salt in the Gulf Coast Embayment will be in demand, and retention of a dome virgin to man's exploitation beyond 1000 years will rely on continuance of administrative control. In that the EPA requirements assume loss of such control in 100 years, there is a high probability for a release related to solution mining. The details of the mechanics of such a breach are discussed, but not the consequence of the event. The latter depends on the character and concentration of the radioactive waste; subjects beyond the scope of this report.

The writer extensively used the published reports of others. References acknowledge these contributions. In addition, an Appendix has been added which 
includes two summary discussions of solution mining. They are appended because they are excellent technical reviews but are not readily available in standard libraries.

Background interviews were held with a variety of federal and state agencies plus two industrial trade organizations. The purpose of these discussions was to develop information concerning current brining operations being conducted in the United States along with salt and chlorine market information. 


\section{SALT RESOURCES}

There are vast quantities of rock salt in the United States. However, the majority of the resource is as bedded salt rather than in domes. The locations of bedded deposits in the continental United States are shown in Figure 1 , and the general characteristics of the major formation are given in Table 1.

Dome salt is restricted to the Gulf Coast Embayment which includes southern Arkansas, Mississippi, Alabama, eastern and southern Texas and Louisiana, (See Figure 2). There are more than 300 known salt domes in this area. Salt piercement structures are also known in the Paradox Basin of southwestern Colorado and southeastern Utah; however, the bulk of the salt is contained in broad anticlines rather than as the circular pipelike structures common in the Gulf Coast Embayment.

The United States Bureau of Mines has compiled an excellent summary of 329 known salt domes in the Gulf Coast Embayment (Hawkins and Jirik, 1966). As of 1965, mining or storage operations were being operated in 48 of the domes:

\begin{tabular}{|c|c|}
\hline Conventional mines only & 3 domes \\
\hline Conventional and solution mining & 5 domes \\
\hline Solution mining only & 16 \\
\hline LPG storage & \\
\hline
\end{tabular}

The Bureau of Mines estimated that 130 of the 329 domes in the Gulf Coast Embayment offer potential for mining, brining and/or creation of underground storage. In other words, 82 domes await exploitation by man.

\section{PRODUCTION OF ROCK SALT AND BRINE FROM SALT DOMES}

The United States produced a total of 43.7 million tons of salt in 1978. Louisiana and Texas accounted for $55.5 \%$ of this production, all of which came from salt domes. Salt produced in Texas and Louisiana is divided approximately $75 \%$ produced from we $1 \mathrm{ls}$ and brine and $25 \%$ as rock salt by conventional mining. The end use of the brine is to make chlorine-based chemicals with a minor 


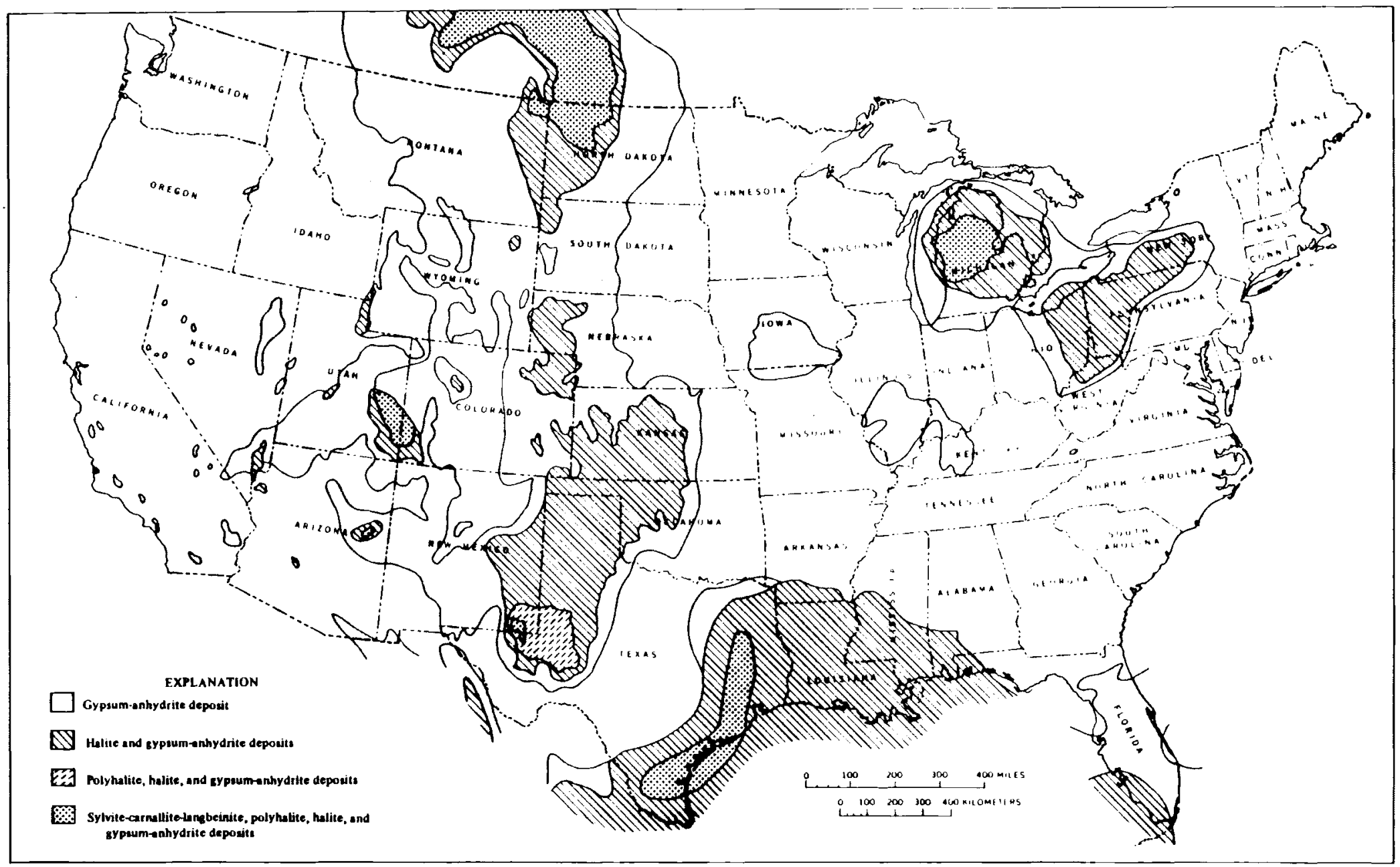

FIGURE 1. Marine Evaporite Deposits of the United States

Source: Mineral Resources of the United States, U.S. Geol. Surv. Prof. Paper 820, 1973. 


\section{TABLE 1. Marine Evaporite Deposits of the United States (U.S. Geological Survey Prof Paper 820)}

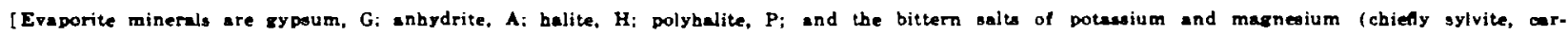
nallite, and langbeinite). S. Thieknesses are approximate and inelude nonevaporite rocks ]

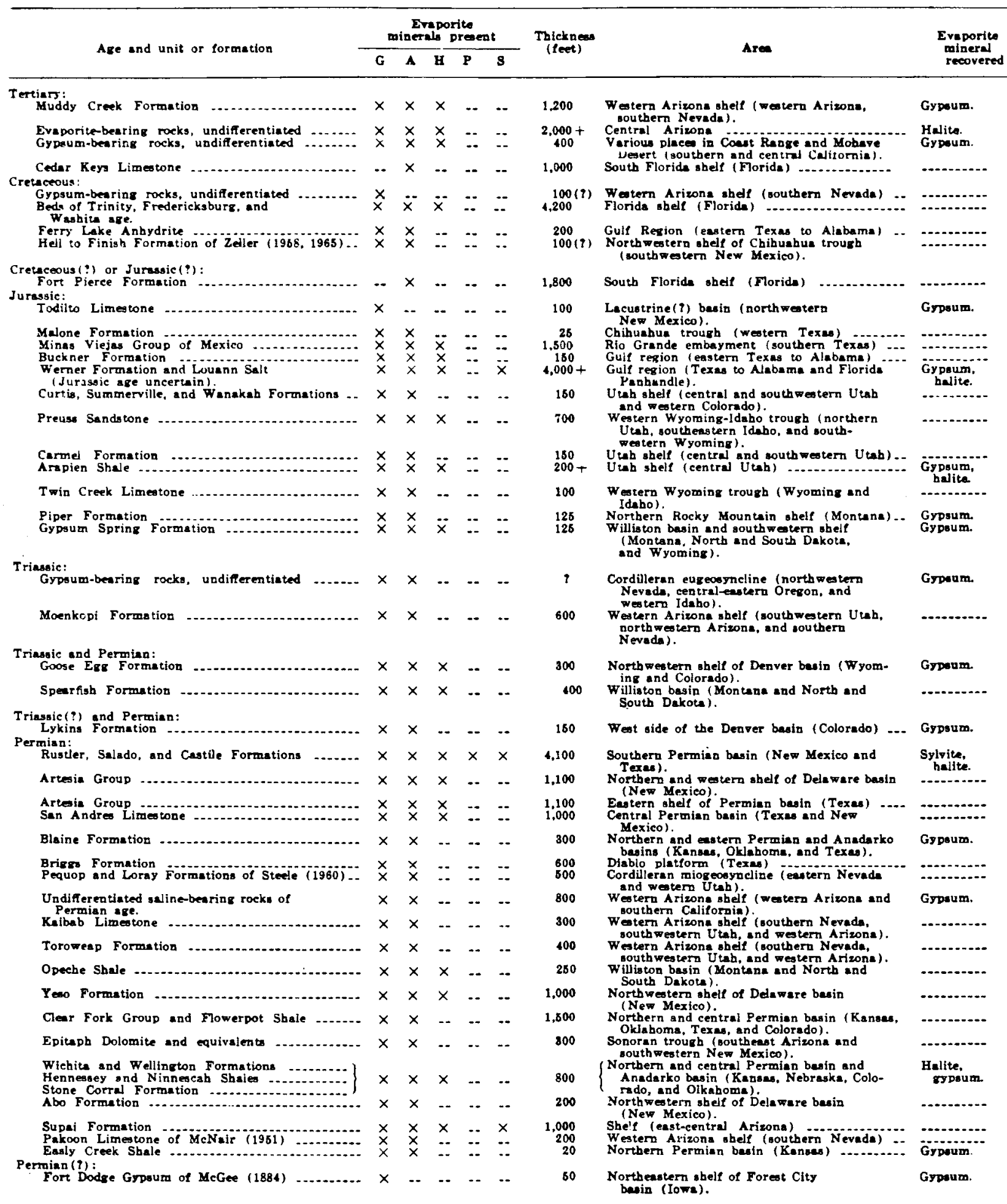




\section{Table 1 (continued)}

\begin{tabular}{|c|c|c|c|c|c|c|c|c|}
\hline \multirow{2}{*}{ Age and unit or formation } & \multicolumn{5}{|c|}{$\begin{array}{l}\text { Evaporite } \\
\text { minetais present }\end{array}$} & \multirow{2}{*}{$\begin{array}{l}\text { Thickness } \\
\text { (feet) }\end{array}$} & \multirow{2}{*}{ Are } & \multirow{2}{*}{$\begin{array}{l}\text { Evaporite } \\
\text { mineral } \\
\text { recovered }\end{array}$} \\
\hline & $\mathbf{G}$ & $\mathbf{A}$ & $\mathbf{H}$ & $\mathbf{P}$ & $\mathbf{s}$ & & & \\
\hline $\begin{array}{l}\text { Perminn and Pennoylvanian: } \\
\text { Mindelusa Formation }\end{array}$ & $x$ & $x$ & $x$ & $-\cdot$ & -- & 480 & $\begin{array}{l}\text { Denver and Williston basins (Colorado, } \\
\text { Nebraska, North and South Dakota, } \\
\text { and Montana). }\end{array}$ & - concon \\
\hline $\begin{array}{l}\text { Wells Formation } \\
\text { Panther Seep Formation } \\
\text { Pennsyivanian: }\end{array}$ & $\bar{x}$ & $\stackrel{x}{x}$ & -- & $\because-$ & $\ddot{--}$ & $\begin{array}{l}100 \\
100\end{array}$ & $\begin{array}{l}\text { Southeastern Idaho and northern Utab } \\
\text { Oro Grande basin (southern New Mexico) }\end{array}$ & (n) \\
\hline Hermose Formation & $x$ & $x$ & $x$ & $\cdots$ & $x$ & 5,000 & Paradox basin (Colorado and Utah) & $\begin{array}{l}\text { Sylvite, } \\
\text { balite. }\end{array}$ \\
\hline $\begin{array}{l}\text { Eagle Valley Evaporite } \\
\text { Misaisoippian or younger: } \\
\text { Gypan-bearing rocks, undjferentiated } \\
\text { Mississippian: }\end{array}$ & $\begin{array}{l}\times \\
\times\end{array}$ & $\begin{array}{l}x \\
\times\end{array}$ & $x$ & $-\cdot$ & $x$ & $\begin{array}{l}1,000 \\
50(1)\end{array}$ & $\begin{array}{l}\text { Eagle basin (western Colorado) } \\
\text { Cordilleran eugeosyncline (Chichagof Lsland, } \\
\text { Alacka). }\end{array}$ & - n \\
\hline $\begin{array}{l}\text { Mississippian: } \\
\text { Big Snowy Group (of pormation rank in } \mathrm{SW} \\
\text { Montana and Idabo). } \\
\text { Otter Formation }\end{array}$ & $\begin{array}{l}\times \\
\times\end{array}$ & $\begin{array}{l}x \\
\times\end{array}$ & -- & - & $\cdots$ & 50 & $\begin{array}{l}\text { Northern Rocky Mountain shelf (Montana, } \\
\text { Idaho, and Wyoming). } \\
\text { Williston basin and Northern Rocky Moun. } \\
\text { cain shelf (Montana and North and Soutb } \\
\text { Dakota). }\end{array}$ & (n) \\
\hline Kibbey Formation & $x$ & $x$ & -- &.- & -- & 200 & $\begin{array}{l}\text { Willision basin and Northern Rocky Moun- } \\
\text { tain shelf (Moneans and North and South } \\
\text { Dakota). }\end{array}$ & 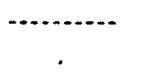 \\
\hline Charles Formation & -- & $x$ & $\times$ & $-\infty$ & -- & 800 & $\begin{array}{l}\text { Williston basin and Northern Rocky Moun- } \\
\text { tain ahelf (Montana and North and South } \\
\text { Dakota). }\end{array}$ & $\ldots$ \\
\hline Warsew and St. Louis Limestones & $x$ & $x$ & -- & -- & - & 128 & $\begin{array}{l}\text { Northessiern shelf of Forest City basin } \\
\text { (lowa). }\end{array}$ & Grouum. \\
\hline St. Louis Limestone & $x$ & $x$ & - & $\cdots$ & $\cdots$ & 200 & $\begin{array}{l}\text { Mlinois basin (Indiana, Illinois, and } \\
\text { Kentucky). }\end{array}$ & Do. \\
\hline Macerady Shale & $x$ & $x$ & $x$ & -- & $\cdots$ & $250(?)$ & Appalachian basin (Virginia) & $\begin{array}{l}\text { Gypanm. } \\
\text { halite. }\end{array}$ \\
\hline $\begin{array}{c}\text { Micbigan Formation } \\
\text { evonian: }\end{array}$ & $x$ & $x$ & -- & -. & $\cdots$ & 460 & Michigan basin (Michizan) & Gypsum. \\
\hline $\begin{array}{l}\text { Three Forks Formation and Potlatch Anhydrite. } \\
\text { Souris River Formation }\end{array}$ & 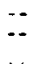 & $\begin{array}{l}x \\
x\end{array}$ & -- & -- & $\begin{array}{ll}-- \\
--\end{array}$ & $\begin{array}{l}680 \\
200\end{array}$ & $\begin{array}{l}\text { Nortbern Rocky Mountain shelf (Montana).. } \\
\text { Williston basin (Montsna and North and } \\
\text { South Dakota). }\end{array}$ & (n) \\
\hline Cedar Valley and Wapsipinicon Limedones ...... & $x$ & $x$ & $x$ & -. & $x$ & 600 & $\begin{array}{l}\text { Williston basin (Montana and North and } \\
\text { South Dakota). }\end{array}$ & $\begin{array}{l}\text { (Malive nd } \\
\text { sylvite re- } \\
\text { corered in } \\
\text { Censdimn } \\
\text { aection of } \\
\text { basin). } \\
\text { Gypsum. }\end{array}$ \\
\hline $\begin{array}{l}\text { Detroit River Group (of formation rank in } \\
\text { Indiane according to Shaver and others, 1970). } \\
\text { ilurien: }\end{array}$ & $x$ & $x$ & $x$ & $\cdots$ & -- & 1,100 & $\begin{array}{l}\text { Michigan basin (Michigan, Obio, and } \\
\text { Indiana). }\end{array}$ & Halite. \\
\hline Saline Formation & $x$ & $x$ & $\times$ & -- & $x$ & 4,000 & $\begin{array}{l}\text { Appalachian and Michigan basing (New } \\
\text { York, Pennsylvania, West Virginia, } \\
\text { Ohio, and Michigan). }\end{array}$ & $\begin{array}{l}\text { Gypsum, } \\
\text { halite }\end{array}$ \\
\hline $\begin{array}{l}\text { Interlake Form } \\
\text { Ordovicien: }\end{array}$ & -- & $x$ & - & -- & $\cdots$ & 80 & $\begin{array}{l}\text { Williaton basin (Montana and North and } \\
\text { South Dakota). }\end{array}$ & (n.............. \\
\hline $\begin{array}{l}\text { Ordovician: } \\
\text { Red River, Stony Mountain, and Stonewall of } \\
\text { Kindle (1914) Formations. } \\
\text { Joachim Dolomite equivalent } \\
\text { Precambrian: }\end{array}$ & $\cdots$ & $\begin{array}{l}x \\
\times\end{array}$ & $\cdots$ & $\ddot{--}$ & 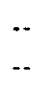 & $\begin{array}{r}200 \\
85\end{array}$ & $\begin{array}{l}\text { Williston bagin (Montana and North and } \\
\text { Soutb Dakota) } \\
\text { Illinois besin (Illinois) }\end{array}$ & - n- \\
\hline 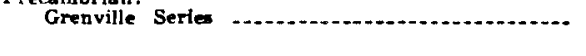 & $x$ & $x$ & -- & -. & -- & 200 & $\begin{array}{l}\text { Northwestern Adirondack Mountains (New - } \\
\text { York). }\end{array}$ & (2............... \\
\hline
\end{tabular}




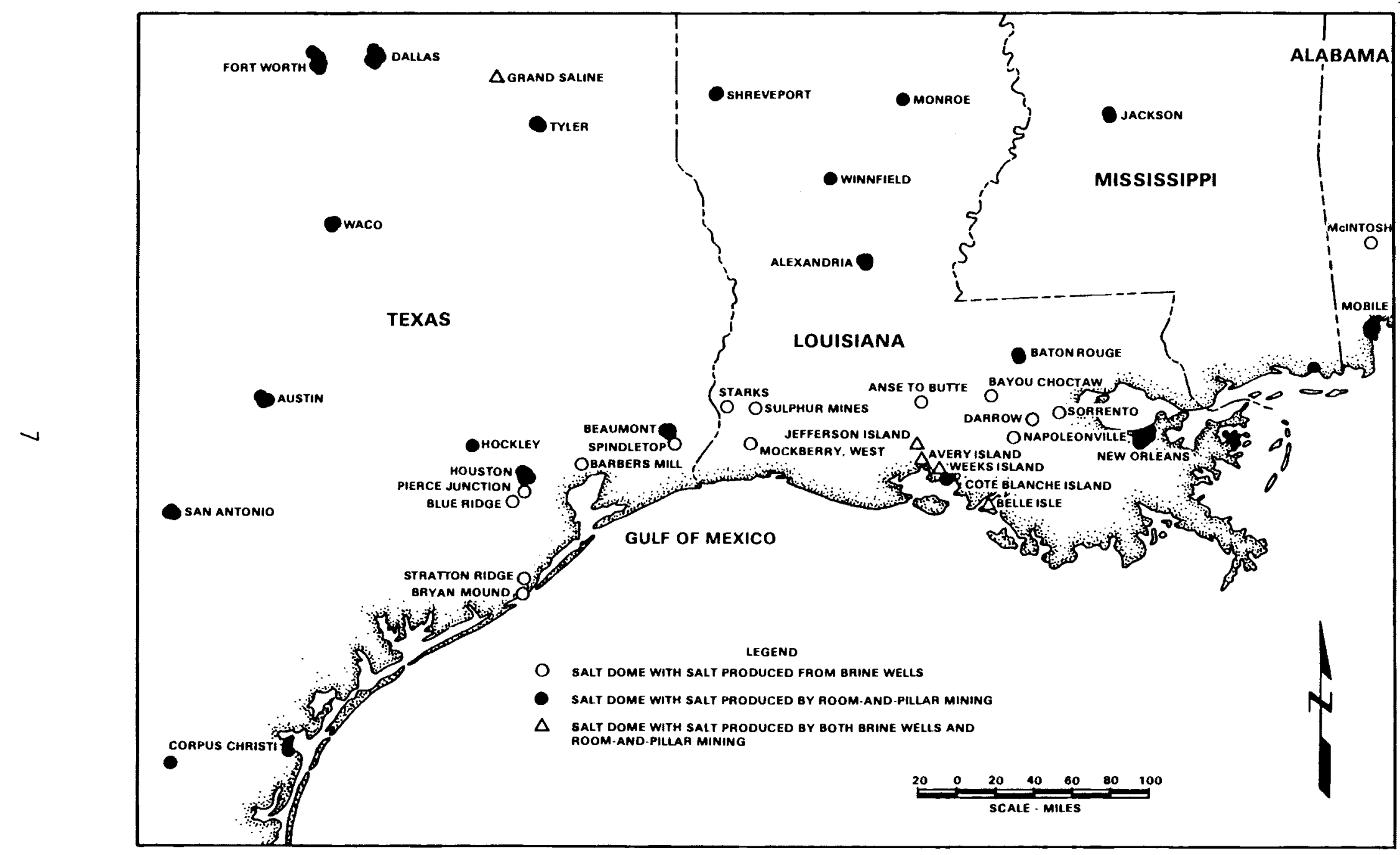

FIGURE 2. Location of Domes in the Gulf Coast Embayment

Source: U.S. Bureau of Mines, Infor. Circ. 8313, 1966. 
amount being used for table salt production; while the conventionally mined "rock salt" goes to a variety of uses, of which, road de-icing is the largest single use. The location of the principal operations are shown in Figure 3.

The market forecast for salt calls for a steady but modest increase in production. Similarly, little change is forecast in the extraction technology or ratio between conventional and solution mining.

At present there are some 900 underground caverns in use for LPG storage in the United States, with a combined storage volume of 300 million barrels (1.68 billion cubic feet). About half of that capacity is located in the Gulf Coast Embayment. New underground storage for liquid petroleum is expected to increase dramatically during the next decade. The Strategic Petroleum Reserve may require 750 million barrels ( 4.21 billion cubic feet) alone. However, by the year 2000 it is expected that enough underground storage will have been created to accommodate the need for such storage. The exact volume has not been forecast for the next decade or two, but it should be on the order of more than 5 billion barrels but less than 10 billion barrels. It is reasonable to assume that domes in the Gulf Coast Embayment will provide $50 \%$ of the new capacity.

ESTIMATE OF THE TIME WHEN THE UNITED STATES WILL HAVE EXPLOITED MOST SALT DOMES IN THE GULF COAST EMBAYMENT

The United States Bureau of Mines estimated that the domes in the Gulf Coast Embayment could supply the U.S. needs for 26,000 years. (Hawkins and Jirik 1966, p. 14). However, that assumption assumed that the salt could be exploited to a depth of two miles. Conventional mining is rarely conducted more than 3000 feet below ground level because it is the point where plastic flow becomes pronounced. Underground storage or brining operations are seldom conducted below 5000 feet because of excessive pumping costs.

It is worthy of making a back-of-the-envelope calculation of the time when most of the subject domes will have been "consumed." 


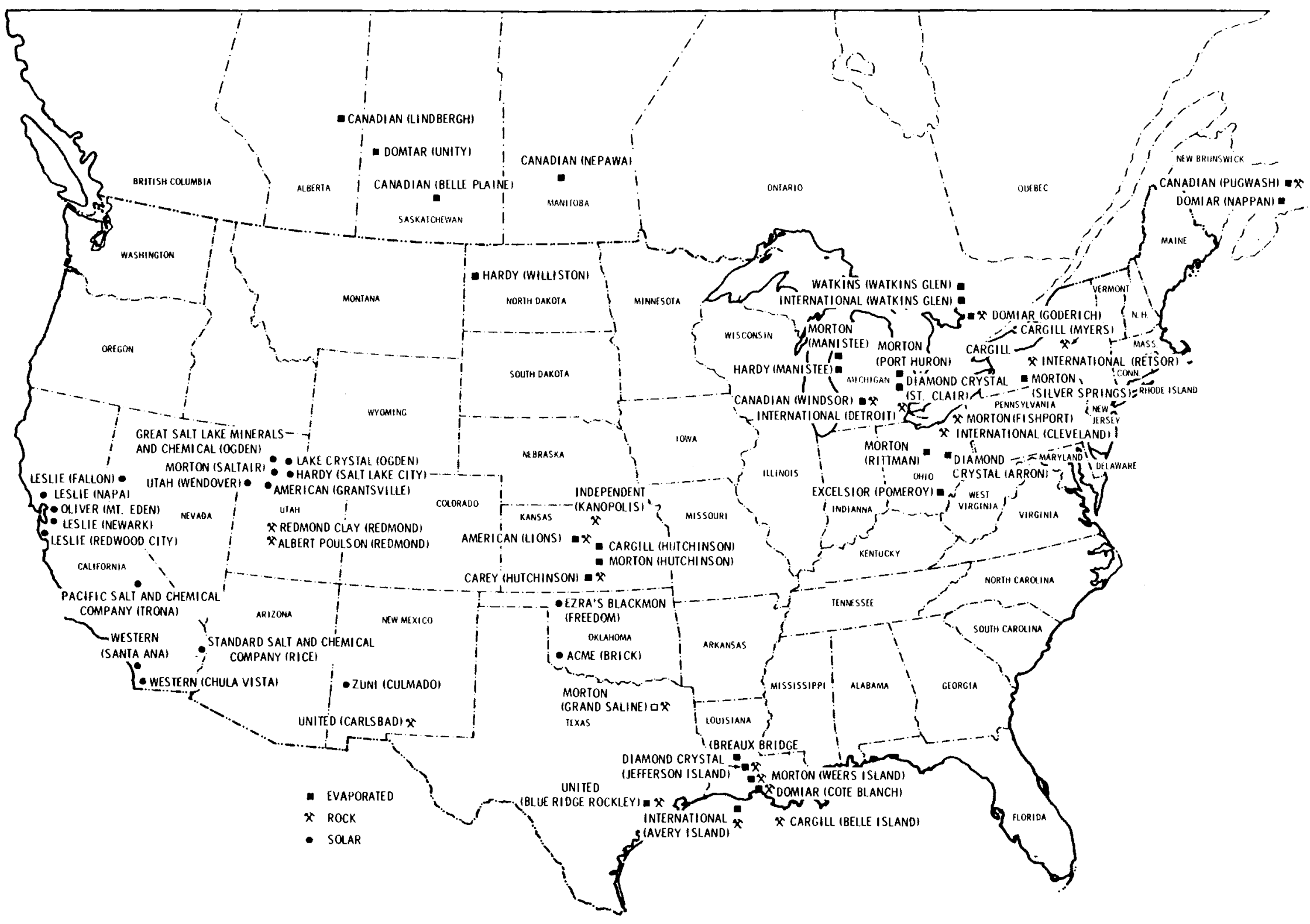

FIGURE 3. Dry Salt Production Sites United States and Canada. Source: Salt Institute 
Assumptions

1. Total Domes

Useful Domes

Domes Now in Use

Net for Future Use
329

120

$\frac{48}{82}$

82

2. Average Conventional Mine

Two levels, $50 \%$ total extraction in plan

Each mining level 100 feet high

Net tons per square mile $=186$ million

3. Average Storage or Brine Cavern Operation

Single level, $10 \%$ total extraction in plan

1000 feet high cavities

Net tons salt per square mile $=186$ million

4. Average Mining Rates

Conventional, al1 future time $2 \times$ Present $=12 \mathrm{million}$ tons $/ \mathrm{yr}$

Brine Mines, all future time $3 \times$ Present $=55$ million tons $/ \mathrm{yr}$

Underground Storage

$\begin{array}{ll}\text { Next } 20 \text { yrs } & 250 \text { million barrels per year } \\ & =94 \text { million tons salt per year } \\ \text { Thereafter } & 20 \text { million barrels per year } \\ & =7.5 \text { million tons salt per year }\end{array}$

5. Average Dome Size

Plan Area

Net Usable Area

\section{Calculations}

Domes Consumed in Next 20 Years

Total tons mined in next 20 years:

Conventional

Brining

Storage
3 square miles

2 square miles
Bureau of Mines Study

Bureau of Mines Study

Bureau of Mines Study 
Total Plan Area "Consumed"

3.22 billion tons $\div 186 \mathrm{million}$ tons $/ \mathrm{sq} \mathrm{mi}=17.3 \mathrm{sq} \mathrm{mi}$

Domes "Consumed" $=17.3 \mathrm{sq} \mathrm{mi} \div 2 \mathrm{sq} \mathrm{mi} /$ dome $=8.66$ comes

Annual Consumption of Domes After Year 2000

Total tons mined per year:

Conventional 12 million tons

Brining

55 million tons

Storage

7.5 million tons

74.5 million tons

Total Plan Area "Consumed" Per Year

$74.5 \mathrm{million}$ tons $\div 186 \mathrm{million}$ tons $/ \mathrm{sq} \mathrm{mi}=0.40 \mathrm{sq} \mathrm{mi} /$ year

Consumed Per Year After Year 2000

$0.4 \mathrm{sq} \mathrm{mi} \div 2 \mathrm{sq} \mathrm{mi} /$ dome $=0.20$ domes/year, or 73 domes in 365 years Time of "Extinction" of Gulf Coast Domes

$\begin{array}{lr}\text { Domes Available Now } & 82 \\ \text { Domes Used by Year 2000 } & 9 \\ \text { Domes Used in the Next 365 yrs } & \underline{73} \\ \text { thereafter } & \\ \text { Domes Remaining in Year 2365 = } & 0\end{array}$

Significance of Salt Resources to the Waste Isolation Safety Assessment

Therefore, we conclude that the supply of virgin salt domes suitable for underground storage, brining or rock salt mining will be exhausted by the year 2365 or 385 years from now. The number is almost two orders of magnitude smaller than the Bureau of Mines' estimate of 26,000 years. The reduction was caused by: (1) Reducing the minable height (net 100 feet for both conventional and solution mining) versus one mile by the Bureau, (2) Assuming that future requirements for salt will steadily increase, and (3) Including liquid storage projects. The calculations given by us should be considered a "worst case", but it is difficult to forecast that virgin domes stil1 will exist beyond another 1000 years. 


\section{DESCRIPTION OF CONVENTIONAL MINING}

\section{MINING PRACTICES}

To a mining engineer, salt is an ideal medium to excavate. It is relatively soft, but cohesive and of reasonable strength. He can mine large chambers without the need for support. The large rooms are beneficial because ventilation is excellent and permits the use of large machinery. Productivity, measured in tons per man shaft, exceeds 100 in many mines.

The mining method used is called room and pillar which consists of mining chambers in regular rectangular patterns that create square abutments called pillars. Mining chambers have a typical dimension of 50 feet wide $\times 90$ feet high. In the active mining areas, as much as $65 \%$ to $80 \%$ of the salt is extracted in plan. However, large pillars are left around the shafts and main entry ways so that overall extraction within the mine complex is about $50 \%$ in plan. Once one area is mined out, it is common to recommence mining on a level below the first. No standards have been set for the thickness of the solid pillar left to separate the two levels, but a rule of thumb is that it be twice the mining height. Theoretically, one could develop many more levels, but the cost of hoisting, ventilation, salt formation temperature, and increasing plastic deformation limit mining to depths less than 3000 feet below the surface. The deepest mine in the Gulf Coast Embayment is 1500 feet deep.

\section{MINE SAFETY}

Salt mining is considered very safe in comparison to other types of underground mining. Fatalities are rare and tend to be associated with the motion of the heavy equipment or accidental electrocution versus roof falls which is the main killer in other underground mines.

However, salt mines are not free from disasters. Of the eight mines developed in Texas and Louisiana salt domes, one is now abandoned. The mine was called Winfield and was located in northern Louisiana. No loss of life occurred, but an inrush of water completely flooded the mine 15 years ago. Apparently a fissure or water course extended from the water saturated 
"caprock" into the interior of the dome. The worst accident with fatalities involved occurred at the Belle Isle Mine in southern Louisiana. In 1968, 21 men died due to a fire in the shaft. Then in June 1979, 5 men died from a methane gas explosion at the same mine.

\section{SIGNIFICANCE TO WASTE ISOLATION SAFETY ASSESSMENT}

The eight conventional mines in the Gulf Coast Embayment have a combined operating history of 407 "mine years" through 1979. One mine has been lost due to flooding during this period.

Therefore, in the future we should be willing to accept these facts:

1. Mines will occasionally be flooded.

2. Seven mines are now operating.

3. Rock salt will continue to be in demand and the number of mines may increase to ten.

4. New mines will be located in virgin domes as the existing reserves are depleted at present locations.

5. We assume:

a. Ten mines will be required for future supply.

b. A single mine is located in any particular dome.

c. Based on past experience, the chances are that a single mine flooding will occur every 407 "mine years" of operation.

d. The operating life for complete exploitation of a dome having two square miles of area is:

Mine Life $=\frac{186 \mathrm{million} \text { tons } / \mathrm{sq} \mathrm{mi} \times 2 \mathrm{sq} \mathrm{mi}}{1.2 \mathrm{mi} 11 \text { ion tons } / \text { year }}=310$ years

e. Hence, the probability that a mine become flooded approaches unity. Probability $=310 \div 407=0.76$.

6. No consideration has been given to the method of decommissioning a salt mine, and that eventual failure of seals will cause flooding. 


\section{SOLUTION MINING}

GENERAL COMMENTS

No exact date is known when solution mining of salt commenced. We do know that salt springs were used to supply the tanners' needs soon after the entrance of the French into the Louisiana River area in the later 1700's. No doubt the Indians showed them these resources, so we must push back the time of use of brines in the Gulf coast Embayment to the arrival of the first American.

Salt domes were first considered as repositories for Liquified Petroleum Gas (LPG) in the late 1940's. The first facility was in operation by 1951. Cavities in salt have been solution mined on an increasing scale until there are some 900 cavities having a total capacity of 300 million barrels today. Approximately half that capacity is in domes. Plans are underway to create a vast amount of new storage capacity to accommodate the Strategic Petroleum Reserve and "compressed air storage" to alleviate peak power demands. In these cases the storage is considered to be "live", i.e., to be periodically recovered. However, proposals to use cavities in salt as permanent disposal sites for industrial toxic wastes are now being considered. The last entry into utilization of salt domes will be for radioactive waste isolation.

\section{MINING PRACTICES}

The concept is quite simple. Salt is soluble to fresh water, and all one needs to do to start solution mining is to establish a circulating system to wash the salt and recover the brine. Under actual conditions, the operation is a bit complex. Large diameter wells are needed to accommodate the required flow capacity and to reduce friction losses related to pumping. The costs of well drilling and casing costs are high into salt domes because of highly permeable and fractured "caprock" that overlies the salt. Other complicating problems are disposal of the brine whether it be after it has passed through a chemical plant or raw brine if the solutioning is done solely to provide underground storage space. Offshore pipeline disposal is the preferred method, 
but when not feasible waste water disposal wells must be drilled. A brief description of solution mining follows. For full details on the state of the art of this process the reader is referred to Appendix $A$ and $B$.

BRINING TO PRODUCE SALT WATER VERSUS SOLUTION MINING FOR THE CREATION OF STORAGE CAPACITY

The difference is rather subtle. Brining is a word normally used to describe those operations where the sought after product is salt water for use as feed stock to chlorine plants. On the other hand, solution mining is a better set of words to use to describe those operations where the objective is to provide an underground chamber for storage of products. In the case of brining, the essential design parameter is to minimize pumping and maximize salt production. Solution mining of storage facilities has the additional design parameters of controlling cavern shape and insuring the eventual underground vessel is hydraulically tight. In both operations, cavern stability is important but not to the same degree. In brining operations a cavern collapse is a disturbing event. The collapse of a storage cavern is a disaster.

\section{TECHNICAL DESCRIPTION OF SOLUTION MINING}

Drilling

The essentials of the system used for a storage cavern are shown in Figure 4. A large diameter hole ( $\sim 30$ inches) is drilled through the caprock into the top of the salt. Casing is run and cemented to the surface. Normally the casing size will be $\sim 20$-inch diameter, but may be smaller if drilling problems have necessitated setting of intermediate strings of casing. The hole is then advanced downward into the salt to the point where the top of the desired cavern will be formed. In brining operations this may be only 100 feet into the salt, but for storage caverns the preferred distance is more than 500 feet. At this point, another string of casing is run and cemented back to the surface. The final drilling operation is open hole to the bottom of the planned cavern. 


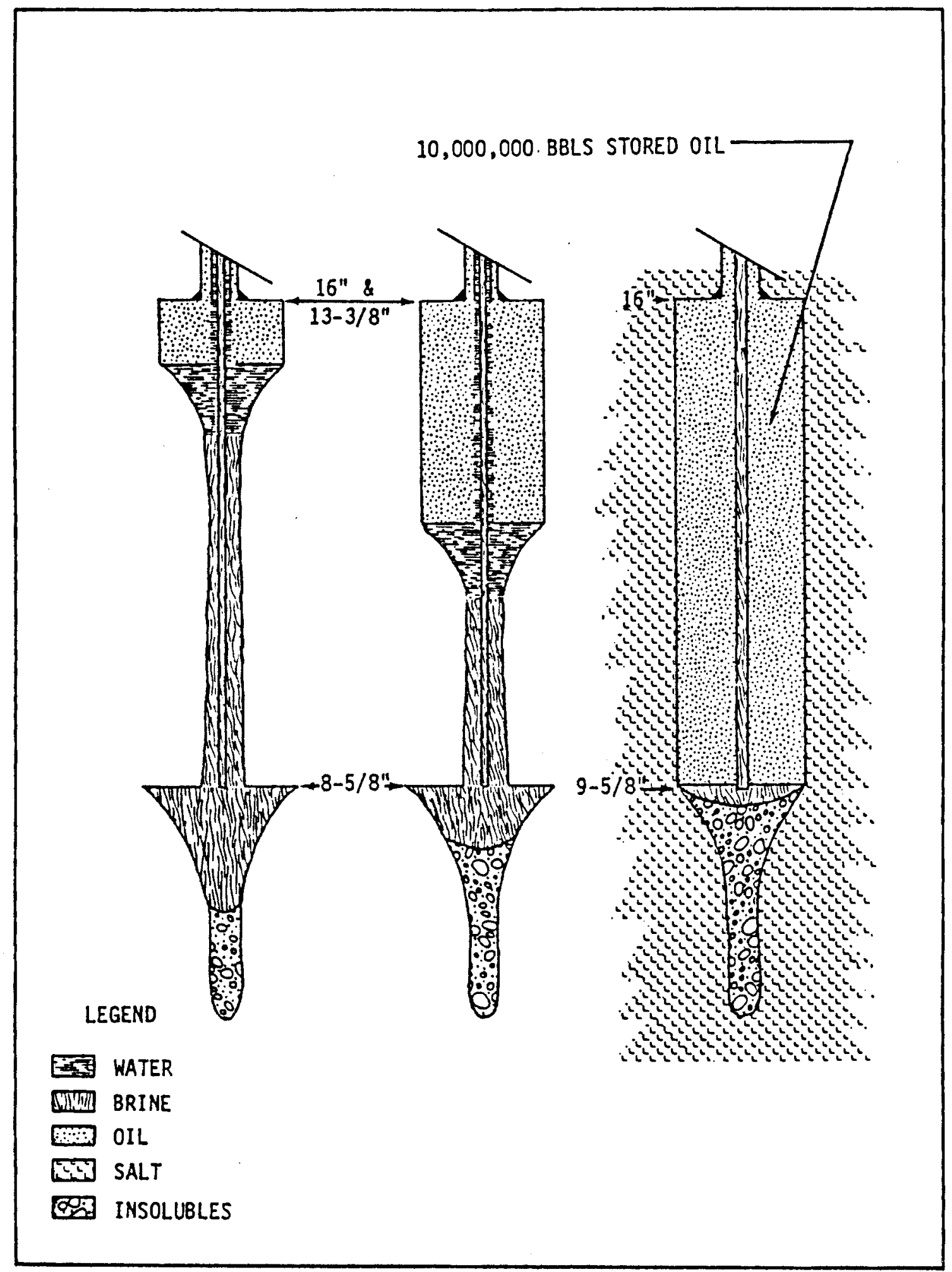

FIGURE 4. Alternate Concept for Concurrent Leaching and Storage Source: Fenix and Scisson 1976 


\section{Sump Development}

The dome salt is not pure, and approximately $2 \%$ to $5 \%$ of insoluble anhydrite and clay are distributed evenly in the salt. 0ccasionally large blocks of insoluble material also are present. These factors dictate that a small pocket or sump be formed at the base of the desired final cavern. This operation is done by: (1) passing a blanket casing string down to the top of the sump, (2) running a tubing string inside the blanket casing, and (3) displacing oil into the annulus between the rock wall and the blanket casing. Direct circulation is used whereby fresh water is pumped down the tubing and removed by passing back upward through the annulus between the tubing and the rock walls and then up into the blanket casing. The volume of the sump is normally $5 \%$ of the eventual volume of the design cavern.

\section{Formation of the Cavern Roof}

The next step in solution mining is to move the blanket casing and tubing strings back up hole to a point just below the last cemented casing. 0il is again placed in the annulus between the cemented and blanket casing strings. Direct circulation is commenced. The better operators attempt to form a dome shape cavern top. This is accomplished by gradually injecting additional oil down the cement-blanket string annulus thus forcing solutioning to move downward and outward. The success of this operation depends mostly on the art of the operators.

\section{Main Cavern Formation}

Once the sump has formed and a stable roof formed, the main washing commences. Normal practice is to maintain direct circulation, working from the top downward. This requires periodic lowering of the blanket and tubing strings along with continual depression of the oil blanket.

\section{Cavern Shape Control}

The basin control is the oil blanket along with continual adjustment of the blanket and tubing strings. Pumping rate is a third variable. Experience has indicated that no two caverns ever wash the same and there is no set procedure. At times reverse circulation is used to adjust cavern shape. The 
only tool available to define cavity shape and size is the "sonar caliper". The device works on the principle of focused acoustic signals reflecting from the cavern walls. Most modern LPG storage caverns have a height to diameter ratio of $5: 1$ or more.

TECHNICAL DESCRIPTION OF BRINING OPERATIONS

Well design is essentially the same. However, cavern shape control is not of major concern other than to prevent cavern collapse. Quite often the entire open hole section is washed once the cavern top has been formed. Brining operations cannot economically justify large oil blankets. Both direct and reverse circulation are used. Sonar caliper surveys are run periodically to assist in determining any abnormal cavern development. Injection rates and tubing position are adjusted to correct cavern growth.

The shape of brining caverns is much better controlled today than it was in the past. Resurvey of old caverns by the sonar caliper has revealed such a variety of shapes that they can only be described as being as variable as ink blots. Seldom are they cylindrical but rather have a height to diameter ratio of 1:1. Brine caverns are also large in comparison to storage caverns. Brine caverns are as large as 50 million barrels with 10 million barrels about the norm. On the other hand, LPG caverns seldom exceed 1 million barrels, albeit the SPR project designs call for $10 \mathrm{million}$ barrel caverns.

\section{DATA CONCERNING CAVERN SHAPE AND VOLUME}

Brining operations started on a large-scale in the early $1900^{\prime} s$. LPG storage started in 1951. The exact number of caverns, both brine and storage, is not available to us, but we estimate it to be on the order of 500 in the Gulf Coast Embayment. During the initial planning of the SPR project some 154 "facilities" were screened resulting in selecting 20 domes as potentially suitable for crude oil storage in existing caverns. This study, conducted by Fenix and Scisson, Inc. under contract to Federal Energy Administration (FEA), is the most detailed geotechnical survey of existing caverns known to us. See annotated references, Fenix and Scisson, Project II, 1976. Much of the data presented below was taken from that study. 


\section{Case Example}

Bayou Choctaw, a dome located near Baton Rouge, Louisiana, has been chosen as a case example. The dome is approximately 1 mile in diameter, and the depth to salt is approximately 650 feet. See Figure 5 . A total of 20 caverns exist in this dome divided by type as follows: 15 brine, 3 storage, 2 undeveloped. Brining operations have been underway for more than 30 years. Additional data on 12 brine caverns is given in Table 2. Plan and cross-sections based on sonar caliper surveys for these 12 caverns are shown in Figures 6 to 26 . Please note that only Cavern No. 17 meets the classical type cavern shape shown in much of the literature. Then note the shape of Cavern No. 18, which was the next cavern created after No. 17. The contrast serves to illustrate that cavern geometry is difficult to control.

Other conditions of interest at Bayou Choctaw are:

- The roof of Cavern No. 7 collapsed. The collapse is thought to have been caused by inadvertent washing behind the casing causing the cavern to grow upward into the caprock. A lake has formed around the collapse.

- Caverns No. 3, 11 and 13 are hydraulically connected. The connection was proven by hydraulic pressure testing. In plan, the caverns are separated by at least 200 feet of pillar salt. Sonar surveys are not sufficiently precise to map the connections.

- Caverns No. 4 and 10,have leached upward into the caprock. Eventual collapse may occur.

Recent strengthening of federal and state regulations along with increased expertise in solution mining operations will tend to improve control over cavern formation. However, Bayou Choctaw is a reasonable case history of brining operations as conducted in the past. 


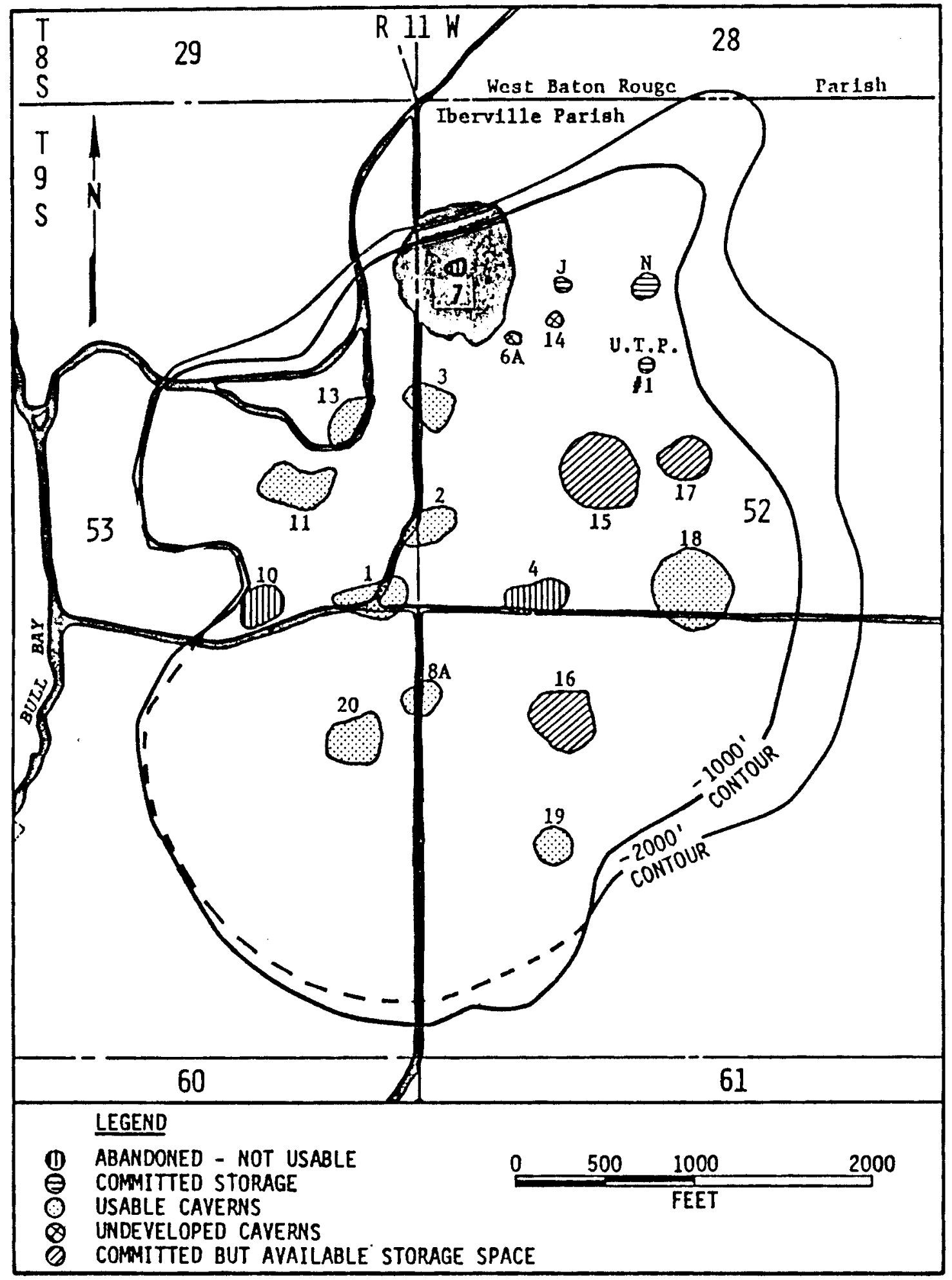

FIGURE 5. Cavern Classification - Bayou Choctaw Source: Fenix and Scisson 1976 
TABLE 2. Cavern Data - Bayou Choctaw

\begin{tabular}{|c|c|c|c|c|c|c|c|c|c|c|}
\hline \multicolumn{2}{|r|}{ Cavern } & $\begin{array}{r}\text { Total } \\
\text { Original } \\
\text { (feet) } \\
\end{array}$ & $\begin{array}{l}\text { epth } \\
\begin{array}{l}\text { Present } \\
\text { (feet) }\end{array}\end{array}$ & $\begin{array}{l}\text { Top of } \\
\text { Cap Rock } \\
\text { (feet) }\end{array}$ & $\begin{array}{l}\text { Top of } \\
\text { Salt } \\
\text { (feet) } \\
\end{array}$ & $\begin{array}{l}\text { Top of } \\
\text { Cavern } \\
\text { (feet) } \\
\end{array}$ & \multicolumn{2}{|c|}{$\begin{array}{l}\text { Product Casing } \\
\text { Size Depth } \\
\text { (inches) (feet) }\end{array}$} & $\begin{array}{l}\text { Maximum } \\
\text { Diameter } \\
\text { (feet) } \\
\end{array}$ & $\begin{array}{l}\text { Height } \\
\text { of Cavern } \\
\text { (feet) }\end{array}$ \\
\hline & 1 & 1,995 & 1,816 & 415 & 653 & 988 & $10-3 / 4$ & 941 & 418 & 828 \\
\hline & 2 & 1,862 & 1,608 & 376 & 639 & 741 & $13-3 / 8$ & 741 & (a) & 867 \\
\hline & 3 & 2,006 & 1,830 & 506 & 660 & 876 & $10-3 / 4$ & 1,008 & 295 & 954 \\
\hline & $8 A$ & 2,007 & 1,978 & 432 & 776 & 1,242 & $10-3 / 4$ & 1,161 & 235 & 736 \\
\hline & 11 & 2,020 & 1,812 & NONE & 704 & 1,067 & $13-3 / 8$ & 951 & 400 & 745 \\
\hline & 13 & 2,030 & 1,883 & 571 & 875 & 1,112 & $13-3 / 8$ & 1,104 & 300 & 771 \\
\hline & 15 & 3,577 & 3,297 & 477 & 637 & 2,597 & $13-3 / 8$ & 2,564 & 480 & 700 \\
\hline & 16 & 3,481 & 3,264 & 659 & 807 & 2,620 & $13-3 / 8$ & 2,583 & 360 & -- \\
\hline & 17 & 4,141 & 4,043 & 454 & 825 & 2,598 & $13-3 / 8$ & 2,572 & 295 & 1,445 \\
\hline & 18 & 4,383 & 4,285 & 430 & 850 & 3,500 & 16 & 1,176 & 480 & 785 \\
\hline & 19 & 4,400 & 4,312 & 550 & 850 & 2,980 & 20 & 1,084 & 415 & 1,332 \\
\hline & 20 & 4,452 & 4,328 & 500 & 681 & 4,126 & 20 & 1,071 & 355 & 202 \\
\hline
\end{tabular}

(a) No Sonar Caliper Survey available. Source: Fenix and Scisson, Inc., 1976 


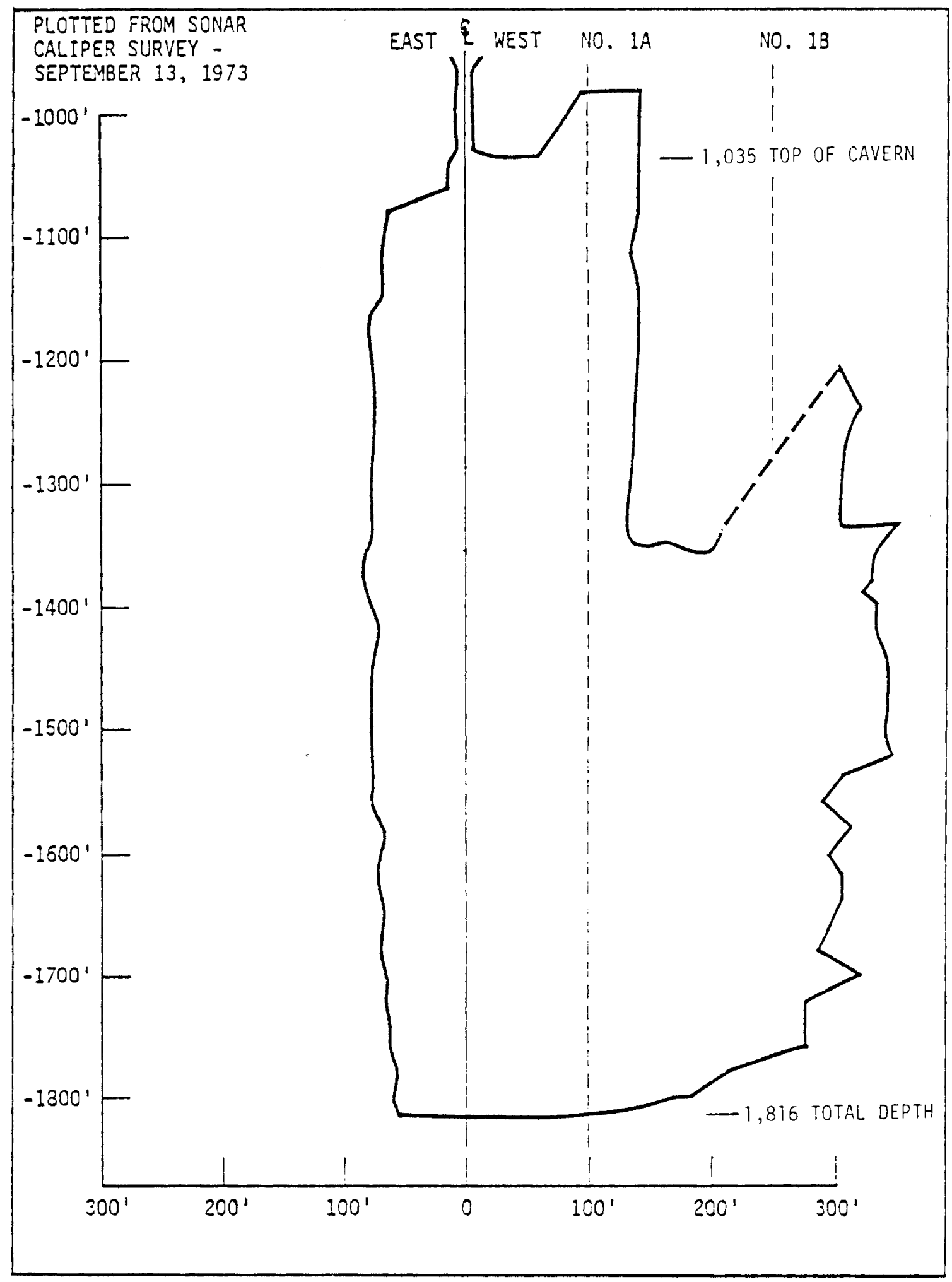

FIGURE 6. Profile - Cavern No. 1 - Bayou Choctaw Dome Source: Fenix and Scisson 1976 


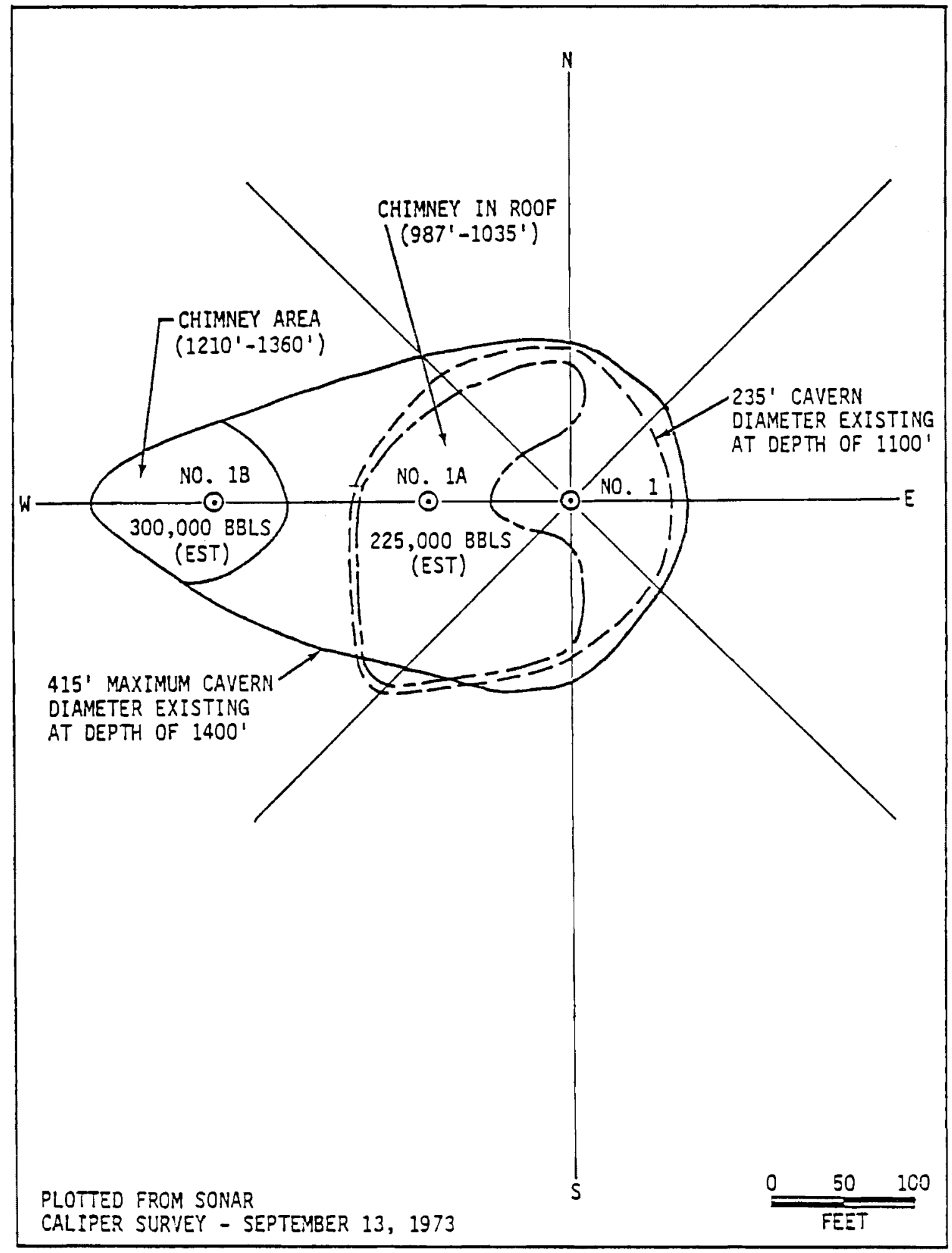

FIGURE 7. Cavern No. 1 - Bayou Choctaw Dome

Source: Fenix and Scisson 1976 


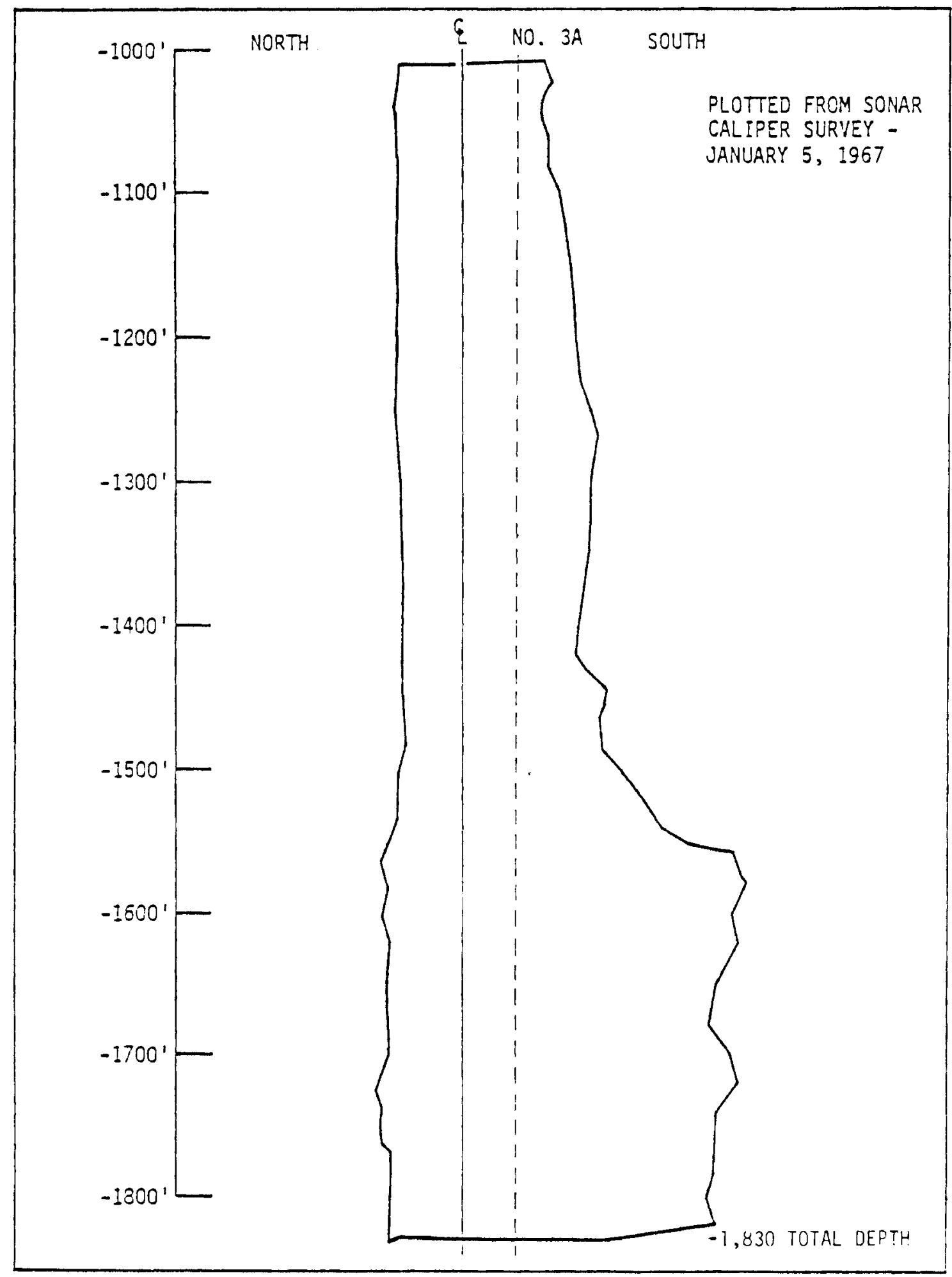

FIGURE 8. Profile - Cavern No. 3 - Bayou Choctaw Dome Source: Fenix and Scisson 1976 


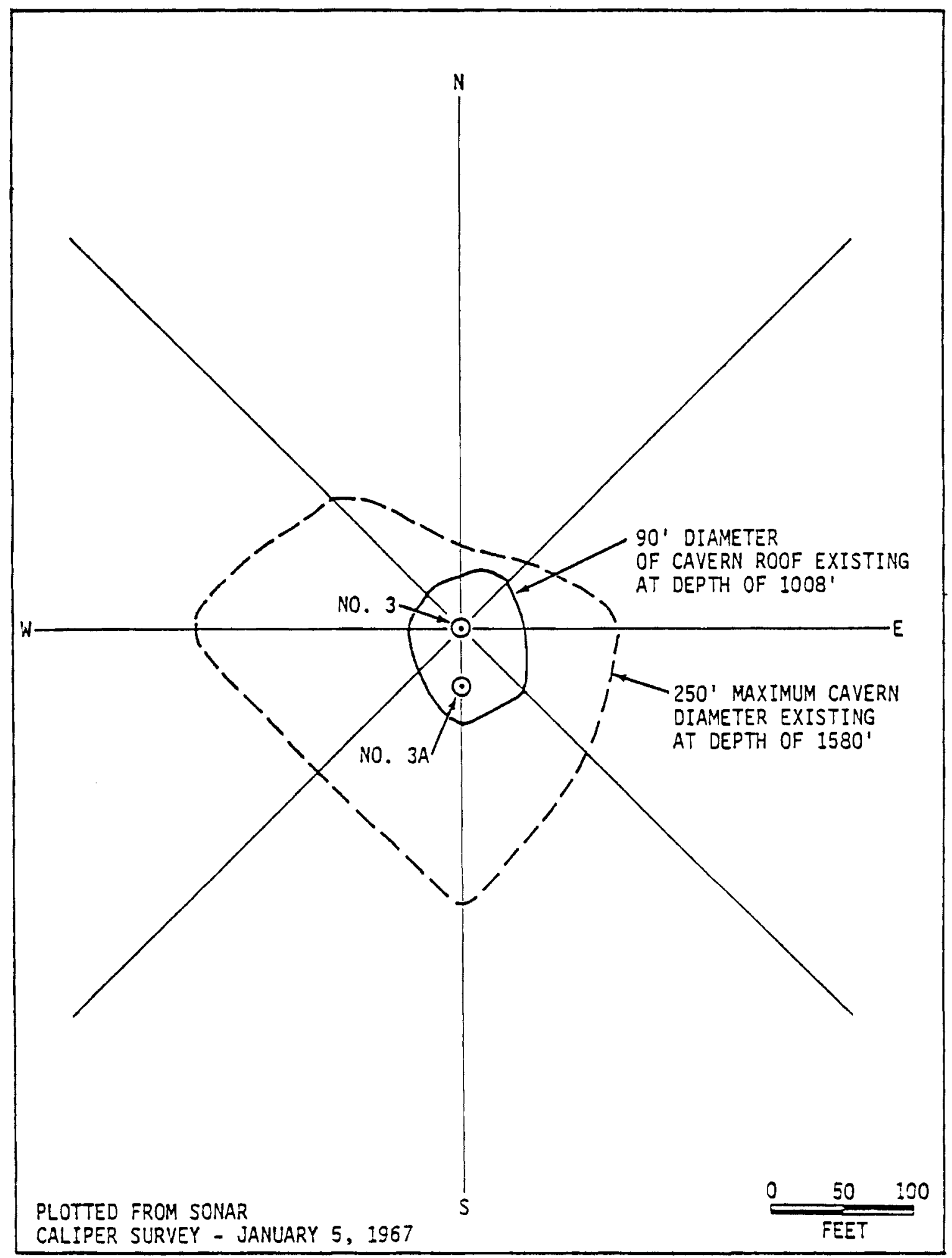

FIGURE 9. Cavern No. 3 - Bayou Choctaw Dome Source: Fenix and Scisson 1976 


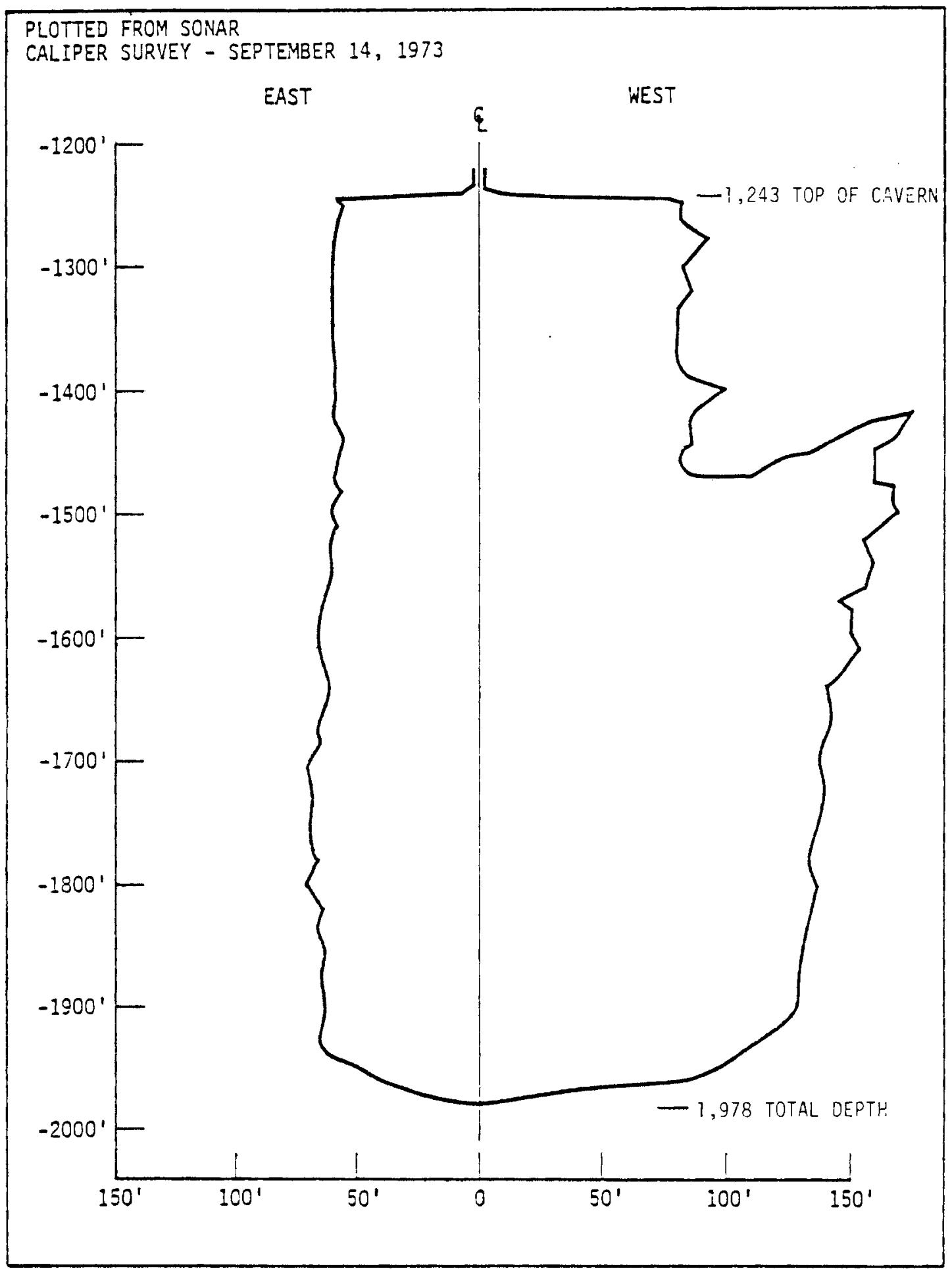

FIGURE 10. Profile - Cavern No. 8A - Bayou Choctaw Dome Fenix and Scisson 1976 


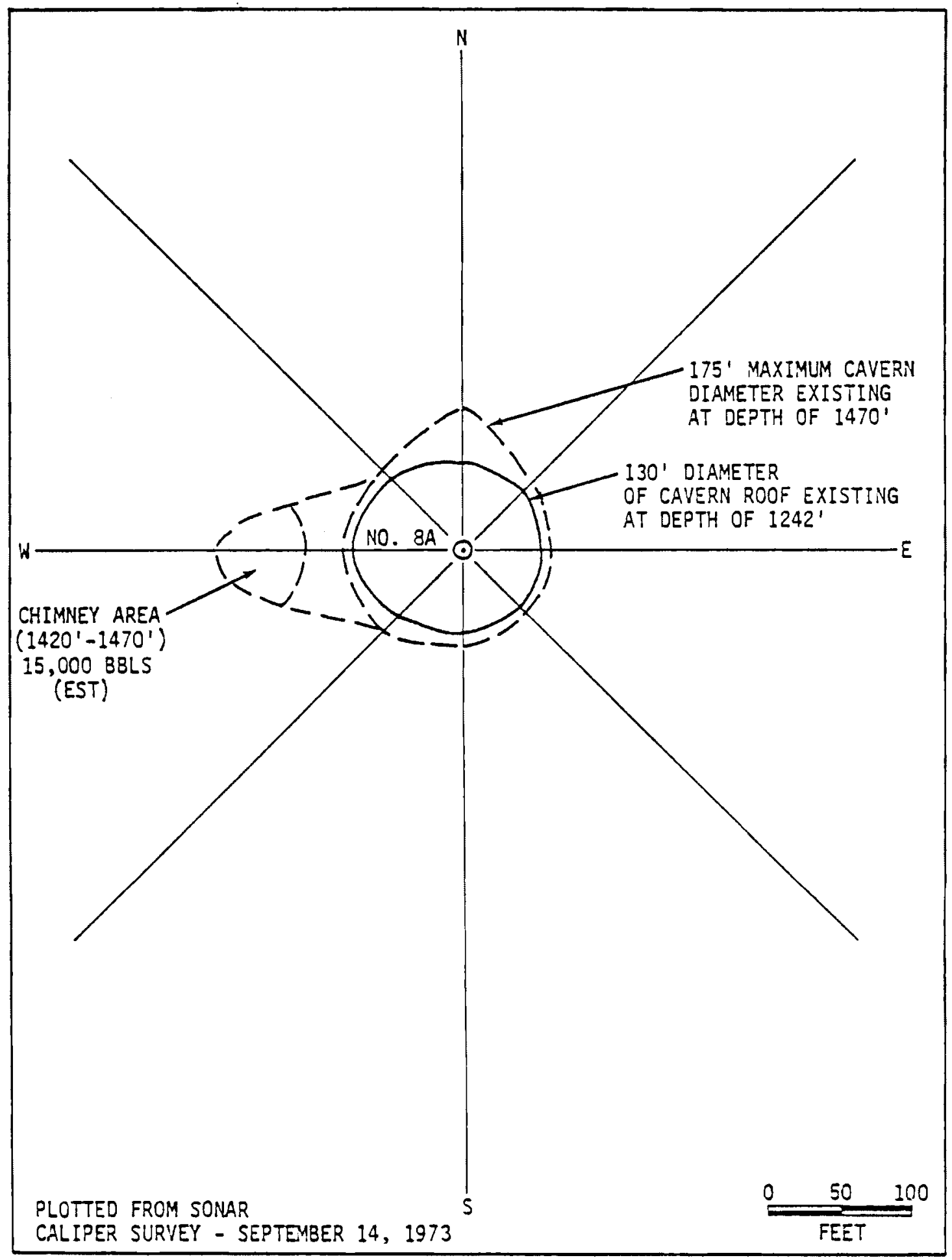

FIGURE 11. Cavern No. 8A - Bayou Choctaw Dome Source: Fenix and Scisson 1976 


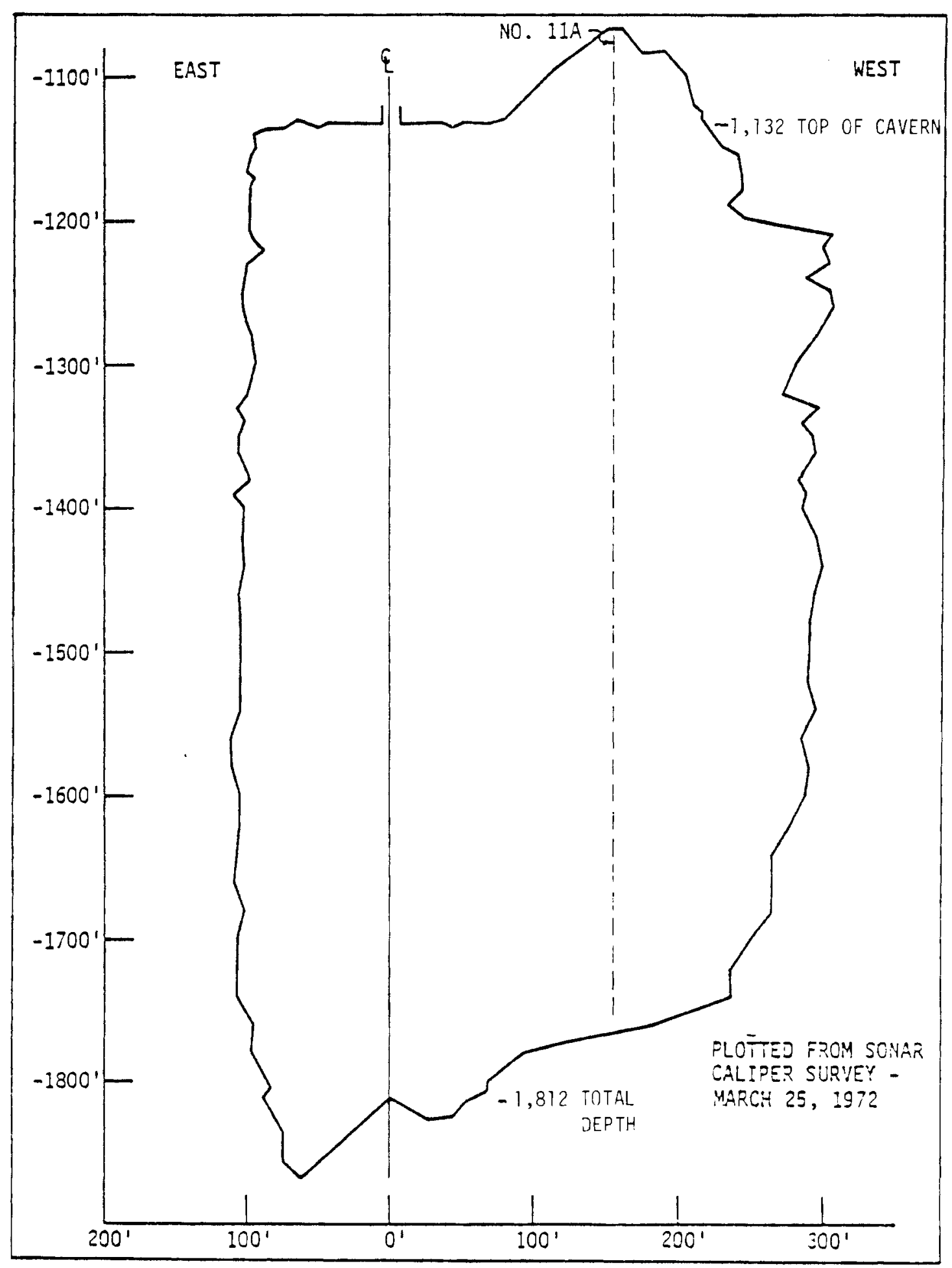

FIGURE 12. Profile - Cavern No. 11 - Bayou Choctaw Dome Source: Fenix and Scisson 1976 


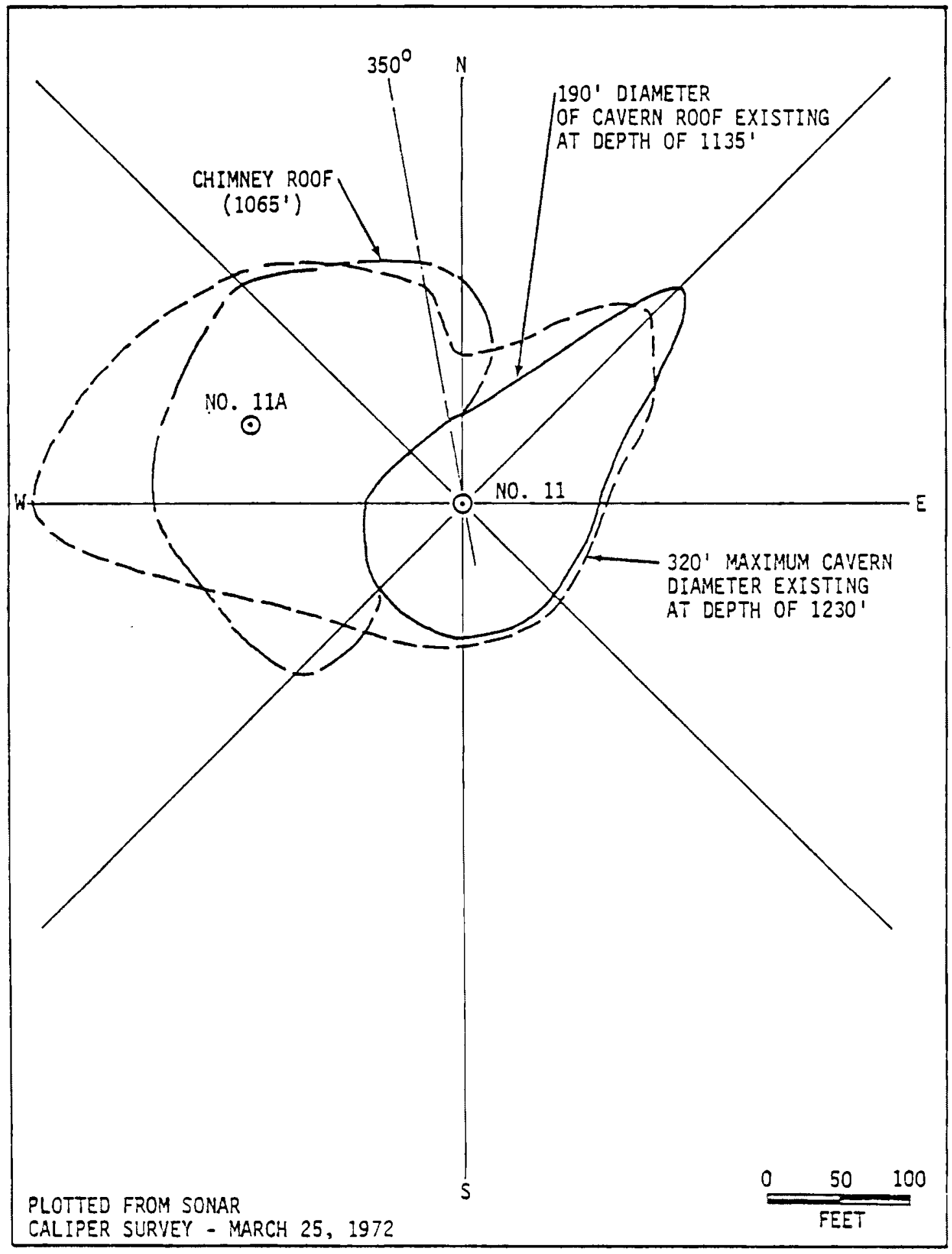

FIGURE 13. Cavern No. 11 - Bayou Choctaw Dome Source: Fenix and Scisson 7976 


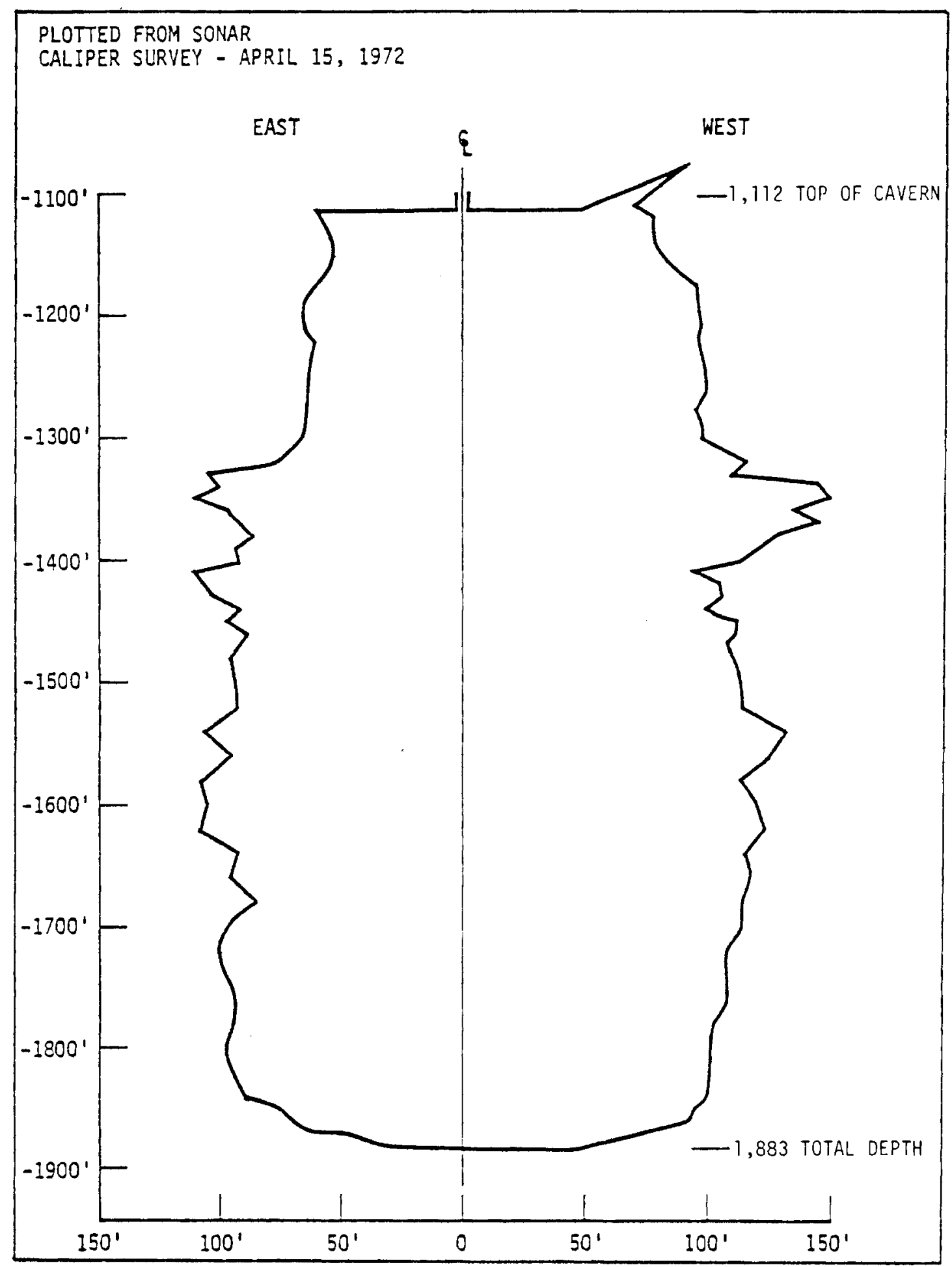

FIGURE 14. Profile - Cavern No. 13 - Bayou Choctaw Dome Source: Fenix and Scisson 1976 


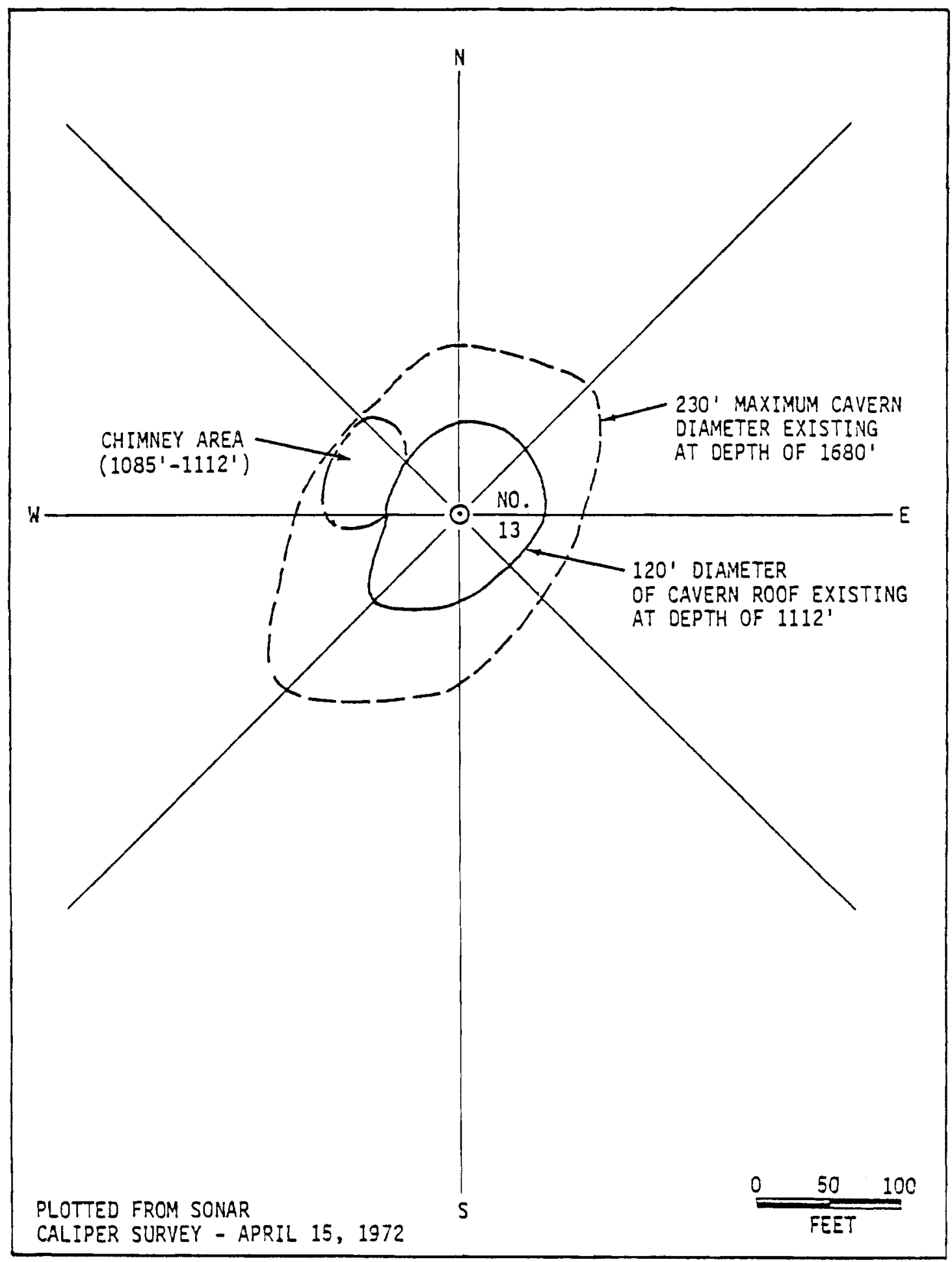

FIGURE 15. Cavern No. 13 - Bayou Choctaw Dome Source: Fenix and Scisson 1976 


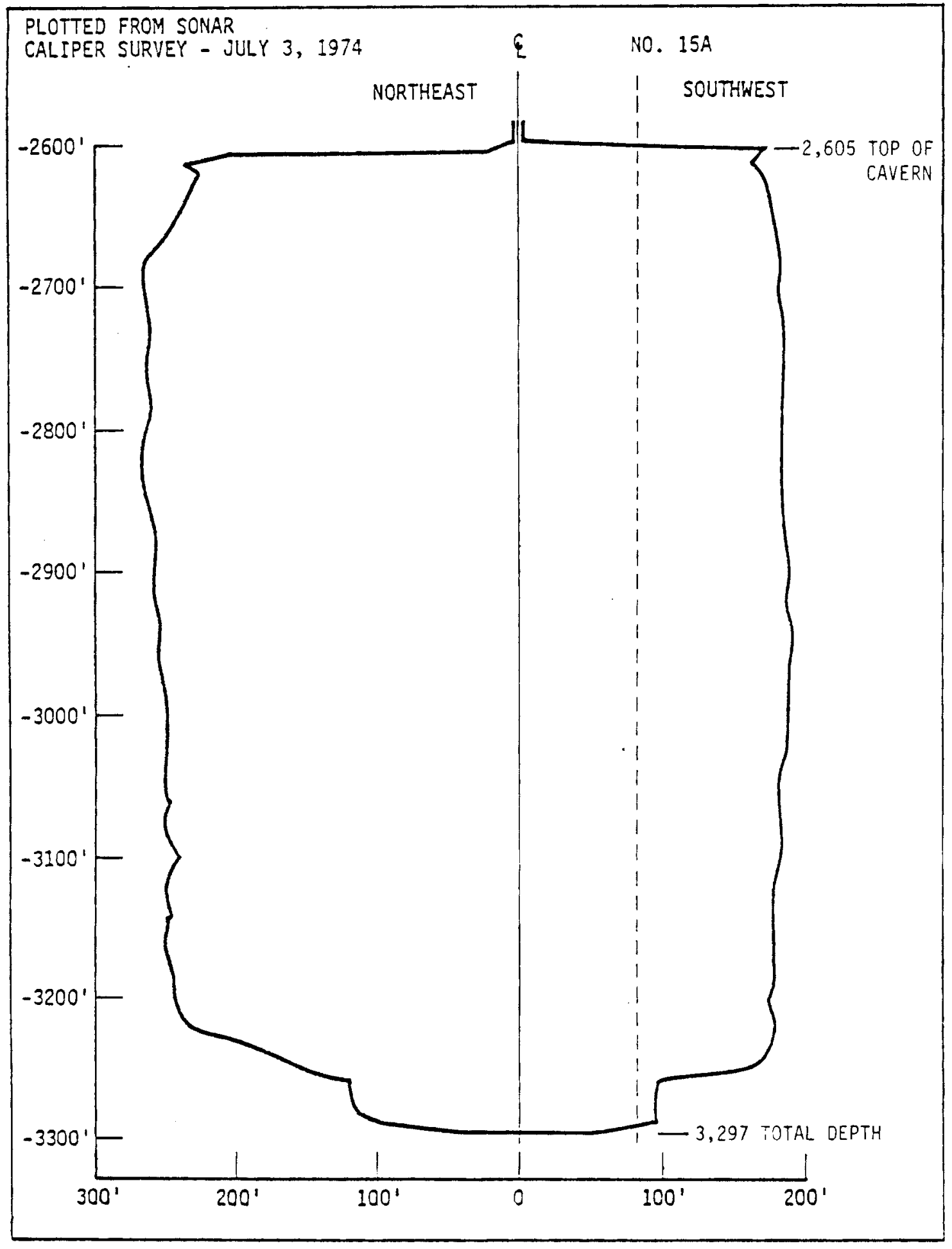

FIGURE 16. Profile - Cavern No. 15 - Bayou Choctaw Dome Source: Fenix and Scisson 1976 


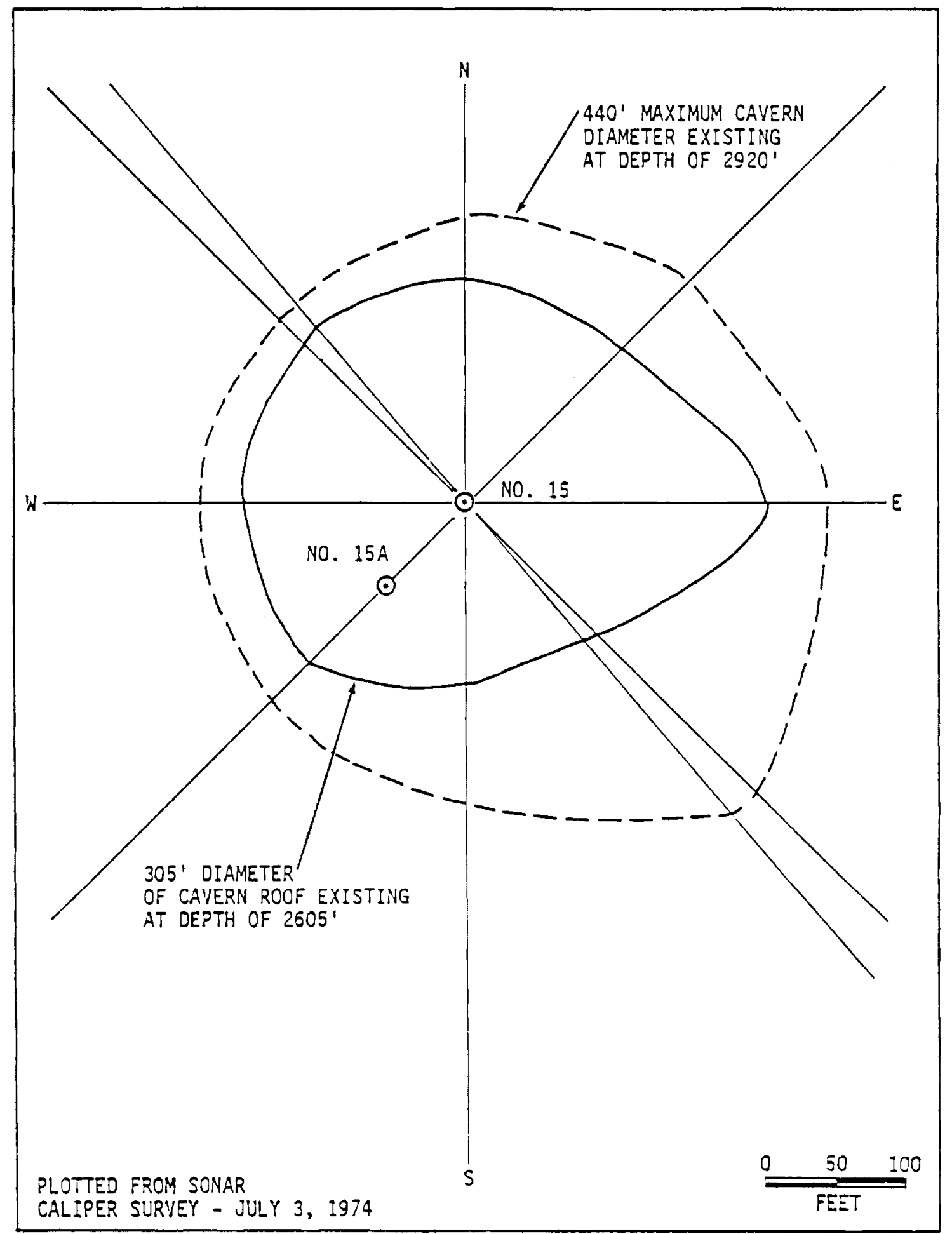

FIGURE 17. Cavern No. 15 - Bayou Choctaw Dome Source: Fenix and Scisson 1976 


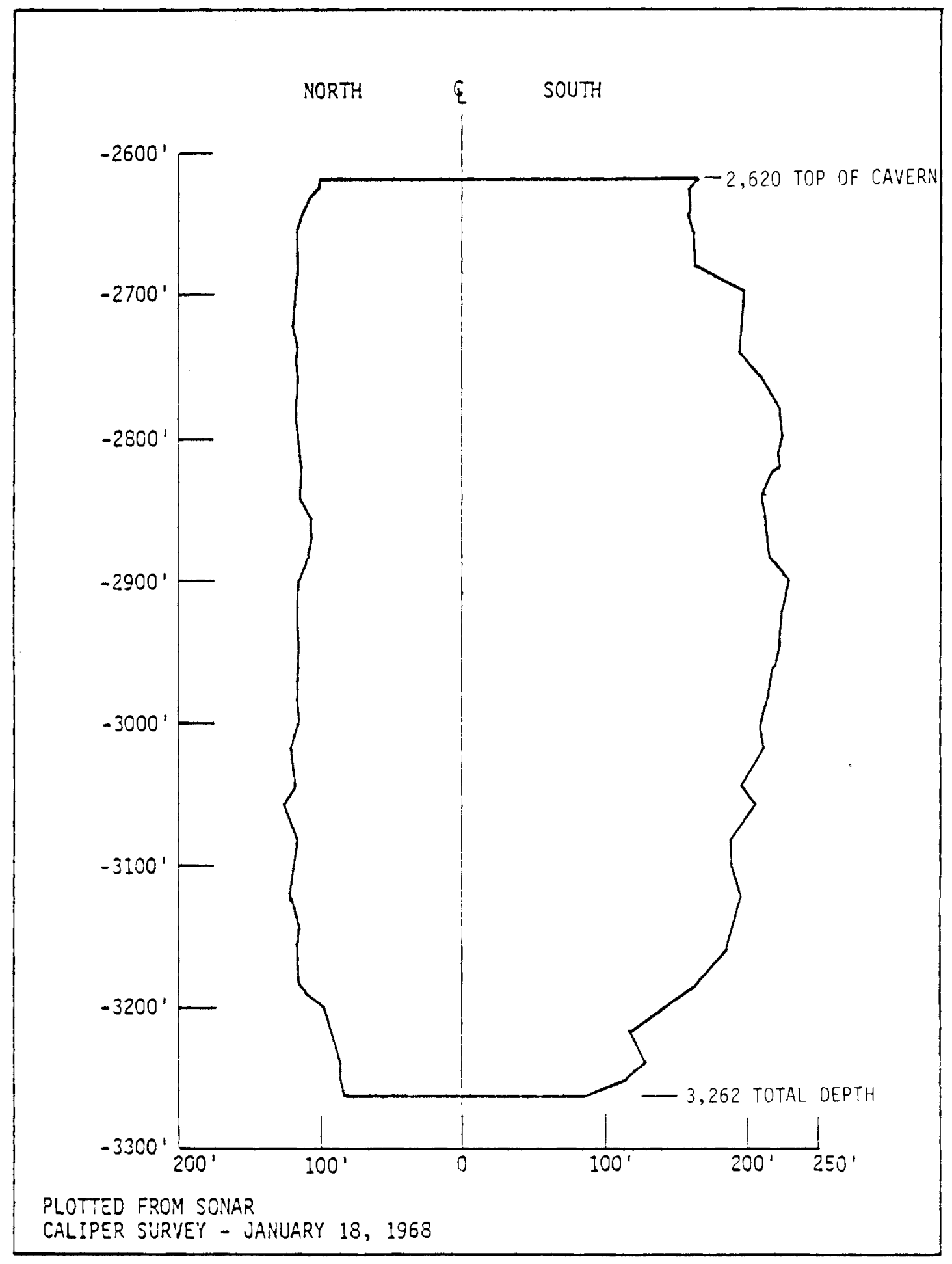

FIGURE 18. Profile - Cavern No. 16 - Bayou Choctaw Dome Source: Fenix and Scisson 1976 


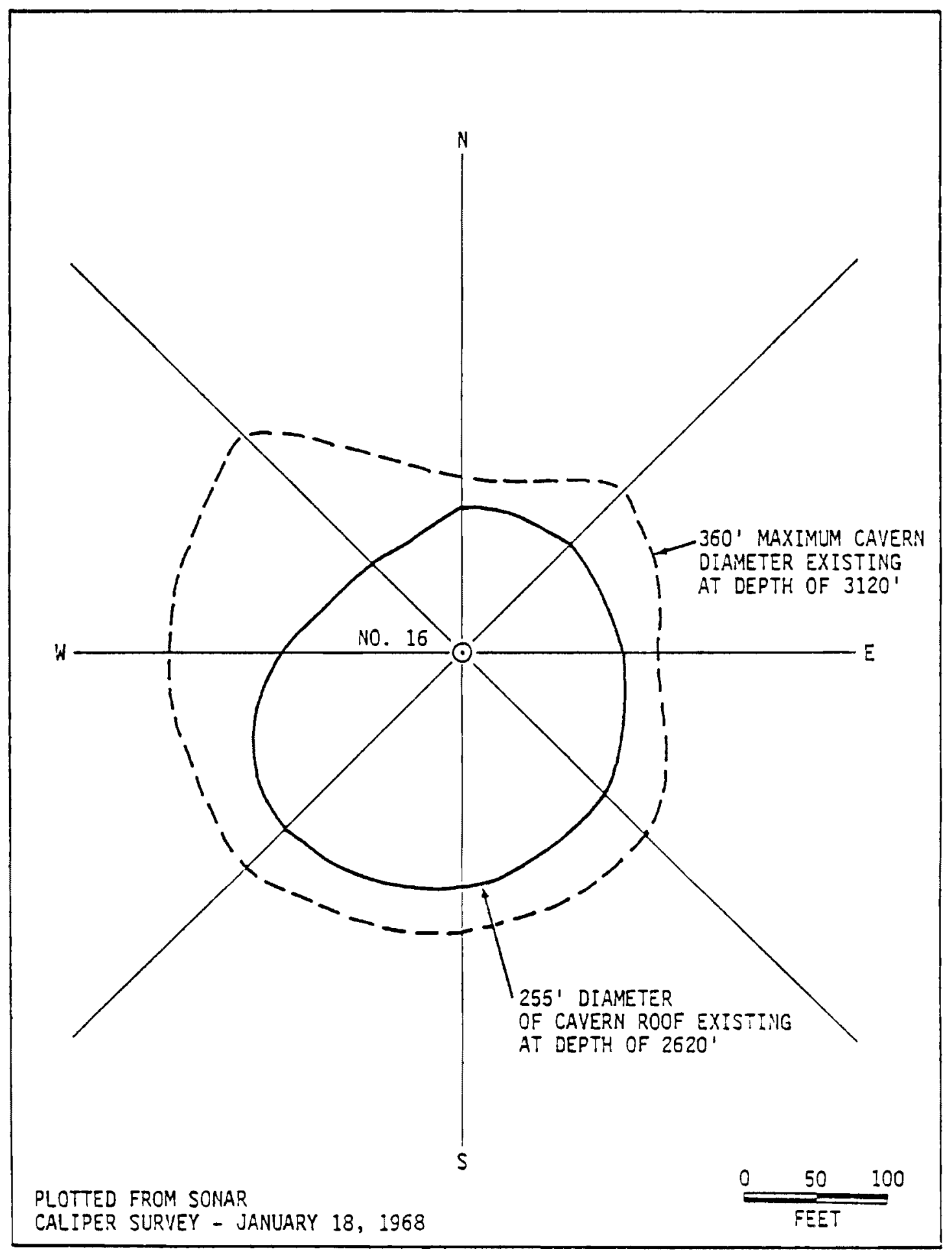

FIGURE 19. Cavern No. 16 - Bayou Choctaw Dome Source: Fenix and Scisson 1976 


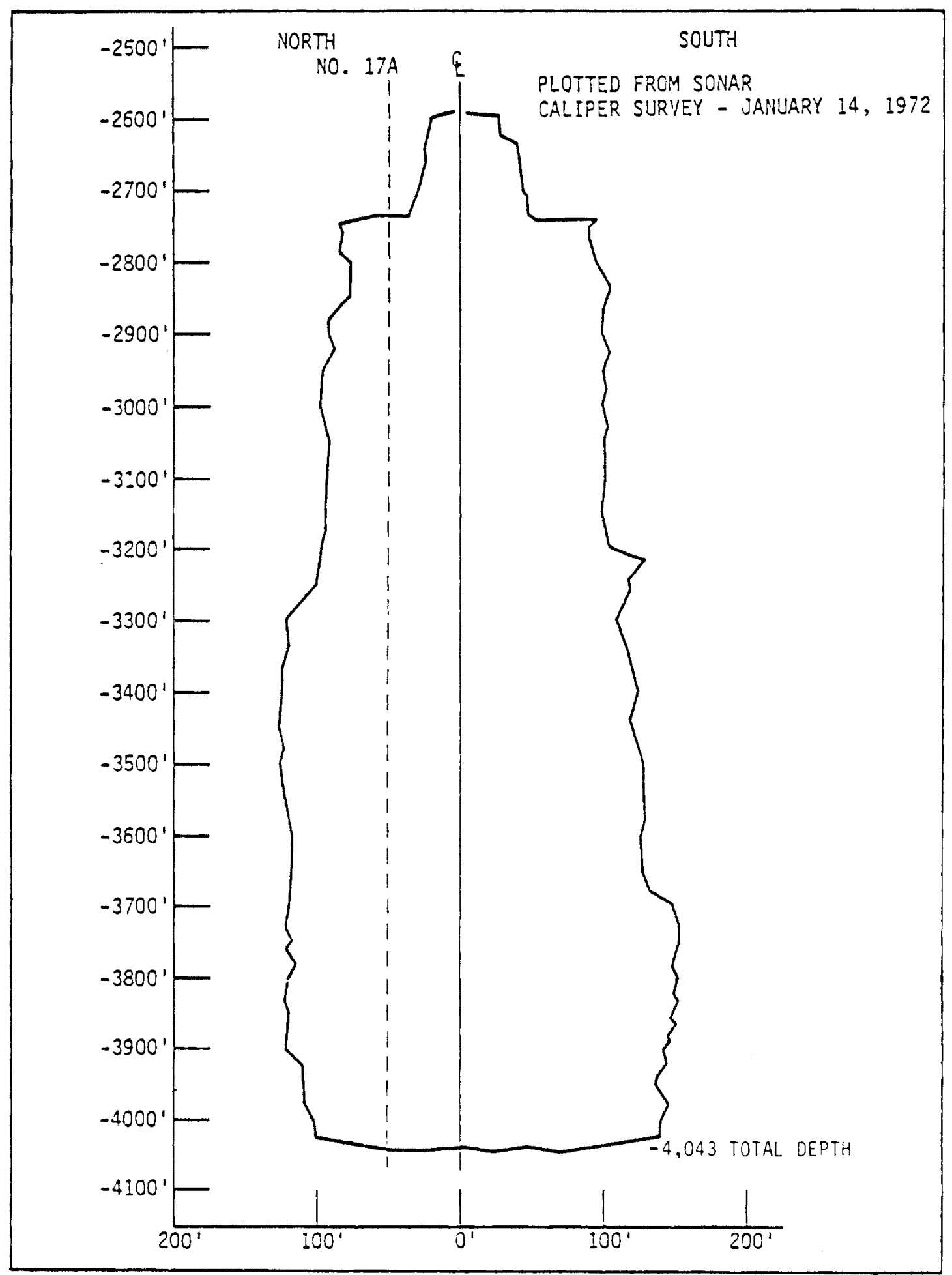

FIGURE 20. Profile - Cavern No. 17 - Bayou Choctaw Dome Source: Fenix and Scisson 1976 


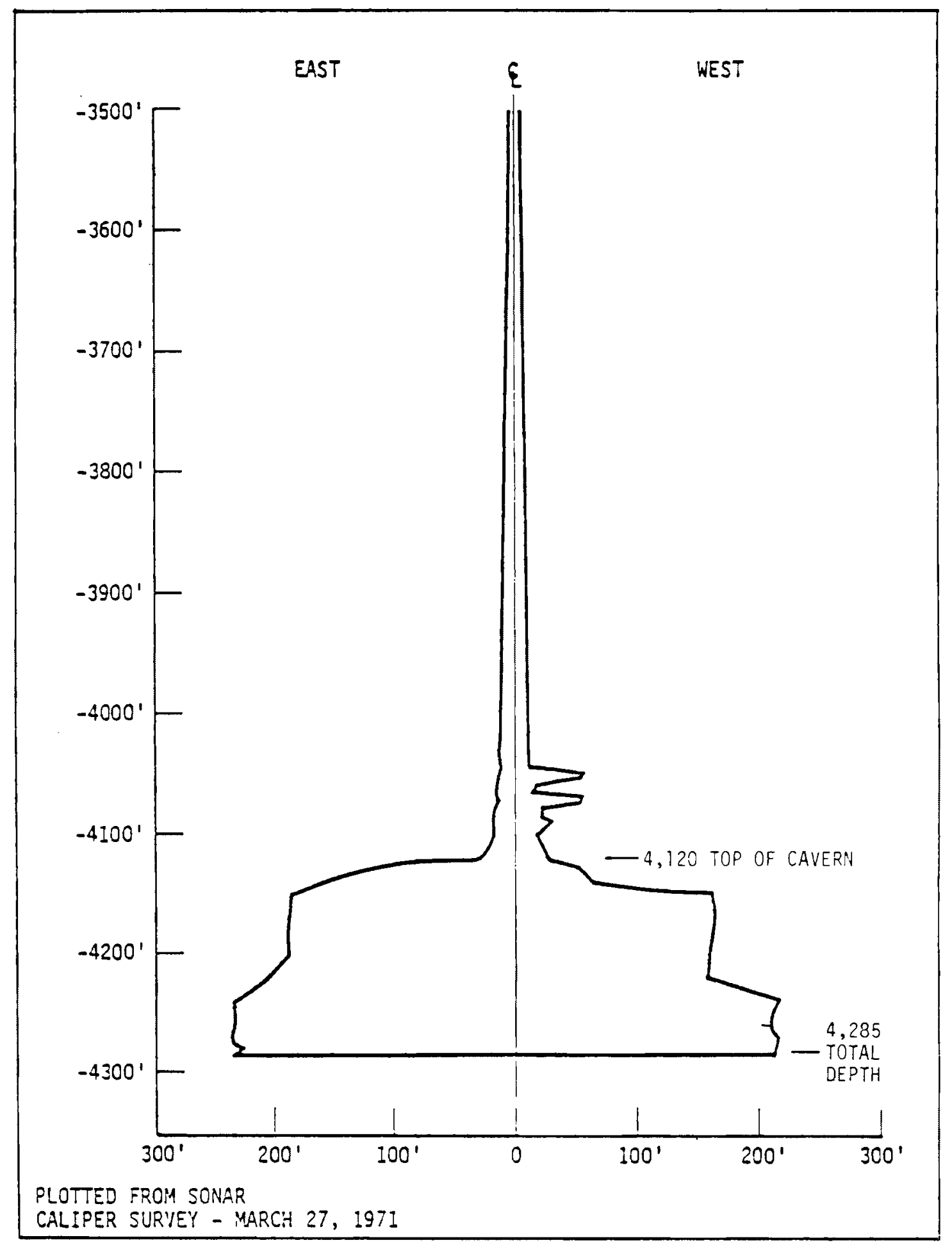

FIGURE 21. Profile - Cavern No. 18 - Bayou Choctaw Dome Source: Fenix and Scisson 1976 


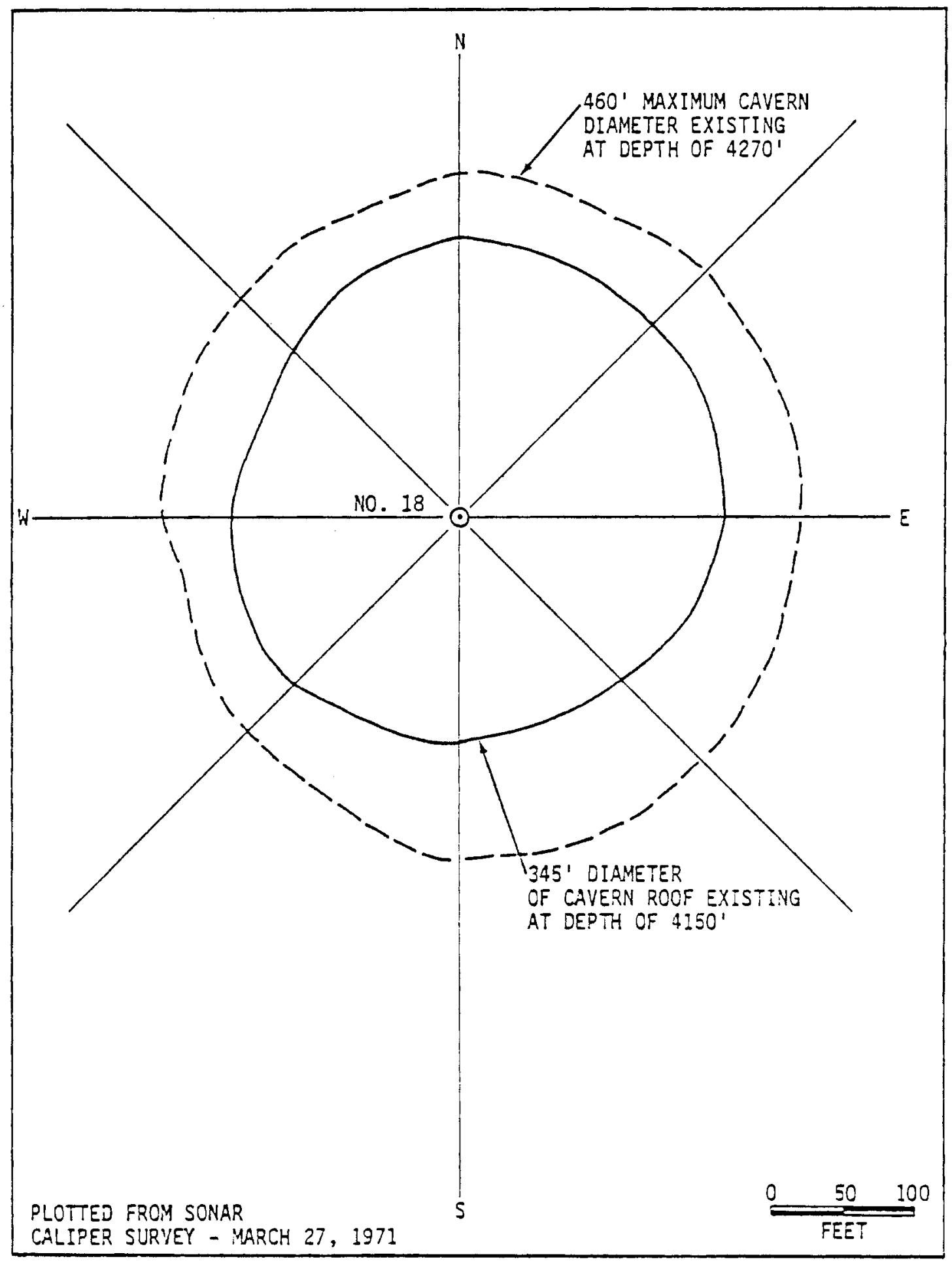

FIGURE 22. Cavern No. 18 - Bayou Choctaw Dome Source: Fenix and Scisson 1976 


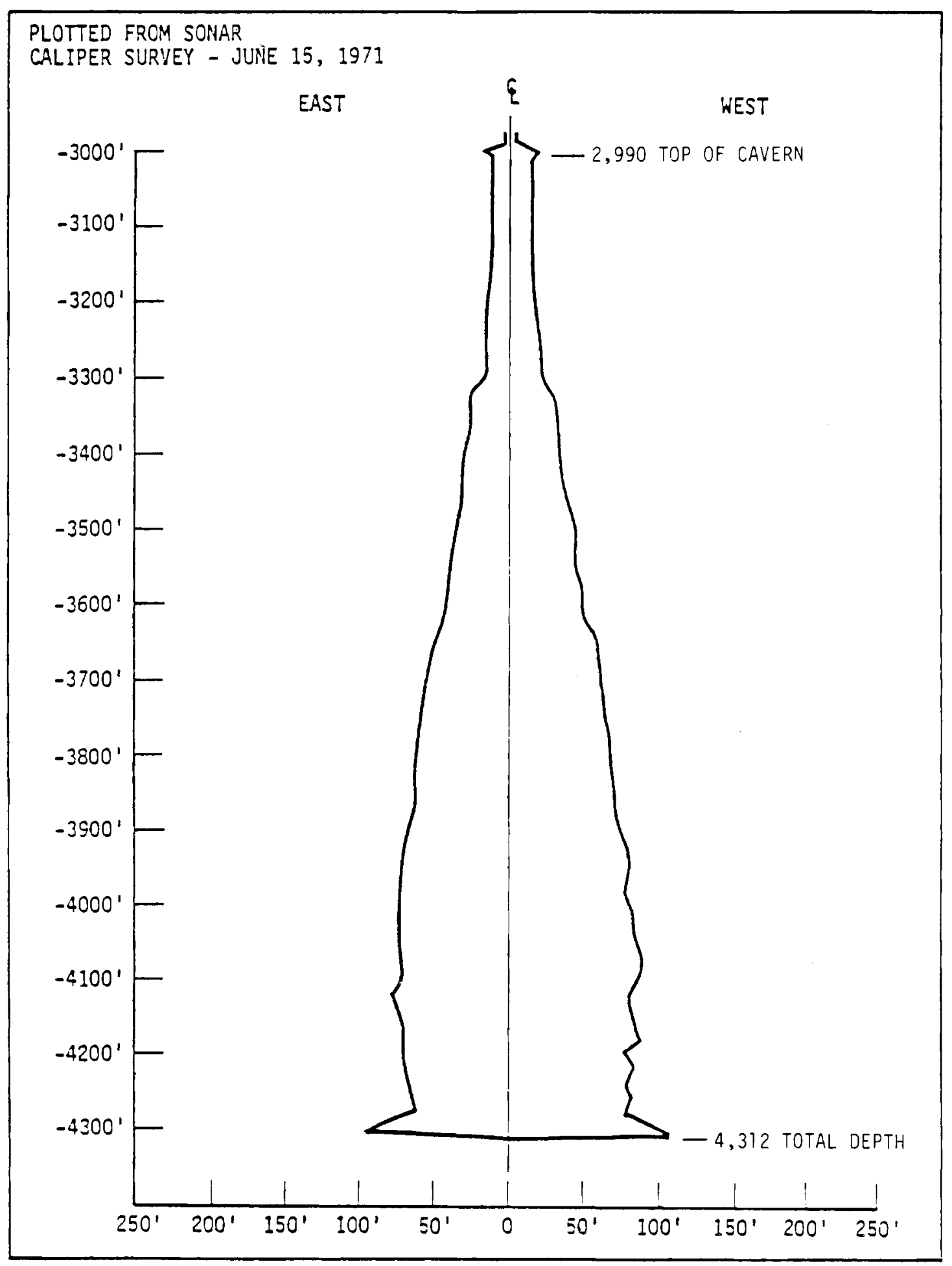

FIGURE 23. Profile - Cavern No. 19 - Bayou Choctaw Dome Source: Fenix and Scisson 1976 


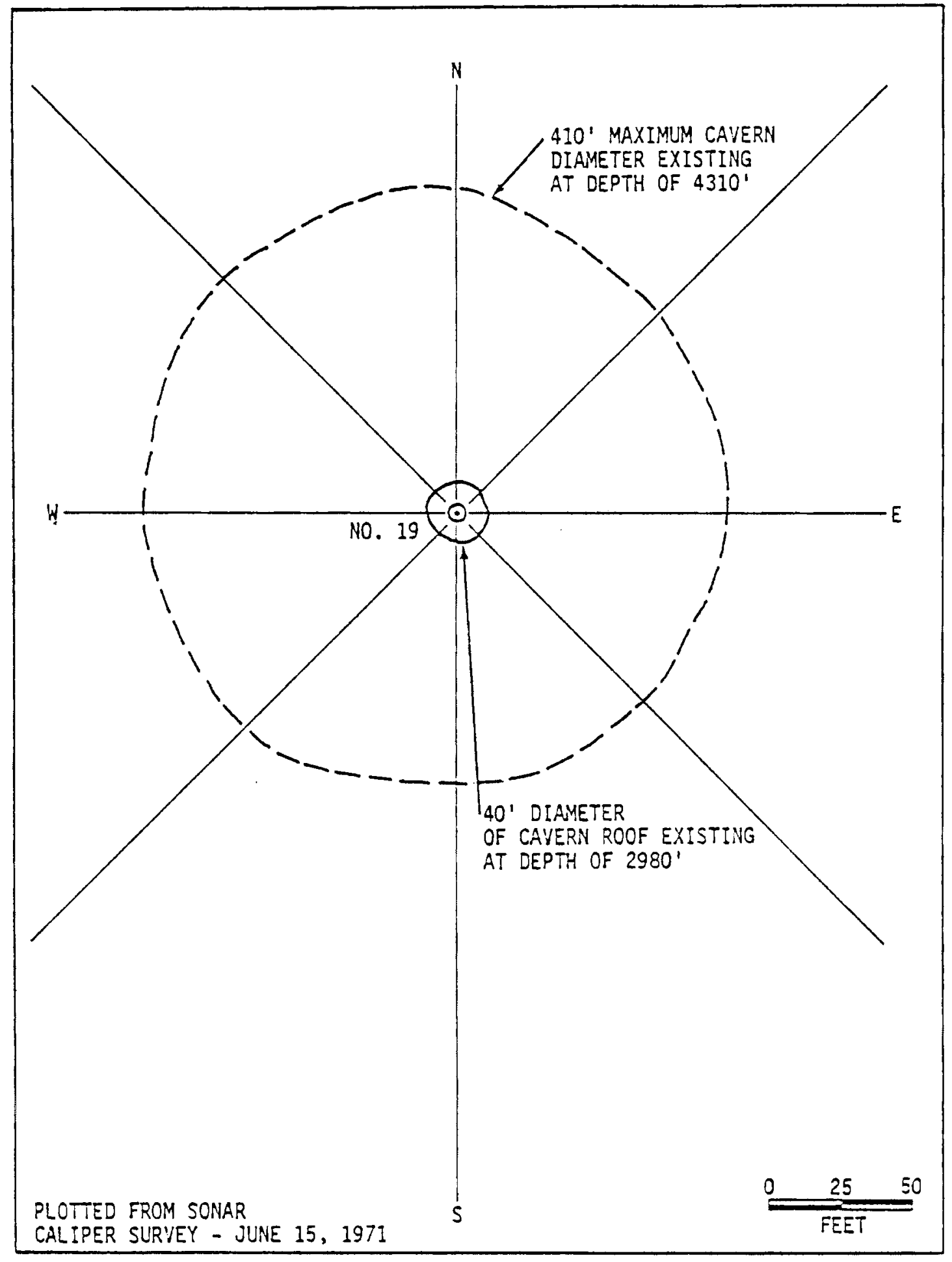

FIGURE 24. Cavern No. 19 - Bayou Choctaw Dome Source: Fenix and Scisson 1976 


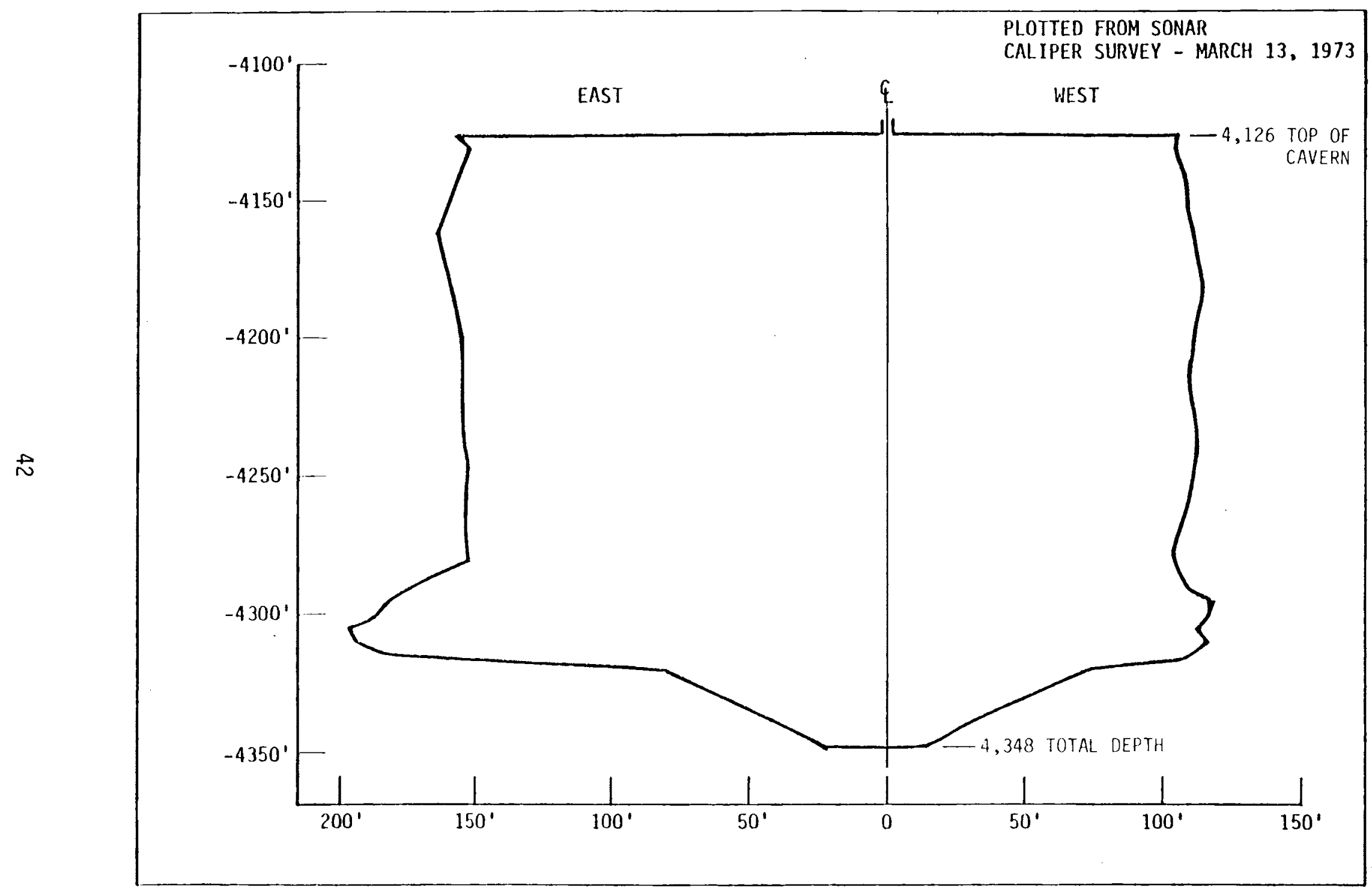

FIGURE 25. Profile - Cavern No. 20 - Bayou Choctaw Dome Source: Fenix and Scisson 1976 


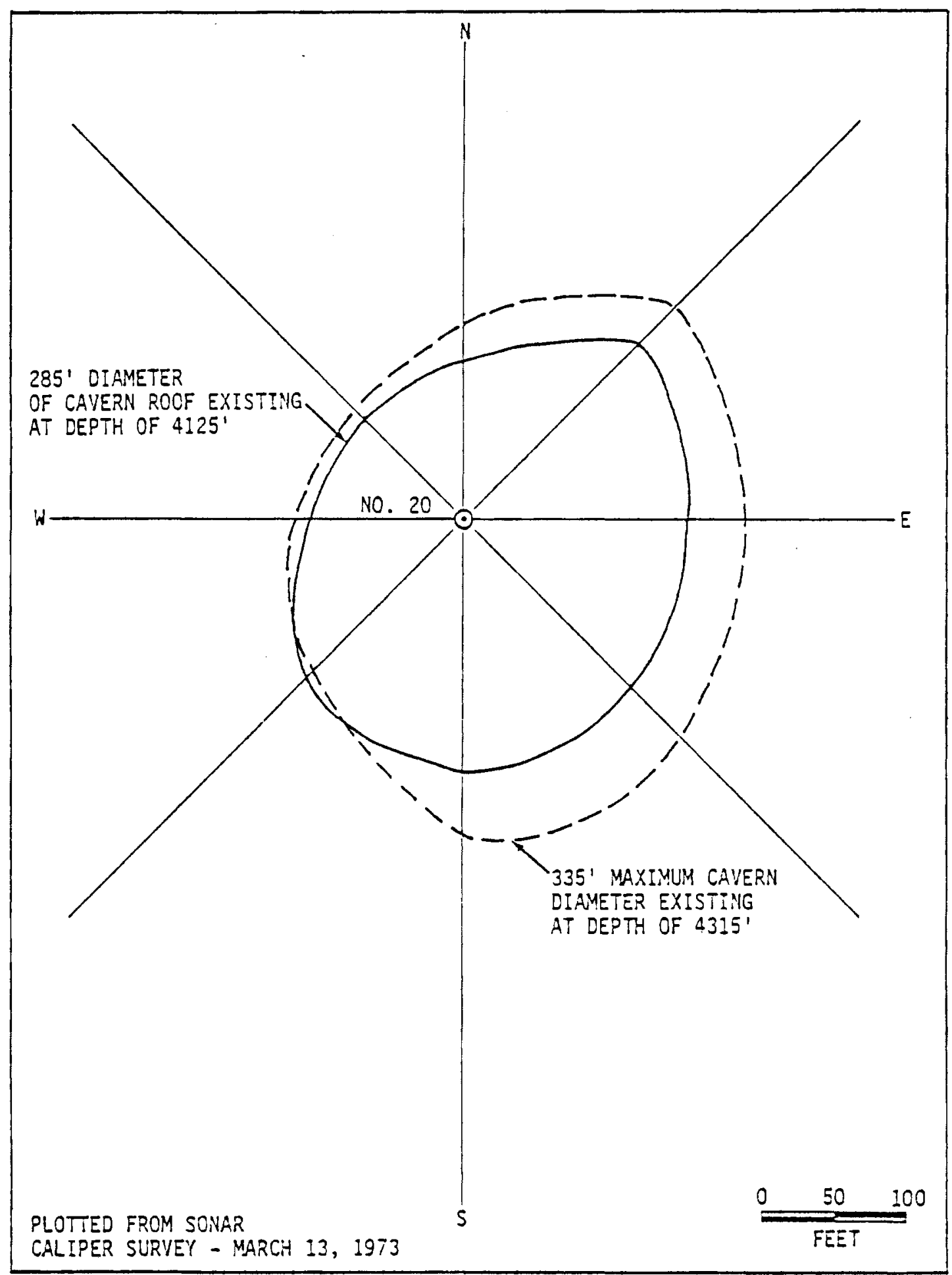

FIGURE 26. Cavern No. 20 - Bayou Choctaw Dome Source: Fenix and Scisson 1976 


\section{SIGNIFICANCE TO WASTE ISOLATION SAFETY ASSESSMENT}

We believe that Bayou Choctaw is a typical dome that has been fully exploited by brining and storage operations. There are some better and some worse from the standpoint of operations and long-term stability. If we assume Bayou Choctaw as a base condition then the conclusions are:

1. The plan area of a depth of 2000 feet of the dome is 1.3 square miles or 36 million square feet. The dome is essentially fully developed. The twenty existing caverns occupy an aggregate plan area of 7 million square feet. Any foreign but unknown body, such as nuclear waste, would have a chance of being breached into with a probability of 7 in 36 . The assumption is that the foreign body lies at the same depth interval as solutioning would take place.

2. One cavern collapse probably can be expected during full exploitation of a salt dome. The assumption assumes that caverns are developed for brine feed to chemical plants. If the caverns are developed as storage caverns the risk of collapse is much lower.

3. Coalescences of caverns can be expected. Of 20 caverns developed at Bayou Choctaw, three are now connected.

4. Caverns occasionally breach into the caprock. At Bayou Choctaw this occurred in 3 of the 20 caverns. At Cavern No. 7 this caused total collapse and mixing of salt brine into surface waters. No collapse has occurred at Caverns No. 4 or 10; however, communication of the cavern brine and the caprock aquifer has occurred. 
BREACH SCENARIO WHICH COULD LEAD TO RELEASE OF RADIO-

ACTIVE WASTE VIA INADVERTENT SOLUTION MINING

If administrative control is maintained over a radioactive waste repository located in a salt dome, then solution mining will be prevented. If the waste is known to be present, but solution mining is permitted then we assume that some emergency condition exists that overrides the requirement to maintain isolation. Hence, the "worst case" scenario must be a situation where:

(1) administrative control has been lost, (2) no record remains to warn of the presence of the waste, (3) man has either maintained or redeveloped his technology of solution mining, and (4) he has the need for either brine or the desire to create underground storage.

Given these assumptions, then the following is a logical scenario.

\section{SITE SELECTION}

The Gulf Coast Embayment domes are well defined and it is doubted that many more remain to be discovered. Credit for discovery of domes goes to petroleum and sulfur explorers who in turn were driven by the high success ratio of discovery over and on the flanks of salt domes. Both of these resources are being rapidly depleted, and little incentive is expected to exist for such exploration beyond the next 100 years. However, should radioactive waste be placed in a virgin dome that does have hydrocarbon or sulfur associated with $i$ ts boundaries then future explorers would no doubt be tempted to test the structure once adminstrative control over the site was lost. It is reasonable to assume that any dome selected as a waste repository would be one barren of resources. Therefore, we conclude that man is more apt to select a salt dome for mining, brining or storage use in the time after 100 years than for hydrocarbons or sulfur.

Future generations will select a salt dome using criteria much similar to what are being considered for waste disposal sites. Identical factors would be: (1) absence of natural or induced dissolution of salt, (2) reasonable depth to salt, (3) simple geometric shape, (4) good access and availability 
of power, and (5) proximity to population centers. Therefore, future generations are apt to deliberately select a dome for development that was chosen as a waste disposal site. The odds are further increased because the number of virgin domes available is being rapidly depleted.

Our conclusion is that a conflict between a repository and eventual mining or solutioning in that dome is inevitable unless administrative control over the repository is maintained. The conflict can be expected to occur soon after decontrol. To conclude otherwise must assume that an industrialized society such as we know it does not exist in the Gulf Coast Embayment. We have estimated that most of the existing dome sites suitable for storage or salt resources will be exhausted in the next 385 years.

\section{EARLY DETECTION OF THE PRESENCE OF RADIOACTIVE WASTE}

Let us assume that man in some future generation has selected a dome containing radioactive waste of which he is not aware. What are the chances that he will detect it early? If his technology is similar to ours we believe he would get early warning if he actually penetrates the waste. Our reasoning is that he would be collecting and testing drill cuttings and running wireline geophysical sensors, including gamma ray. Therefore, early warning will occur if he penetrates the waste. His ability to cope with the release will depend on how quickly he will respond to the unusual find. The probability that his drill bit will pass directiy through waste or radioactively damaged waste depends on the distribution of such waste. Exact numbers are not available as to the probability of drilling directly into a waste canister, but Sandia Laboratories gave a probability of 0.01 for this eventuality at the Waste Isolation Pilot Plant (WIPP) site near Carlsbad, New Mexico. A typical dome would have in the order of 20 bore holes, but they would be drilled sequentially as the need for new caverns arose. Therefore, we conclude that the probability for early detection lies somewhere between 0.01 and $20 \times 0.01$ with a skew towards the lower number.

\section{SOLUTIONING BEGINS. WHEN WILL THE CONTAMINATION BE DETECTED?}

Although there is a high probability that the presence of waste would be immediately detected in the case of drilling directly into a canister, we do 
not feel that the presence of radioactivity would be detected from the brine effluent once solutioning operations were underway. We simply cite that radiation detectors are not being used to monitor brine production today. It is not logical to assume that future generations will either. Detection would result from nearby environmental monitors or actual health effects on man, plants or animals. Hence, contaminated brine could be produced for months or years before discovery.

\section{AT WHAT RATE WILL CONTAMINATED BRINE BE PRODUCED?}

The rule of thumb used in the industry is six volumes of water for one volume of salt. If a facility is producing the equivalent of 1 million tons per year of solid salt, then it will need to produce 110 million gallons of brine per year. This is a little more than 2000 gallons per minute. The degree of contamination of the brine depends on dilution and solubility of the waste. Waste canisters can be expected to tumble towards the tubing string at the bottom of the cavern. Thus it can be expected to be in the direct flow path regardless of whether direct or indirect circulation is used.

\section{WHAT WILL HAPPEN TO THE BRINE PRODUCED?}

If solutioning is taking place for brine production it will be fed to a chlorine plant to produce hydrochloric acid and, in some instances, caustic soda. These are basic chemicals that have wide industrial use. Much of the chlorine goes to eventual use in the plastics industry. If the solutioning is done to provide storage space, then the brine ends up in one of five places: (1) in chlorine or caustic soda plants, (2) reinjected into permeable sands near the dome, (3) in solar evaporation ponds (the salt probably to be sold for road de-icing), (4) disposed of in nearby rivers, or (5) sent by pipeline to the Gulf. Option No. 1 is the most favored from the standpoint of economics. Option No. 5 is not likely for the inland domes of Louisiana or Texas from an operational sandpoint. Option No. 2 is probably the hoped-for method from the standpoint of consequences of radioactive release. We conclude that each of the five disposal methods have equal probability of being selected. 


\section{WHAT WOULD OCCUR IF A CAVERN INADVERTENTLY BREACHES TO THE SURFACE?}

Brining operations obviously would stop. However, convection and diffusion would continue to cause some release of radioactive material. Experience has indicated that breached caverns or ones that come into contact with the caprock become "self leaching", i.e. continue to enlarge. Experience at Bayou Choctaw indicates that one collapsed cavern and two additional breaches into caprock can be expected on a single dome. If the use is solely for storage then more care can be expected to be used in cavern development. However, we feel only justified in reducing the probability of collapse to less than 1 in 20 domes (equivalent to 1 in 400 caverns) or breaching into the caprock less than 1 in 10 domes (equivalent to 1 in 200 caverns).

The mechanics of flow in collapsed caverns or caprock breaches is not known. The Texas Bureau of Economic Geology and the Kansas Department of Health and Environment are conducting basic studies of collapsed structures. Specific data will be available only after these studies are complete. 
The essential conclusion is that there is a high probability that solution mining will be conducted in a dome used for radioactive waste storage unless administrative control is maintained over the site, or there is some means of forewarning against such activities. By high probability we mean almost a certainty.

\section{Specific Probabilities for Individual Events Are}

Time when solution mining starts

Probability of dome being selected

Probability of early detection of

nuclear wastes (pre-solutioning)

Time before detection during solutioning

Probability waste will not be contacted contacted during solutioning

Probability that brine will go to:

Chemical plant

Reinjection underground

De-icing

Surface waters

Gu if Coast

Probability that a cavern will collapse resulting in a permanent breach

Brine Caverns

Storage Caverns

Probability that caverns have hydraulic communication with caprock

Brine Caverns

Storage Caverns

Production Rate of Brine Until Detected
0 to 385 years

High, nearly 1

0.01 to 0.2

1 month - 1 year

0.10 to $\mathrm{nil}$

0.2

0.2

0.2

0.2

0.2

1.0/dome

$0.05 /$ dome

$1.0 /$ dome

$0.1 /$ dome

$2000 \mathrm{gal} / \mathrm{min}$ 


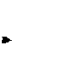


APPENDIX A

ANNOTATED BIBLIOGRAPHY OF GEOLOGICAL DOCUMENTS RELATED TO THE STRATEGIC PETROLEUM RESERVE PROGRAM 
Acres American, Inc., November, 1976, "Strategic Petroleum Reserve, Underground Mined Storage, Ironton Mine Geotechnical Study," 32 p.

The object of the study was to "confirm that "Ironton limestone mine at Ironton, Ohio is geotechnically suitable for the long-term storage of crude oil. To assess cavern stability and oil containment, the following tasks were performed: an in-mine survey, diamond core drilling from the surface, water pressure testing in the lower sections of boreholes, laboratory testing and data analysis. It was concluded that from a technical standpoint the Ironton mine would be suitable for crude oil storage. The geology sections are basically derived from the in-mine survey and are site specific to the mine. The geological discussion is limited to the formation which contains the mine (Maxville formation), fractures and joints in the mine, and mine hydrogeology.

Acres American, Inc. in association with RE/SPEC Inc., November, 1977, "U.S. Federal Energy Administration National Strategic 0il Storage Program: Weeks Island Mine Geotechnical Study," Volume 1. Undertaken for Gulf Interstate Engineering Co. under contract FEA-1251-75, 61 p. plus figures and tables.

Volume 1 of the geotechnical report on Weeks Island Mine includes a history and geology of the Weeks Island dome, the field and laboratory investigation program, mine stability and containment, mine conversion, evaluation of safe web thickness, and monitoring and inspection sections. Although I have not seen the appendices (Volume 2), there is a report included on the geology by Dr. D. H. Kupfer, as well as data supplied by Morton Salt Company, and the results of laboratory tests. From looking at Volume 1 alone, this report does not appear to be as thorough geologically as the Golder Assoc. report on Cote Blanche and concentrates more on the engineering aspects of the problem.

Testimony of Michael F. Carosella (DOE), Neal Van Fossan and Peter Kelsall (Gulf Interstate Engineering Company), and Ron Kear (Dames \& Moore) before the State of Louisiana, Office of Conservation, August 16, 1978, Docket Number 505-78-4.

Carosella is Acting Director of the program planning division of the SPR program and came to provide technical information on the Weeks Island site. He made no comments on geology. 
Van Fossan is vice president of Gulf Interstate. His testimony includes geologic evidence on Weeks Island dome, a cross-section and structure contour map. He seems to have very specific geologic information but it is not presented with this report. At Weeks Island dome hydrocarbon prospecting began in 1905 with 282 wells drilled prior to 1978. The location of $0 i 1$ and gas wells are plotted on the structure contour map.

Kelsall is Supervising Engineer for Gulf Interstate and describes the mine history, conversion for storage and operating method for SPR. He describes the geotechnical investigation to confirm the suitability of the mine for storage, i.e. over a 40-50 year operating period the mine would remain stable and would retain crude oil. He refers to the Acres American, Inc. study and report by Dr. Donal Kupfer of LSU. Kelsall refers to "blowouts" in salt, shear zones in lower levels of the mine, slabbing or exfoliation of pillars, and salt creep. He states the latter two are not zones of structural weakness which will be detrimental to the stability of the cavern; and the former two will not occur at a significant rate.

Kear is an associate of Dames \& Moore. His testimony had no comments on geology.

Dames \& Moore, October 10, 1978, "Preliminary Draft, Napoleonville Dome Brine Injection Feasibility and Environmental Assessment Report."

The alternative methods of disposing of 1.9 billion barrels of brine from leaching that are considered are disposal in the Gulf of Mexico or at several candidate well fields around Napoleonville dome. Seismic data has been ordered to determine the existence of possible faults and no-flow boundaries in the aquifers. The drilling of a brine disposal test well is suggested to measure well and aquifer performance.

Ecology and Environment, Inc., July 19, 1978, "Feasibility and Terrestrial Environmental Assessment of Brine Disposal Via Subsurface Injection at the Bryan Mound SPR Site."

This report was the result of an EPA request for further information on deep well brine disposal at Bryan Mound before taking action on a permit 
application to discharge the brine into the Gulf of Mexico. The discussion includes the geologic environment of the upper and lower disposal reservoirs, the groundwater resources, seismic and fracture risks, influence on adjacent $0 i 1$ and gas production, adjacent exploratory holes, well arrangement and vertical separation, injection pressure, potential constraints and limitations, hydraulic conclusions, a reservoir analysis, ISF/sonic logs of the pertinent disposal zones and core logs.

Fenix \& Scisson, Inc., May 1976, "Final Report, Project I, Investigation of New Leached Caverns in Salt Domes," Volumes I and II.

Project I is a prototype study of five primary sites and eight alternate sites for the storage of crude oil as part of the Strategic Petroleum Reserve program. For each of the 13 domes (Chacahoula dome, Allen dome, Black Bayou dome, Napoleonville dome, Eugene Island dome, White Castle dome, Iberia dome, Vinton dome, Nash dome, West Columbia dome, Damon Mound dome, Big Hill dome, San Luis Pass dome), facility identification, design, and cost studies were conducted. For each dome a 20- to 30-page geology section is presented which details physiography, regional geology, local geology, salt dome configuration, gas and oil production, leaching water supply, brine disposal, floods, wind, seismic risk, mineral ownership, and exploration required. Geologic cross-sections, structure contour maps (1000-ft contour interval) and seismic risk maps are provided.

Fenix \& Scisson, May 1976, "Final Report, Project II, Engineering Feasibility Study of Underground Storage in Existing Leached Caverns in Salt Formations."

In this study, data on the feasibility of storing crude oil in salt domes was collected and analyzed for the Early Storage Program, and three primary sites were selected (West Hackberry, Bayou Choctaw and Bryan Mound). The present report is a detailed technical, environmental, and cost analysis for West Hackberry, Bayou Choctaw, and Sulphur Mines (an optional site) salt domes. The study of the Bryan Mound site was assigned to the Dallas office of the FEA. For each of the three sites, the geologic considerations (regional, local, caprock, salt, oil and gas production, 
present storage, flood, wind and seismic risk, exploration required) are discussed. Geologic cross-sections, structure contour maps and seismic risk maps are included.

Golder Associates, October 1977, "Report to Gulf Interstate Engineering Co. on Geotechnical study of Cote Blanche Island Salt Mine, New Iberia, Louisiana," Volume I, Text and figures, $161 \mathrm{p}$.

The study of Cote Blanche Island salt mine was made to determine the suitability of the existing mine to store crude oil as part of the SPR program and to assess geotechnical problems which might arise in relocating the existing mine above the oil storage cavern. Descriptions of the regional and site geology, the features mapped during the field investigation program, an assessment of the stability of the mine and the containment properties of the salt are included. Much of the geology is based on a report prepared by Dr. D. H. Kupfer which appears in the Appendix (Volume II). In Volume I, a compilation of existing data as well as new data gathered for this study is presented and appears thorough. The data is well documented and many references are pertinent to SPR and should be collected/examined. There are also many geologically pertinent figures and tables here.

Golder Associates, October 1977, "Report to Gulf Interstate Engineering Co. on Geotechnical Study of Cote Blanche Island Salt Mine, New Iberia, Louisiana," Volume II, appendices.

The appendices to the Cote Blanche Island salt mine geotechnical study include the following geological sections: Appendix II - Geological report prepared by Dr. D. H. Kupfer (61 p. plus supplement). The report appears extremely detailed and thorough and contains an annotated bibliography; Appendix III - 0il exploration holes drilled through salt dome; Appendix IV - Logs for selected drill holes; Appendix V - Directional surveys for selected drill holes; Appendix VI - Results of salt quality analyses; Appendix VII - Petrographic and spectrographic test results; Appendix VIII - Drill hole logs; Appendices IX - Results of chemical tests on samples from "Yellow" salt zone; Appendix $X$ - Strength test results; 
Appendix XI - Longitudinal and shear wave velocities; Appendix XII - In situ tests to determine containment properties of salt; Appendix XIII Reconnaissance investigation of shafts; Appendix XIV - Laboratory permeability results; Appendix XV - Chemical analysis of water samples from Cote Blanche mine.

Golder Associates, December 1978, "Draft Report on Discussions Held in New Orleans on November 29 and December 1, 1978, Concerning Potential Problems with Underground $0 i 1$ Storage Caverns in Salt Domes," Volume I, Summary volume, $13 \mathrm{p}$.

It was proposed to reduce the pressure on the $0 i 1$ stored in caverns so that zero net pressure is attained at the surface. The aim of the meeting was to investigate adverse effects associated with depressurization, i.e. excessive closure of the cavern; structural instability of the roof, walls, or floor; damage to access holes and pumping equipment, surface subsidence; and loss or contamination of stored fluid. Methods suggested to assess cavern stability and depressurization effects include field measurements and tests as well as laboratory and numerical modelling. Suggested field measurements to monitor cavern stability were: (1) measurement of surface displacement, (2) sonar measurements, (3) pressure and volume measurements of fluids entering and leaving cavern, (4) borehole logs, (5) microseismic monitoring, (6) downhole deformation monitoring devices, (7) other downhole devices, (8) acoustic monitoring, (9) stress measurements, (10) cavern hydrodynamic studies. Site specific recommendations were made for West Hackberry Cavern Number 6, Bayou Choctaw Caverns Number 15 and 17, Bryan Mound Caverns Number 4 and 5, and Bryan Mound Cavern Number 2.

Golder Associates, December 1978, "Draft Report on Discussions Held in New Orleans on November 29, and December 1, 1978, Concerning Potential Problems with Underground $0 i 1$ Storage Caverns in Salt Domes," Volume II, Main text and figures, $34 \mathrm{p}$.

This report is somewhat more detailed than Volume I (Summary) and has more specific site recommendations. 
Gulf Coast Association of Geological Societies and the American Association of Petroleum Geologists, 1972, "Tectonic Map of Gulf Coast Region, U.S.A.."

The tectonic map is at a scale of 1:1,000,000 and has major faults, folds, salt diapirs and structure contours plotted.

Gulf Interstate Engineering Company, November 8, 1977, "Solution Cavern Certificates of Usability and Integrity for the Strategic Petroleum Reserve Program of the Department of Energy, West Hackberry Site," Book 2 of 2.

This report includes a certificate of cavern usability and integrity and a certificate of authority, questions to be resolved, results of tests, surveys, and remedial works, a summary of investigations and test results on cavern $\# 9$, cavern $\# 9$ statistics, and operating limitations. The supporting documentation on cavern $\# 9$ presented as exhibits are the casing and cavern test programs, cement bond logs, pressure recorder chart, certificate of calibration, sonar caliper brochure, sonar caliper survey, gyro azimuth and deviation survey, graphic representation of separation of cavern \#8 and \#9, casing caliper survey, and hydraulic calculations.

Gulf Interstate Engineering Company, May 27, 1978, "Solution Cavern Certificates of Usability and Integrity for the Strategic Petroleum Reserve Program of the Department of Energy, Bayou Choctaw Site."

This report includes certificates of cavern usability and integrity and a certificate of authority, a summary of investigations and test results of cavern \#20. The supporting documentation on cavern \#20 presented as exhibits are the casing and cavern test program, cement bond log, pressure recorder charts, certificate of calibration, sonar brochure, sonar calipher survey, gyro azimuth and deviation survey, casing caliper survey, temperature survey, hydraulic calculations, and miscellaneous drawings.

Gulf Interstate Engineering Company, May 1978, "As-Built Drawings for Bayou Choctaw Complex, Bryon Mound Complex, West Hackberry Complex, Sulphur Mines Complex."

The drawings show depth to the top of caprock and the top of salt, and construction details for wells at Bryan Mound, West Hackberry, Sulphur Mines, and Bayou Choctaw. Construction drawings of these wells are 
included: Bryan Mound - well in complex cavern \#1, storage wells in $\# 2$, \#4, and \#5; West Hackberry - storage well in \#6, re-entry well in $\# 6 \mathrm{~B}$, wel1 in \#7, \#8, and \#9, storage well \#11, disposal wells \#1 and \#2; Sulpher Mines - well in \#2, \#4, \#5, \#6X, \#6Y, \#7A, and \#7B, disposal well \#1; Bayou Choctaw - wel1 in \#1, \#2, \#3, \#8A, \#11, \#13, \#18, \#19, and \#20, disposal well \#1.

Gulf Interstate Engineering Company, May 8, 1978, "Solution Cavern Certificates of Usability and Integrity for the Strategic Petroleum Reserve Program of the Department of Energy, Bryan Mound Site."

This report includes a certificate of cavern usability and integrity and a certificate of authority, a summary of investigations and test results on cavern \#1B, and statistics on cavern \#5. The supporting documentation on cavern \#5 presented as exhibits are the casing and cavern test program, cement bond log, pressure recorder chart, certificate of calibration, sonar brochure, sonar caliper survey, gyro azimuth and deviation survey, casing and caliper survey, temperature survey, hydraulic calculations, and miscellaneous drawings. A copy of this report with the same title in DOE New Orleans office is on \#1B alone and has \#1B supporting documentation same as described for \#5 above.

Jirik, C. J., and Weaver, L. K., 1976, "A Survey of Salt Deposits and Salt Caverns, Their Relevance to the Strategic Petroleum Reserve," Federal Energy Administration Report FEA/S-76/310, $64 \mathrm{p}$.

Bedded salt and salt domes in the U.S. are discussed in terms of their potential for the storage of petroleum. Salient statistics are presented on on- and offshore salt domes in Texas, Louisiana, Alabama, and Mississippi. Since the 1940's, underground caverns have been used for storing liquified petroleum gases (LPG) and natural gas. Information on the LPG storage operations is summarized in tables. In 1975, there was potential space available for the storage of $304,667,000$ barrels of hydrocarbons in salt strata, salt domes, mines, and other reservoirs in 28 states; $93 \%$ of the storage capacity was in salt. 
Law Engineering Testing Company, July 15, 1977, "Report of Geotechnical Investigation, Bryan Mound Storage Site, Freeport, Texas."

The purpose of this geotechnical investigation was to determine the stratigraphy of the sub-surface materials at the site and to obtain data and information about the general character and properties of the subsurface materials to permit evaluation of foundation types and capacities for the proposed construction. This is basically a report on the suitability of soils to support facility foundations.

Louis Records and Associates, Inc., October 1978, "Well History, Brine Disposal Well \#4, Bayou Choctaw, Iberville Parish, Louisiana."

The report includes a narrative history, well, wellhead, and gravel pack schematics, depth versus days history, directional deviation survey, chronological log listing, cement slurry properties, sidewall core analysis, drilling fluid summary, casing and tubing report, comprehensive water analysis, Louisiana Conservation Department documents, location plat, and well logs (borehole geometry, gamma/cement bond, caliper, induction electrical, ISF/sonic, continuous directional).

Louis Records and Associates, Inc., November 1978, "Well History, Brine Disposal Well \#7, Bayou Choctaw, Iberville Parish, Louisiana."

The report includes a narrative history, well, wellhead, and gravel pack schematics, depth versus days history, directional deviation survey, chronological log listing, cement slurry properties, sidewall core analysis, drilling fluid summary, casing and tubing report, comprehensive water analysis, Louisiana Conservation Department documents, location plat, and well logs (caliper, gamma/cement bond, borehole geometry, compensated neutron density, induction electrical).

Louis Records and Associates, Inc., November 15, 1978, "Well History, Brine Disposal Well \#8, Bayou Choctaw, Iberville Parish, Louisiana."

The report includes a narrative history, well, wellhead, and gravel pack schematics, depth versus days history, directional deviation survey, 
chronological log listing, cement slurry properties, drilling fluid summary, casing and tubing report, comprehensive water analysis, Louisiana Conservation Department documents, location plat, and well logs (caliper, induction electrical, borehole geometry continuous directional, ISF/sonic).

Louis Records and Associates, Inc., August 16, 1978, "We11 History, Brine Disposal We 11 \#10, Bayou Choctaw site, Calcasieu Parish, Louisiana."

The report includes a narrative history, well and wellhead schematics, depth versus days history, directional deviation survey, chronological log listing, cement slurry properties, core analysis, drilling fluid summary, casing report, Louisiana Conservation Department documents, location plat, and well logs (borehole geometry, compensated neutron density, ISF/sonic, continuous directional, continuous dipmeter, caliper, cement bond, Cyberlook, SARABAND).

Louis Records and Associates, Inc., November 1978, "Well History, Brine Disposal Well \#11, Bayou Choctaw, Iberville Parish, Louisiana."

The report includes a narrative history, well, wellhead, and gravel pack schematics, depth versus days history, directional deviation survey, chronological $\log 1$ isting, cement slurry properties, drilling fluid summary, casing and tubing report, comprehensive water analysis, Louisiana Conservation Department documents, location plat, and well logs (caliper, borehole geometry, cement bond, induction electrical, laterolog).

Louis Records and Associates, Inc., December 28, 1978, "Tabular Listing of SARABAND, a Sandstone Analysis for Brine Disposal Well \#12, Bayou Choctaw," with SARABAND $\log$ and induction, neutron density, and sonic logs.

SARABAND (a Schlumberger computer processed log using induction, neutron, density, and sonic logs) is included in graphic and tabular form. The tabular printout is for depths between 5.952 .0 and $7938.0 \mathrm{ft}$ and includes permeability, porosity, water saturation, hydrocarbon density, clay volume, cumulative porosity, and cumulative hydrocarbons in depth increments of one foot. The individual logs are also included. 
Louis Records and Associates, Inc., Ju1y 29, 1978, "We11 History, Brine Disposal Well \#18, Bayou Choctaw Site, Calcasieu Parish, Louisiana."

The report includes a narrative history, well and wellhead schematics, depth versus days history, chronological log listing, casing report, and well logs (borehole geometry, differential temperature, acoustic cement evaluation).

Louis Records and Associates, Inc., January 1979, "We 11 History, Re-Entry We11 \#19A, Bayou Choctaw Site, Calcasieu Parish, Louisiana."

The report includes a narrative history, well and wellhead schematics, depth versus days history, directional deviation survey, chronological log listing, cement slurry properties, core analysis, drilling fluid summary, casing report, Louisiana Conservation Department documents, location plat, and well logs (caliper, compensated density, induction electrical, gamma/cement bond).

Louis Records and Associates, Inc., September 15, 1978, "Well History, WorkOver Well \#20, Bayou Choctaw Site, Calcasieu Parish, Louisiana."

The report includes a narrative history, well and wellhead schematics, depth versus days history, chronological log listing, casing report, and caliper $10 \mathrm{~g}$.

Louis Records and Associates, Inc., January 3, 1979, "Operations Manua1, Bryan Mound Disposal Wells."

Information is provided for brine disposal wells \# $7,1 \mathrm{~A}, 2 \mathrm{~A}, 2 \mathrm{~B}$, and $3 \mathrm{~A}$ and includes well, wellhead, and gravel pack schematics, location plat, and injection zone section of ISF/sonic log.

Louis Records and Associates, Inc., November 1978, "Workover Summary, Cavern We11 \# ], Bryan Mound, Brazoria County, Texas."

The report includes a narrative history, well and wellhead schematics chronological log listing, cement slurry properties, casing and tubing report, Texas RR Commission documents, cement bond $\mathrm{log}$ and electromagnetic thickness tool log. 
Louis Records and Associates, Inc., November 1978, "We11 History, Brine Disposal Well \#1A, Bryan Mound Site, Bryan Mound, Texas."

The report includes a narrative history, well and wellhead schematics, depth versus days history, directional deviation survey, chronological log listing, cement slurry properties, core analysis, drilling fluid summary, casing report, Texas RR Commission documents, location plat and well logs (caliper, cement bond, ISF/sonic, compensated neutron density, continuous dipmeter, acoustic cement evaluation).

Louis Records and Associates, Inc., July 21, 1978, "We11 History, Brine Disposa1, We11 2A, Bryan Mound Site, Bryan Mound, Texas."

The report includes a narrative history, well and wellhead schematics, depth versus days history, directional deviation survey, chronological $\log$ listing, cement slurry properties, core analysis, drilling fluid summary, casing report, Texas RR Commission documents, location plat, and wel1 logs (ISF/sonic, compensated neutron density, perforated depth control, cement bond, caliper, borehole geometry, continuous dipmeter, acoustic cement evaluation).

Louis Records and Associates, Inc., December 1978, "We11 History, Brine Disposal, We11 \#2B, Bryan Mound, Brazoria County, Texas."

The report includes a narrative history, well, wellhead, and gravel schematics, depth versus days history, directional deviation surveys, chronological log listing, cement slurry properties, drilling fluid summary, casing and tubing report, Texas RR commission documents, location plat, and geophysical logs (ISF/sonic, caliper, cement bond, continuous dipmeter, compensated neutron density, microelectrical, induction electrical, acoustic cement bond).

Louis Records and Associates, Inc., August 4, 1978, "Well History, Brine Disposal, Wel1 \#3A, Bryan Mound Site, Bryan Mound, Texas."

The report includes a narrative history, well and wellhead schematics, depth versus days history, directional deviation survey, chronological log listing, cement slurry properties, core analysis, drilling fluid 
Louis Records and Associates, Inc., 1978, "Well History, Brine Disposal We 11 \#1C, West Hackberry Field, Cameron Parish, Louisiana."

The report includes a narrative history, well and wellhead schematics, depth versus days history, directional deviation survey, chronological log listing, cement slurry properties, core analysis, drilling fluid summary, casing report, Louisiana Conservation Department documents, locations plat, and well logs (gamma, cement bond, borehole geometry, compensated neutron density, ISF/sonic, cement bond/gamma, continuous directional, SARABAND).

Louis Records and Associates, Inc., 1978, "We11 History, West Hackberry Field, Brine Disposal Well \#2A."

The report includes a narrative history, well and wellhead schematics, depth versus days history, directional deviation survey, chronological log listing, cement slurry properties, core analysis, drilling fluid summary, casing report, Louisiana Conservation Department documents, location plat, and well logs (compensated neutron density, ISF/sonic, borehole geometry, acoustic cement evaluation, continuous dipmeter, continuous directional, SARABAND).

Louis Records and Associates, Inc., December 1978, "Well History, Brine Disposal Well \#2B, West Hackberry, Cameron Parish, Louisiana."

The report includes a narrative history, we 11 , well head, and gravel pack schematics, depth versus days history, directional deviation survey, chronological log listing, cement slurry properties, sidewall core analysis, drilling fluid summary, casing and tubing report, comprehensive water analysis, Louisiana Department of Conservation documents, location plat, and well logs (caliper, induction electrical gamma, cement bond, continuous directional).

Louis Records and Associates, Inc., "Well History, West Hackberry Field, Brine Disposal Well \#2C."

The report includes a narrative history, well and wellhead schematics, depth versus days history, directional deviation survey, chronological 
summary, casing report, Texas RR commission documents, location plat, and well logs (caliper, borehole geometry, compensated neturon density, ISF/sonic, perforated depth control, acoustic cement evaluation, continuous dipmeter, SARABAND).

Louis Records and Associates, Inc., October 1978, "We11 History, Brine Disposal Well \#3B, Bryan Mound, Brazoria County, Texas."

The report includes a narrative history, well, well head and gravel pack schematics, depth versus days history, directional deviation survey, chronological log listing, cement slurry properties, sidewall core analysis, drilling fluid summary, casing and tubing report, water analysis, Texas RR Commission documents, location plat, and well logs (cement bond, caliper, compensated neutron density, continuous directional, ISF/sonic, continuous dipmeter).

Louis Records and Associates, Inc., January 1979, "Workover Well History, Brine Disposal Well \#1, West Hackberry, Cameron Parish, Louisiana."

The report includes a narrative history, well, wellhead, and gravel packs schematics, completion report, previous well schematic, electric log section, chronological log listing, tubular report, comprehensive water analysis, Louisiana Department of Conservation documents, gamma log.

Louis Records and Associates, Inc., January 1, 1979, "Well History, Brine Disposal Well \#1A, West Hackberry Field, Cameron Parish, Louisiana."

The report includes a narrative history, well and wellhead schematics, depth versus days history, directional deviation survey, chronological log listing, cement slurry properties, core analysis, drilling fluid summary, casing report, Louisiana Conservation Department documents, location plat, and well logs (ISF/sonic, borehole geometry, compensated neutron density, continuous directional, continuous dipmeter, acoustic cement evaluation). 
log listing, cement slurry properties, core analysis, drilling fluid summary, casing report, Louisiana Conservation Department documents, location plat, and well logs (compensated neutron density, ISF/sonic, borehole geometry, acoustic cement evaluation, acoustic cement bond/gamma, continuous directional).

Louis Records and Associates, Inc., December 1978, "Well History, Brine Disposal We 11 \#2D, West Hackberry, Cameron Parish, Louisiana."

The report includes a narrative history, well, well head, and gravel pack schematics, depth versus days history, directional deviation survey, chronological log listing, cement slurry properties, sidewall core analysis, drilling fluid summary, casing and tubing report, comprehensive water analysis, Louisiana Department of Conservation documents, location plat, and well logs (caliper, borehole geometry, cement bond, gamma, compensated neutron density, induction electrolog, directional survey, continuous directional).

Lou is Records and Associates, Inc., December 1978, "Well History, Brine Disposal We1l \#2E, West Hackberry, Cameron Parish, Louisiana."

The report includes a narrative history, well, well head, and gravel pack schematics, depth versus days history, directional deviation survey, chronological log listing, cement slurry properties, sidewall core analysis, drilling fluid summary, casing and tubing report, comprehensive water analysis, Louisiana Department of Conservation documents, location plat, well logs (caliper, cement bond, induction electrolog, borehole geometry, continuous directional).

Louis Records and Associates, Inc., "Well History, Work-over Well \#6B, West Hackberry Field, Cameron, Parish, Louisiana."

The report includes a narrative history, well and wellhead schematics, directional deviation survey, chronological log listing, drilling fluid summary, casing report, location plat, and well logs (perforating and collar, acoustic cement evaluation). 
Louis Records and Associates, Inc., "Well History, Re-entry Well \#6C, West Hackberry Field, Cameron Parish, Louisiana."

The report includes a narrative history, well and wellhead schematics, depth versus days history, directional deviation survey, chronological $\log$ listing, cement slurry properties, core analysis, drilling fluid summary, casing report, Louisiana Conservation Department documents, location plat, and well logs (borehole geometry, cement bond, continuous directional, induction spherically focused).

Louis Records and Associates, Inc., "Well History Work-over Well \#7, West Hackberry Field, Cameron Parish, Louisiana."

The report includes a narrative history, well and wellhead schematics, depth versus days history, chronological log listing, cement slurry properties, casing report, and well logs (caliper, acoustic cement evaluation).

Louis Records and Associates, Inc., "Well History Re-entry Well \#7A, West Hackberry Field, Cameron Parish, Louisiana."

The report includes a narrative history, well and wellhead schematics, depth versus days history, directional deviation survey, chronological log listing, cement slurry properties, core analysis, drilling fluid summary, casing report, Louisiana Conservation Department documents, location plat, and well logs (borehole geometry, acoustic cement evaluation, continuous directional, induction spherically focused).

Louis Records and Associates, Inc., "Well History, Re-entry Well \#7B, West Hackberry Field, Cameron Parish, Louisiana."

The report includes a narrative history, well and wellhead schematics, depth versus days history, directional deviation survey, chronological $\log$ listing, cement slurry properties, core analysis, drilling fluid summary, casing report, Louisiana Conservation Department documents, location plat, and well logs (acoustic cement evaluation, borehole geometry, continuous directional, induction spherically focused). 
Louis Records and Associates, Inc., "We11 History, Re-entry Well \#8A, West Hackberry Field, Cameron Parish, Louisiana."

The report includes a narrative history, well and wellhead schematics, depth versus days history, directional deviation survey, chronological log listing, cement slurry properties, core analysis, drilling fluid summary, casing report, Louisiana Conservation Department documents, location plat and well logs (ISF/sonic, compensated formation density, borehole geometry, caliper, continuous directional, acoustic cement evaluation).

Louis Records and Associates, Inc., "Well History, Re-entry Well \#8B, West Hackberry Field, Cameron Parish, Louisiana."

The report includes a narrative history, well and wellhead schematics, depth verus days history, directional deviation survey, chronological $\log$ listing, cement slurry properties, core analysis, drilling fluid summary, casing report, Louisiana Conservation Department documents, location plat, and well logs (acoustic cement evaluation, borehole geometry, continuous directional, ISF/sonic).

Louis Records and Associates, Inc., "Wel1 History, Work-over Well \#9, West Hackberry Field, Cameron Parish, Louisiana."

The report includes a narrative history, well and wellhead schematics, depth versus days history, chronological log listing, cement slurry properties, casing report, and well logs (borehole geometry, acoustic cement evaluation).

Louis Records and Associates, Inc., "Well History, Re-entry Well \#9A, West Hackberry Field, Cameron Parish, Louisiana."

The report includes a narrative history, well and wellhead schematics, depth versus days history, directional deviation survey, chronological $\log 1$ isting, cement slurry properties, core analysis, drilling fluid summary, casing report, Louisiana Conservation Department documents, location plat, and well logs (acoustic cement evaluation, caliper, continuous directional, induction spherically focused). 
Louis Records and Associates, Inc., "Well History Re-entry Well \#9B, West Hackberry Field, Cameron Parish, Louisiana."

The report includes a narrative history, well and wellhead schematics, depth versus days history, directional deviation survey, chronological log listing, cement slurry properties, core analysis, drilling fluid summary, casing report, Louisiana Conservation Department documents, location plat, well logs (acoustic cement evaluation, caliper, compensated formation density, continuous directional, ISF/sonic).

Louis Records and Associates, Inc., December 1978, "Wel1 History, Re-entry We11 \#11A, West Hackberry, Cameron Parish, Louisiana."

The report includes a narrative history, well and wellhead schematics, depth versus days history, directional deviation survey, chronological log listing, cement slurry properties, drilling fluid summary, casing and tubing report, Louisiana Department of Conservation Documents, 1ocation plat, well logs (cement bond, caliper, directional survey, induction electrolog, computed diplog).

Magorian, T. R. November 1978, "Geotechnical Study, Bayou Choctaw, Brine Disposal Reservoir Analysis (proposed expansion)," Consultant's report to U.S. Department of Energy, Strategic Petroleum Reserve Program.

In this report sands with maximum brine injectivity rate and volume were identified from geophysical data and reservoir analysis to be located near the base of the Miocene section. Sand catalogs for each storage site were prepared and are included; faults which may affect disposal operations are shown on accompanying maps $\left(1^{\prime \prime}=2000^{\prime}\right)$. Additional disposal wells are recommended and deep drilling is suggested below $7000 \mathrm{ft}$ to test the massive Miocene sands.

Magorina, T. R., November 1978, "Geotechnical Study, Bryan Mound, Brine Disposal Reservoir Analys is (Containment), "Consultant's report to U.S. Department of Energy, Strategic Petroleum Reserve Program.

In this report sands with maximum brine injectivity rate and volume were identified from geophysical data and reservoir analysis to be 
located near the base of the Miocene section. Sand catalogs for each storage site were prepared and are included; faults which may affect disposal operations are shown on accompanying maps $\left(1^{\prime \prime}=2000^{\prime}\right)$. The possibility of leakage upward through faults from the Bryan Mound \#1 disposal well was investigated and evidence of a seal was found.

Mahtab, M. A., Lamb, D. W., Van Sambeek, L. L., and Gi11, S. D., 1978, "National Strategic Crude 0il Storage in Weeks Island Dome Salt Mine: I. Geotechnical Evaluation," Amer. Soc. Mech. Engr. 78-Pet-75.

Geologic features which were examined at the Weeks Island mine of interest to the SPR program were: 1) zones of vertical banding and folding, 2) shear zones, 3) blowouts. The salt tested impermeable and brine, 0il, and gas leaks are thought to be only local. The pillars exhibited varying degrees of spalling and the roof showed no signs of stress or failure. The facility was therefore certified as suitable for crude oil storage.

Parsons-Gilbane, 1978, "Activities of the Technical Committee, Strategic Petroleum Reserve Program, February 1978, November 1978," Job No. 5822-1001.

This document contains the following reports: TR-1-Weeks Island Mine Rehabilitation; TR-2-Bayou Choctaw Brine Disposal by Deviated Drilling; TR-3-Weeks Island Service Shaft Pipe Installation; TR-4-Overview-Explosion Hazard Control, SPR Program; TR-5-Brine Disposal, Overview and Analysis, Interim Reports \#1, 2, and 3; TR-6-Weeks Island Mine, Flotable Trash; TR-7-Inerting Weeks Island Atmosphere; TR-8-Weeks Island Cost Reduction Team; and 13 progress reports.

Parsons-Gilbane, August 15, 1978, "Brine Disposal, Analysis and Overview, Technical Committee, Strategic Petroleum Reserve."

The report looks at brine disposal options for the Bryan Mound, Bayou Choctaw and West Hackberry sites because of previous unsatisfactory brine injection rates experienced in the SPR program. Pretreatment methods of the brine are considered such as the removal of suspended solids, oxygen, and ion and $\mathrm{pH}$ control. The nature of the problems encountered with disposal wells at the three SPR sites were attributed to self imposed and start-up problem, improper completion procedures and incorrect downwe 11 design. 
Parsons-Bilbane, August 30, 1978, "Brine Disposal, Analysis and Overview, Interim Report 2, Technical Committee, Strategic Petroleum Reserve."

The report contains the minutes from the technical meeting held August 23 and 24, 1978 and a list of recommendations drawn up at the meeting. A brine disposal monitor is suggested for each site. A change in brine pond design is recommended for Bayou Choctaw as pretreatment for the high solid content. Short-term improvements in disposal operations at Bryan Mound are suggested such as the cleaning of the brine surge/storage pond to prevent sediment from clogging injection formations and procedures to prevent barium sulfate precipitation. Good injection rates at West Hackberry should be attained if correct brine handling and disposal procedures are adhered to. Chemical analyses of brine samples from Bryan Mound and Bayou Choctaw are included in the Appendices.

Parsons-Gilbane, October 10, 1978, "Brine Disposal, Analysis and Overview, Interim Report 3, Technical Committee, Strategic Petroleum Reserve."

The report contains the minutes from the September 12 and 13, 1978, technical meeting. Procedures for upgrading injection well capacity are listed, the brine disposal activities at Bryan Mound, Bayou Choctaw and West Hackberry are reviewed and guidelines for later disposal systems are considered. A study by N.W. Snyder on the solubility of calcium sulfate in brine and a discussion of on-site sampling and water quality at Bayou Choctaw by B. I. Loran is included. Brine disposal status reports, chemical analyses of brines, and drawings for upgrading the brine pond at Sulphur Mines are in the Appendices.

PB/KBB, January 1978, "Strategic Petroleum Reserve Facility, Bryan Mound, Texas, Supplemental Geotechemical Report."

This supplemental report was necessitated by alterations in the design and a few information gaps in the original geotechemical report by Law Engineering. Law Engineering Testing Company was contracted as part of the present study to drill two borings and perform laboratory tests to provide design recommendations for two relocated storage tanks. In-situ 
seismic tests were also performed in order to determine the shear modulus of the soil for the design of pump foundations. The Appendix contains the boring plan, Atterbery limit test summary, consolidation test results, letter from Law Engineering and an analysis from M. T. Davisson, foundation engineer.

PB/KBB, August 21, 1978, "Strategic Petroleum Reserve Program, Salt Dome Study, Sulphur Mines, Louisiana," PMTPO \#924.

Recommendations are made for the use of each of the caverns in the Sulphur Mines dome for crude oil storage. These items were considered in the assessment: cavern stability, continued brining, cavern coalescense, cavern shape, crude oil cycling, cavern proximity to edge of dome and adjacent caverns. The geological section is very general with little site-specific information. Dome cross-sections show the top of the caprock and salt but give no information on surrounding sediments. In the drilling evaluation it is stated that voids produced by sulphur mining operations and associated rock falls and subsidence have resulted in loss of circulation during drilling.

PB/KBB with Louis Records and Associates, Inc., August 1978, "Final Report, Salt Dome Geology and Cavern Stability Analysis, Bayou Choctaw, Louisiana," (appendix annotated separately) PMTPO \#919.

The project included the review of existing geologic studies, geologic field investigations (including drilling and coring), and laboratory testing of rock cores. The caprock was found to be composed primarily of gypsum, highly weathered and with closely spaced joints. A cavity was found at the caprock salt interface in one core hole and two cavities were found in the upper $100 \mathrm{ft}$ of the salt in the other corehole, causing drilling problems related to lost circulation. Gas was also encountered in drilling and small amounts of oil. Recommendations for cavern utilization are presented. Basic data for Bayou Choctaw presented in the report are: salt ultrasonic velocities, (core 1), salt moisture contents and bulk densities (core 1), salt strength and elastic properties (core 1), 
caprock moisture contents and bulk densities (cores 1 and 2), caprock strength and elastic properties (cores 1 and 2); initial elevations of subsidence monuments; cavern and brine well summary including date drilled, depth of well, depth of top of cavern, gross volume, present status and remarks; structure contour map (1000' contour interval). Nine geologic cross-sections (define salt and caprock limits but no information on surrounding sediments or structure; also define caverns with date of sonar survey given); $\log$ of core hole No. 1 including drilling operations log, geological log, S.P., caliper, conductivity, resistivity, gamma, potential, velocity, neutron logs; log of core hole No. 2 including potential, resistivity, velocity, gamma, neutron logs; location plat for subsidence movements with topographic contours drawn on a one foot contour interval.

PB/KBB with Louis Records and Associates, Inc., August 1978, "Appendix to Final Report, Salt Dome Geology and Cavern Stability Analysis, Bayou Choctaw, Louisiana." PMTPO \#919.

A field survey was made to assess the presence or absence of a major depression of approximately 300 meter amplitude in the salt surface at Bayou Choctaw dome. Models developed postulate thickening or thinning of the caprock and each give plausible results. The conclusion reached is that the anomaly results from caprock properties and not a depression. Tests conducted and reports included are as follows: microgravity survey (Weston Geophysical Corporation); report on laboratory testing of the physical properties of the salt and caprock drill core (Dames \& Moore); geologic description and interpretation of field and rock core studies (Alfred J. Hendron, Jr., Geotechnical Engineer); mineralogical examination of caprock cores (R. E. Ferrell, Jr., .Consulting Geologist); structure of the west flank (R. L. Thomas, Consulting Engineer); anhydritecrude oil correlation (Carbon Systems, Inc.); numerical analyses of Bayou Choctaw salt dome and cavern No. 4 (R. L. Thoms and R. M. Gehle); and elastic and time dependent finite element analyses of DOE-SPR caverns at Bayou Choctaw (J. Ghaboussi, A. J. Hendron, Jr., and R. Ranken). 
PB/KBB, September 6, 1978, "Strategic Petroleum Reserve Program, SPR Conceptual Design, Supplement to Salt Dome Geology and Cavern Stability Analysis, Bayou Choctaw, Louisiana." LTC \#98

This is an engineering report and contains no geological data.

PB/KBB, January 25, 1979, "Strategic Petroleum Reserve Program, Cavern \#3, Investigation, Scope of Work, Bryan Mound, Texas," LTC \#396.

Fluid levels in cavern \#3 fluctuate as much as $450 \mathrm{ft}$ leading to the conclusion that there is a significant exchange of fluid with the surrounding aquifers. The scope of work outlined is for cavern logging and sampling, monitoring of fluid level and properties, and study of the sonar survey. Maps included here are cavern \#3 contour maps (10 ft contour interval plus one 5-ft interval), a Freeport Sulphur Company map updated to $1935\left(7^{\prime \prime}=200^{\prime}\right)$ with depths of wells and depths to top of salt shown.

Science Applications, Inc., July 25, 1977, "Assessment of the Impact of the Use of Shallow Aquifers for Brine Disposal at Bayou Choctaw," SAI-78-642-HU.

A comparison was made of the environmental risks associated with the use of shallow $\left(2000-3000^{\prime}\right)$ salt water aquifers and deep (6000') aquifers. for brine disposal at Bayou Choctaw. The potential problems are aquifer fracturing from excessive injection pressure, leakage through other operational or abandoned wells, and interference with nearby oil and gas operations. The study shows that both deep and shallow aquifers are acceptable. The shallower ones are more attractive for injection but a monitoring system is essential to safeguard Baton Rouge's fresh water aquifers. The extent of the shallow aquifers are shown on maps as are the major faults in the area. The study was prepared by Charles T. Smith and William J. Bernard of LSU as consultants to SAI. The list of references is also pertinent to site hydrology.

Science Applications, Inc., October 28, 1977, "Site Environmental Action Report, Bayou Choctaw."

Geological and hydrological impacts specified are channel erosion due to increased barge traffic in Bull Bay, possible surface subsidence over 
storage caverns, possible fracture of the aquiclude above and below the disposal aquifer due to high brine injection pressures, cavity collapse between caverns \#15 and \#17, blowouts from the 19 abandoned we11s if they are unplugged or improperiy plugged, and oil spills. The geological and hydrological sections combined are about two pages long in this report (p. B-33, 37-38).

Serata, S. 1978, "Geomechanical Basis for Design of Underground Salt Cavities," Amer. Assoc. Mech. Engr. 78-Pet-59, 43 pp.

Three basic geomechanical problems must be solved in designing salt caverns for the storage of crude oil: 1) numerical representation of the brittle-ductile properties of rock salt, 2) computer simulation of long-term behavior of salt cavities, and 3) vertification of the model. These problems have been approached by defining the material properties of rock salt and developing the rheological finite element (REM) computer simulation method. The salt cavity design for LOOP is used in the model.

Sonic logs for brine disposal wel1s \#1, \#1-A, \#1-C, \#2, \#2-C, \#2-D, and \#2E, West Hackberry and \#2-A, East Hackberry.

The sonic logs are correlated on a large chart with potential brine disposal horizons marked in blue and actual brine disposal horizons marked in green.

Sonic logs for brine disposal we17s \#1, \#2, \#3, \#4, \#6, \#7, \#10, Bayou Choctaw. The sonic logs are correlated on a large chart with possible brine disposat horizons indicated in red.

U.S. Department of Energy, December 1977, "Strategic Petroleum Reserve, Final Environmental Impact Statement (Final Supplement to FEA FES 76/77-6), Bryan Mound Salt Dome, Brazoria County, Texas. DOE/EIS-000T.

This final supplement to the Bryan Mound final Environmental Impact Statement addresses the brine injection well system and the water intake system. The geological discussion is not detailed; it includes the chemical composition of the brine, the soils, Brazos River hydrological data 
(sediment analyses and water quality), impact of construction and operation of injection and intake on the geology. Many of the conclusions dealing with the impact of injection are neither supported nor referenced.

U.S. Federal Energy Administration, January 1977, "Strategic Petroleum Reserve, Final Environmental Impact Statement for Cote Blanche Mine," FEA/S-77/016, FES $76 / 77-7$.

The EIS contains a good regional characterization of the geology (16 pages) and hydrology and sedimentation (45 pages) of the cote Blanche mine. The information is summarized from previous reports and is well referenced, but is large scale and there is little if any data site specific to the mine. The impact of geology, mineral resources and hydrology is virtually dismissed with almost no supporting evidence.

U.S. Federal Energy Administration, January 1977, "Strategic Petroleum Reserve, Final Environmental Impact Statement, West Hackberry Salt Dome," FEA/S-76/503, FES $76 / 77-4$.

The geology section is brief and summarized from previous reports. A structure contour map (100-ft contour interval) drawn on the top of the caprock, and an isopach map drawn on the thickness of the caprock are included but no control points are plotted. There are two geologic cross-sections and a structure map of the dome showing the location of oil and gas wells. The two geologic influence addressed are channel erosion due to increased barge traffic in Alkali Ditch and cavern collapse and subsidence. The only hydrologic impacts considered are on water quality.

U.S. Federal Energy Administration, May 14, 1976, "Draft of Engineering and Cost Study of the Bryan Mound Storage Complex, Brazoria County, Texas."

The geology text of this report is less than one page long. The structure contour map on the top of the salt is drawn on a 50-ft contour interval.

U.S. Federal Energy Administration, 1977, "Site Selection Decision Paper, Bryan Mound."

The question posed is whether Bryan Mound is suitable for the Early Storage Reserve program (ESR). The report contains no basic geologic 
data and provides just a brief summary of the geology (p. 4-5; Appendix A, p. 1). The main geological concern is that the dome is structually sound to prevent the loss of oil; structural soundness is concluded without references or supporting data in the report. There are indications that there would be a high risk of cavern casing problems because of hot sulfur water in the caprock. The report states that in general caprock faulting is associated with piercement-type salt domes but "these faults have no effect on the storage characteristics of the dome since salt behaves as a plastic material" and heals. Nothing specific to Bryan Mound is stated about faulting. The environmental risks (p. 8-9) associated with disposing of brine in wells are discussed. The major risks mentioned are aquifer fracture, the possibility of fresh water contamination, and interference with oil and gas production.

U.S. Federal Energy Administration, January 1977, "Strategic Petroleum Reserve, Final Environmental Impact Statement, "Bryan Mound Salt Dome, "FEA/S-76/502, FES 76/77-6.

The report contains a generalized section on geology ( 4 pages) and also some ground water information ( 6 pages). Possible subsidence was the only geologic impact mentioned as being significant, (2 pages; Appendix I). It is stated here that brine discharged from the cavities would be used by Dow Chemical.

U.S. Federal Energy Administration, August 1977, "Strategic Petroleum Reserve, Supplement to Final Environmental Impact Statements for Weeks Island/Cote Blanche Mines," FEA/S-77/228, Supplement to FES-76/77-7 and FES 76/77-8.

This supplement is concerned with the construction and operation of the revised oil distribution system. The geological section is minor and no basic geological data is presented. In the report the reader is referred to FES-76/77-7 and FES 76-77-8.

U.S. General Accounting Office, August 14, 1978, "Report to the Congress of the United States, Questionable Suitability of Certain Salt Caverns and Mines for the Strategic Petroleum Reserve," EMD-7865.

GAO says that SPR time constraints and the technical nature of the program have resulted in an inadequate analysis of risks. The report 
emphasizes safety factors and sites the Mining, Safety and Health Administration (MSHA) report. The report presents no basic geological data but brings up geological problems.

Van Sambeek, L. L., F. P. Hansen, F. P. Gnirk, and A. A. Mahtab, 1978, "National Strategic Crude $0 i 1$ Storage in the Weeks Island Dome Salt Mine: II. Rock Mechanics Evaluation," Amer. Assoc. Mech. Engr., 78-Pet-84.

This rock mechanics study was performed to assess the structural stability of old mine workings in relation to Morton Salt Company's proposed new deeper mine. Laboratory experiments were performed on the salt to determine strength and deformation characteristics. From these tests it was determined that a $300-\mathrm{ft}(90 \mathrm{~m})$ minimum thickness should be maintained between the old and new workings but the possibility of blowouts has not been addressed in the study.

Hawkins, M. E. and C. J. Jirik, 1966. Salt Domes in Texas, Louisiana, Mississippi, Alabama and Offshore Tidelands: A Survey; U.S. Bur. Mines Info. Circ. 8313, 78 pp.

A survey of 329 domes was made in the Gulf Coast Embayment. Brief descriptions of solution mining and conventional mining is given. $0 i 1$ and sulfur production are described. 


\section{APPENDIX B}

\section{SOLUTION MINING TECHNIQUE}

Alfred $H$. Medley

Fenix and Scisson, Inc.

A review taken from Fenix and Scisson, Inc., Final Report, Project I, Investigation of

New Leached Caverns, May 1976

(Reproduced with Permission

of Fenix and Scisson, Inc.) 
SOLUTION MINING TECHNIQUE

\section{STORAGE CAVERN - BACKGROUND}

An oil storage cavern is basically a large subterranean pressure vessel, connected to the surface by at least two vertical pipelines. In the case of a solution mined facility, the vessel usually contains both oil and brine. If oil is pumped into one of the pipelines, brine will come out of the other (or vice versa). Because oil will float on brine, the oil pipeline must connect to the top of the vessel and the brine line must connect to the bottom.

In bedded salt formations, it is sometimes possible to join two separate bore holes by inducing a hydraulic fracture between the holes along the base of the salt. If the cavern is leached by consistent injection of raw water into one hole while displacing brine from the other, the cavern will develop upward around the hole receiving the raw water. Thus in the finished cavern, the raw water hole will serve as the vertical pipeline to the top of the cavern and the brine hole will serve as the vertical pipeline to the bottom of the cavern (see Figure B.1).

Although the fracture connection process for leaching can be practical where caverns must be constructed in thin beds of salt, it is a fairly risky and costly procedure and is seldom attempted in thick zones. In fact, it is virtually impossible to induce a horizontal hydraulic fracture in a salt dome. Consequently, most salt dome caverns use only one borehole through which one or more pipes are suspended from surface.

Thus, a completed salt dome cavern usually has a cased borehole terminating at the roof of the cavern and a suspended pipe terminating near the floor. Water or brine is inserted into the suspended pipe to displace oil upward through the borehole annulus during withdrawal of oil from storage. During filling, oil is pumped into the annulus forcing brine to surface through the suspended pipe (see Figure B.1).

Most commercial caverns are operated by brine displacement of product and require a brine storage pit equal in volume to the cavern. Since the 


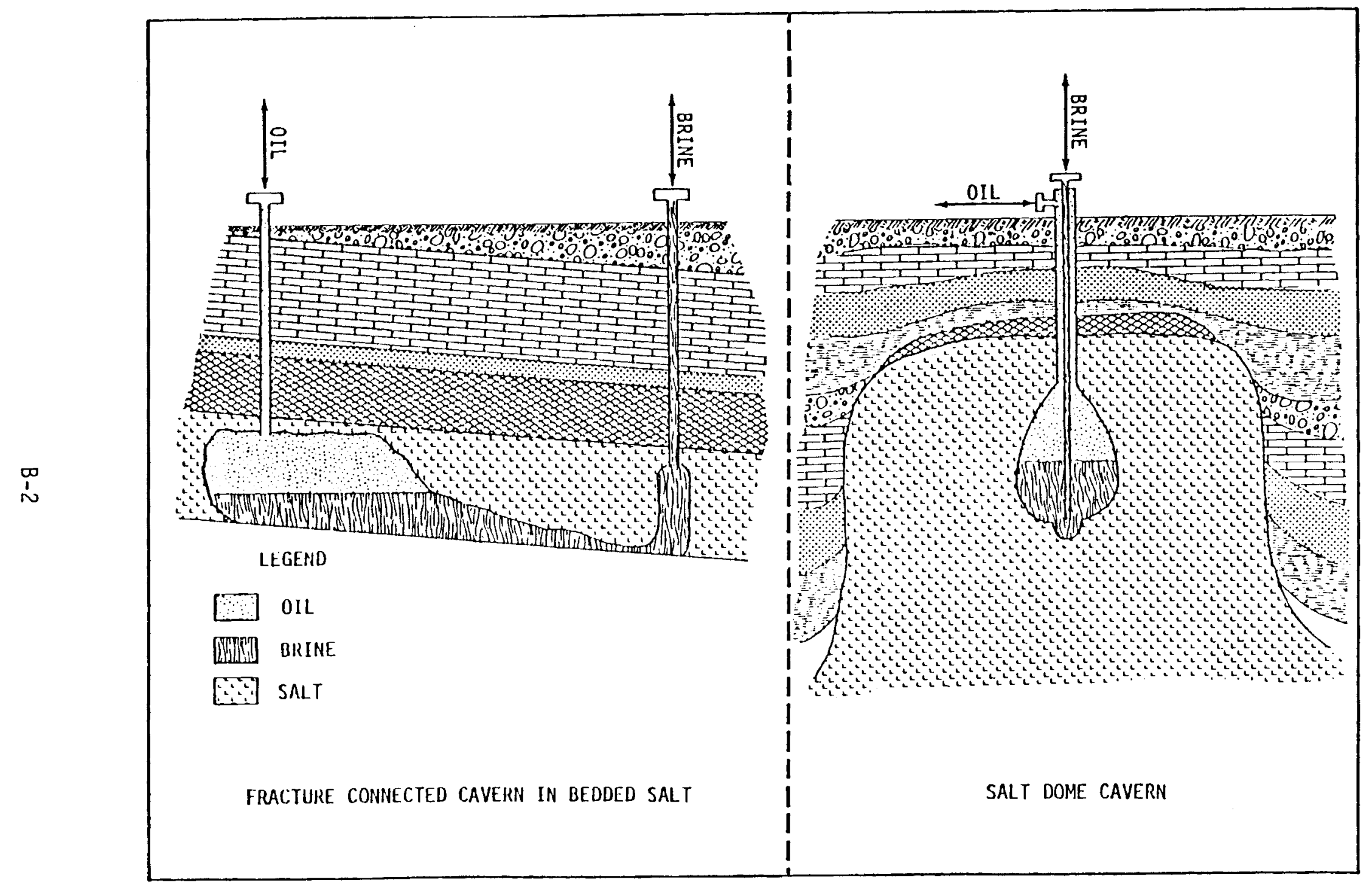

FIGURE B.1. Two Types of Storage Caverns 
brine is saturated with salt, no cavern growth occurs during product displacement and storage cycles may be repeated as frequently as required. It is also possible, however, to use fresh water or weak brine for displacement.

Many operators will use fresh water displacement in small caverns, allowing growth to occur each time product is recovered. When the cavern reaches its optimum size the system is switched to saturated brine displacement. In this way, construction of an expensive brine pit can be postponed and low cost additional storage space can be developed. 
$=$

.

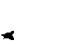




\section{SIZE RELATIONSHIP - BOREHOLE VERSUS CAVERN}

Salt dome caverns are usually leached through single boreholes. The size of those boreholes has a significant effect on both the rate of cavern development and on the usefulness of the completed caverns. Many commercial caverns storing LPG could meet operating requirements through cased boreholes as small as nine inches, yet have been developed through holes as large as $121 / 2$ inches to facilitate rapid leaching.

Occasionally, requirements are reversed. For example, oil storage caverns required for a supertanker facility proposed by LOOP Inc. could be leached through 22-inch holes but would need 60-inch holes to meet oil delivery requirements. (LOOP plans to use multiple 22-inch holes per cavern rather than a single 60-inch hole.)

The proposed strategic storage system presents a unique combination of criteria. Unlike commercial facilities, the stored product will rarely, if ever, be cycled. (The FEA has directed that caverns be designed to tolerate enlargement caused by fresh water displacement of oil during five cycles of storage. However, the mere existence of stored oil would reduce the likelihood that another embargo would be imposed, suggesting the possibility that only one cycle of storage will be required.)

The basic objective is to develop the cheapest possible system capable of delivering $i$ ts contents within a period of 150 days. Since solution mining is very sensitive to scale, this objective could be achieved by developing each cavern to the maximum capacity that could be emptied through its borehole during the prescribed period. The obvious question then becomes: Is there any limit on either borehole or cavern size?

A 60-inch diameter hole could be constructed into most of the subject domes using "big hole" drilling technology developed for the nuclear weapons testing program. Such a hole would be capable of emptying a 360 million barrel cavern in 150 days. Presumably, a 360-million barrel cavern could be leached. One possible configuration achieving that volume would approximate a cylinder 1,500 feet high with a diameter of 1,308 feet. 
Whether or not a 360-million barrel cavern could be constructed is of little more than academic interest at this time. In order to receive public acceptance and to expedite regulatory approval, the strategic storage cavern design must be based on proven technology.

Salt dome storage caverns are normally constructed in sizes ranging from several hundred thousand barrels to several million barrels of space. Many factors have affected the choice of size but limitations on fill and withdrawal time have usually dominated. For any given set of hole parameters, there is a maximum fill rate and withdrawal rate that can be achieved. Once those maximum rates are reached, the times required to fill or empty a cavern become direct functions of the cavern size. Frequently, an operator will pay a premium to construct a system of small caverns rather than one large cavern, thereby achieving the capability of storing products of different specification and/or ownership. He also limits the risk of total shutdown should a cavern develop operational problems and require remedial work.

Since there are no very large storage caverns, we turned to brine production wells in our search for examples of existing large caverns. We selected a limit of 20 million barrels for the final cavern, a size approximately equivalent to the largest salt dome caverns now used for brine production. We then computed the initial cavern size that would permit five cycles of storage without exceeding 20 million barrels and chose an initial volume of 10 million barrels. (A 10 million barrel cavern cycled five times with fresh water and refilled each time with 10 million barrels of $0 i 1$ would grow to a size of about 18.6 million barrels. If refilled to its maximum capacity after each cycle, it would grow to about 22.1 million barrels.)

Because of the FEA criterion that a cavern would be refilled only to its original capacity after each storage cycle, the borehole delivery requirement would be only 10 million barrels in 150 days, regardless of how large the cavern grew. We found that this objective could be achieved through a 15-inch cased borehole at all of the prototype sites.

We also concluded that the risk of imperfect boreholes would be significantly increased if we attempted to complete a larger hole with conventional 
"oil field" drilling techniques. If we adopted "big hole" drilling techniques we could increase the size without increasing the risk, but we were faced with a sizable jump in cost.

Even the 15-inch cased hole is not a "sure thing". Caprock drilling is unpredictable, and it is sometimes necessary to set an additional string of casing to complete a hole. Thus it is possible that a planned 15-inch completion would have to be reduced to $121 / 2$ inches. That in turn would force a reduction in the planned cavern size to five million barrels since the flow capacity through the hole would be approximately halved. We judged the likelihood of such reductions to be about 20 percent. Thus for a 200 million-barre 1 prototype, we show 16 ten million-barrel caverns and 8 five million-barrel caverns.

After the initial stages of leaching are accomplished, a cavern's potential rate of construction is limited only by the size of the borehole. The more room available to move water in and brine out, the higher the potential leaching rate. If it were desirable to leach very rapidly and there were no limits on the availability of water or the rate of brine disposal, there might be justification for paying the premium required to construct a 19-inch cased borehole rather than a 15-inch hole.

Such a condition may exist at a particular construction site and the final designer may opt for a larger hole. However, in order to use a flexible but standardized design for this prototype study, we concluded that a 15-inch hole represented the most practical choice.

Another standardization we adopted to facilitate the prototype design was to establish a maximum rate of brine discharge of 2,000 gpm for the 15-inch hole and 1,000 gpm for the 12 1/2-inch hole. These rates can be achieved by injecting water and/or oil at reasonable pressures and velocities. They represent points on the power consumption curves where the cost of accelerating flow may exceed the savings from accelerating leaching.

During a period of no $0 i l$ addition, a 2,000 gpm saturated brine production rate resulting from fresh water injection would enlarge a cavern at the 
rate of about 11,700 barrels per day. If 011 were added at a rate equal to the rate of enlargement, a 2,000 gpm saturated brine production rate resulting from fresh water injection would permit oil to be stored at the rate of about 10,000 barrels per day. These figures should be used with caution, however, for they represent theoretical maximums, not average rates. 


\section{LEACHING WELL DESIGN}

Storage wells are drilled with "oil field" type rotary drilling procedures. A rotary bit is connected to surface by pipe. The bit supports the lower portion of the pipe, thereby deriving the downward thrust necessary to penetrate the rock. The lower portion of pipe--a series of drill collars--is very stiff, heavy, and resistant to buckling. The upper pipe--known as drill pipe--is kept in tension and consequently can be much more flexible.

Most drilling is done by rotating the bit with torque transmitted from the surface through the drill pipe and collars. Bits generally consist of three rolling cones, each serrated with short, husky teeth. As each tooth is pressed against the bottom of the hole, a small chip is fractured away from the parent rock.

For drilling to proceed, chips must be transported from the face of the cutters to the surface. This is accomplished by pumping a fluid known as mud down the pipe to the bit where it exits, picking up the cuttings and carrying them to the surface through the borehole annulus. Besides transporting cuttings, the mud also cools the bit and supplies a stabilizing pressure to the borehole walls.

Many sedimentary rocks are so weak that they would cave if mud support were not available. Maintaining the proper composition and quality of mud is a critical factor in any drilling program. The wrong mud can cause hydration of shales, dissolve salt, slow drilling penetration, cause walls to fail and pipe to stick, and numerous other problems.

Regardless of how good the mud is, however, circulation must be maintained if the mud is to do its job. Many rocks are porous, permeable and contain fluids existing at pressures less than that of the borehole mud. Consequently, the mud must be able to seal the walls of the hole or it will flow into the rock rather than back to the surface. Although the drilling industry has developed muds for almost every drilling condition, vugular or cavernous structures occasionally defy sealing and circulation fails. 
If the uncased borehole is composed of competent rocks when circulation is lost, the driller can utilize many materials including cement to seal the loss zone. In some instances, he may be able to proceed with drilling by sacrificing his mud and allowing cuttings to be deposited into the loss zone. If he can tolerate a reduction in hole size, he may choose to place steel casing across the zone.

However, if the uncased borehole consists of weak or unconsolidated sediments, the driller may never get an opportunity to re-establish circulation. The weak walls may begin to cave and bridge the hole. The drilling assembly may become stuck. In some instances, caving has been so severe that the drilling rig has been undermined and toppled.

Obviously, the likelihood of completing a hole is improved if the weak portion of the borehole has been lined with steel casing before circulation is lost. Intermediate strings of casing are of ten needed for other reasons. A short section of casing called "conductor pipe" is usually set by other excavation techniques before the rotary drilling rig is mobilized. This pipe is used to conduct the mud from the hole to the settling tanks or pits, thus preventing the ground under the rig from being washed away.

A somewhat longer string of pipe called "surface casing" is usually set after the hole has been advanced through the potable water zones. This protects the water from mud contamination and from fluids or gases that might be encountered deeper in the hole. Since those fluids or gases may be under high pressure, a blowout prevention device is usually mounted on the top of the surface casing.

For the casing to serve its purpose, it must be sealed into the hole. This is usually accomplished by pumping cement down the casing and up into the annulus. After the proper quantity of cement slurry has been placed in the casing, a separation plug is inserted and pumped down with mud. The plug seals against a shoe installed at the base of the casing, preventing mud from escaping in to the annulus.

The slurry of high strength cement is quite dense, exerting much more pressure on the borehole than the mud it replaces. Consequently, a hole that 
can support a full column of mud to surface may fail under the pressure induced by a similar column of cement. At the instant of such a failure, a rather tall column of cement may exist in the annulus; but as a result of the failure, the cement may fall back downward until the pressure exerted by the remaining column is no greater than the natural fluid pressure within the thieving strata.

The result of attempting to raise cement too high in the annulus may be a shorter cement column than would have been achieved if a more conservative objective had been set. There are procedures that can be used to place a second stage of cement above the first following a failure, but the results are seldom equal in quality to those achieved with a properly placed primary stage.

The leaching well design established for this prototype study is considered relatively conservative. We have gambled with cheaper designs and often succeeded, but we also have had failures. In some instances, what were planned as cheap holes proved quite expensive because insufficient casing had been set to deal with the severity of lost circulation actually encountered. Most of the problems have stemmed from the unpredictability of cap rock. Adjacent holes in the same dome may behave quite differently from one another. One may permit strong circulation throughout drilling and cementing, while the other may prove so troublesome that an extra casing string must be set to achieve completion.

Because we know very little about the cap rock at many of the prototype sites, our standard design must be conducive to successful completion, even under relatively difficult conditions. The design shown in Figure B.2 is described as follows:

Conductor Pipe - Insta 1160 to 100 feet of 42-inch conductor pipe prior to mobilizing the drilling rig. The pipe may be driven into place under swampy conditions, or a bucket rig may be used on dry ground. Under severe conditions, a greater length of pipe may be required.

Surface Casing - Drill sufficient hole to set 30-inch pipe through the potable water zones. This pipe may be connected by field welding, or special 


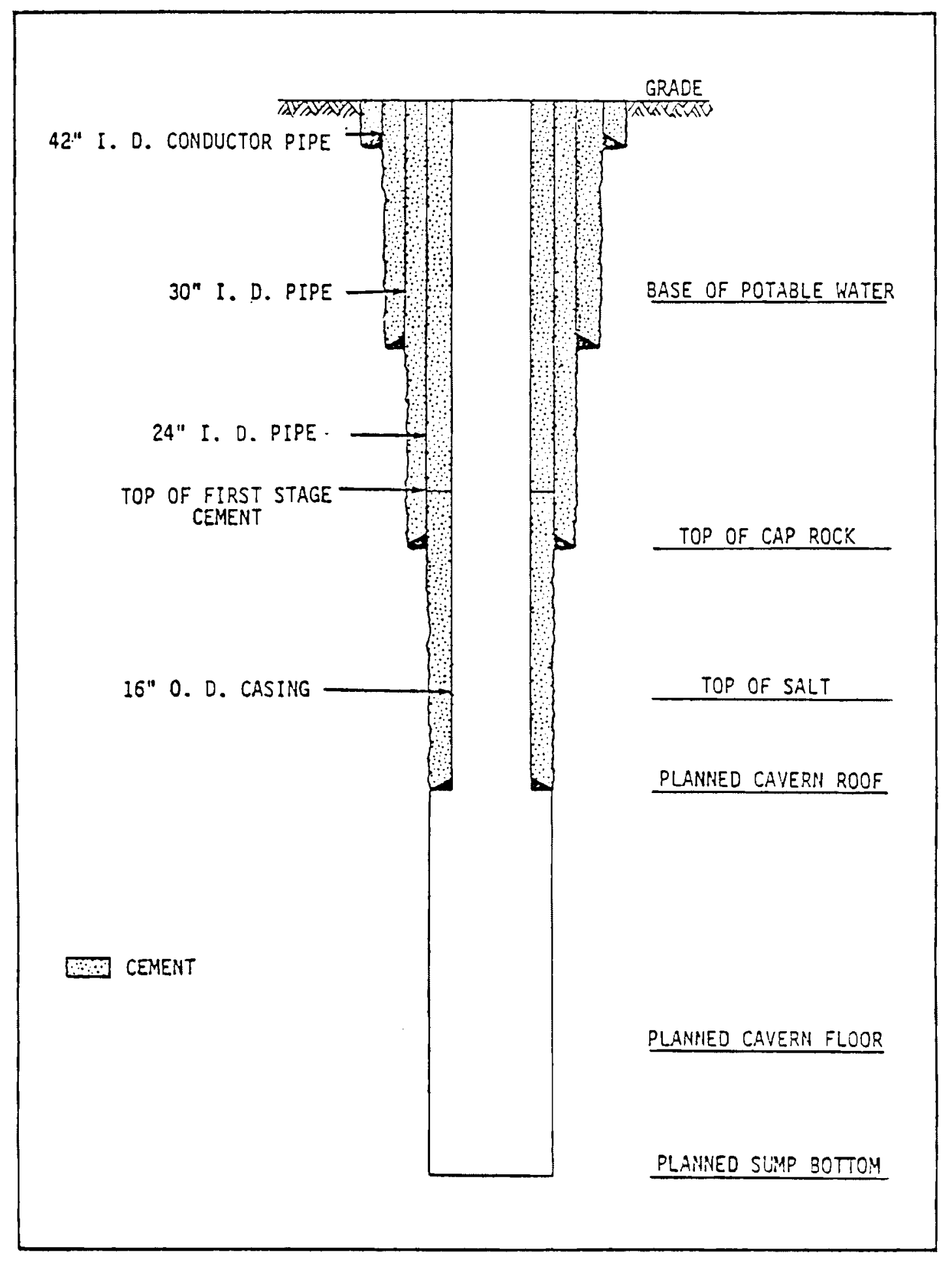

FIGURE B.2. Leaching We11 Design 
connectors may be installed before running. Cementation can be accomplished through drill pipe by stabbing into a specially designed cementing shoe. The pipe should be cemented from bottom to surface and a blowout preventer should be installed.

Intermediate Casing - Drill sufficient hole to set 24-inch pipe to the top of the cap rock and cement annulus from bottom to top. This pipe should be equipped with special connectors prior to running.

Product Casing - Drill sufficient hole to set 16-inch casing to a depth of at least 500 feet into the salt. If good drilling conditions exist, the hole can be advanced to the planned sump bottom before running the casing.

If circulation problems develop while drilling the cap rock, the driller may choose from a number of options. He may try to re-establish good circulation by blending filler materials into the mud, attempt to advance to the projected casing point in the salt by drilling without fluid returns using brine injection, or try to seal the void with cement. If all else fails, he may attempt to set the 16-inch casing through the problem zone, and if successful, proceed to set $133 / 8$-inch casing into the salt.

Regardless of his tactics his drilling fluid, be it mud or brine, must be saturated with salt before penetrating the top of the salt mass. If the salt is drilled with unsaturated fluid the borehole will enlarge, causing problems in maintaining directional control, tool joint failures from buckling of the drill collars, and difficulties in obtaining good cementation of the product casing.

The cementing program should be designed to raise the cement column well into the 24-inch pipe. In most instances, it would be unadvisable to attempt cementation to surface in a primary stage. If full cementation is deemed imperative, a stage collar should be installed as the 16-inch casing is run to permit secondary cement placement after the primary stage has hydrated. If the hole has been completed without mud circulation, special nitrogen procedures may be required to achieve primary cementation into the 24-inch pipe.

The preceding design has several conservative features. The 30 -inch pipe provides a third string of protective casing through the potable water. This 
redundant feature should be reassuring to critics who might attempt to slow the approval process on grounds of possible environmental hazards. It also provides blowout preventer control should a pocket of oil or gas be encountered, and assures contiguous cemented pipe should cement fail to circulate up the entire 24-inch pipe annulus. Should the latter occur, small tubing would be run between the 24- and 30-inch pipe and cement would be brought to surface in a secondary stage. Such secondary cementation might be imperfect, but it would fulfill the requirements of state law and would give rigidity to the 24-inch pipe during subsequent drilling.

The 24-inch pipe provides support for all weak or unconsolidated strata between the base of the 30-inch casing and the top of the cap rock. This will permit the driller to battle lost circulation problems in the cap rock without risk of caving in the upper hole. It also assures primary cementation of contiguous casing. If secondary cementation is required, it would be between 16 and 24 inch strings of pipe rather than between pipe and open hole.

A long segment of 16 -inch casing is positioned below the top of the salt to provide a thick salt roof over the cavern. That roof will yield sufficiently as the cavern is enlarged to develop an arched stress pattern, providing support for the overlying cap rock. The long salt borehole will also permit development of an excellent casing-to-salt seal.

Although theoretically, only a few linear feet of cemented salt bore hole would suffice to seal the access pipe into the cavern, failure of that seal during leaching could cause abandonment of the cavern. Such a failure would allow unsaturated brine to escape from the cavern into the cap rock, dissolving out a channel in the salt that quickly would become too large to reseal. Failure during the oil storage mode would probably be detected before causing irreparable damage to the cavern, but some of the lost oil might be unrecoverable.

We urge the reader to remember that this is a prototype design, standardized to meet many unknown conditions. There may be reasons to alter the design following exploratory drilling at each site. Even now, we can anticipate many challenges to the design. 
Someone may suggest that the 30 -inch pipe should be run to the cap rock and the 24-inch pipe be run only if required to combat lost circulation. This may be a satisfactory procedure where the cap rock is shallow and/or there is no risk of encountering hydrocarbons. Another option under these circums tances would be to delete the 30 -inch pipe. If an additional string of casing is required, the final hole would be reduced to 13 3/8-inch casing.

Another possible suggestion would be to substitute 30-inch casing for the 16-inch casing. This would require underreaming of the borehole below the 24-inch pipe to provide sufficient clearance to safely run 20 inch. Such a plan is quite feasible if no circulation problems occur in the cap rock. However, it can become very expensive if lost circulation must be controlled by cementation in the pilot hole, only to be reopened during underreaming. In most instances, we suspect that operational savings achieved with 20 -inch casing would be more than offset by the increased cost of the hole.

Obviously, these and other alternatives have sufficient merit to be worthy of consideration. Hopefully, our prototype design demonstrates sufficient conservatism to provide a valid basis for cost estimating, plus acceptable safeguards for the environment.

OFFSHORE CONSIDERATIONS

In the preceding discussions of onshore wells we have taken the conservative approach that problems associated with cap rock drilling may ultimately force some caverns to be reduced in size. Because of limited geological information and the lack of regulatory precedent, we feel compelled to apply this same conservatism to the design of the two offshore sites, Eugene Island and San Luis Pass.

Our geological information on both domes is very limited. We know virtually nothing about the cap rock, or even if it exists in the case of Eugene Island. We are also handicapped by the fact that no offshore storage caverns have been constructed and, consequently, regulations have not been established.

Our rather scant geological information on Eugene Island seems to indicate almost complete absence of cap rock over the peak of the dome, which lies very 
close to the sea floor (mud line). Because of this, we might be able to set a string of pipe (conductor pipe) directly into the salt and cement a single string of casing to the cavern roof.

Even if rather deep salt is covered with cap rock, there are no potable water zones to protect. So it might be possible to entirely eliminate the surface casing shown in the onshore design and simply set conductor pipes as deep as possible. Then we could run 24-inch pipe to the cavern roof, or complete the hole with 16 -inch casing if cap rock problems required an additional string.

But, in any case, the need to reduce the size of the cavern to five million barrels would be eliminated.

Perhaps the final designer will have access to new geophysical information and be able to obtain approval for a simplified design. At this time, however, we feel a conservative design and estimate is appropriate, thus we have used the same well design offshore that we used onshore. 


\section{CAVERN DESIGN}

The fundamental technique of cavern development is to expose the salt in a drilled hole, inject raw (fresh or low salinity) water into the hole, allow time for the water to dissolve the salt, and displace the resulting brine from the hole. The hole enlarges as the salt dissolves, eventually forming a cavern.

In actual practice, the procedure for cavern development is somewhat more complex as described in the following paragraphs. A typical well configuration for construction of commercial caverns is shown in Figure B.3.

Raw water injected into a cavern makes contact with salt by circulation and diffusion. Circulation is the dominant factor, being caused by both density and pressure differentials. Being lighter than brine, injected raw water tends to rise, causing a "rolling" effect throughout the cavern. This agitation is responsible for the major portion of the dissolution. During the initial leaching effort, the pressure differential between points of fluid entry and exit establishes the direction of fluid movement across the salt face. As the cavern grows, the rolling effect may cause fluid at the salt face to move in the opposite direction.

Two basic washing methods--direct circulation and reverse circulation-are normally used. Direct circulation is more common, involving injection of raw water near the bottom of the cavern and withdrawal of brine through the casing annulus near the top of the cavern. In reverse circulation, water is injected down the casing annulus and enters near the top of the cavern, dis-

placing brine into the tubing at the bottom of the cavern. Both methods employ the same drilling and casing procedures.

When direct circulation methods are used, the maximum diameter occurs near the bottom of the cavern interval and the minimum diameter forms near the top. The reverse circulation method causes development of a large diameter cavern roof, with the diameter decreasing toward the bottom of the cavern, resulting in the so-called "morning glory" type cavern. 


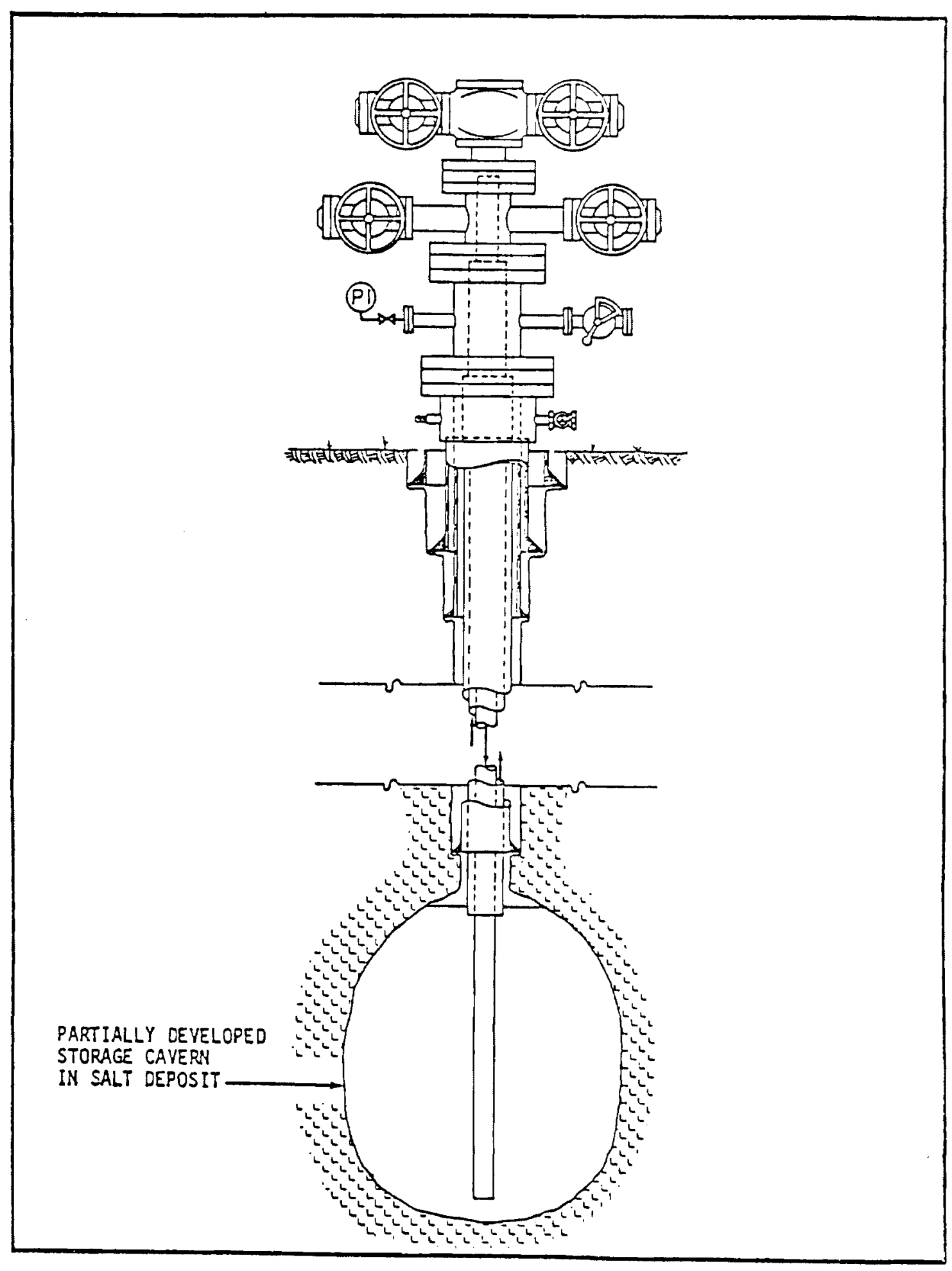

FIGURE B.3. Typical Well Configuration 
To construct large caverns for most storage purposes, we employ modified techniques using direct circulation initially, reverse circulation during primary leaching, and blanket material for control of upward growth.

Blanket material is any noncorrosive lighter than water substance (gas, propane, butane, diesel oil, crude oil) which occupies the space in the topmost interval of the cavern. The purpose of blanket material is to prohibit leaching of salt from around the cemented casing. It also protects the casing from internal corrosion and can be used to initially depress leaching to the bottom of the borehole for construction of a sump.

The protective blanket is extremely important, requiring careful monitoring and maintenance. Protection of cemented casing serves the dual purpose of insuring a pressure-tight cavern and prohibiting development of high spots from which stored product could not be retrieved.

Some insoluble material is present in most salt. As leaching proceeds, an accumulation of insoluble material builds up in the bottom of the cavern, sometimes plugging the wash pipe. This condition can be rectified if a small cavern is first leached below the storage interval. The pipe is then raised to wash the major cavern, allowing solids to accumulate in the sump.

Feedstock (saturated) brine is usually produced by reverse circulation controlled with a retreating blanket procedure. After the lower portion of the hole is leached to the maximum allowable cavern diameter, the blanket level is reestablished higher in the hole and the next interval of salt is leached to the full diameter. This technique requires frequent upward adjustments in the location of tubing, but the cost has not been prohibitive at shallow depths.

Some operators leach storage caverns by direct circulation, with or without blanket control. The resulting low salinity causes high leaching costs, but other economic considerations can sometimes justify the procedure for small facilities.

When the demand for deep natural gas storage caverns became apparent, we adopted a new, modified technique which permits the entire cavern interval 
to be leached without moving the tubing strings. The procedure involves setting blanket at the final cavern roof elevation, and injecting raw water into the lower portion of the cavern. The entire interval is leached simultaneously, yet saturated brine is withdrawn from the bottom of the cavern. This method has proved very efficient and has been adopted for most of the company's leaching projects in thick salt bodies.

The modified leaching procedure also permits the upper portion of the cavern to be used for cyclical storage while leaching continues. Stored product is used as blanket material and the blanket level is lowered or raised as dictated by the storage cycle. During storage periods the lower portion of the cavern enlarges, and when the product is removed the upper portion enlarges. By introducing raw water at the correct depth, balanced cavern growth can be achieved.

A somewhat similar approach could be used in the strategic storage program to permit oil storage concurrent with leaching. To achieve that goal, the procedure shown in Figure $\mathrm{B} .4$ and described below is proposed. This procedure is unique in that it does not require cyclical removal of $0 i 1$ to achieve upper cavern growth.

Conventional oilfield techniques would be used to drill a hole to about 500 feet below the projected cavern floor. Casing is cemented from the surface to the projected cavern roof, at least 500 feet below the top of the salt. Blanket casing is suspended to the projected floor and concentric tubing is suspended to the bottom of the hole. $0 i 1$ is placed in the hole around the blanket casing and raw water injected down the tubing. Brine is withdrawn from the blanket casing, thereby leaching the lower portion of the sump. A few joints of tubing are then removed and the direction of water/brine flow is reversed. Brine of increasing salinity is produced until the sump is of sufficient size to handle anticipated insoluble material.

After completion of the sump, the $0 i 1$ is withdrawn to the elevation of the projected cavern roof and blanket casing is relocated at a point about 170 feet below the oil. Tubing is relocated at the top of the sump. Raw water is injected down the tubing and unsaturated brine is withdrawn from the blanket 


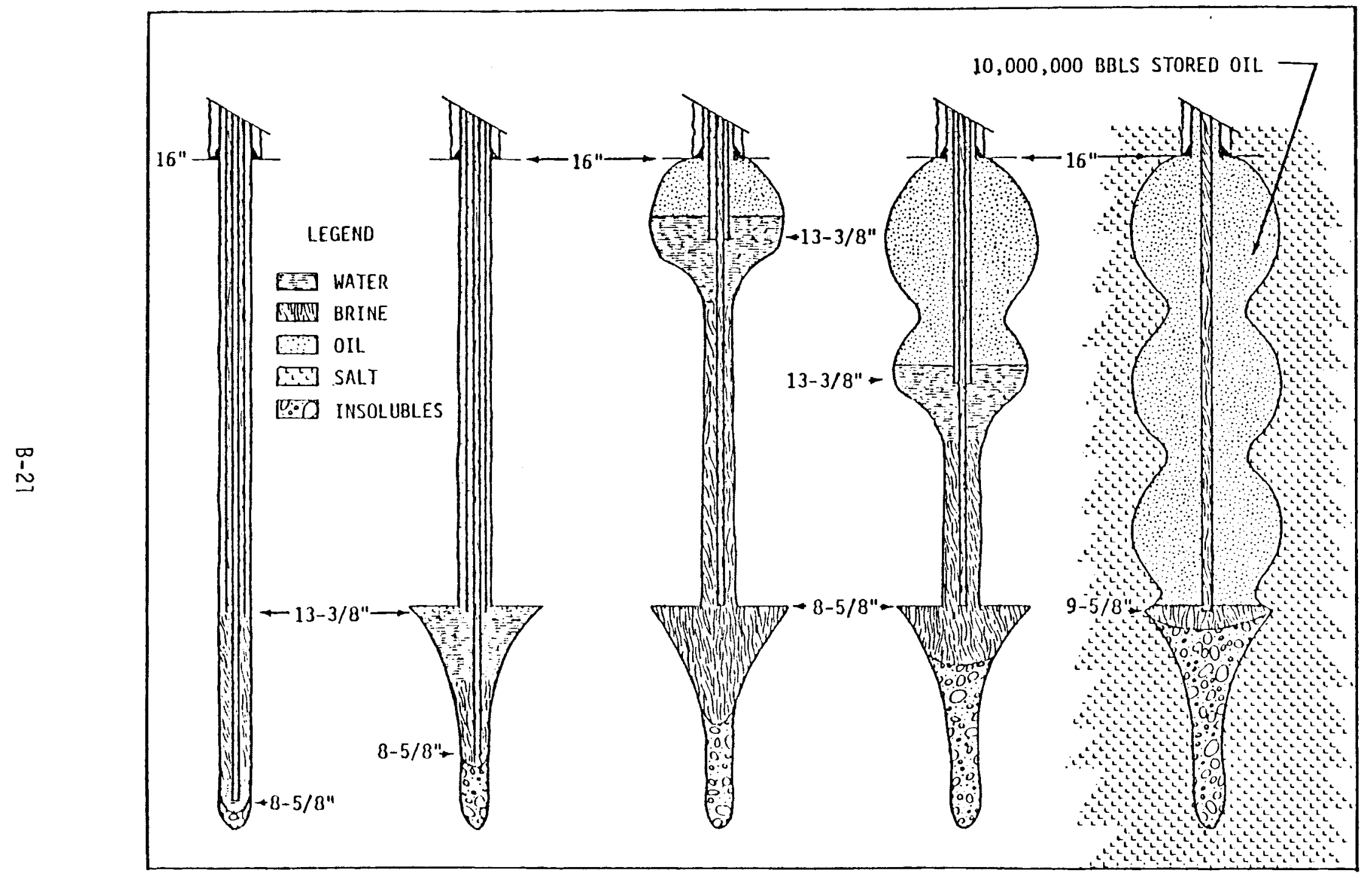

FIGURE B.4. Concept for Commencing Storage While Leaching 
casing until the borehole has been enlarged. Flow direction is then reversed, causing raw water to enter the cavern at the base of the blanket casing and saturated brine to be withdrawn from the tubing. Blanket oil is added as required until the cavern roof reaches a diameter of about 140 feet.

The cavern then would be ready for acceptance of stored crude oil at a rate equal to the rate of cavern enlargement. We compute a maximum rate of about 10,000 barrels per day but use an average figure of about 8,750 over the entire leaching period to allow for initial low salinities and for down time.

When the oil-water interface approaches the bottom of the blanket casing, the casing is repositioned to a point about 500 feet below the roof of the cavern. When the oil-water interface approaches that point, casing would be repositioned again, this time to a point about 840 feet below the roof. Leaching is continued under that condition until the designed volume of 10 million barrels has been developed. The two suspended pipes are then replaced with a single string of $95 / 8$-inch casing reaching to the top of the sump. The final increment of oil required to bring the total of 10 million barrels is added and the cavern is deemed complete.

The cavern's actual shape would depend on the rate and regularity of oil additions, physical characteristics of the salt, and field decisions regarding leaching procedures. Assuming reasonably steady conditions, we would predict a trilobed cavern with a maximum diameter of about 330 feet. More lobes of smaller diameter could be developed if the suspended pipes were repositioned more frequently.

Many illustrations used in this report depict a four-lobed cavern reflecting earlier assumptions. We now believe that the benefits of a fourth lobe would not justify the increased expense, especially on an offshore installation where rig costs are very high.

The preceding dimensions refer to a standardized design for a 1,000-foot high, 10 million-barrel cavern. If drilling problems force the use of an additional string of casing--causing a reduction in the design capacity to five million barrels--the same basic configuration would be developed but the maximum diameter would be reduced to about 250 feet. 
We were forced to deviate from the standardized configuration at the Allen site because additional study of geologic information suggested that the dome was smaller than anticipated. In order to reduce cavern diameters and thereby diminish spacing between wells, we increased cavern height from 1,000 feet to 1,700 feet. Lobes would be leached from blanket casing positions of about 280, 850, and 1,400 feet below the cavern roof. $0 i 1$ storage would commence when the cavern roof reached about 120 feet in diameter and the maximum anticipated lobe diameter would be about 260 feet.

The preceding descriptions called for raw water to enter the cavern at a point below the oil-brine interface. Thus, gravity stratification of oil over water would not be disturbed and no significant agitation would occur to mix the oil with water. Since we don't know the types of crudes that will be stored or their tendencies to emulsify with brine, we were forced to adopt a standardized design that would minimize the risk of emulsification.

A different procedure using fewer pipe movements and resulting in an almost cylindrical cavern might be possible with specific types of crude oil. If laboratory testing demonstrated that a particular crude did not tend to emulsify, or that an emulsion quickly broke under cavern conditions, it might be practical to allow the raw water to fall through the $0 i 1$. Thus the following procedure could be used to develop the configuration shown in Figure B.5.

The sump would be completed as described in the preceding technique. The oil blanket then is withdrawn to the elevation of the projected cavern roof and blanket casing also is relocated to that point. Tubing is repositioned to the top of the sump. Raw water is injected down the tubing and unsaturated brine is withdrawn from the blanket casing until the borehole has been enlarged. Flow direction is then reversed, causing raw water to enter at the projected roof of the cavern and saturated brine to be withdrawn from the tubing. Blanket oil is added as required until the cavern roof has reached a diameter of about 270 feet.

The cavern then would be ready for acceptance of stored crude oil at a rate equal to the rate of cavern enlargement. If saturated brine were produced 
at the rate of 2,000 gpm and 011 were added at a steady rate of about 10,000 barrels per day, a relatively cylindrical cavern should develop. Water would be moving rapidly enough down the blanket casing to keep oil from rising into that annulus and consequently, water injection pressure would be essentially the same as would be required in the earlier standardized design.

Startup pressure following any stoppage of water injection would be much higher, however, for oil would rise into the annulus during the lull. Following completion of leaching, the two suspended strings of pipe would be replaced with a single string of $95 / 8$-inch casing run to the top of the sump.

Both of the concepts shown in Figures 8 and 9 require reasonably constant rates of oil fill to achieve predictable configurations. However, both concepts can be easily altered to permit continued leaching without oil fill or with a reduced rate of oil fill.

The exact alteration would be tailored to fit the anticipated oil fill rate but the general approach would be to relocate the $133 / 8$-inch casing at a lower point in the cavern. Saturated brine production can be continued by reverse circulation with the point of raw water entry as close as 100 feet above the point of brine withdrawal. If this arrangement were employed early in the development period, the cavern would develop a pear shape initially (stem upward). Eventually the rate of growth in the upper cavern would equal and then exceed that of the lower cavern causing the configuration to change from pear to cylinder to truncated cone. The dimensions of these general shapes would be functions of the leaching rate and the depths of water injection. Thus a reasonably well-shaped cavern could be leached to its designed capacity without storage of oil in excess of normal blanket requirements.

It is anticipated that oil will be delivered to the individual storage sites at average rates roughly equivalent to space development. However, the average may be achieved by periodic high rate deliveries separated by periods of no delivery. Consequently, at least one cavern at each site should be developed in a surge vessel configuration. 


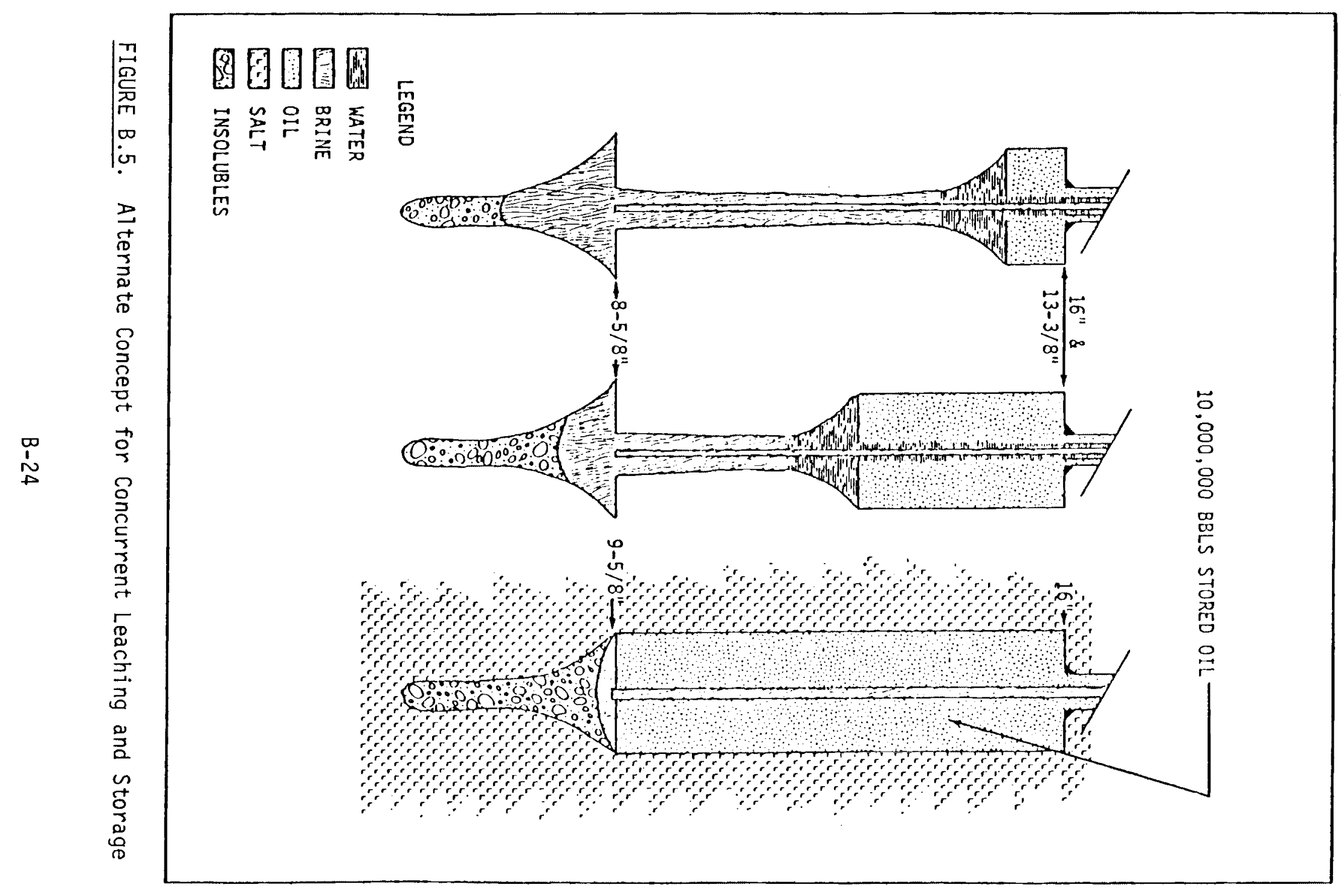


During the early stages of site development, surge would be handled by a pear-shaped cavern where the $133 / 8$-inch casing would be positioned very low in the leaching interval. The surge oil would constitute a blanket of varying thickness with the oil-brine interface shifting between the cavern roof and the base of the $133 / 8$-inch casing.

As site development continues, the standard caverns will gain full diameter near the roof and the surge cavern will approach full diameter in the lower portion of its leaching interval. At this point, one of the standard caverns should be converted to surge use by lowering its $133 / 8$-inch casing. Casing would be raised in the original surge cavern to permit rapid development of its upper regions and conversion to normal storage use. 


\section{LEACHING WATER}

Solution mined storage caverns are created by controlled dissolution of in situ salt deposits. A prerequisite to such construction is a reliable and adequate source of raw (low salinity or fresh) water. Such water is available in abundance in the Gulf Coastal region and many commercial leaching projects have been conducted without any apparent effect on the local hydrologic environment. Unlike commercial projects, however, the strategic storage cavern program will consume such large volumes of water that careful consideration must be given to the alternatives of source.

Under the best of conditions, about six gallons of fresh or moderately saline $(3,000-10,000 \mathrm{mg} / \mathrm{L}$ dissolved solids) water will be required to develop one gallon of storage space. Using sea water, the best case ratio would be nearly 7:1. Thus, a 200 million-barrel onshore facility leached with local water in a 42-month period would consume from 40 to 47 million gallons of water per day, depending on leaching efficiency and the rate of oil addition. A similar facility supplied with sea water would require from 46 to 57 million gallons of water per day.

High rates would also be required during periods of oil withdrawal from storage. To recover 200 million barrels of $0 i 1$ in 150 days would require a fresh water supply of about 58 million gallons per day, or sea water at the rate of about 57 million gallons per day.

All of the onshore prototype designs presented in this study are predicated on use of fresh or low salinity surface water. In every case, enough water is available that withdrawal requirements represent a relatively small impact on the hydrologic environment. In some cases, what seemed to be abundant immediate sources were by-passed in favor of even larger, but more distant supplies. A case in point is the Chacahoula site which lies in a swamp surrounded by large bayous. There we show importation of Mississippi River water because environmental experts concluded that withdrawal from the bayous might alter the salinity of water required by downstream communities. 
Although we made an effort to assess the impact of water withdrawals, our selection of sources may not in every instance be supported by environmental studies yet to be conducted. Full scale analysis of downstream effects from water withdrawal involves very specialized investigatory procedures, far beyond the scope of this study.

Fortunately, alternate or supplemental raw water sources are available in every instance. The alternates generally represent higher costs and impose other environmental consequences but could be considered if prototype selections are denied.

It is technically possible to use water wells at all onshore sites. Moderately saline water would be tapped, leaving the valuable potable water undisturbed. In cases where the potable water essentially floats on saline water, the saline-potable interface may move downward and actually increase the supply of available potable ground water. In most cases, however, saline aquifers are overlain by an impermeable barrier that prevents recharge near the point of withdrawal. Consequently, water must flow horizontally through the aquifer for many miles from the point of recharge to the point of withdrawal.

When water is withdrawn from a well, the water pressure within the aquifer cones downward around the well bore. The hydraulic head existing at the fringes of the cone is higher than at its apex, thus providing the pressure differential necessary to move water through the sand toward the well. If the well is pumped at a steady rate and conditions of aquifer recharge are relatively constant, the areal extent of the cone will increase until the circumscribed area is large enough to supply water at the rate of withdrawal.

During this process of equalization the water pressure in the well will drop; but if the aquifer is sufficiently thick and the rate of withdrawal is not excessive, a steady and reliable flow of water can be produced. If the well is pumped to its full capacity, the water level will continue to drop until the water within the well bore is inadequate to meet pump suction requirements and the rate of flow will level off. (Most pumps are damaged by this condition, so a smaller pump would normally be installed.) 
Many water wells are required to provide the tremendous quantities of water needed to leach and operate the larger prototype facilities. These wells must be spaced far apart to minimize the overlapping of drawdown presure cones. In some instances, multiple aquifers are available so that adjacent wells can withdraw from different zones and interference is avoided. Nevertheless, the well field must be spread over a sufficiently wide area that the rate of withdrawal does not significantly exceed the rate of recharge.

If sands are essentially evacuated by excessive withdrawal, there is risk of permanent aquifer damage plus surface subsidence. Water in a filled aquifer usually exists under sufficient head to support a portion of the overburden load. Removal of that water can cause the sand grains to pack together more tightly, reducing the porosity and permeability within the sand, and causing the overburden to settle.

Many of the prototype sites are surrounded by aquifers having calculated single well capacities of from 5,000 to $8,000 \mathrm{gpm}$. However, we would hesitate to base a well field design of $40,000 \mathrm{gpm}$ for 42 months of withdrawal on such high rates. Well spacing would have to be so great that the surface gathering system cost would offset the savings achieved by limiting the number of wells. We would be more inclined to settle for forty 1,000 gpm wells on spacings which would create minimum interference.

Another option available in every case is importation of water from the Gulf of Mexico. In fact, some of our surface sources may represent such importation. Where we have selected an intercoastal canal located near the Gulf, a sea water influx might develop during periods of low fresh water runoff. However, this option generally refers to pipeline transportation of sea water to an inland leaching site.

The basic problems involved with pipeline construction are 1) the expense, and 2) the environmental impact of extensive dredging. In addition, sea water dissolves less salt per unit volume than do the fresher forms of raw water, thus reducing leaching efficiency and increasing the total volume of brine for disposal. 
$\bullet$ 


\section{BRINE DISPOSAL}

Brine production began to affect the environment long before the recorded presence of man. Even today, most of the salt entering the sea stems from natural leaching by rivers and streams passing through exposed beds of salt or salt bearing rocks. This is a slow process, permitting living organisms to evolve and adjust to changing conditions of salinity. It is the accelerated leaching caused by man that attracts attention in this era of environmental concern.

One of the significant causes of increasing salinity in our surface waters today is irrigation. Tremendous quantities of salt are leached from the soil each year as water drains from the fields back into the rivers. Evaporation and transpiration also reduce the natural ratio of water to dissolved salt. The lower Colorado River has become so saline that our treaty commitments to Mexico are in jeopardy. However, this has also been a gradual process and man has been slow to awaken to its ramifications.

Far more obvious were the side effects of early oil production. Early producers had no facilities for handling water that rose to the surface with their oi1. They simply released it upon the land, into the stream and down the rivers. When they could direct it into flowing water, dilution was usualiy adequate and no apparent damage was observed. When it lay on the land, however, the effect was devastating. Forests died, land became barren, erosion developed and many oil fields became national eyesores.

Laws were passed and safe brine disposal became mandatory. The cost of proper brine disposal became a major factor in the cost of $0 i 1$ production and many oil fields were abandoned because revenue was inadequate to fund brine disposal.

Fortunately, the $0 i 1$ industry was able to solve the problems of brine disposal in most instances. Much of the brine now produced is reinjected into oil bearing formations to drive additional $0 i 1$ to production wells. Where this is not possible or practical, it is injected into naturally saline aquifers located far below those bearing potable water. Although the oil industry 
may once have been negligent in its attitude toward brine, its expertise in this field is now unquestioned. Most of the technology used to dispose of brine during cavern leaching is directly rooted in the experience and knowledge developed by the petroleum industry.

Brine well leaching has been practiced for over 100 years to provide feedstock for salt and chemical production. The requirement for dealing with waste brine from cavern leaching began about 25 years ago when industry realized that leached cavern storage space for LPG could be constructed far cheaper than steel tankage.

Most early hydrocarbon storage caverns were constructed at locations distant from established users of brine. Thus, the brine was valueless and was usually dumped into rivers. Because leaching rates were low and river flows were high, dumping was permitted in Gulf Coastal regions until recent years. Environmental effects of dumping were negligible. Marine life in these coastal rivers was tolerant of minor salinity variations, having already adapted to the natural variations caused by tides. Although the practice of river dumping has now been prohibited by law, many operators of early caverns stoutly defend the practice as harmless. They point out that a 1,000 gpm discharge of saturated brine into a river flowing at four million gpm would cause only an 80 part per million rise in salinity. Radian Corporation findings suggest that an increase of less than 500 ppm could not be detected by organisms.*

Nevertheless, existing law prohibits any program of cavern construction dependent on dumping of brine into rivers. A 200 million barrel facility leached and filled with $0 i 1$ in 42 months would require brine disposal at the rate of 32,000 to $40,000 \mathrm{gpm}$, depending on the source of leaching water and leaching efficiency. Such quantities must either be deposited into the Gulf of Mexico or into saline aquifers.

The effect of such injection into the Gulf is difficult to predict. If the brine were released from a pipe lying on the ocean floor several miles

* "Advance Review of Various Engineering Socioeconomic and Environmental Factors Related to Development and Operation of a Strategic Storage System," published by Radian Corporation on 21 February 1975. 
offshore, a thin layer of heavy brine would probably develop over a considerable area of the ocean floor. Overlying water would be relatively undisturbed, assuming that coastal currents are adequate to disperse the salt carried upward by diffusion.

If the brine were released through a riser at a point near the surface of the sea, the density differential between saturated brine and sea water would cause rapid mixing and dispersion of the salt. Thus, the significant salinity increase would be limited to only a few acres of the sea, but the effect would extend throughout the entire depth of water.

A detailed analysis of brine discharge and resultant environmental effects is beyond the scope of this study but probably can be acquired from another source. We understand that LOOP, Inc. financed such a study for eventual submission as part of an environmental impact statement. We were unable to obtain the study but were given assurances that no unsolvable technical problems exist.

If brine disposal to the sea is chosen as a design parameter for cavern construction, the expected problems will be legal rather than technical. Even the most exhaustive mathematical proof showing negligible environmental damage could be challenged in the courts. It is quite conceivable that construction would be stalled for more than a year, even if the challenge were without any technical merit.

There is also the possibility of an embarrassing interagency dispute. We understand that the EPA intends to ban disposal into the Gulf of any water produced with oil. Obviously, the EPA will be subjected to intensive criticism from oil companies if it permits a government program to discharge large quantities of brine into the Gulf while prohibiting relatively small discharges by private industry.

Brine discharge into saline aquifers is a long established practice of the oil industry. Although regulations vary somewhat between states, all $0 i 1$ producing states accept the principle that such disposal can be accomplished without ecological harm. Regulatory requirements generally mandate that the following conditions be met: 
- Water within the recipient aquifer must be sufficiently saline that the aquifer has no plausible use other than as a source of saline water.

- The recipient aquifer must have adequate reservoir characteristics of porosity, permeability, thickness, and areal extent to contain the projected volume of injected fluid.

- The point of injection must be located and designed in a manner that will prevent harmful effects on hydrocarbon production associated with that aquifer.

- The injection well must be completed in a manner that will assure complete isolation of the injected fluid from all aquifers other than the recipient aquifer.

- Injection pressure at the point of entry into the recipient aquifer must be less than the pressure required to fracture the overlying rock strata.

Any discussion of underground brine disposal must hinge on the subject of reservoir analysis. This is a highly developed science peculiar to the oil industry. The same factors that govern oil flow to a well also govern brine flow from a well. A reservoir analysis for disposal of brine around the Chacahoula dome, premised on the prototype requirement of 200 million barrels of storage space, has been developed and is presented as Appendix $A B$ to that site study.

For those unfamiliar with reservoir performance, a few general comments might be useful. The reader first must adjust to considerations of scale. For most surface design considerations, water can be treated as an incompressible fluid. In fact, both water and reservoir rock are slightly compressible and this characteristic is very important in reservoir calculations.

As an illustration, presume that it were possible to construct an inflexible box, 100 feet high and 19 miles long on each side. Further presume that the box were filled with a section of typical Gulf Coastal disposal reservoir 
comprised of sandstone and saline water. If all of the brine produced while leaching and filling a 200 million-barrel storage facility were added to the contents of the box, pressure within the box would be increased about 1,250 psi (pounds per square inch).

This illustration has little relationship to the actual process of brine disposal, but it is interesting to note that most typical Gulf Coastal disposal reservoirs located at depths of more than 5,000 feet could tolerate a 1,250 psi rise in pressure without resultant harm to the environment.

In the Gulf Coastal region, multiple saline aquifers exist, often totaling several thousand feet in thickness. These sands, with porosities exceeding 30 percent, are believed to extend over areas of several hundred thousand square miles. Consequently, all of the brine that would be produced during construction of all strategic storage caverns could be deposited in the aquifers without appreciable increase in aquifer pressure.

Although reservoir capacity is clearly adequate, there are some physical limitations on how brine can be delivered into the reservoir. The hydraulic implications of disposal injection are roughly equivalent to those of pumping into the small end of a large funnel. There is a tremendous pressure drop as brine travels the first few feet away from the well bore. However, the cross section of flow area increases exponentially as the square of the radial distance from the well bore.

Thus, during injection, reservoir pressure at the well bore might be 1,000 psi higher than pressure at a point several hundred feet away from the well bore. Gulf Coastal aquifers are so thick, porous and permeable that the pressure profile will drop rapidly and will be only a few pounds above the normal reservoir pressure at a relatively short distance from the well. Thus, two wells would demonstrate very little interference with each other if separated by 1,000 feet. A symbolic depiction of well interference is shown in Figure B. 6 .

The reservoir analysis for Chacahoula shown in Appendix $A B$ suggests that an individual disposal well could accept brine at 1,865 gpm for the life of the project. This represents a very conservative analysis of that particular 


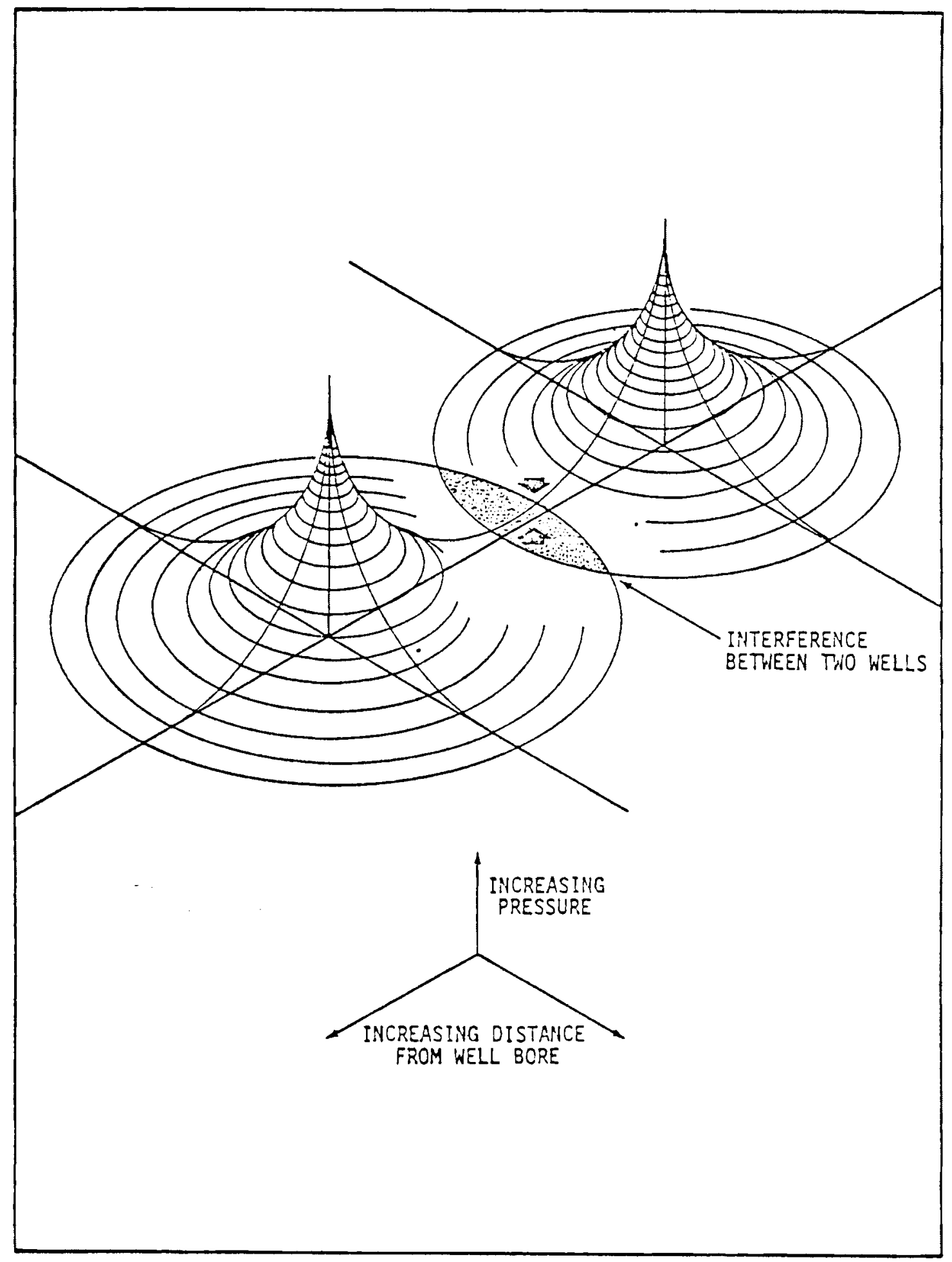

FIGURE B.6. Symbolic Depiction of Pressure Profile Within a Brine Disposal Reservoir 
reservoir so an even greater rate of receptivity might be realistic. There is a considerable difference, however, between theoretical receptivity and actual well performance. The formation adjacent to the well bore may be altered or damaged during the drilling and/or completion work. Formation characteristics will vary between sites and successful completion procedures at one location may prove unsuccessful if applied at another site.

Based on disposal experience around several domes and a knowledge of the geology around prototype sites, we believe that multiple disposal wells averaging 1,000 gpm could be used at every site. Of course, not every well would be successful nor would every well be limited to 1,000 gpm. Some pressure increase would be noted in the aquifer, but the leaching and fill period would be completed before a harmful condition developed. Following the termination of injection, the reservoir pressure would fall off quickly at first and then would asymptotically approach the original reservoir pressure.

We recognize that everyone won't share our optimism. Some critics may suggest that brine will follow a fault or abandoned hole upward and contaminate potable water. We believe that this is unlikely for the following reasons:

The point of disposal injection will be at a depth of 5,000 feet or greater. The potable water zone will probably not exceed 500 feet in depth. Prior to startup of injection, saline water will exist in a 5,000 foot deep disposal reservoir at a pressure of about 2,250 psi. Assuming the worst possible case--that an open pipe ran from 5,000 to 500 feet--the disposal reservoir pressure would have to increase by about $320 \mathrm{psi}$ before it could support a column of saturated brine that would flow into the potable aquifer at 500 feet.

Our calculations indicate that an increase in reservoir pressure of 320 psi is unlikely to occur at a distance greater than 2,000 feet from the point of injection. Thus, a search for abandoned wells could be limited to that distance. Abandoned wells should be relatively easy to locate since few wells exceeding 5,000 feet in depth were drilled prior to adoption of state reporting requirements. 
Some brine may pass out of the disposal reservoir through faults, but the result would be relatively harmless. Thousands of feet of highly porous and permeable sand lie between 5,000 feet and 500 feet. If some of the brine should escape upward through a fault zone, it surely would be dispersed far below any depth of concern. 


\section{CAVERN OPERATION AND INVENTORY CONTROL}

Most commercial caverns are leached to their designed capacity prior to being used for product storage, but some exceptions exist. Occasionally, propane or butane is stored seasonally as a variable blanket while leaching continues. It is not uncommon to allow a cavern to grow by displacing the product from storage with fresh water. If water, salt and a means of brine disposal are adequate, such displacement can postpone the construction of an expensive brine pit while producing very cheap additional space.

Most commercial operators make no attempt to determine the volume of product held in storage by measuring the exact shape and capacity of the cavern. Instead, they simply meter the product entering and leaving the cavern in much the same manner that a pipeline company controls inventories within its lines. In both cases, a loss provision of some small percentage is incorporated into the storage or transportation contract. Since few losses actually occur, the operators often gain ownership to small volumes of product that are excluded from delivery requirements by the loss provisions.

Some operators who store very valuable products, such as ethylene used in their own chemical plants, do attempt to measure inventory within a cavern. In these cases, caverns have stabilized at a constant size and shape and saturated brine is used for product displacement. The cavern profile can be "strapped" by plotting the depth of the brine/product interface against the metered volume of the added product.

Some of these operators are now using a small sonar device, located at the bottom of the displacement tubing, to measure the distance to the interface. This device enables the operator to obtain an instant readout of interface depth, allowing calculation of a material balance on his entire plant at any time.

If strategic storage caverns were completely leached and then aged for closure stabilization prior to the introduction of oil, a similar strapping process could be conducted. Whether or not the preparation of a strap chart 
would be worth the trouble is questionable, however, since its accuracy is dependent on the accuracy of meters used to measure the quantity of inserted 011 .

These same meters are used to measure any oil removed, so the tabulated volume of oil remaining in storage is at least as accurate as a computed volume derived from the strap chart. During periods of dormant storage, spot checks of the interface can be made to determine if theft or leakage have occurred, regardless of whether or not a strap chart exists.

Since the strategic caverns are designed for $0 i 1$ displacement with fresh or low salinity water, cavern growth would occur during any period of oil withdrawal and a new strap chart would have to be constructed during each refill period. Thus, no strap chart could be checked by withdrawal and then reused.

In order to speed up the inception of a storage program, prototype designs presented in this report are predicated on a procedure of concurrent leaching and storage. In essence, this is a reversal of standard leaching practice which calls for caverns to be enlarged from the bottom up.

The standard practice has developed because of the natural tendency of a cavern to leach upward. Newly injected leaching water is much lighter than the brine existing in a cavern and consequently, pops to the top of a cavern before it encounters much solid salt. Thus, a cavern tends to enlarge more rapidily where low salinity water engages the upper regions than where saltier brine exists in the lower depths. To further complicate any attempt to leach downward, a layer of anhydritic sand will accumulate on the floor making it very difficult to impinge leaching water against the bottom by advancing the injection tubing downward.

Rather than fight gravity, leaching operators long ago learned to start as low as they ever intended to go and let the cavern enlarge upward. Some operators start so low that, by the time the unrestrained cavern roof has reached the designed height, the cavern has reached the designed volume and leaching can be halted. 
More often, the cavern is started at a higher elevation, but the upward growth of the roof is restrained by floating a hydrocarbon blanket above the aqueous solution. This forces the low salinity fluid to spread out and dissolve the walls rather than the roof, causing horizontal growth. When the desired diameter is reached, the blanket is allowed to retreat uphole, causing the cavern to renew its upward growth. This can be done by simply thinning the blanket so that irregular parts of the roof become exposed, or by re-establishing the blanket at a higher level and allowing the cavern to grow in an unrestrained fashion to the newly selected blanket level.

Obviously, these normal leaching procedures are not compatible with concurrent storage. Any oil that was added would pop to the top of the cavern, shortening the leaching interval and causing a large pancake type of cavern to develop.

To avoid this situation our design calls for leaching a large sump below the designed cavern interval, enlarging the borehole so that insoluble material can fall freely into the sump, and then commencing leaching at the top of the designed cavern interval. Once a reasonably large roof span has been developed, oil additions can be made at the rate of new space development. The highest rate of leaching will occur immediately below the oil, so the increasing volume of oil will actually fill the newest space in the cavern.

A continual adjustment of stress occurs at the cavern wall as salt is leached away. Before the hole is drilled, the salt exists at reasonably equal triaxial stress which is roughly equivalent to the weight of the overburden. When the hole is drilled and cavern enlargement begins, the triaxial loading of nearby salt becomes unequal because cavern pressure equates to only about half the overburden pressure. Thus, the salt begins to extrude plastically, causing the pattern of unequal stress to extend farther away from the cavern.

The extrusion rate is significant as the wall is being leached away but falls off asymptotically after leaching is halted, and the system of unequal stress can spread far enough away from the wall to reduce differential loading at that point. This process of extrusion is called cavern closure and can become a real problem in a deep natural gas cavern. 
If the gas is withdrawn from the cavern by expansion rather than fluid displacement, cavern pressure can drop so low that a high differential pressure develops between the cavern and the salt. In some extreme instances, closure is believed to have been as high as 30 percent per year.

The planned strategic caverns will suffer little closure after leaching is completed. They will be maintained at an internal pressure equal to a full head of brine which is sufficient, at these relatively shallow depths, to stabilize the closure phenomenon. However, some closure will be occurring as caverns are leached; and because oil will be rapidly filling newly leached space, some closure will occur in the oil filled space.

Early closure would damage the precision of any attempt to strap the cavern during concurrent leaching and storage. Another condition that might occur and damage strapping precision is formation of an emulsion at the brine/ oil contact. Our design calls for raw water to be introduced below the contact in order to minimize agitation that tends to cause emulsification. Nonetheless, a few feet of emulsified brine and oil may develop, masking knowledge of the precise interface elevation that is required for strapping.

We believe that the most precise inventory control can be achieved through investment in a high quality system of redundant meters which would measure oil flow 1) from ship to surge tanks, 2) into the pipeline at the terminal, 3) out of the pipeline at the storage site, and 4) into the caverns. Many of these meters will be manifolded to meter provers so that they can be calibrated routinely and spot checked by auditors. Meters also can be checked by strapping the surge tanks.

The system provides for metered custody transfer to the government at the terminal, electrically linked meters at both ends of the pipeline to detect leakage or theft in transit, and metered flow into caverns to pinpoint the actual volume of oil placed in each vessel. The metering sequence would be reversed during withdrawal of oil from storage, with custody transfer occurring at the point of shiploading or at insertion into arterial pipelines.

Since this procedure is accepted by the oil transportation industry and meets auditing standards, we anticipate no serious objections to its use in 
the strategic program. We are more concerned with questioning on how leakage or theft of oil can be detected in a dormant storage cavern. People may tend to envision masterful thefts of valuable oil by some form of surreptitious entry.

Unfortunately, the general public lacks the technical knowledge to understand just how difficult theft would be or how easily it could be detected. Because people may never completely trust the system, we will probably have to endure novels and movies such as "The Great 011 Heist".

Actually, several simple procedures are available for checking the integrity and quality of dormant storage. These include monitoring of surface pressures, continual sonar monitoring of the brine/oil interface, and density logging to affirm the interface elevation.

When the process of concurrent leaching and storage is completed, the suspended strings of concentric casing are replaced by a single string of displacement casing with its bottom positioned at the top of the sump. The final increment of oil required to complete cavern filling is injected into the annulus, forcing brine up through the displacement casing. If that casing is left open after oil filling is completed a small flow of brine will continue, reflecting cavern closure; but for all intents and purposes, the cavern will have assumed its static storage mode.

The surface pressure of the annular oil will equate to the difference between the head of saturated brine and the head of oil, both measured to the depth of the $0 i 1 /$ brine interface. For example, if the interface were 3,000 feet below the wellhead and $27^{\circ}$ API $0 i 1$ were being stored, the wellhead oil pressure would be about 400 psi.

We would not leave saturated brine inside of the displacement casing because salt would crystallize and eventually plug off the pipe. To prevent this, sufficient fresh water would be pumped into the casing to force the brine out of the pipe and back into the cavern. The fresh water would remain captured in the pipe, essentially floating on the brine. The volume of fresh water injected would be so slight, when compared to the total cavern volume, that the change in cavern pressure would be unmeasurable. The static surface 
pressure within the displacement casing would be about 265 psi but the surface oil pressure would remain about $400 \mathrm{psi}$. Although both of these pressures may rise somewhat with time as cavern closure continues, the differential pressure of $135 \mathrm{psi}$ should remain constant. If the differential pressure decreased, it would be indicative of oil loss from the cavern. More likely, a slight increase would occur as salt moved by diffusion into the fresh water of the displacement casing. If the latter occurred, more fresh water could be pumped in to check if the differential returned to normal.

By monitoring the pressures as shown above, it is possible to catch any significant abnormality occurring in the cavern. Unfortunately the precision of the technique is limited by the accuracy of pressure measurement. A one psi decrease in the differential pressure would indicate a 7 1/2-foot rise in the interface of a 270-foot diameter cavern. This would equate to the loss of over 76,000 barrels, representing only about 0.8 percent of the cavern volume, but perhaps a million dollars worth of oil!

A much more precise technique for constant monitoring would be installation of a sonic interface detector. This device is lowered through the displacement casing on a conducting cable. It has a clever latch and spring mechanism that allows it to catch the bottom of the casing where it swings outside for a view of the interface. It can be kept in this position indefinitely and will deliver, on command from surface, a sonic echo measurement of the distance between the bottom of the casing and the interface.

The manufacturer claims that the device has an accuracy of 0.1 percent of the distance to the interface or one foot, whichever is greater. Since the interface would normally be kept within 10 feet of the casing bottom, this device should detect variations in a clean interface as small as 0.01 feet. The device can be recovered at any time to permit checking of the interface by other means, or simply for replacement with another similar device.

The standard interface checking technique is to run a nuclear logging device through the $95 / 8$-inch casing. This device can determine density of 
material outside the casing and thus detect the interface between two materials of dissimilar densities. The device also has a magnetic collar locator which permits referencing of the interface to the nearest casing collar, a distance that would not exceed 20 feet. This system is capable of discerning variations in a clean interface of less than an inch. It is also useful for determining the thickness of a dirty interface, i.e., a third phase composed of emulsion and/or sediment.

A sample of the oil can be drawn from the wellhead at any time. This is an easy procedure but, unfortunately, the sample would only represent the top of a very long column of oil. If it is deemed essential to sample oil quality at varying levels within the cavern, a means must be devised to get a sampling device through the 011 annulus ( $16 \times 95 / 8$-inch in 10 million-barrel caverns and $133 / 8 \times 85 / 8$ inch in 5 million-barrel caverns).

In some instances, it may be possible to lower a thief device through the annulus on wire line to the desired sampling depth, trigger its sampling mechanism, and retrieve the sample. The hole must be quite straight and the thief must be tapered on both ends to facilitate passage by the displacement casing collars. Wire line operators generally oppose this type of operation in smaller "oil field" type holes because the cable tends to spiral around the casing and resist pulling. We think that the likelihood of success would be improved in the relatively large diameter and short holes used in this program, but field testing would be required.

If the above procedure is impractical, a string of two-inch tubing can be run through the annulus to serve as a conduit for the thief and wireline. This tubing would restrict the well's flow rate capability; but most emergencies would be signaled at least 30 days prior to withdrawal of oil, so time should be available to remove the tubing.

Both of these procedures require special wellheads and the latter requires procurement of a string of tubing. We don't feel that this downhole sampling capability is needed in every cavern and, consequently, we don't show it in our prototype designs. 


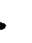




\section{SAFETY CONSIDERATIONS}

For years, industrial designers have concerned themselves with safety of life and property. While these concerns may have been measured more in terms of financial liability than in social obligation, the results have been the same. The public is now expressing increasing demands for safety through jury decisions and support of new legislation, causing the cost of product failures to mount rapidly.

As a result some improvement in safety and reliability is being seen in new products, but often at significant cost to the average consumer. It is easy and relatively inexpensive to make a poor product "a little bit better", but it is usually very difficult and very expensive to improve a near perfect product.

Whether the public will continue to demand perfection when the true cost of that demand begins to sink in, is a matter for conjecture. But as it stands now, the demand does exist and we must respond to it.

The current demand for environmental safety is equally insensitive to cost. Some designs now incorporate such elaborate environmental and ecological safeguards that a cost-benefit analysis would show individual ducks valued at hundreds of thousands of dollars.

Prototype designs presented in this report are believed to meet the legal requirements for environmental protection. In fact, we intend for the designs to exceed the bare minimum considerations of environmental safety, wi th the hope that legal delaying tactics used so effectively against major construction projects of recent years can be avoided.

Fortunately, the inherent characteristics of solution mined caverns make them the safest of all possible means for crude oil storage. A cavern, properly constructed at a dry land location, is extremely resistant to the disaster forces of nature and man. A cavern can stand shock forces far in excess of any earthquakes known to have occurred in the Gulf Coastal area. If oil were forced into a closed cavern at sufficient pressure to cause a fracture to develop, the fracture would close and the cavern would regain its integrity following reduction of the pressure. 
If the entire wel1head were sheared off by bombing or accident, no more than 100 barrels of 011 would escape. (a) This smal1 loss would occur as the downhole pressure exerted by the brine column equalized with the pressure of the oil column. If wellhead damage were severe enough to cause the brine pipe to drop, essentially no oil would be lost. Because no oxygen exists downhole, a fire would snuff out after surface spillage had been consumed.

Offshore cavern facilities seem more vulnerable to sabotage and hurricane damage, but the risks are no greater than those currently accepted for offshore oil production.

An offshore cavern does not have the inherent safety of a dry land facility. If a wellhead or riser pipe were sheared off at the sea floor and special safety devices failed to function properly, oil could flow from the well until the cavern were empty or until remedial action were taken.

If the accident caused the brine pipe to drop downhole, a percolation type flow would probably occur. $0 i 1$ would flow up the pipe until the flow rate grew slow enough to allow sea water to enter and flow downward. The inflow of water might stop the outflow temporarily until the cavern regained pressure from the added water. 0il then would begin to flow upward again, temporarily halting the inflow of water. In this manner, all of the oil could eventually percolate out of the cavern.

If the brine pipe did not fall but were supported by a bent and ruptured riser pipe, sea water might find easy access to the cavern through the brine pipe. This would cause rapid and continuous flow of oil from the cavern.

No safety devices available on today's market can solve this problem, but several mechanisms are sold for use in smaller holes to deal with somewhat similar situations. We contacted one of the suppliers of these devices and were assured that scaled-up versions of their basic designs could be adapted to provide a workable safety device. This adaptation is described in Appendix EB of the Eugene Island Site Study.

(a) See letter from A.H. Medley to Mark Steiner, Federal Energy Administration concerning an error reported here. That letter is reproduced as Figure B.7. 
October 29,1976

\author{
Mr. Mark Steiner \\ Federal Energy Administration \\ Room 532 \\ 1726 M Street, N.W. \\ Washington, D.C. 20461
}

Re: FEA Contract No. C0-05-50306-00

Dear Mr. Steiner:

We have uncovered an error in our earlier work under this contract that should be brought to your attention. Please refer to our final report, volume I entitled "Project I, Investigation of New Leached Caverns in Salt Domes" dated May, 1976.

In the last paragraph on page 63 we say "If the entire wellhead were sheared off by bombing or accident, no more than 100 barrels of oil would escape."

This condition of safety can be achieved, but not under the parameters described on page 64 or earlier on page 60 . The parameters we described called for the oil to be stored at a pressure equal to the differential head between a column of oil and a column of brine reaching to surface. The 100 barrels of spillage we predicted was erroneously predicated on inelastic conditions and represented the volume within the brine pipe that would be evacuated in reducing the differential pressure to zero.

To achieve a condition where dormant storage would withstand catastrophic wellhead damage without significant spillage, such storage should be maintained at a pressure no greater than the head of oil reaching to surface. Thus following completion of cavern filling, oil should be bled from the cavern until the wellhead oil pressure is reduced to zero and the evacuated brine pipe should be filled with oil.

We don't know how this subject was handled in your EIS reports but if our earlier statement was incorporated and is left uncorrected, it could lead to questions regarding environmental safety.

Yours truly,

A.H. Medley

Projects Director

AHM: ns

FIGURE B.7. Letter from A. H. Medley to Mark Steiner 
One hazardous condition that can occur during leaching and/or oil filling is to have oil return to the surface instead of brine. This rarely happens, but the condition can be caused by one of two possibilities. The operator can simply err and overfill the cavern, allowing the oil/brine interface to reach the bottom of the brine return pipe. Or, the brine return pipe can break off at a point above the interface. Long suspended pipes are subject to vibration and fatigue, resulting in occasional failure.

Whatever the cause, a change from brine to $0 i 1$ in the return flow will cause a gradual but significant change in pumping pressures, signaling an abnormal condition. Even if all safety devices failed, the operator would recognize the problem before a large volume of oil were lost. However, in terms of environmental safety, a small volume of oil can do major damage.

To protect against this eventuality, we have incorporated into the design an automatic shutdown system triggered by an induction probe and/or densometer. These redundant sensing devices would detect the presence of $0 i 1$ and signal closure to a motor valve. The slight amount of oil that would pass to disposal prior to valve actuation would be caught in the brine pit at an inland site or in holding vessels at an offshore facility.

In addition to these unique storage safeguards, al1 normal safety features required for similar construction will be incorporated into the design: The brine pit will be of leakproof construction to prevent contamination of ground water by seeping brine; the oil tank will be surrounded by a containment berm; pumps and motors will be protected by multiple sensing devices to detect malfunctions and to activate shutdown systems; and offshore facilities will have fire fighting equipment and personnel safety devices common to offshore oil pumping stations. 
RULES AND REGULATIONS

Solution mined commercial storage caverns have been constructed at onshore locations in both Louisiana and Texas. Much of the technology has been similar to that used in oil and gas production, thus regulatory coverage of the latter has been extended to include the former.

Solution mining for production of brine used in the salt and chemical industries is a much older practice. Most of the older brine fields were established without any regulatory oversight. In recent years, these activities have also fallen under the general jurisdiction of authorities primarily responsible for regulation of $0 i 1$ and gas production.

No procedures have been established for offshore construction of solution mined caverns. We were informed by the U.S. Geological Survey that the only guidelines now available are in Part 253 of "Regulations Pertaining to Mineral Leasing, Operations, and Pipelines on the Outer Continental Shelf" dated August 1975.

The following outlines of Louisiana and Texas rules may not be all inclusive or, in every case, represent the latest ruling. People involved in this aspect of the project are urged to obtain and review the entire documents referenced below.

Louisiana

Reference: Louisiana Salt Domes

Potential for Storage of Crude $0 i 1$

Published by: Department of Conservation Geological $0 i 1$ and Gas Division Dated: May 1975

Requirements to drill product storage wells include:

1. Letter of application, which must include the method of disposing of salt water produced by leaching.

2. Application for work permit (Form MD-11-R). No charge.

3. Plat showing location. 
4. Schematic diagram showing size and depth of casing. (At least two strings cemented to surface for protection of fresh water sands.)

5. Report on Weekly Scout Report during drilling and leaching operations.

6. Final completion report submitted to District Managers, showing date work completed and the approximate size of cavity.

Salt Water Disposal Wells Approval Procedure:

Letter application to the appropriate District Manager to include:

1. An electric log of well if already drilled.

2. Plat of proposed location.

3. An estimated daily volume of salt water to be injected.

4. A statement of other known instances in which the proposed disposal zone has been used for salt water disposal.

5. Insure proper completion to protect water and other possible commercial zones. A schematic diagram of proposed well construction. (If only one cemented string of casing, tubing and packer required.) Surface casing set below fresh and brackish water.

6. An alternative for exceptional deep, fresh, or brackish water sands.

(a) Use a DV tool.

(b) If well abandoned, adequate plugs to protect sands.

$\underline{\text { Texas }}$

Reference: The Railroad Commission of Texas

General Conservation Rules and Regulations of Statewide Application, Supplemented to January 1, 1972 . 


\section{General:}

The requirements to drill product storage wells are:

1. Application for permit to drill. Form $W-1$ (3-1-70).

2. Completion report. Form $\mathrm{W}-2$.

3. Application and permit to store.

4. To establish a new field, a hearing before the Railroad Commission is required.

5. A plat showing well location and offset operators.

Salt water disposal wells approval procedure:

1. Application for permit to drill. Form W-1.

2. Application to dispose of salt water by injection into a porous formation not productive of oil or gas, Form $W-14$, must be made to the Railroad Commission and the Water Quality Board.

3. Sketch of well construction plan including casing program and wellhead.

4. A technical report by a professional engineer describing the geology, prospective disposal sands and the anticipated disposal pressures.

5. A plat showing well location and offset operators.

Specific: (Rules designed for oil or gas operations but applicable to solution mining.)

Rule 1 Organization name must be filed.

Rule 2 Commission has access to property for inspection and/or tests.

Rule 3 Identification of producing properties, wells and tanks thereon.

A. A sign at the principal entrance showing how property is commonly known, name of operator and number of acres in the property.

B. A sign at each well, showing name of property, name of operator and well number. 
E. Signs must be in English language, clearly legible and at least one inch in height.

Rule 5 Application to dri1l, deepen or plug back.

A. Operations shall not be commenced until the permit has been granted and received from the commission and the waiting period has terminated.

C. Application must be on approved form.

Rule 8 Water protected.

A. Fresh water, whether above or below the surface, shall be protected from pollution whether in drilling, plugging, producing or disposing of salt water already produced.

c. 1. b. Impervious collecting pits may be used in conjunction with approved salt water disposal operations, provided authority is received for use of such pits from the Commission.

c. Discharge of mineralized water into a surface drainage water course, whether it be a dry creek, a flowing creek or a river, except where permitted by the commission, is not an acceptable disposal operation and is prohibited.

d. Disposition of mineralized water through offlease facilities such as tank trucks or pipelines, is the initial responsibility of the lease operator and must be permitted by the Commission.

2. Exceptions to the rule can be granted.

4. If a salt water disposal pit is abandoned, it must be back filled and compacted. 


\section{Pollution Prevention}

1. No pollution of waters of offshore and adjacent estuarine zones or damage the aquatic life therein.

2. a. The disposal of liquid waste material into Texas offshore and adjacent estuarine zones shall be limited to salt water and other materials which have been treated, when necessary, for the removal of constituents which may be harmful to aquatic life or injurious to life or property.

b. No oil or other hydrocarbons can be disposed into Texas offshore and adjacent estuarine zones.

c. All deck areas on drilling platforms, barges, workover units and associated equipment both floating and stationary subject to contamination shall be either curbed and connected by drain to a collecting tank, sump or enclosed drilling slot in which the containment will be treated and disposed of without causing hazard or pollution; or else drip pans, or their equivalent, shall be placed under any equipment which might reasonably be considered a source from which pollutants may escape into surrounding water. These drip pans must be piped to collecting tanks, sumps or enclosed drilling slots designed to accommodate a11 reasonably expected drainage. Satisfactory means must be provided to empty the sumps or enclosed drilling slots to prevent overflow or prevent pollution of the surrounding water.

d. Solid combustible waste may be burned and the ashes may be disposed of into Texas offshore and adjacent estuarine zones. 
Solid wastes such as cans, bottles, or any form of trash must be transported to shore in appropriate containers. Edible garbage, which may be consumed by aquatic life without harm, may be disposed of into Texas offshore and adjacent estuarine zones.

e. Drilling muds which contain oil shall be transported to shore or a designated area for disposal. Only oil-free cuttings and fluids from mud systems may be disposed of into Texas offshore and adjacent estuarine zones at or near the surface.

f. Fluids producted from offshore wells shall be mechanically contained in adequately pressurecontrolled piping or vessels from producing well to disposition point. $0 i 1$ and water separation facilities at offshore and onshore locations shall contain safeguards to prevent emission of pollutants to the Texas offshore and adjacent estuarine zones prior to proper treatment.

i. Immediate corrective action shall be taken in all cases where pollution has occurred. An operator responsible for the pollution, shall remove immediately such oil, oil field waste, or other pollution materials from the waters and the shore line where it is found. Such removal operations will be at the expense of the responsible operator.

Rule 11 Inclination and directional surveys required.

II. A. Requirements. Inclination surveys.

1. Form $W-12$.

a. First shot within 500 feet of the surface, then every 500 feet or at the nearest bit change, but not to exceed 1,000 feet apart. 
B. Report Form W-12.

Include sworn statement that well was not intentionally deviated from vertical or that the well was deviated at random, with an explanation of circumstances.

III. A. Requirements. Directional surveys.

1. When total displacement indicated by the inclination surveys computes to be greater than the distance to the nearest lease line or normal spacing distance.

a. Exception can be granted.

2. When well directionally deviated.

a. Must be continuous multishot surveys with shots not more than 200 feet apart.

3. If more than 200 feet of surface pipe, the survey can start there. However, the inclination from the surface to the bottom of the surface pipe must be added cumulatively.

IV. Intentional deviations of wells.

B. When permitted.

1. a. To control another well.

b. Surface conditions unsuitable.

c. Underground conditions unsuitable.

C. Applications for deviations.

V. Surveys on request of other operators.

A. Request must be reviewed and granted by Commission.

Rule 13 Casing

A. 1. Protect fresh water and must be cemented.

2. a. The Commission can grant exceptions to the above on certain listed conditions. 
D. Cement must stand a certain number of hours under pressure before drilling plug.

E. Offshore casing.

1. At least three strings of pipe.

a. Conductor string: not less than 300 feet or more than 800 feet below mud line.

b. Minimum surface casing depths.

To 7,000 feet.........25\% of proposed TD

7,000-10,000 feet......2,000 feet

10,000 feet and below...2,500 feet

2. Blowout preventers.

a. One, remotely controlled, after conductor pipe is set.

b. A minimum of two after surface pipe is set.

3. Kelly cock required on all wells drilled.

4. Mud program.

a. Prevent blowouts.

5. Casing head.

a. Sufficient pressure rating and properly valved.

6. Christmas tree.

a. Sufficient pressure rating and properly valved.

7. "Storm" choke at least 100 feet below the mud line.

Rule 16 Log and completion report.

Within 30 days after completion a report on appropriate form with a log. Form $W-2$ 
Rule 17 Pressure on Bradenhead.

A. A11 wells must be equipped to detect pressure buildup between casing strings and such must be reported at once to Commission.

Rule 20 Notification of fire, breaks, leaks or blowouts.

A. Immediate notice to Commission by telephone or telegraph followed by letter.

B. Any oil losses in excess of five barrels must be reported.

Rule 70 Pipeline permits required. (Form 13 or $X-120$. ) 
.

. 


\section{POWER ALTERNATIVES}

Most of the prototype designs for onshore facilities have been premised on predictions by local utilities that adequate commercial electric power will be available. Nonetheless, we know that most utilities are having great difficulty in preparing for future power demands. They are uncertain about the availability and cost of fuel. Rate increases have lagged behind increases in costs to the dismay of investors. The cost of capital has risen sharply and regulatory action has stagnated the construction of nuclear facilities.

There are several alternatives to commercial power. Basic designs could be changed to use either reciprocating or turbine engine driven pumps, fueled by natural gas or light distillates. The latter could be shipped in or refined on location from the stored crude oil.

Crude oil is seldom used directly as a prime-mover fuel, and then only as a last resort. The crude must be partially refined prior to use, but the degree of refinement depends on the needs of the prime-mover. In general, the lower the temperature of the combustion process, the lower the quality of fuel required. Diesel engines are more tolerant of impurities than turbines.

Combustion temperatures of today's turbines, operating continuously at ful1 load, vary from about $1,700^{\circ} \mathrm{F}$ to about $1,985^{\circ} \mathrm{F}$. A slight increase in combustion temperature results in a substantial improvement in fuel economy, but higher temperatures increase the likelihood of damage by impurities. Although some turbines may run longer between overhauls than others, they are a11 subject to damage by minute amounts of alkali metês.

Solar Division of International Harvester Co. has indicated that vanadium is the most damaging metal, and has established a limit of one-half part per million for their turbines. General Electric, whose turbines operate at a higher temperature with good fuel economy, severely restricts fuel quality. GE specifies not more than five parts per billion of alkali metals including sodium, potassium and vanadium.

In an effort to standardize designs and equipment, a more useful approach might be to develop an alternate source of electric power. The following 
example shown in Tables 4, 5, and 6 is based on the $200 \mathrm{million}$ barrel Chacahoula prototype criteria: General Electric turbines could be delivered, installed and operating within 15 months after firm order. This is considered typical lead time for such equipment. Three turbine/generator units are adequate to supply the 80,000 horsepower required by the Chacahoula prototype. The fourth unit, identical in all respects, has been included as a standby. Thus, any one of the four units may be out of operation for maintenance or repair without disrupting the facility schedule. All costs are in 1976 dollars with no allowance for inflation. 


\section{APPENDIX C \\ THE DEPARTMENT OF ENERGY \\ STRATEGIC PETROLEUM RESERVE}

An Overview of the SPR Project

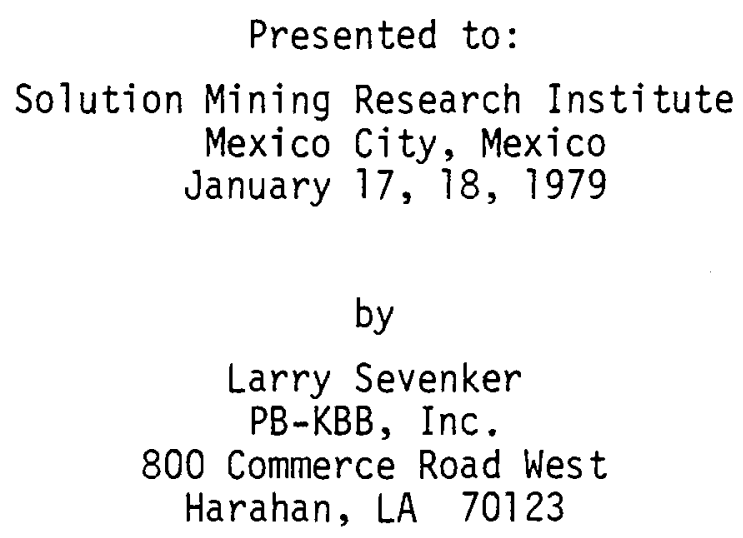

(Reproduced with Permission of PB-KBB, Inc.) 
THE DEPARTMENT OF ENERGY

STRATEGIC PETROLEUM RESERVE

This report represents an engineering design for the Department of Energy prepared by PB-KBB, Inc. Goals, rates and schemes prepared as part of the proposed development for a storage program in the Gulf Coast area were those contracted in PB-KBB's design. This design, goals for storage and development of the various sites does not necessarily represent the actual decision of the Department of Energy to proceed with construction or operation relative to the design.

INTRODUCTION - S.P.R. PROGRAM

In December 1975 the United States Congress passed the Energy Policy and Conservation Act, which established the requirements of a Strategic Petroleum Reserve (S.P.R.) of up to one billion barrels of crude oil. The purpose of the Strategic Petroleum Reserve is to make the United States less vulnerable to severe petroleum supply interruptions such as the one experienced during the oil embargo of the winter of 1973-1974. That embargo by the major oil exporting nations demonstrated the impact that interruption of imports has upon the economy of the United States. Future embargos could have even more severe effects because the United States has increased its dependence upon foreign oil.

The S.P.R. Plan sets the intermediate goals for emergency storage in the Gulf Coast by the end of 1980 and one billion barrels of oil in storage by the end of 1985. The overall responsibility for the Strategic Petroleum Reserve lies with the Department of Energy (DOE), but many other organizations are involved with this project.

BACKGROUND AND GOALS

Implementing the S.P.R. Plan required storage sites located where they would be most accessible to tankers and major pipelines to allow rapid withdrawal and distribution should an interruption of oil supply occur. The most 
desirable locations appeared to be along the Gulf Coast, because that area already receives a majority of the crude oil imported into the United States. Crude oil entering through the Gulf of Mexico is transferred inland via three major pipelines, the Seaway, the Texoma, and the Capline pipelines.

For reasons of economic, environmental, and technical feasibility, as well as those of location and security, solution mined caverns in salt and conventionally mined caverns in salt were determined to be the most acceptable storage sites. Salt dome sites with existing storage capacity were selected to enable development in a relatively short time. Furthermore, these sites are near major crude oil distribution centers. The Bryan Mound dome at Freeport, Texas will serve the Seaway pipeline. West Hackberry and Sulphur Mines near Lake Charles, Louisiana will serve the Texoma pipeline, originating from Nederland, Texas. Bayou Choctaw and Weeks Island in the Baton Rouge, Louisiana area will serve the Capline pipeline at St. James, Louisiana. The combined total existing capacity of these sites is about 250 MMB. The current S.P.R. goals require that existing sites be filled by 1979 .

S.P.R. STORAGE AT EXISTING SITES: 1979

\begin{tabular}{|c|c|}
\hline Site & MMB \\
\hline Bryan Mound & 59 \\
\hline West Hackberry & 51 \\
\hline Sulphur Mines & 22 \\
\hline Bayou Choctaw & 36 \\
\hline Weeks Island & 75 \\
\hline D.0.E. Tanks & 7 \\
\hline TOTAL & \\
\hline
\end{tabular}

The second phase of meeting the S.P.R. requirements will be the possible expansion of sites currently being developed at Bryan Mound, West Hackberry, and Bayou Choctaw. Existing site facilities can be used to develop new storage caverns and will keep costs reasonable as well as allow completion according to schedule in 1985. The combined total proposed exansion capacity of three sites is 320 MMB. 
EXPANSION OF S.P.R. STORAGE AT EXISTING SITES: 1985

\begin{tabular}{ll} 
Site & MMB \\
\hline Bryan Mound & 120 \\
West Hackberry & 160 \\
Bayou Choctaw & $\underline{40}$ \\
TOTAL & 320
\end{tabular}

Other Gulf Coast dome sites are undergoing technical evaluation and environmental analysis. Sites determined to be suitable will further contribute to the objectives of the S.P.R. Plan.

\section{STORAGE SITES AND PIPELINES}

The basic design of the expansion facilities at the storage sites, Bryan Mound, West Hackberry and Bayou Choctaw as accomplished by PB/KBB, under contract to D.O.E.

\section{Bryan Mound/Seaway Pipeline}

At the Bryan Mound salt dome near Freeport, Texas, $0 i 1$ is being stored in four of five existing caverns. Twelve new caverns will be developed, each capable of holding 10 MMB of crude 0il. The Brazos River will provide raw water for leaching.

Brine produced by the leaching operation will be routed through $0 i 1 /$ brine separators and then to holding ponds. From there disposal pumps will pump the brine through a new 26-inch brine disposal pipeline which discharges 12 miles offshore in the Gulf of Mexico. The total pipeline length is 16 miles.

A D.O.E. 30-inch pipeline has been constructed from the berthing facilities at Freeport to Bryan Mound and from there to the Seaway Jones Creek Tank Farm. Four tanks on site will provide surge capacity for the terminal.

Pumping facilities will be operated with the use of high voltage incoming electric power. A substation will be constructed on site, and transformers and switch gear installed to provide the electric power required for the facilities. 
0il withdrawal will utilize the facilities constructed for leaching. The system will be capable of withdrawing 1 MMBPD for a total withdrawal time of 169 days. Raw water injected into the cavern will displace the oil to the surface.

\section{West Hackberry/Texoma Pipeline}

The West Hackberry salt dome near Lake Charles, Louisiana, is used for oil storage in five existing caverns. Sixteen new caverns will be developed each capable of holding 10 million barrels of crude oil. A raw water intake structure located in the Intracoastal Waterway will provide water for leaching. Injection pumps will support leaching operations at a design rate of over 1 MMBPD. Brine disposal pumps will pump brine from the site to 12 miles offshore in the Gulf of Mexico. The total pipeline length is 28 miles. West Hackberry/Texoma Pipeline

The West Hackberry salt dome near Lake Charles, Louisiana, is used for oil storage in five existing caverns. Sixteen new caverns will be developed each capable of holding 10 million barrels of crude oil. A raw water intake structure located in the Intracoastal Waterway will provide water for leaching. Injection pumps will support leaching operations at a design rate of over 1 MMBPD. Brine disposal pumps will pump brine from the site to 12 miles offshore in the Gulf of Mexico. The total pipeline length is 28 miles.

A 42" pipeline from the SUNOCO Terminal, Nederland, Texas will supply oil to the site. Tanks at the terminal will provide surge capacity. The West Hackberry site is currently supported by the Sun Terminal at Hackberry.

The electrical power required to drive pumping facilities will be furnished by transmission lines to the site. A substation will be constructed on site and switchgear installed for power distribution.

West Hackberry is designed for oil withdrawal at 1.4 MMBPD to the Texoma pipeline. The site is designed to be drawn down in 150 days. 011 withdrawn from the Sulphur Mines site will also be distributed by the Texoma pipeline. 


\section{Bayou Choctaw/Capline Pipeline}

$0 i 1$ is being stored in four of fourteen existing caverns at Bayou Choctaw salt dome near Baton Rouge, Louisiana. Four new caverns will be developed, each capable of holding 10 MMB of crude oil. A raw water intake structure located on site at Cavern Lake will provide water for leaching. Brine disposal pumps will pump brine to 11 existing brine disposal wells located near the site. A study of brine disposal at Bayou Choctaw is underway to determine whether additional facilities are required to handle the brine during leaching and $0 i 1$ fill.

All electrical power requirements will be met by expanding the existing substation on adjacent property operated by Allied Chemical. New transformers and switchgear will be installed for power distribution.

The withdrawal rate of 240,000 BPD will draw down the total site capacity within the 150-day criteria originally established by D.0.E.

\section{DESIGN CONCEPT}

To achieve early oil storage and accelerate leaching, the multi-well leaching scheme was developed. The leaching process utilizes three wells per cavern and provided rapid cavern development and early oil fill within the above ground facility restrictions.

New S.P.R. caverns are constructed to a standard design. The only significant difference between caverns is the depth, which is dictated by the geology of the individual site. State regulations also require some modification to the well construction and drilling program.

The basic new S.P.R. cavern is leached to a 2000' high "flower pot" shape having an initial top diameter of $230^{\prime}$ and an initial bottom diameter of $170^{\prime}$. The leach/fill wells are arranged in a triangular pattern in each of the caverns. Precise control will be exercised to hold, with minimum deviation, the $75^{\prime}$ well spacing throughout the cavern height.

For leaching, each well will have a $103 / 4 "$ and $7 "$ casing suspended. After leaching is completed, the two suspended casings will be replaced with 
a single $85 / 8^{\prime \prime}$ casing. The $85 / 8^{\prime \prime}$ suspended casing will be used to inject the displacement water into the bottom of the cavern. This will cause the diameter at the bottom to increase more rapidly during cycling than the top. After 5 cycles, the caverns are planned to be uniform cylinders with a diameter of $270^{\prime}$ and a volume of 20 MMB.

Since this is to be a strategic reserve, it will only be cycled during time of national emergency. Raw water rather than brine will be used to displace the oil, causing the cavern's diameter and volume to increase. Volume will increase approximately 15 percent with each complete cycle.

Cavern Design

The caverns created by the leach-fill process are subject to certain design considerations, the major ones being: stability, hydraulics and leaching.

Stability is a major concern in cavern design. As salt is extracted from the dome by leaching, an arched stress pattern builds up in the salt above the cavern roof. It is therefore necessary to leave sufficient salt above the cavern roof to allow for safe redistribution of the stresses that accompany the creation of the cavern. Cavern roof elevation is thus limited in that minimum thickness must be preserved in the overlying salt bed. Cavern depth is also limited both by economic factors and by the creep behavior of the salt which increases with depth. At great depths, the cavern walls would close at an unacceptable rate. Because of this phenomenon, caverns are not designed for depths greater than 6,000 feet.

In evaluating the relative stability of caverns, two ratios are normally used.

The first is the $S / D$ ratio, which is the ratio of the salt roof thickness $(S)$ to cavern diameter $(D)$. Salt is the most competent rock normally encountered in the Gulf Coast and provides the majority of the structural stability for the caverns. The thicker the salt over the cavern relative to the span of its roof, the stiffer and more stable the roof.

The second ratio used in evaluating cavern stability is the $P / D$ ratio which indicates the amount of salt remaining between the caverns, or the salt 
pillar ( $P$ ) relative to cavern diameter $(D)$. Since the overburden originally supported by the excavated salt must now be supported by the remaining pillar, the average pillar stress increases. The larger the pillars, the lower the pillar stress, and therefore, the decreasing tendency of the pillars to yield. This overburden stress is normally partly balanced by the hydraulic pressure in the cavern.

An average geostatic pressure gradient of $1 \mathrm{psi} / \mathrm{ft}$ of depth is assumed for the Gulf coast domes. If cavern pressure were to exceed this geostatic pressure gradient at any point below the last cemented casing seat, the cavern could be hydrofractured and lose $i$ ts pressure tightness. In order to prevent this occurrence, the maximum operating pressure gradient has been set at $0.80 \mathrm{psi} / \mathrm{ft}$.

When the cavern is filled with oil and brine, the depth of the interface controls the relative surface pressures of the oil and brine. At the oil/ brine interface, the pressures in the oil and brine are equal. When the brine well head pressure is reduced to zero psi, there will still be pressure on the oil side of the wellhead. In order to reduce the oil wellhead pressure to zero psi, approximately one percent of the volume of oil must be bled off. This bleed off volume is based on past D.O.E. experience and is the result of both the compressibility of the fluids and the volumetric closure of the cavern due to reduced internal pressure.

The cavern closure continues at fairly high rates while the cavern is depressurized and a steady outflow of oil must be taken away from the well to maintain approximately zero pressure. If the wellhead is shut in, the pressure will rapidly increase to a range of $50-100$ psi in 24 hours and then continue to rise at a decreasing rate.

Work-overs will occur in caverns containing several millions of barrels of $0 i 1$ and will involve long periods of depressurization.

The caverns will be subjected to several cycles of depressurization, which will reduce the support to the roof. A safety factor is included in the design of the new S.P.R. caverns to ensure that repeated depressurization will not affect structural stability. 
Wel1 Program

The wells used for the leach/fill caverns are designed to provide maximum protection against the possible pollution of surface water during the life of the project, and to guarantee well integrity throughout the life of the well.

Each cavern utilizes three wells which are constructed before leaching begins. The wells are in a triangular arrangement and spaced 75 feet apart. Each cavern is leached simultaneously through all three wells. The casing programs for each site were designed to meet the state regulations and engineering requirements in the most economical manner. The topmost casing is a 26" conductor pipe driven to a depth of approximately 80'. A 20" protection string will be set into the top of the caprock and fully cemented to the surface. This casing will provide protection from fluid migration between aquifers. A 16" casing will be cemented approximately 100' into the salt as a further protective string. Finally, a $133 / 8^{\prime \prime}$ production casing will be cemented approximately $600^{\prime}$ into the salt, with cement returned to the surface.

At some sites, the caprock is known to be poor and an additional string of casing will be required. In order to insure that the well is completed with $133 / 8$ inch casing to the required depth, a larger conductor pipe and surface casing must be set. The topmost casing is a 36 -inch conductor pipe driven to approximately 80 feet. A 26 -inch protection string will be set into the top of the caprock and cemented to the surface.

The program then calls for a 20-inch string of casing to be cemented to approximately 100 feet into the salt. If caving or serious circulation losses occur in the caprock, the 20-inch string can be set tiorough this interval and a 16-inch casing string cemented 100 feet into the salt. Then the $133 / 8$ inch production casing will be cemented approximately 600 feet into the salt.

Thus, the well programs provide for at least two fully cemented strings of casing into the salt. The integrity of each casing will be verified by pressure testing before the cement shoe is drilled out. Logs will be run to verify cement bond after cementing each casing.

Once well pressure tightness is established, two suspended strings, one a $103 / 4$ inch, the other a 7 -inch, will be run for subsequent leaching of the cavern. 
Leaching of the cavern will be carefully controlled to insure that the casing seat is not undermined and thereby prevent any uncontrolled leaching that might possibly lead to loss of pressure tightness.

\section{Leach/Fi11 Program}

Direct leaching (tubing injection) is used to create both the sump and the chimney stages.

Indirect leaching (annular injection) is employed in constructing the roof and in leaching the cavern to its final storage capacity.

0il fill, when performed during leaching, is accomplished by injecting oil through the annulus between the cemented casing and the outer leaching string. When the cavern has been finished, the oil is carried through the annulus between the cemented casing and the $85 / 8$ inch brine production casing which replaces the two leaching strings.

A three-well system is designed for flow rates of approximately 45,000 BPD per we11, or 135,000 BPD per cavern. To maximize the development of solutionmined cavern storage, leaching flow rates and brine disposal rates must be maintained at a maximum. Approximately 7 barrels of raw water are required to leach one barrel of cavern volume. During the early stages, however, the leaching of one barrel of cavern volume requires the injection of larger amounts of raw water because brine concentration is low. The advanced stages will produce cavern volume at the optimum concentration and flow rates.

\section{Leaching}

Cavern design with regard to leaching is based on calculations using a three-dimensional model for solution-mining simulation. The model was developed in 1973 and has since been successfully used on numerous cavern projects. The model is capable of simulating the leaching process and predicting the following criteria from the beginning to the end of the leaching period:

- Cavern Configuration

- Rate of Volume Creation per Day

- Gross Cavern Volume

- Net Cavern Volume 
- Residue Volume

- Depth of Residue Bed

- Volume of Hydrocarbon Blanket

- Bottom of Hydrocarbon Blanket

Input data for the model are:

- Salt Properties

- Salt Components

- Volume Fraction of Insolubles

- Depth of Boreholes

- Location of the Suspended Leaching Strings at Various Time Steps

- Flow Direction - Direct or Indirect

- Blanket Depth or 0il Injection and 0 il Withdrawal Flow Rates

- Raw Water Injection Rate

The exact properties of the salt underlying the sites are not yet known and current analysis is based upon leaching in homogeneous salt. The content of insoluble salt material has been assumed to be five percent of the volume for simulation. The salinity of the injected raw water has been assumed to be between 0 and 36 grams per liter, which corresponds to the salinity of fresh water and sea water, respectively.

Product cycling is important to design because it affects cavern volume and shape. The final shape must therefore be designed so that stability is maintained after cycling. To achieve the desired final cylindrical configuration, the initially leached cavern must be of a "flower pot" shape.

\section{Leach and Fill Procedure}

The leach/fill procedure has been developed to meet the D.0.E. schedule for oil storage. To meet those goals it was necessary to consider in detail the impact that critical items such as work-overs for sonars and re-setting leaching strings would have on the schedule. Cavern leaching and filling was consequently optimized to provide maximum rates of oil storage yet maintain all safeguards to control and monitor leaching. 
The actual schedule for leach/fill of each cavern is therefore somewhat complex and will be dependent on actual oil deliveries.

The leach/fill procedure for cavern construction takes place in five major stages. The stages are: Sump Development, Chimney Leaching, Roof Development and Two Stages of Cavern Leach/Fill Using Indirect Leaching.

Each major stage of development is followed by a cavern depressurization and sonar survey. Careful reviews will be made at those times to determine the actual leached configuration and adjustments made accordingly to develop the caverns as closely as possible to the design. During the development of the cavern, the depth of the $0 i 1 / b r i n e$ interface is frequently measured to monitor cavern growth.

Sump Development

The first step is sump development. A total volume of one million barrels is required to hold the estimated five percent insoluble impurities in the salt which will drop to the bottom during cavern enlargement. This space must be created in advance, and once filled will no longer represent oil storage space.

An $0 i 1 / b r i n e$ interface is established at the planned roof elevation to protect the cavern roof from leaching. Leaching begins using direct circulation.

When the sump stage is completed, leaching will be interrupted and the cavern depressurized. The first of six scheduled cavern sonar surveys will then be performed.

Chimney Leaching

The leaching strings will be repositioned and the $0 i 1 /$ brine interface reestablished at the cavern roof. Step two will then begin with direct leaching used to create the chimney. Chimneys will be complete after reaching a cavern volume of approximately 2.5 MMB. When the chimneys are complete, the caverns will be depressurized and a sonar survey made. 


\section{Roof Development}

In roof development, leaching strings will be repositioned for leaching using indirect circulation. The oil/brine interface will again be established at the cavern roof. Roof development and oil injection will proceed in increments which give optimum control over the shape of the roof. After each incremental volume is created, oil will be injected to lower the $0 i 1 /$ brine contact. 0il injection will not interrupt the leaching process. It is expected that coalescence in the roof region around the three wells will occur during roof construction.

Two sonar surveys are scheduled as a part of roof development. The first provides early control of roof shape as well as detects coalescence with the other wells of this final cavern. The second sonar is conducted at the end of roof development.

Reverse Leach/Fil1

After completion of the fourth sonar survey, the leaching strings will be repositioned. Simultaneously with indirect leaching, oil will be injected to fill the upper part of the cavern. 0il/brine interface levels will be regularly monitored after oil injections. When the cavern has a net volume of about 9.4 MMB, the fifth sonar survey will be conducted.

The final leach/fill stage will be conducted with the leaching strings set near each other. Leach/fill will continue until a net cavern volume of 11 MMB is reached.

Both leaching casings will be removed and the sixth sonar survey is then conducted to verify that the full cavern volume has been reached. The final oil fill is then made to bring the total storage to $10 \mathrm{MMB}$.

For every 10 MMB oil storage cavern, an additional volume of 1 MMB is required to compensate for cavern creep and to provide a margin, or cushion. Thus, in a 10 MMB oil storage facility, the total open cavern space will be 11 MMB. 


\section{Work-Over Procedure}

During well adjustment and cavern surveys special work-over procedures will apply. Safety procedure will be implemented for each workover. Blow out preventers or wireline lubricators will be installed on the wellhead for required well maintenance and surveys. The equipment will vary according to the service or adjustment required. The wellhead will be disassembled and safety equipment installed. The requirements of work-over operation are classified accordingly.

\begin{tabular}{|c|c|}
\hline Operation & Safety Equipment \\
\hline 7" Tubing & Lubricator on Wellhead \\
\hline $103 / 4^{\prime \prime}$ Casing & $\begin{array}{l}\text { Blowout Preventor and Shear } \\
\text { Rams on } 133 / 8^{\prime \prime} \text { Assembly }\end{array}$ \\
\hline $133 / 8 "$ Casing & $\begin{array}{l}\text { Blowout Preventor and Shear } \\
\text { Rams on } 20^{\prime \prime} \text { Assembly }\end{array}$ \\
\hline
\end{tabular}

\section{SUMMARY}

Throughout the design and construction, numerous precautions are taken to assure safe and well controlled cavern development. The locations of both existing and expansion caverns are carefully considered to assure cavern stability. Cavern design takes into account stability for the individual cavern by providing for sufficient salt roof, and also considers in detail well hydraulics and the effects of product cycling.

The cavern leaching program utilizes a sophisticated computer model to simulate and predict the leaching process. These predictions will be used as a sound basis for evaluation of actual leach configurations of the caverns.

The initial well completion has several pressure tests to verify integrity. In particular, the pressure tightness of the initial well to the bottom of the cavern and the final cemented casing will be verified by a pressure test.

At each stage of the leach/fill of a cavern, work-overs will be preceded by a depressurization. Careful review of the sonars and actual configuration 
of the cavern will be used to adjust the subsequent stages of leach/fill if required. In addition, frequent monitoring of flowrates, wellhead pressures, brine composition, and oil/brine interface will verify that the process follows the design.

Verification of cavern development is conducted at several stages of leach/fill. These numerous steps of verification of cavern integrity and cavern development are conducted before beginning additional oil injection. 
CONTRIBUTION OF EXISTING SITES

TO S.P.R. GOALS (MMB)

\begin{tabular}{lr} 
Existing Sites & 1979 \\
\hline Bryan Mound & 59 \\
West Hackberry & 51 \\
Sulphur Mines & 22 \\
Bayou Choctaw & 36 \\
Weeks Island & 75 \\
D.O.E. Tanks & 7 \\
\multicolumn{1}{c}{ TOTAL } & 250
\end{tabular}

C-15 


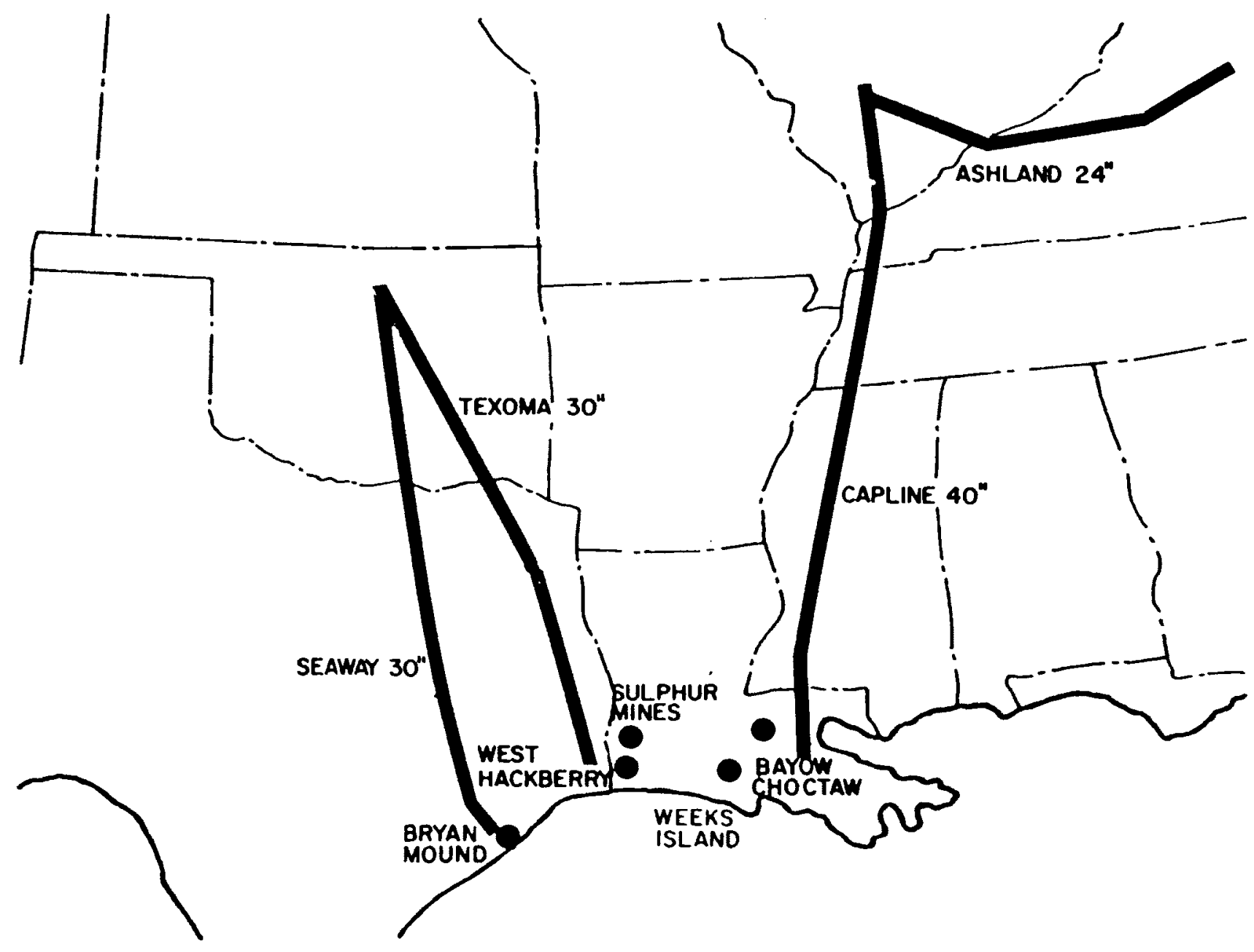

SPR SITES AND THREE MAJOR CRUDE OIL PIPELINES 


\title{
CONTRIBUTION OF EXPANSION
}

OF EXISTING SITES

\author{
TO S.P.R. GOALS (MMB)
}

Expansion of

Existing Sites $\quad \underline{1985}$

Bryan Mound

120

West Hackberry

160

Bayou Choctaw

40

TOTALS

320 MMB 


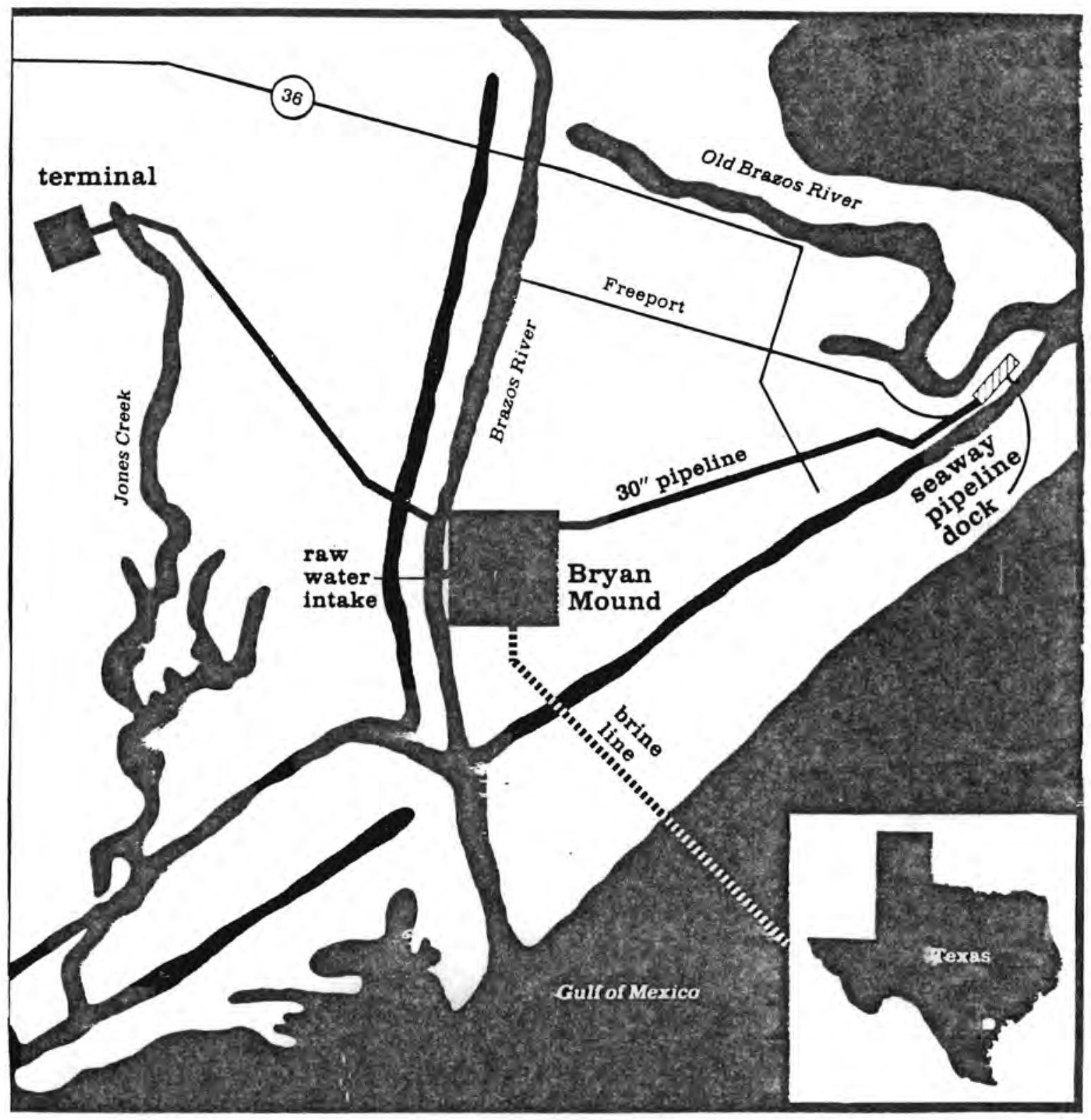

$\frac{\text { PB }}{\text { KBB }}$ 


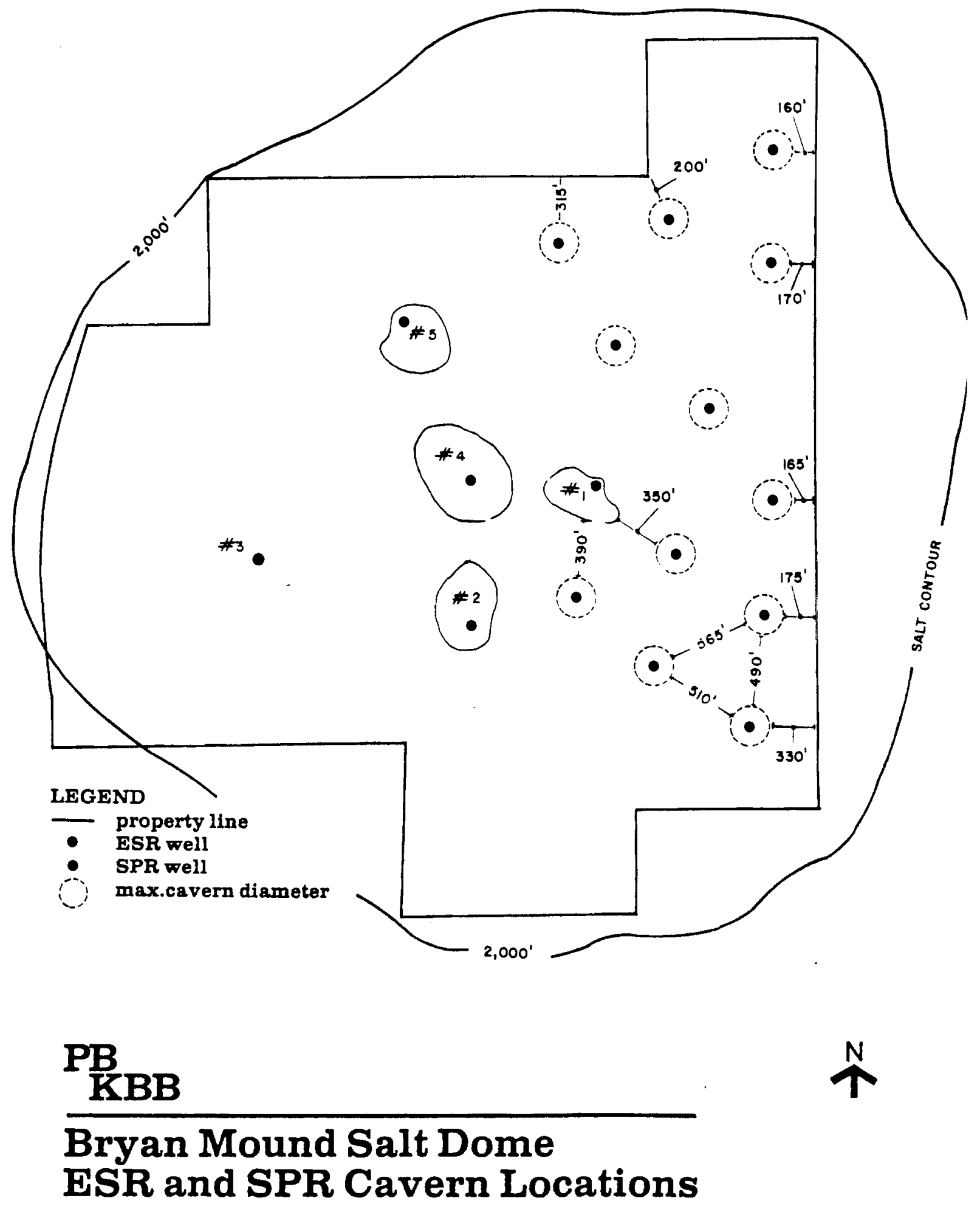




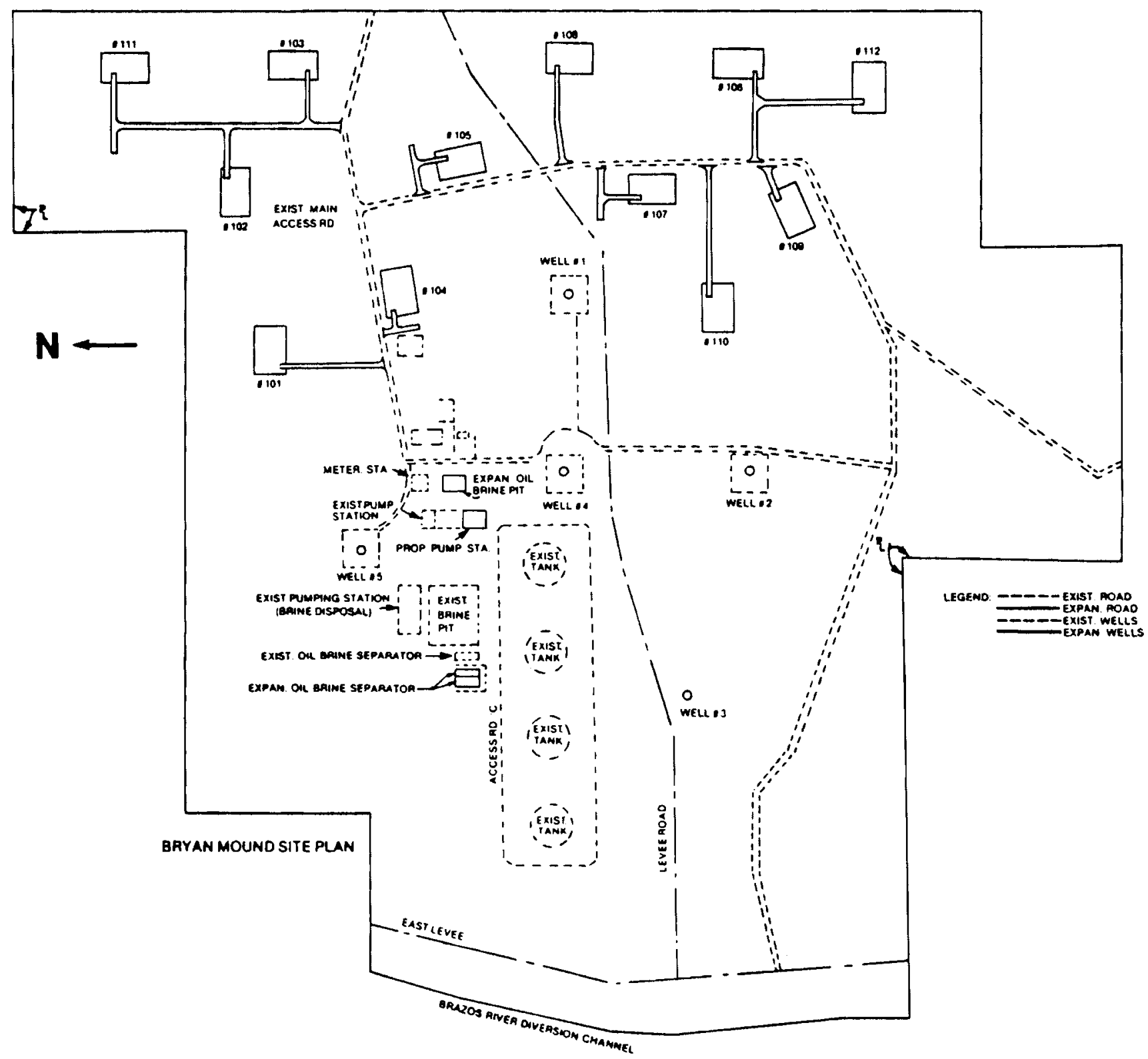




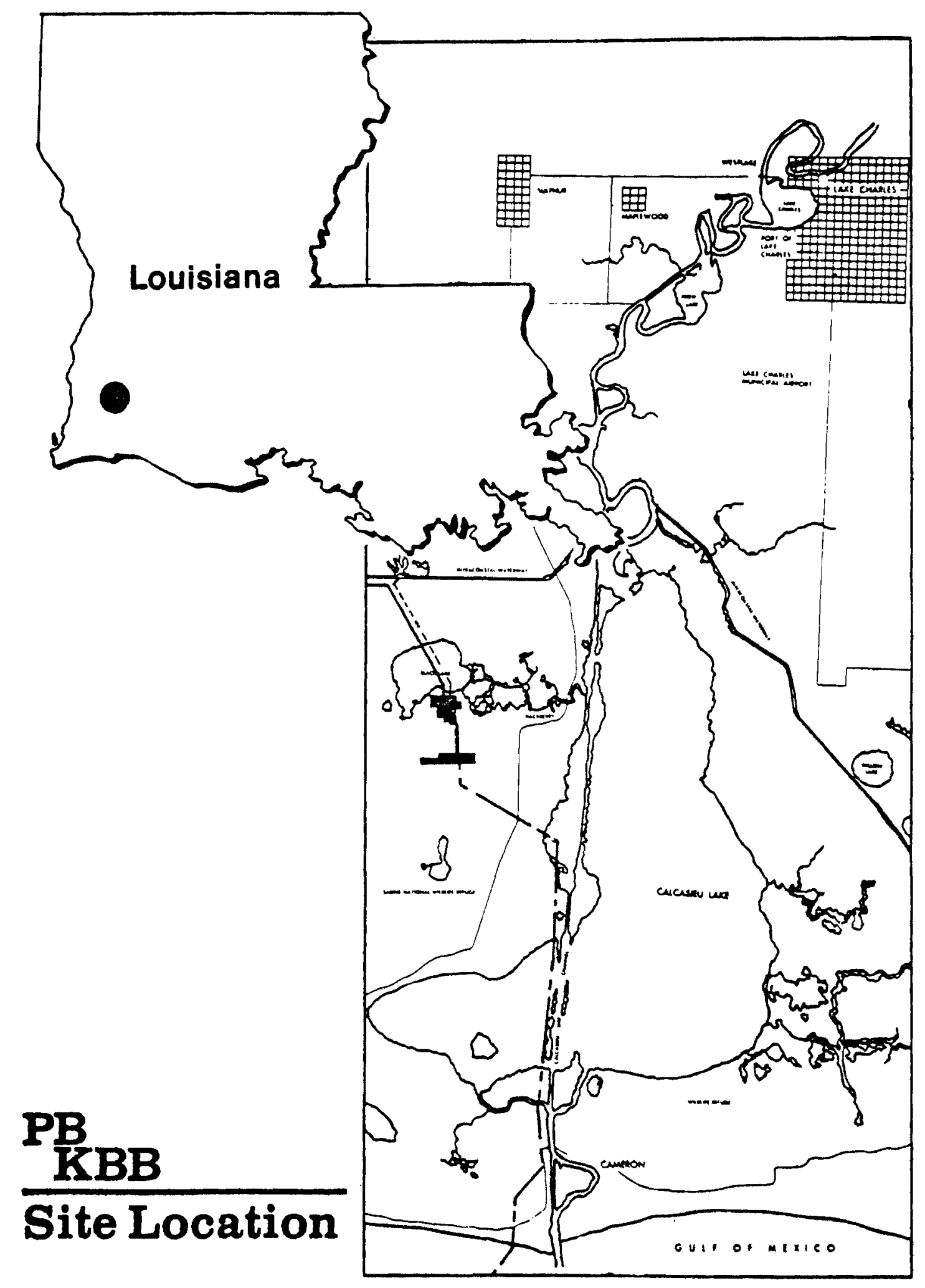




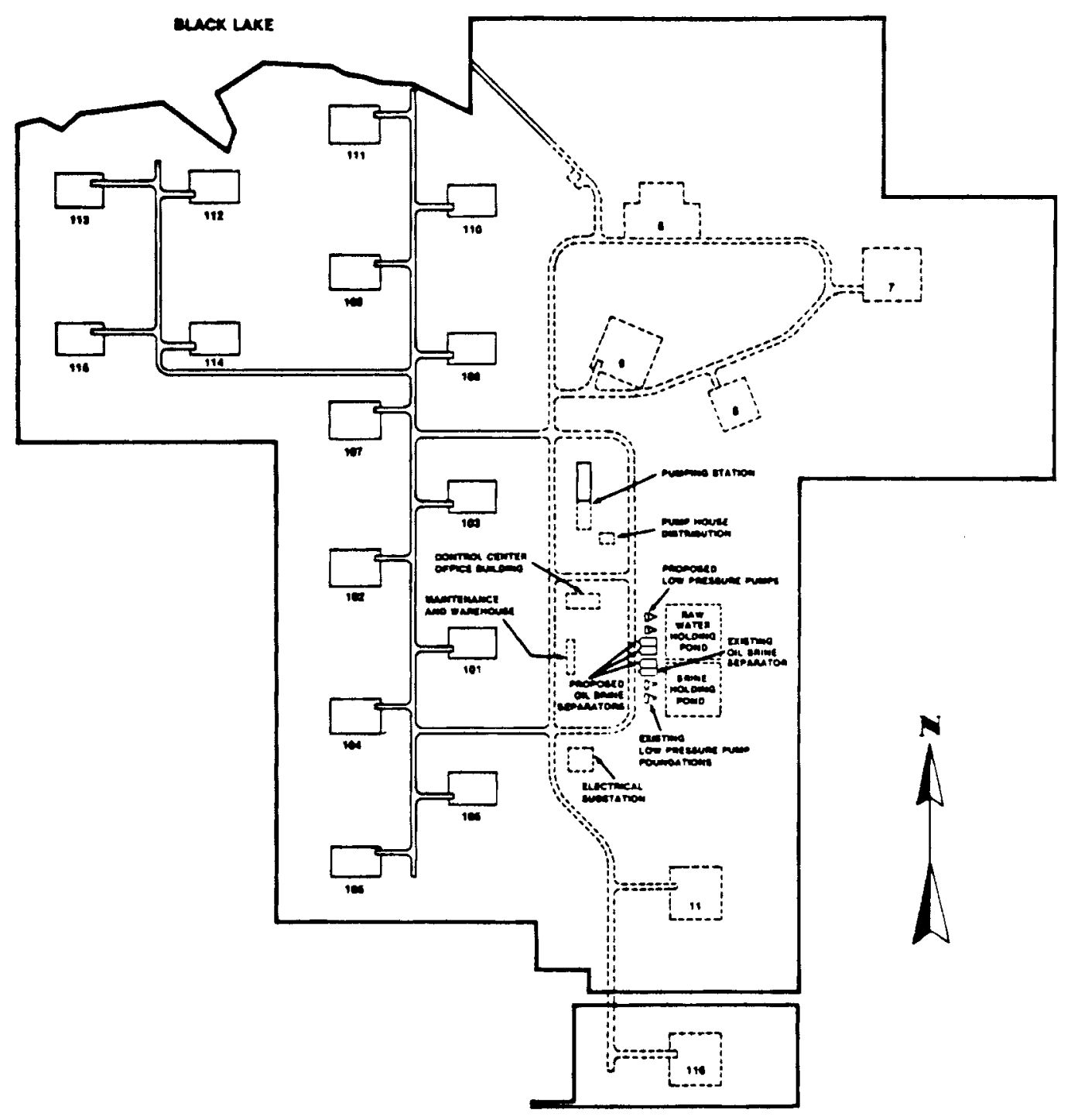

WEST HACKBERRY SITE PLAN 


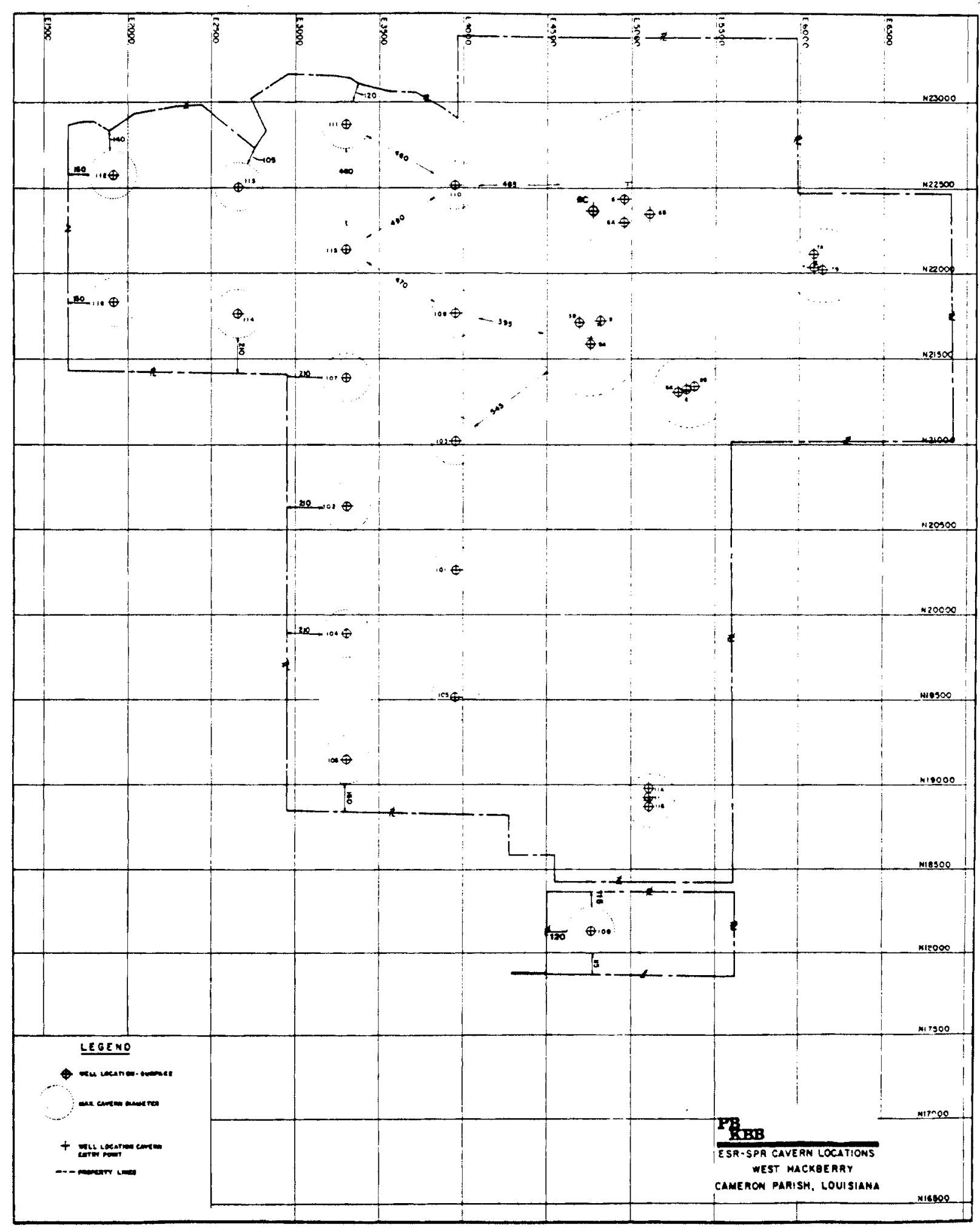




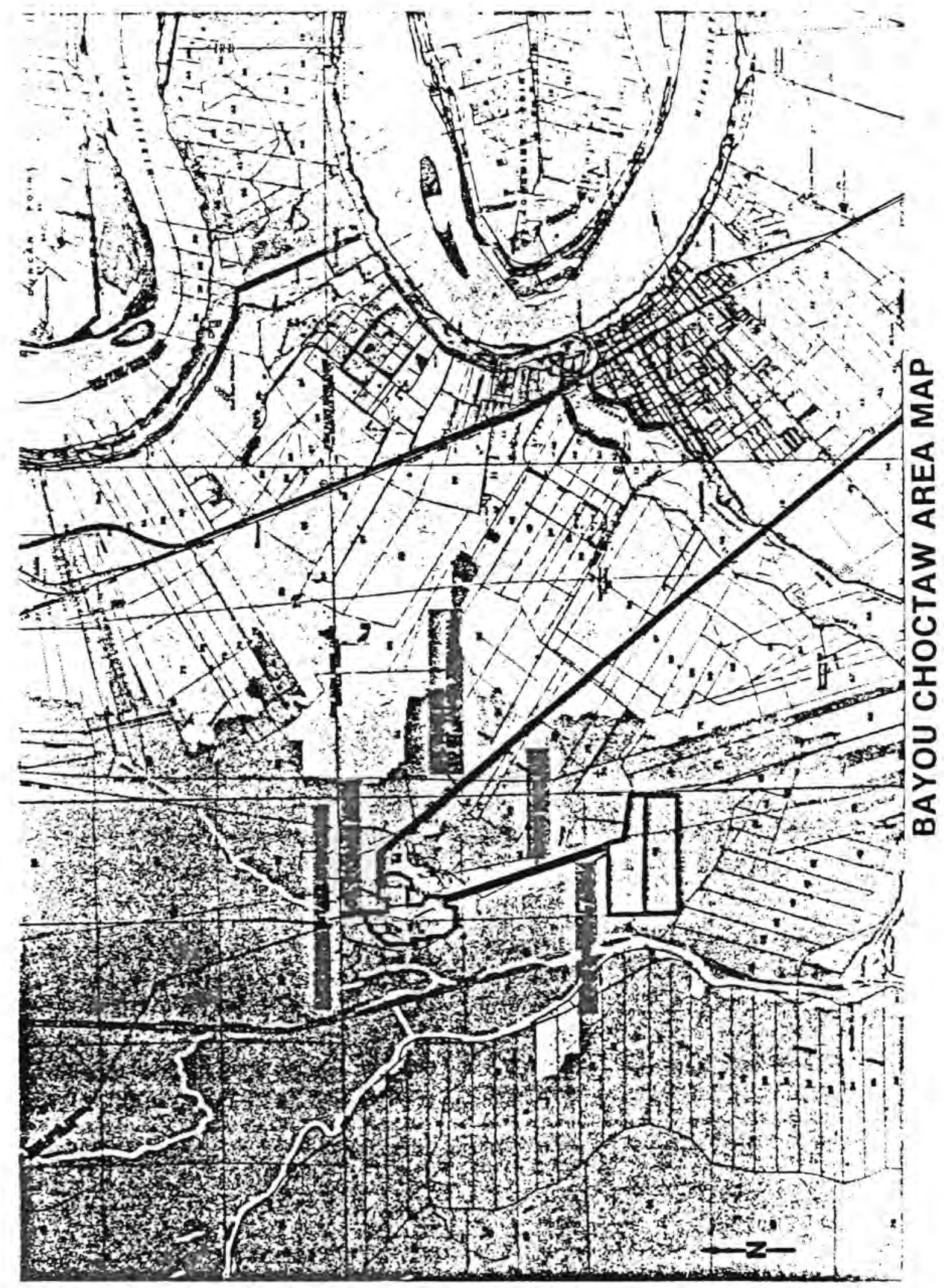




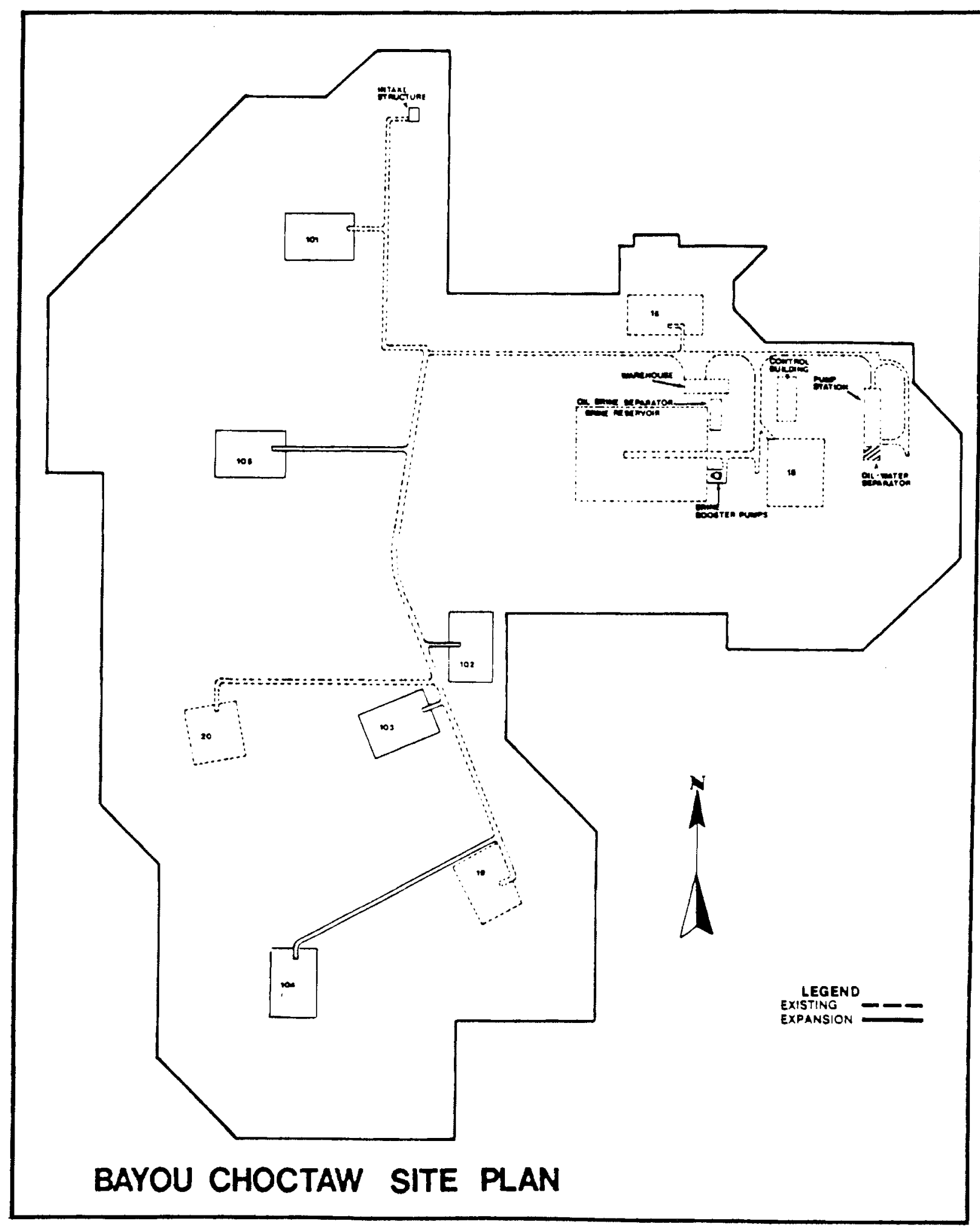




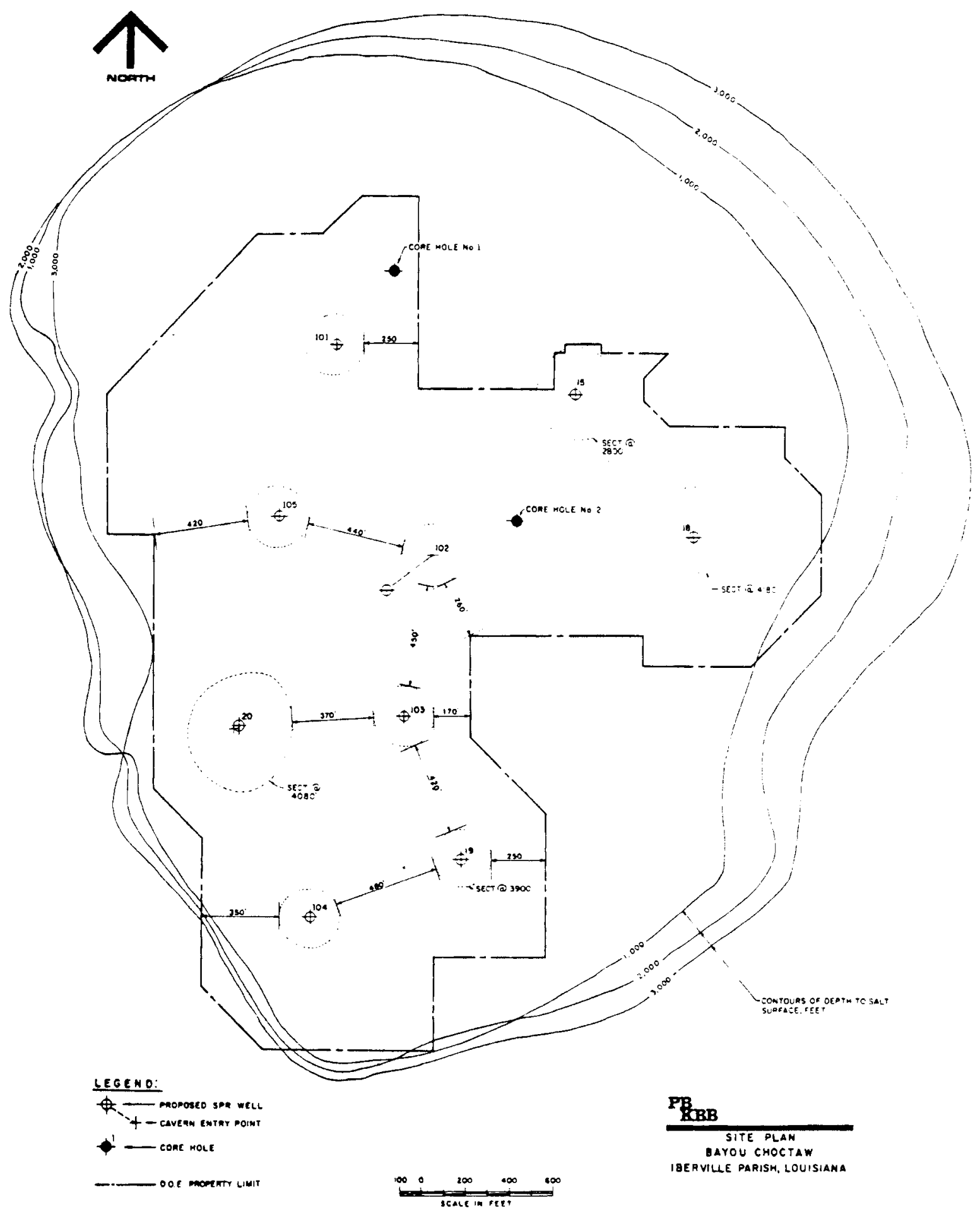




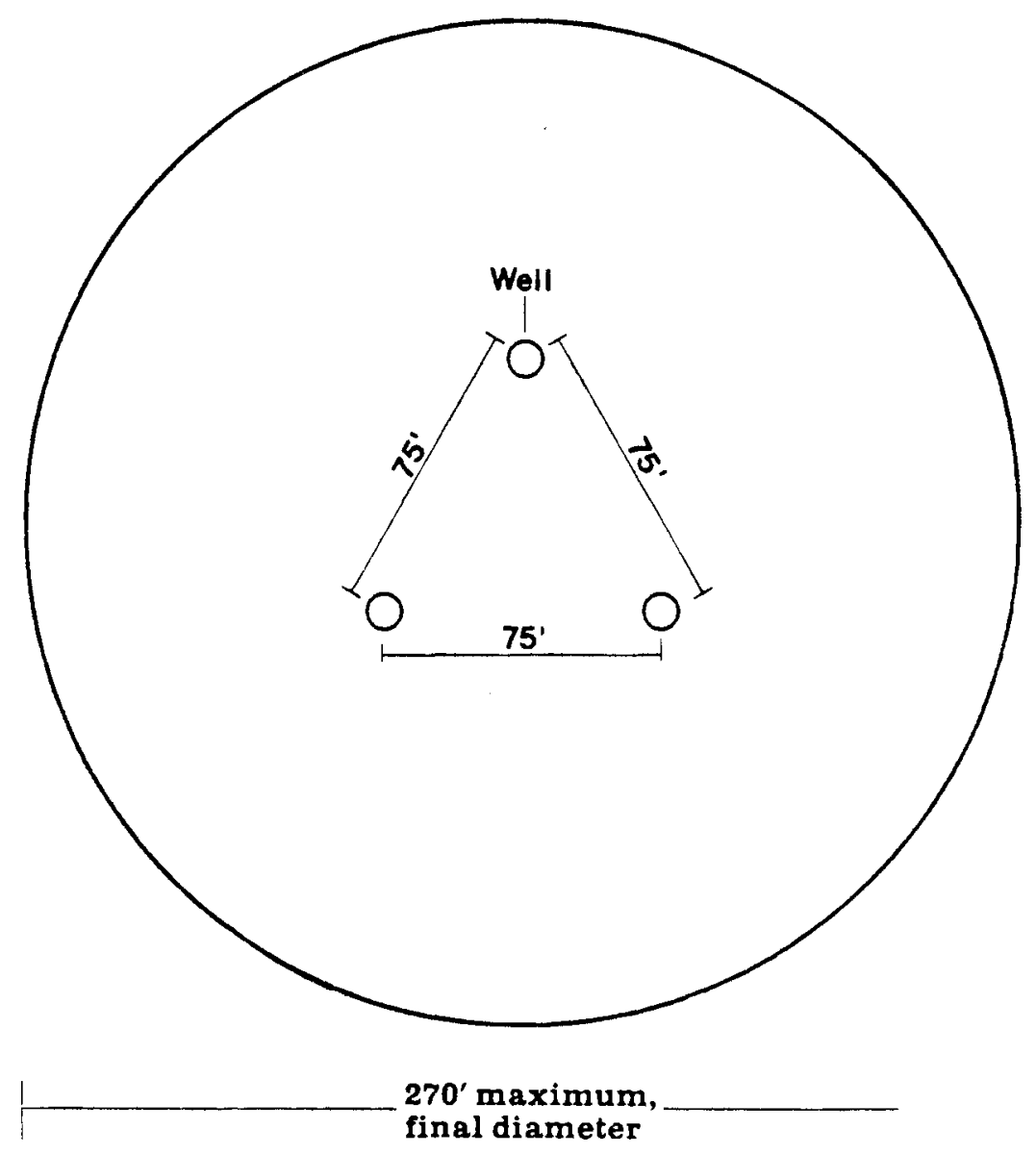

\section{PB \\ Cavern Well \\ Arrangement}




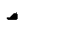

.

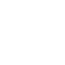

-1
-1

i 


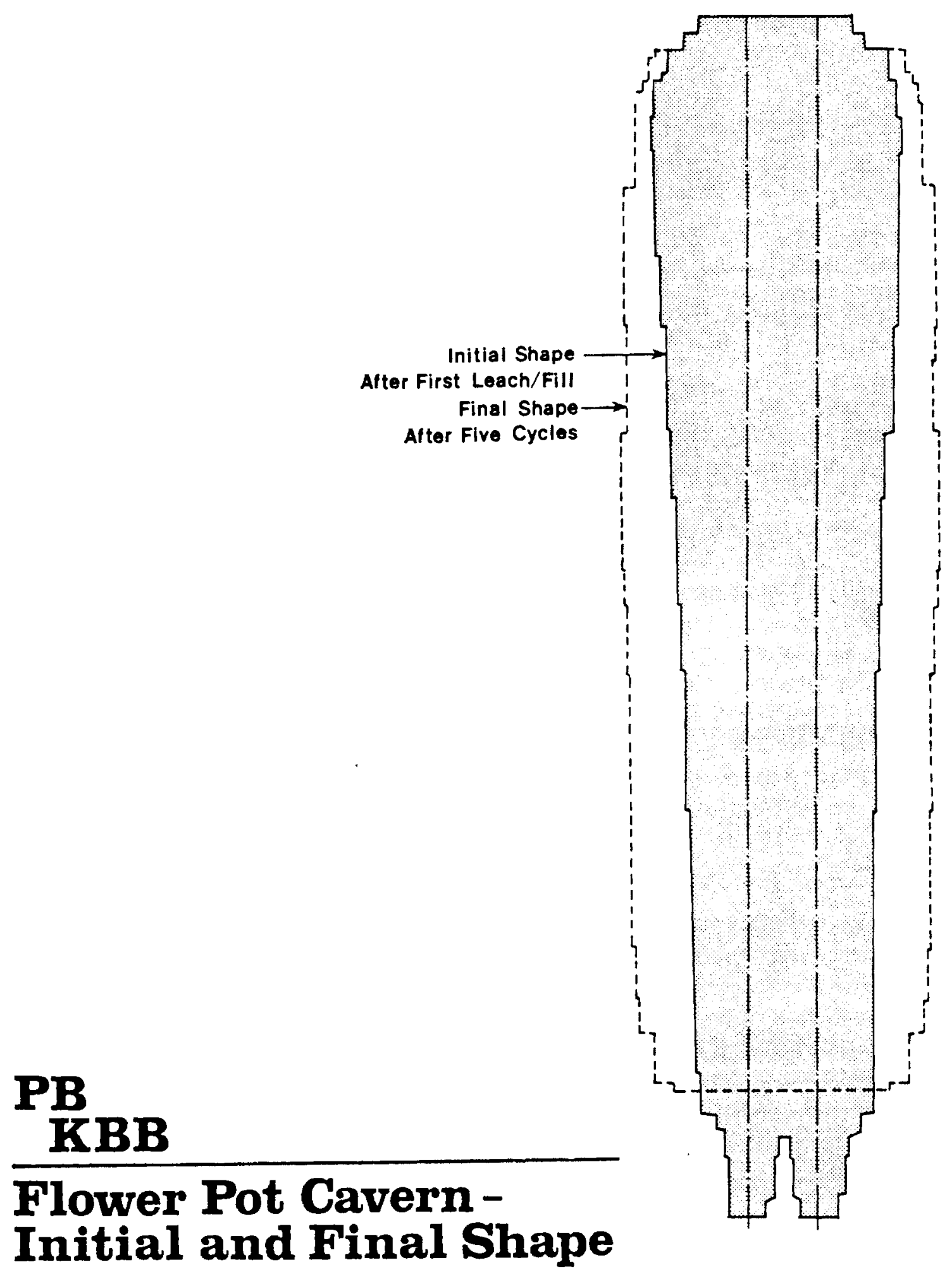




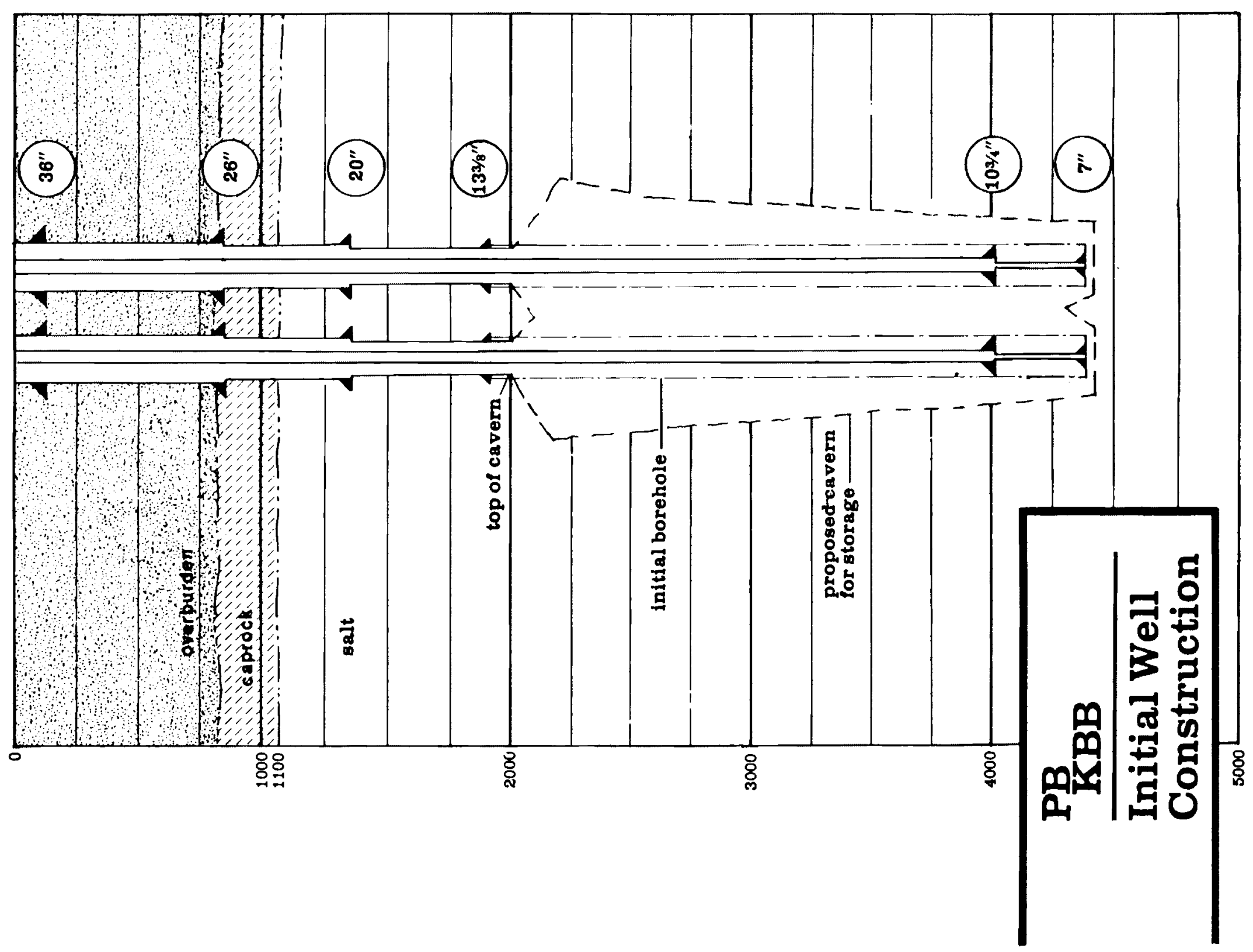

움 


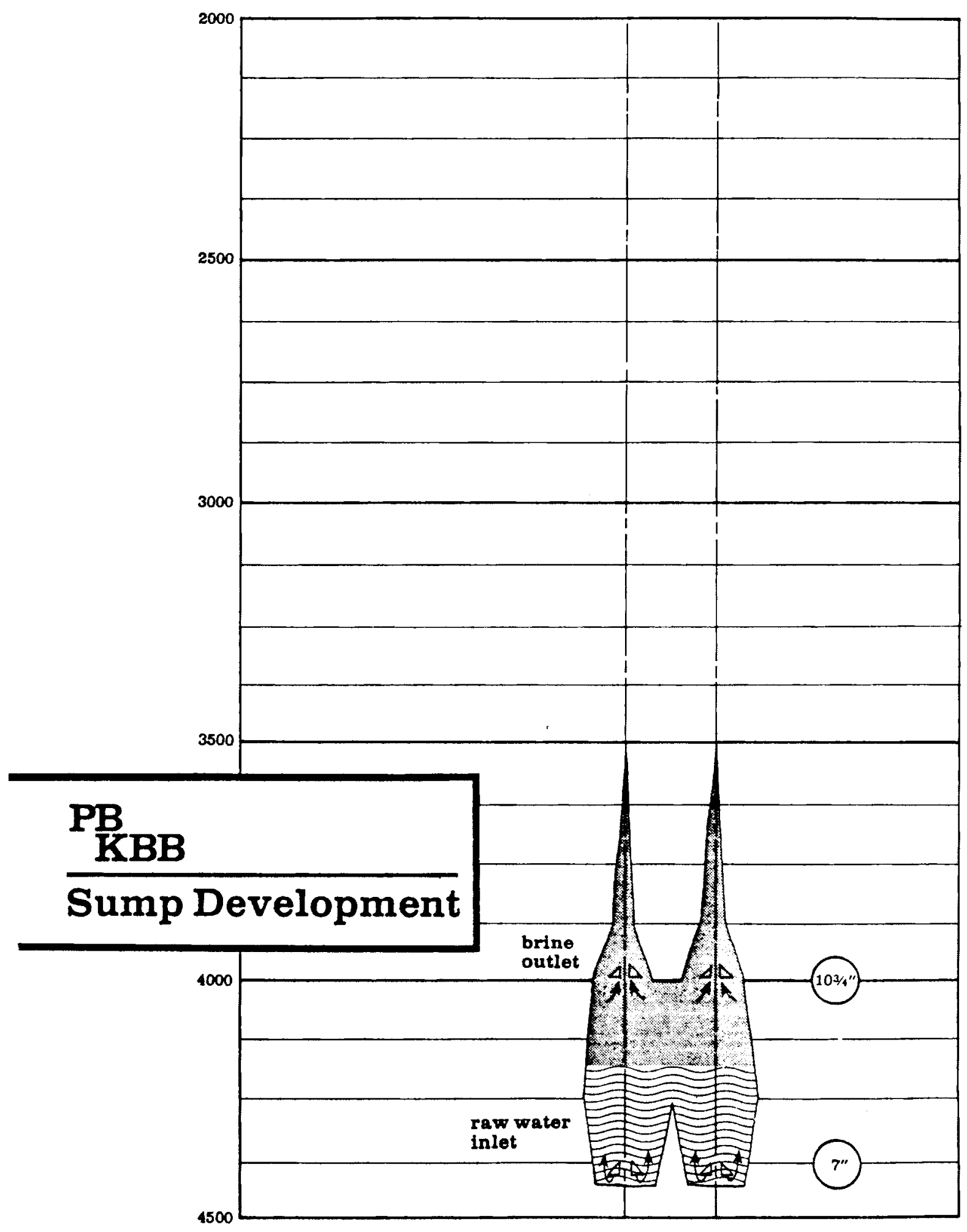

$C-31$ 


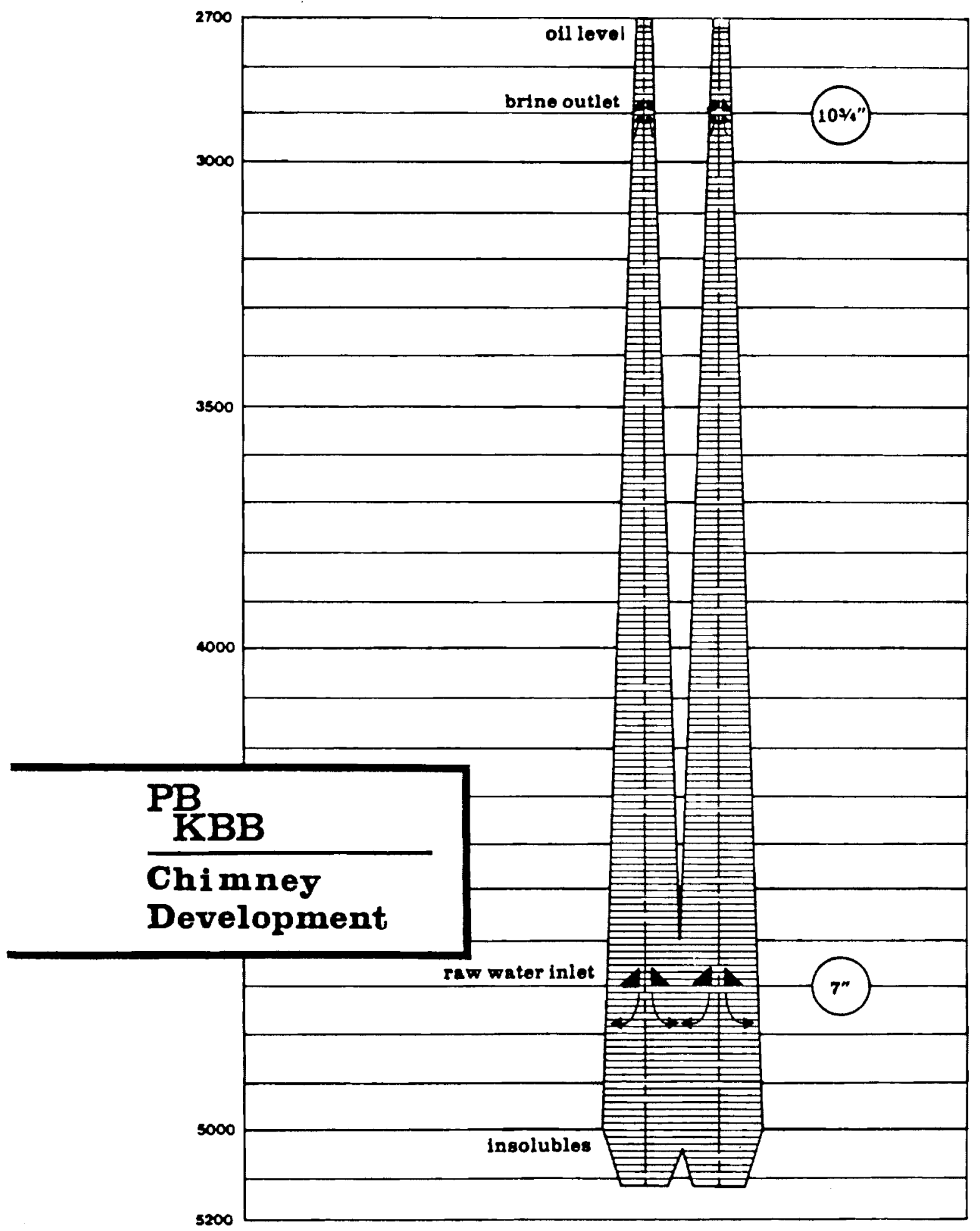




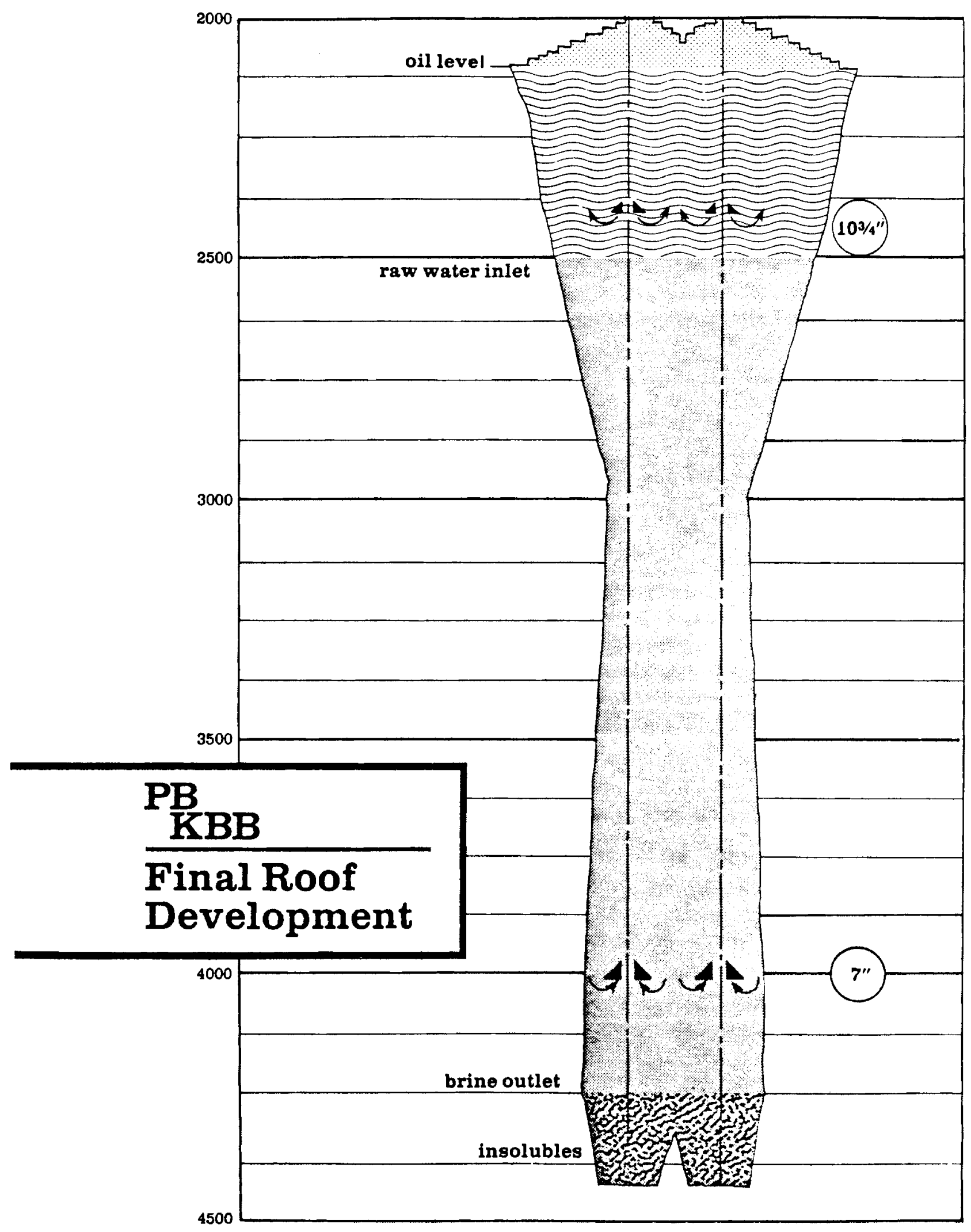




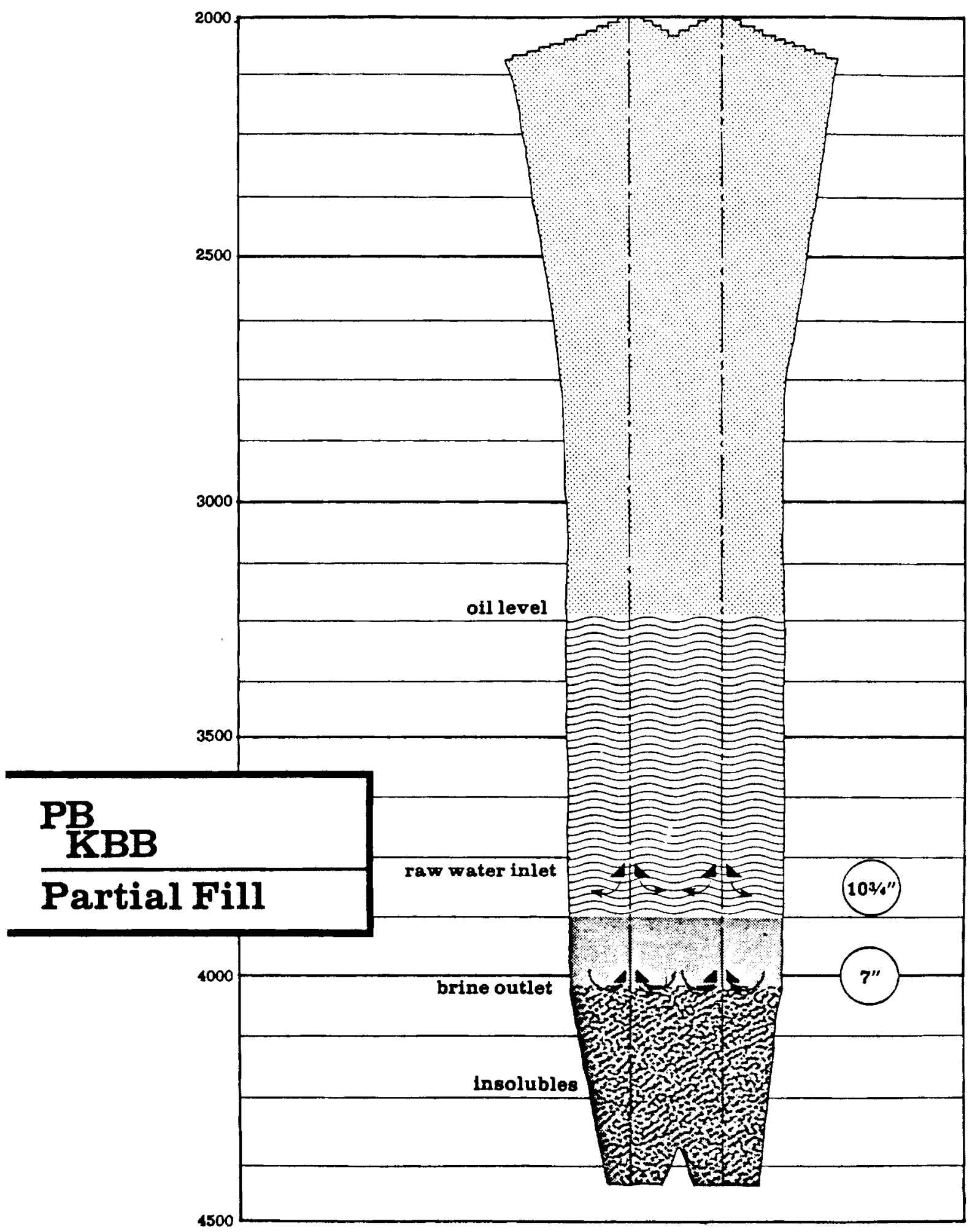




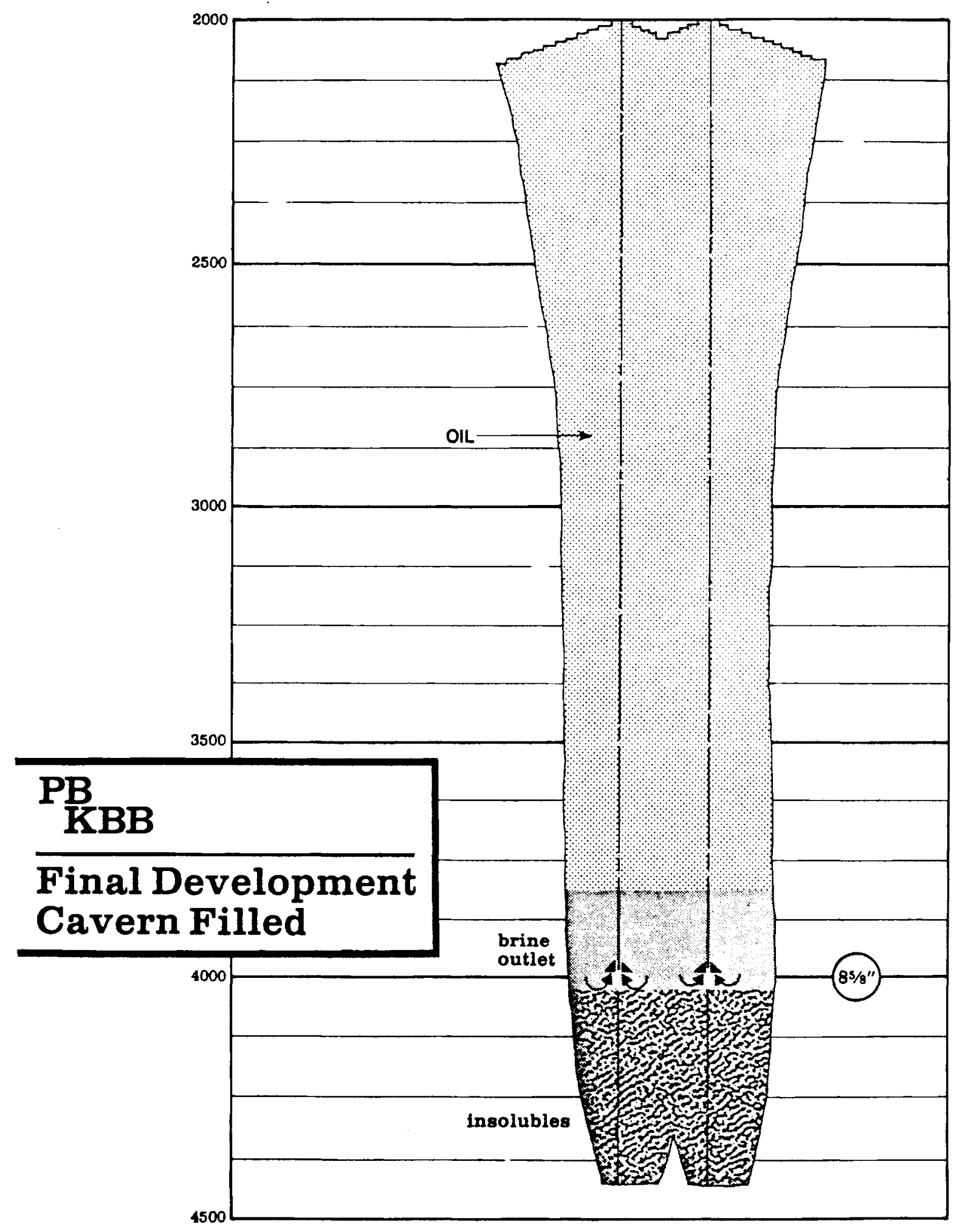




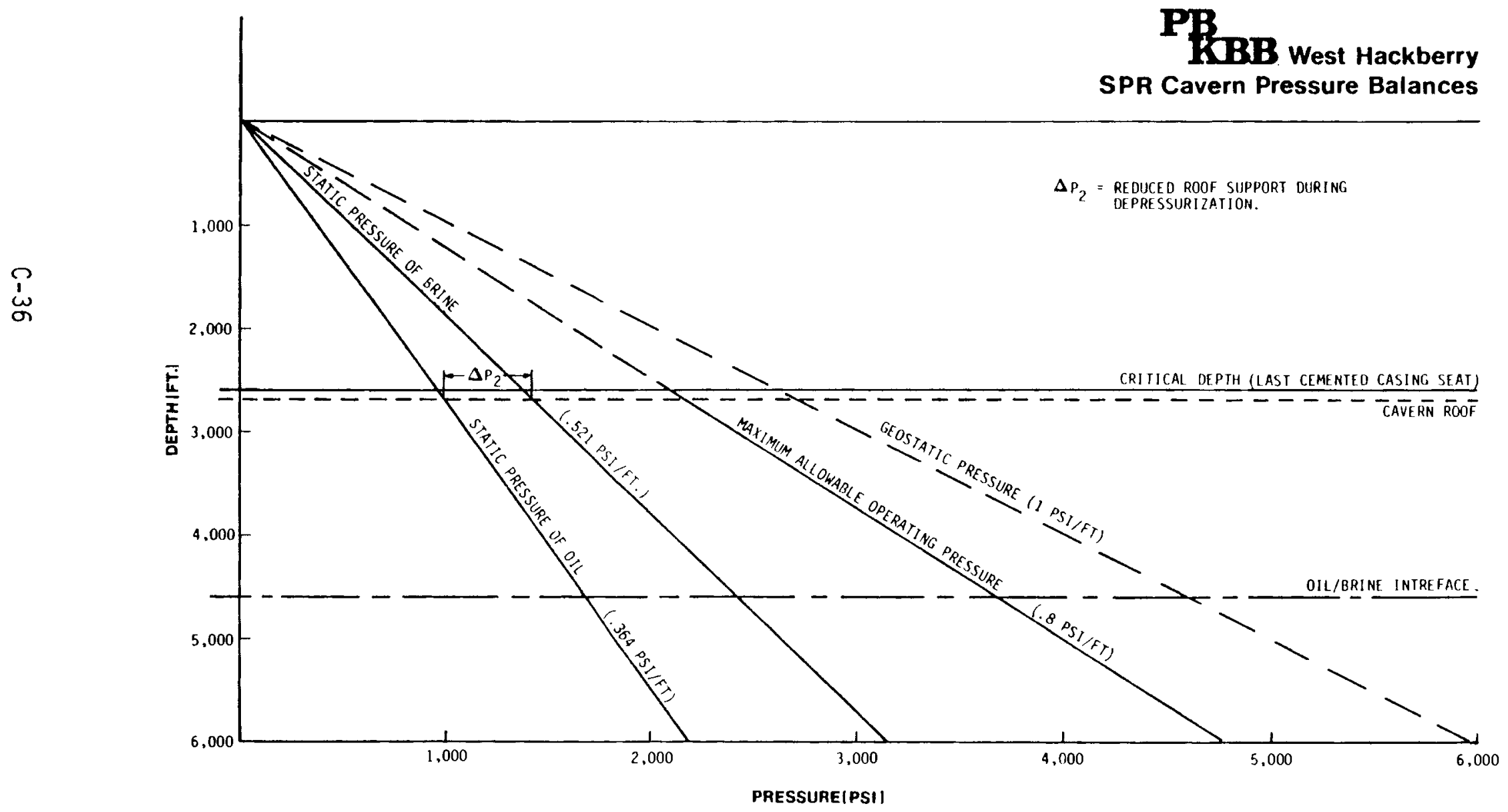




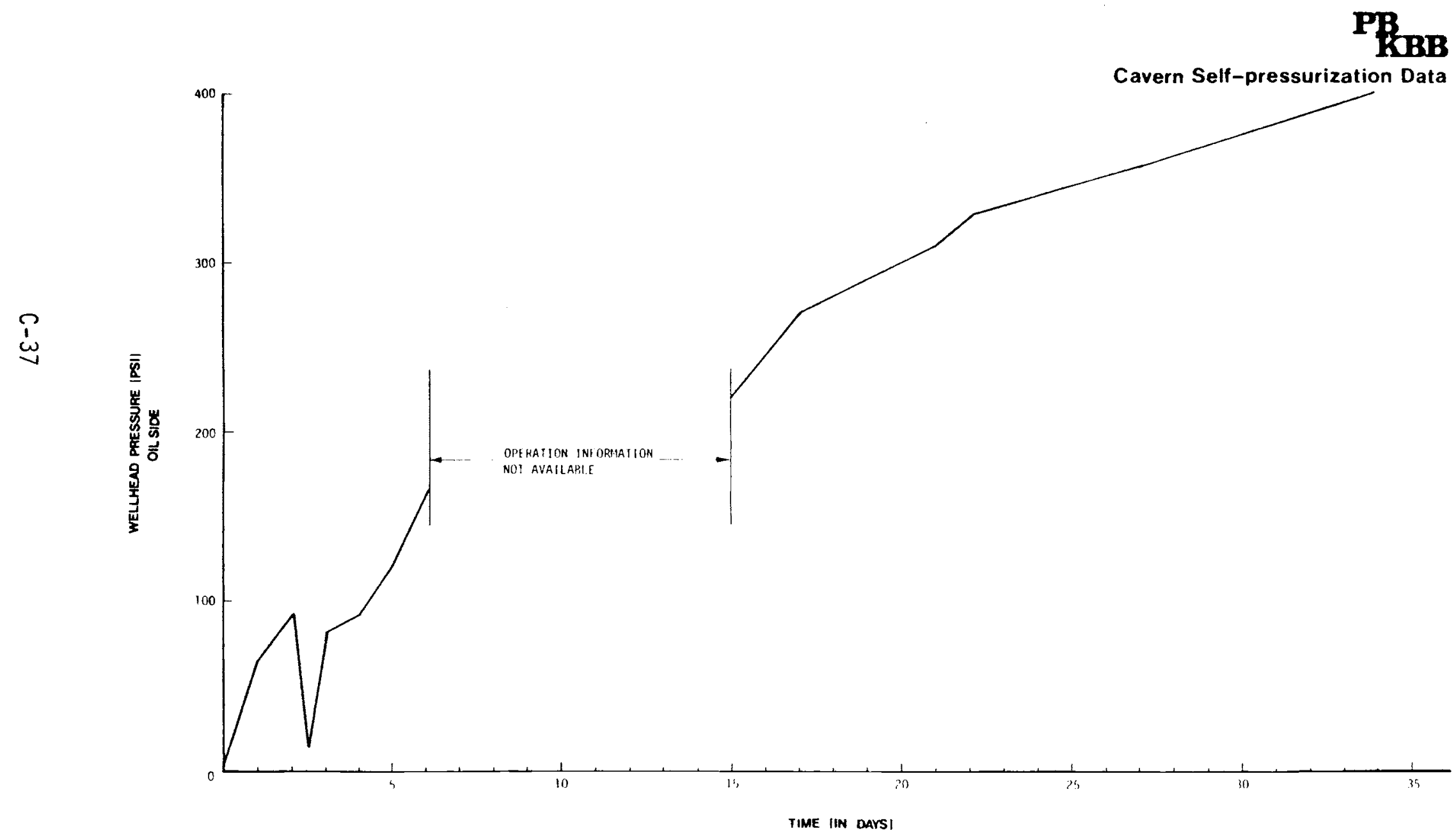




\section{PB}

KBB Bryan Mound

$13 \%$ " SPR Single Well/Cavern

Leach/Fill Design

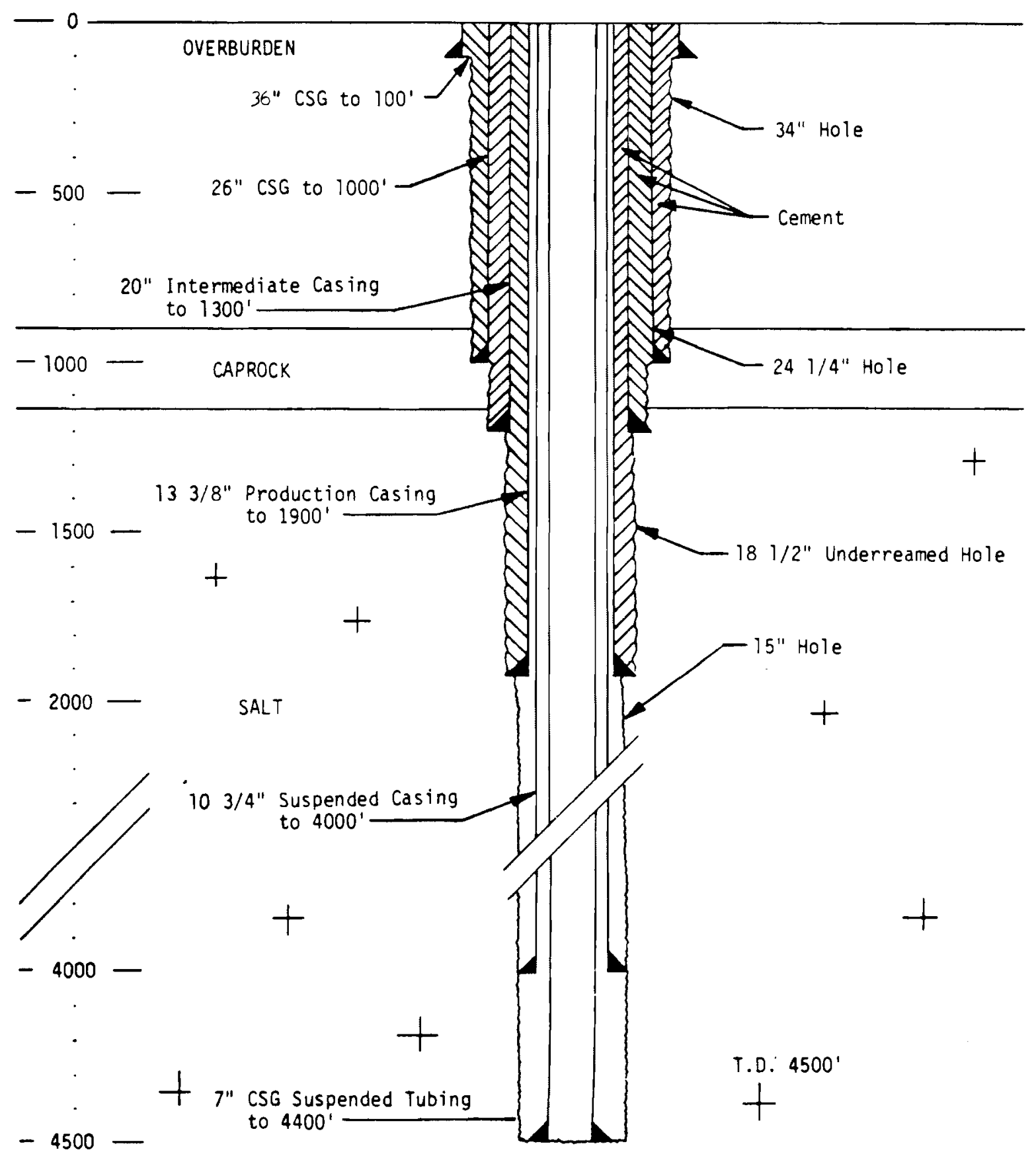




\section{PB}

\section{KBB West Hackberry 1338" SPR Single Well/Cavern Leach/Fill Design}

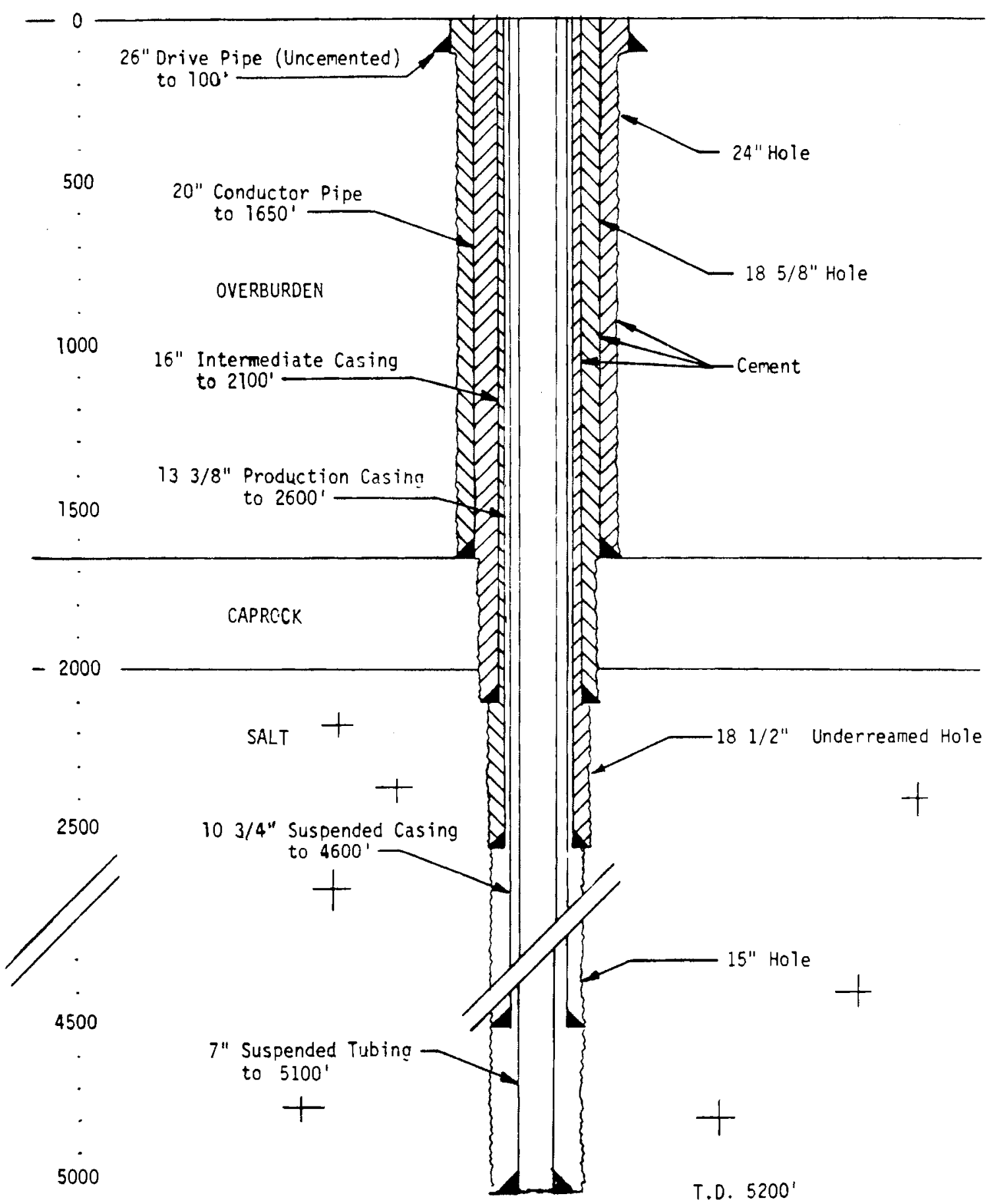




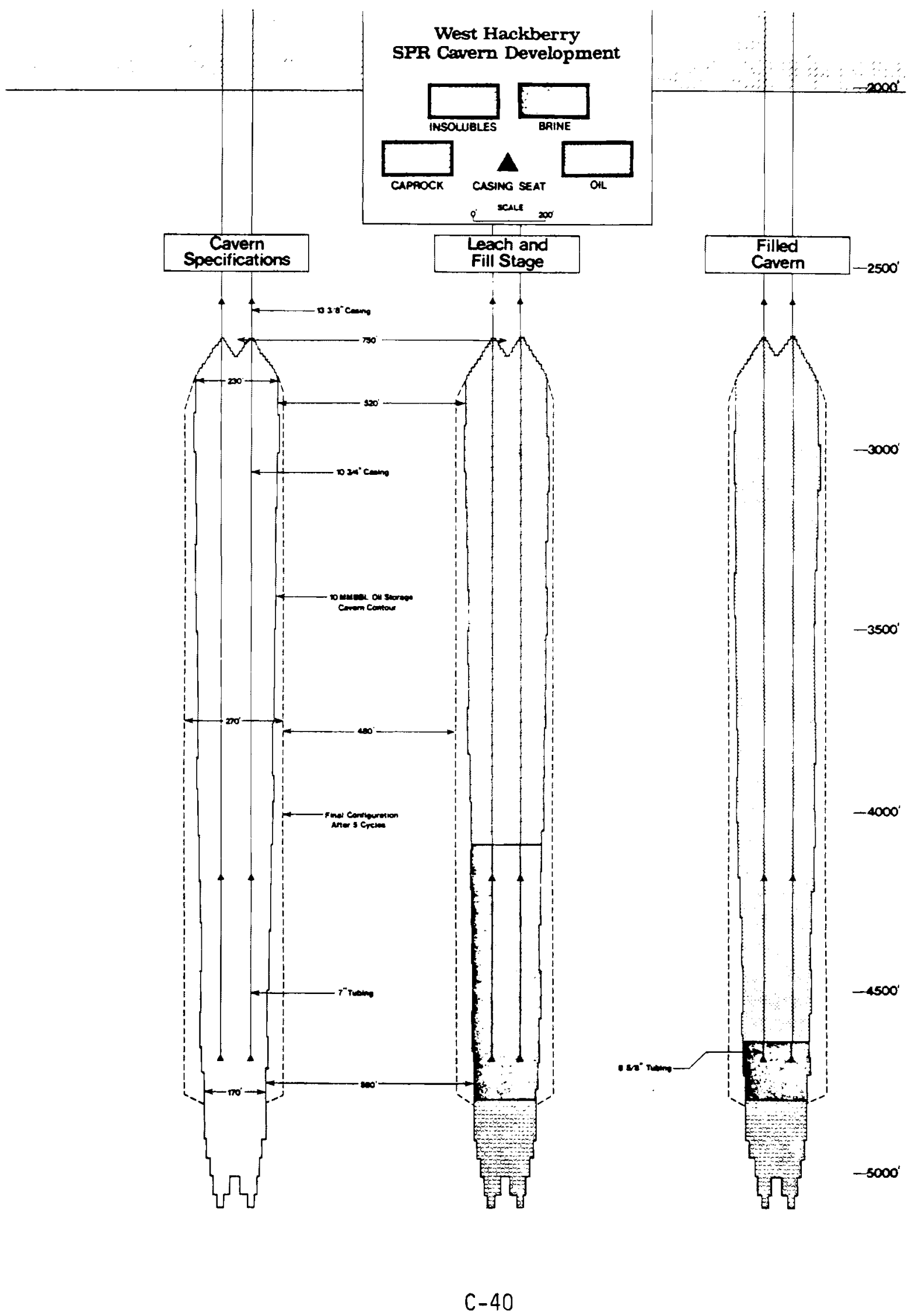




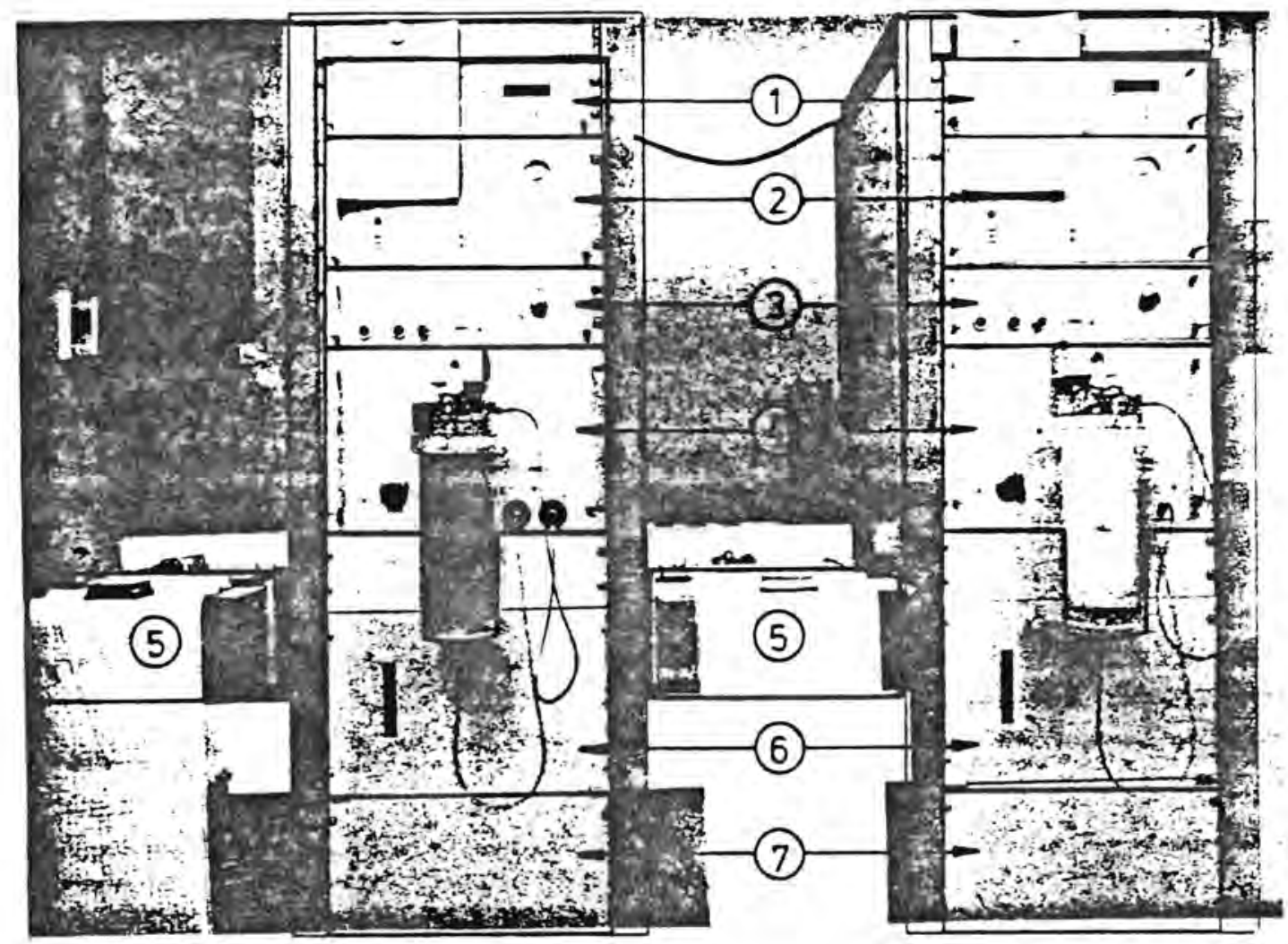

(1) Digital density scales

for determining the specific gravity of the brine

(2) Metering unit

includes facilities for electronic adjustment of brine temperature, metering electronics and operating elements for the calibration of the parameters to be determined

(3) control unit

controls and supervises brine flow and sampler

(4) scales

self-balancing, electronically determines the absolute weight of the salt sample and provides a $D C$ tension proportional to the weight of the sample

(5) Recording unit

simultaneous recording of a maximum of $s i x$ parameters

(6) sampler

automatically abstracts up to 20 specimens from the brine flow for further chemical analysis; time of sampling, quantity and number of specimens are programable

(7) power pack

1solating transformer for protection against contact 


\section{PB \\ KBB Typical SPR Cavern Wellhead}

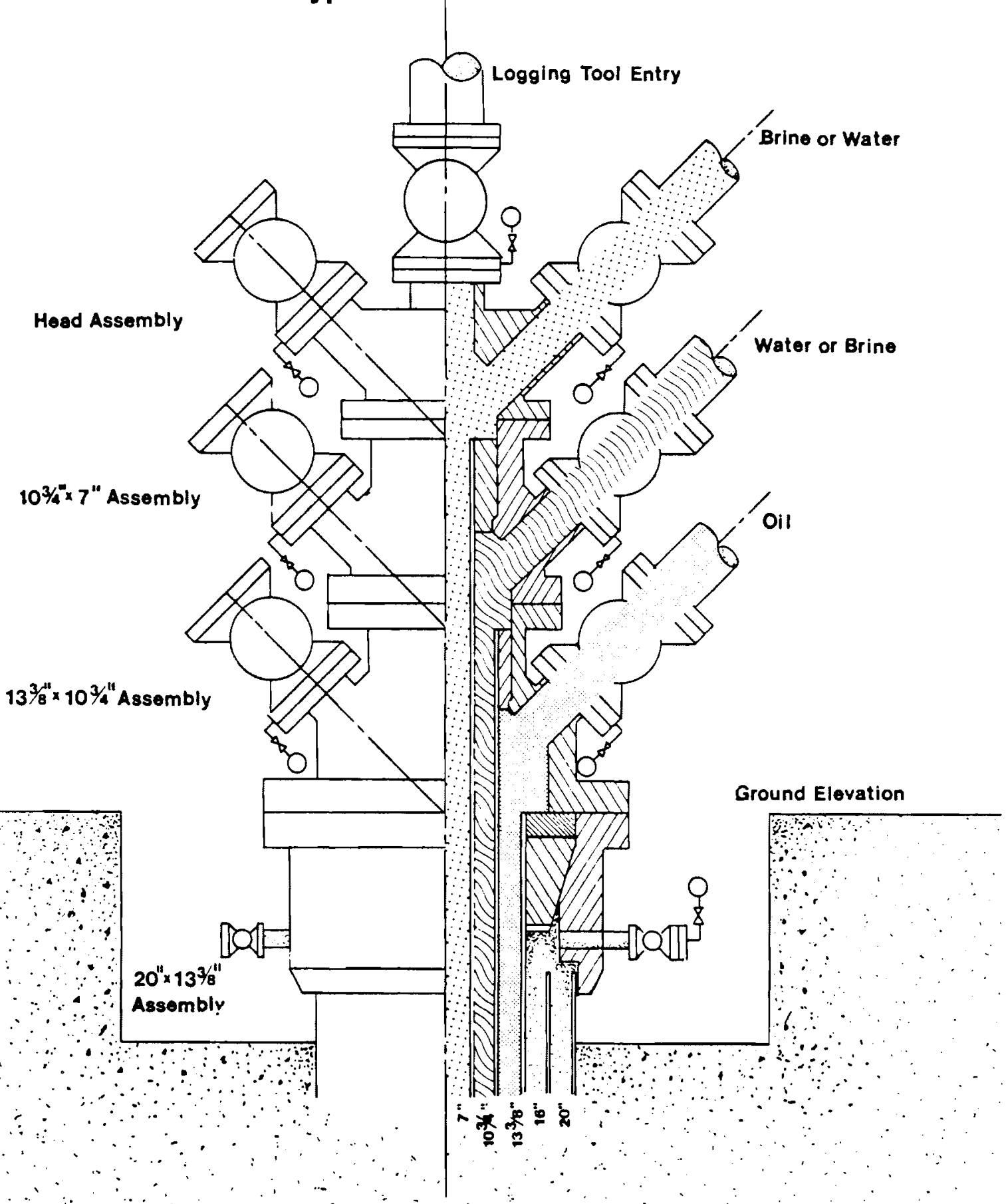




\section{PB \\ KBB Typical SPR Cavern Well head Head Assembly Removed}

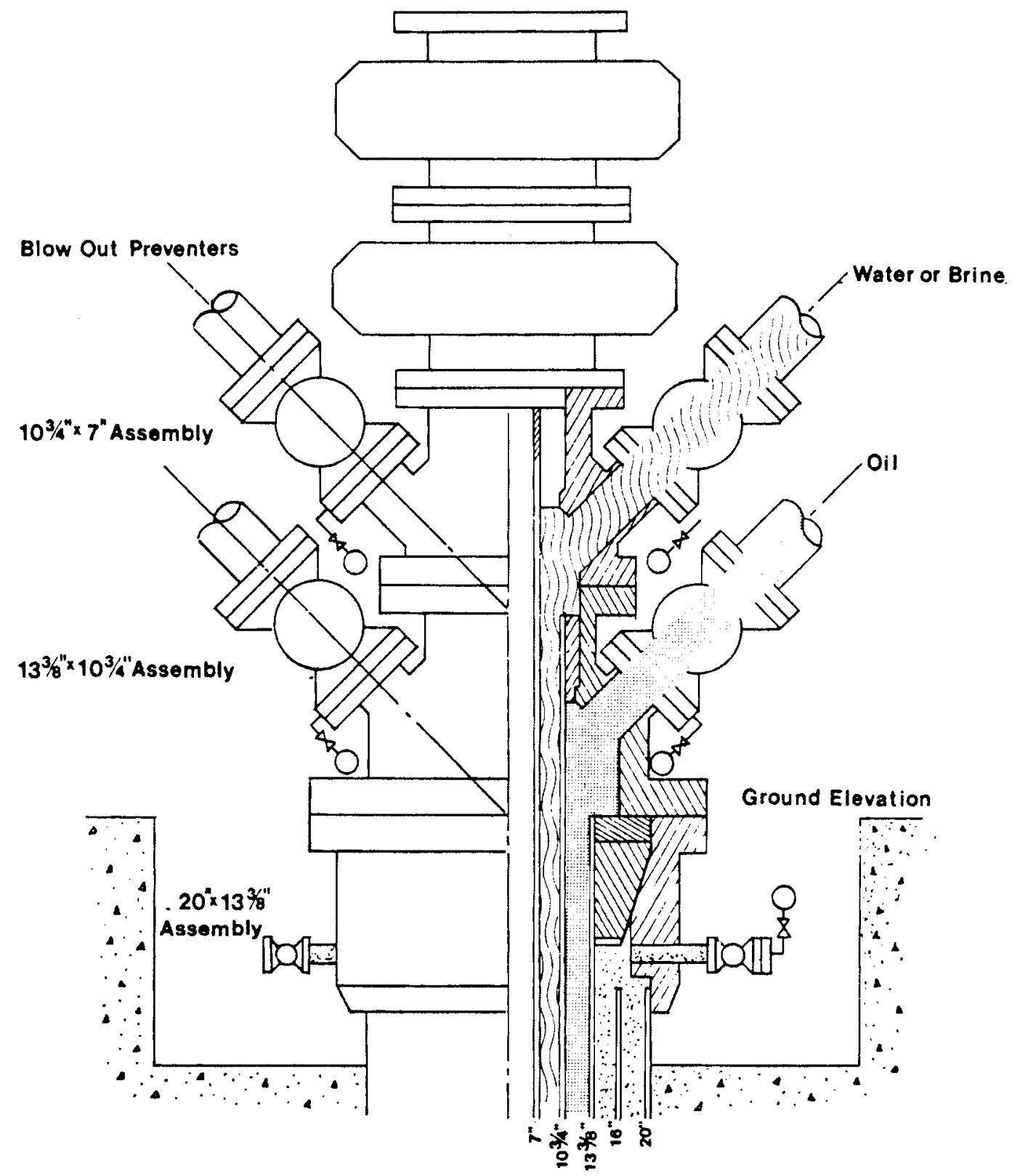




\section{PB \\ KBB Typical SPR Cavern Wellhead 7" Tubing and Assembly Removed}

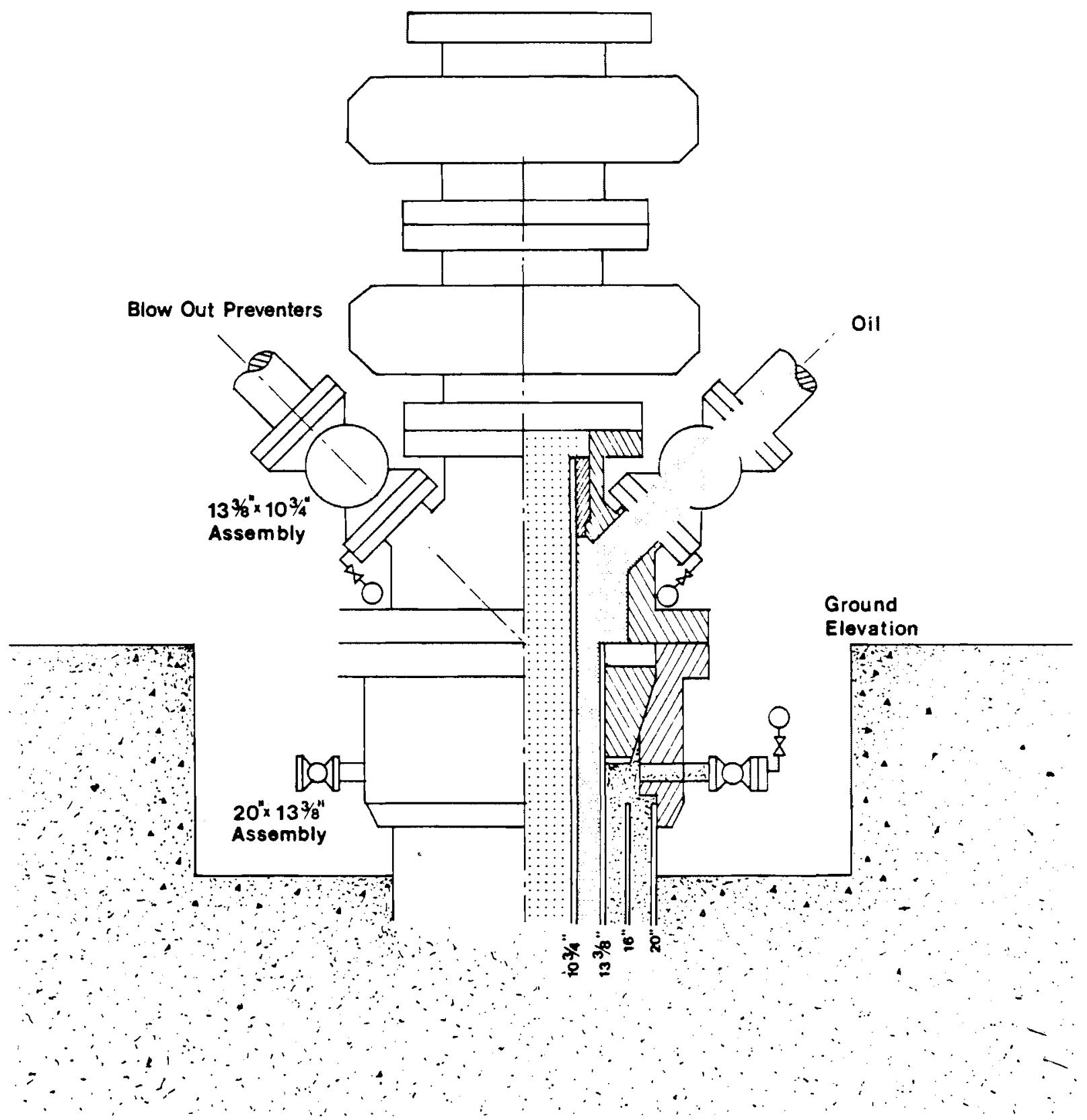




\section{PB \\ KBB Typical SPR Cavern Wellhead 7"\& 103/4" Casing Removed}

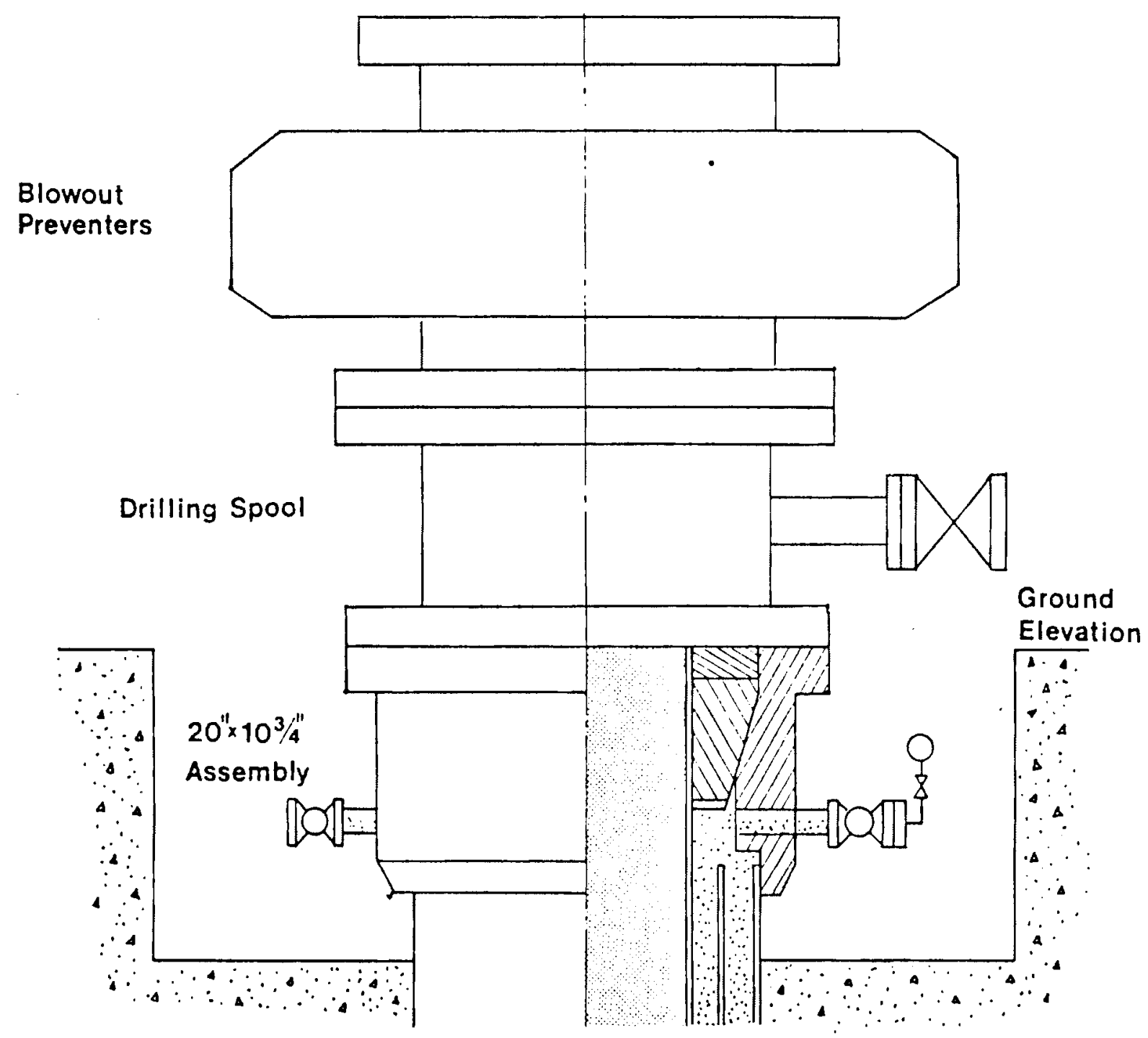




\section{$\checkmark$}

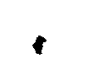

-

$\cdot$

,

c. 


\section{DISTRIBUTION}

No. of

Copies

OFFSITE

UNITED STATES

Michael J. Bel1, Chief

High-Level Waste Technical Development Branch

Waste Management Division

U.S. Nuclear Regulatory Commission

Washington, DC 20555

John Bird

Geology Department

Corne11 University

Ithaca, NY 14853

Charles L. Blalock

Mississippi Department of Natural Resources

Box 20305

Jackson, MS 39209

Albin Brandstetter

Battelle Memorial Institute

Office of Nuclear Waste Isolation

505 King Avenue

Columbus, $\mathrm{OH} 43201$

Colin Bull

Office of the Dean

College of Math and Physics Sciences

154 Denny Hall

164 West 17th Avenue

Columbus, $\mathrm{OH} 43210$

Harry C. Burkholder

Battelle Memorial Institute

Office of Nuclear Waste Isolation 505 King Avenue

Columbus, $\mathrm{OH} 43201$
No. of

Copies
Wayne A. Carbiener

Battelle Memorial Institute

Office of Nuclear Waste Isolation 505 King Avenue

Columbus, $\mathrm{OH} 43201$

C. Ping Chen

Task Force Vice Chairman

Office of Nuclear Waste Isolation

Battelle Columbus

505 King Avenue

Columbus, $\mathrm{OH} 43201$

A. A. Churm

DOE Chicago Patent Group

9800 South Cass Avenue

Argonne, IL 60439

Neville G. W. Cook

Department of Materials Science and Mineral Engineering

Hearst Mining Building

University of California

Berkely, CA 94720

Carl R. Cooley

DOE Office of Nuclear Waste Management

Washington, DC 20545

Bruce Crowe

Geological Research

Group G-6

Los Alamos Scientific Laboratory

P.0. Box 7663

Los Alamos, NM 87545

Stanley N. Davis, Hydrologist

The University of Arizona

College of Earth Sciences

6540 W. Box Canyon Drive

Tucson, AZ 85705 
No. of

Copies

J. 0. Duguid

Battelle Memorial Institute

Office of Nuclear Waste Isolation

505 King Avenue

Columbus, $\mathrm{OH} 43201$

Dan Egan

Environmental Protection Agency

Office of Radiation Programs

Technology Assessment Division

H. $/ S$ AW 559

Washington, DC 20460

E. S. Fuente

Division of Radiological Health

Mississippi Department of Health

247 Vanderwood Building

Jackson, MS 39208

R. Gastil

Freedom House

8 Frontier Road

Cos Cob, CT 06807

John H. Gervers, Coordinator

State of New Mexico Radioactive Waste Consultant Tank Force

Room 247, State Capitol

Santa Fe, NM 87503

George B. Griswold

Tecolote Corporation

531 Wagontrain Drive, S.E.

Albuquerque, NM 87123

J. T. Halloway

National Academy of Sciences

2101 Constitution Avenue N.W.

Washington, DC 20418

Mark A. Harwell

P.0. Box 667

Cannon Beach, OR 97110

Colin A. Heath

DOE Office of Nuclear Waste

Management

Washington, DC 20545
No. of

Copies

William M. Hewitt

Battelle Memorial Institute

Office of Nuclear Waste Isolation

505 King Avenue

Columbus, $\mathrm{OH} 43201$

Peter L. Hofman

Battelle Memorial Institute

Office of Nuclear Waste Isolation

505 King Avenue

Columbus, $\mathrm{OH} 43201$

Lawrence R. Fitch

Office of Licensing

Systems Integration

Basalt Waste Isolation Project

Rockwel 1 Hanford Operations

P. 0. Box 800

Richland, WA 99352

Maureen Kaplan

TASC

6 Jacob Way

Reading, MA 01867

Ralph Kehle

Turk, Kehle and Associates

7800 Schoal Creek Blvd

Suite 270-S

Austin, TX 78752

Muzaffer Kehnemuyi

Battelle Memorial Institute

Office of Nuclear Waste Isolation

505 King Avenue

Columbus, $\mathrm{OH} 43201$

John F. Kircher

Battelle Memorial Institute

Office of Nuclear Waste Isolation

505 King Avenue

Columbus, $\mathrm{OH} 43201$

C. Kreitler

Texas Bureau of Economic Geology

University Station

P.0. Box X

Austin, TX 78712 
George Kukla

Lamont-Doherty Geological Observatory of Columbia University

Palisades, NY 10964

Donald H. Kupfer

Louisiana State University

Shreveport, LA 71105

Terry R. Lash

Director of Science and

Public Policy

Keystone Center

Box 38

Keystone, c0 80435

Joseph A. Lieberman

Nuclear Safety Associates

5101 River Road

Bethesda, MD 20016

\section{J. Martinez}

Louisiana State University

Shreveport, LA 71105

John T. McGinnis

Battelle Memorial Institute

Office of Nuclear Waste Isolation

505 King Avenue

Columbus, $\mathrm{OH} 43201$

M. Merritt

WIPP

Sandia Laboratories

Albuquerque, NM 87115

Vernon Minchew

Mississippi Mineral Resources Inst.

U. of Mississippi

Oxford, MS 38677

Jack Mobley

Scientific Liaison Officer

State of New Mexico Environmental

Evaluation Group

320 E. Marcy Street

Santa Fe, NM 87503
J. 0. Neff

Department of Energy

Columbus Program Office

505 King Avenue

Columbus, $\mathrm{OH} 43201$

Robert H. Nei11

Environmental Evaluation Group

State of New Mexico

P.0. Box 968

Santa Fe, NM 87503

John D. Osnes

RE/SPEC Inc.

P.0. Box 725

Rapid City, SD 57709

Frank L. Parker

Department of Environmental Eng.

Vanderbilt University

Nashville, TN 37235

T. H. Pigford

University of California

Berkely, CA 94720

George F. Pinder

Department of Civil Engineering

Princeton University

Princeton, NJ 08540

Robert 0. Pohl

Laboratory of Atomic and

Solid State Physics

Cornell University

Ithaca, NY 14853

B. J. Porter

Louisiana Office of Environmental

Affairs

Nuclear Energy Division

P.0. Box 14690

Baton Rouge, LA 70898

H. L. Ragsdale

Department of Biology

Emory University

Atlanta, GA 30322 
Gi Tbert E. Raines

Battelle Memorial Institute

Office of Nuclear Waste Isolation

505 King Avenue

Columbus, $\mathrm{OH} 43201$

Marvin Resnikoff

Sierra Club

Box 64, Station $G$

Buffalo, NY 14213

David L. Schreiber

Consulting Hydraulic Engineer

P.0. Box 1087

(c/o the Colony)

Couer D'Alene, ID 83874

Dorner T. Schueler, Manager

Waste Isolation Pilot Project

Albuquerque Operations office

U.S. Department of Energy

P.0. Box 5400

Albuquerque, NM 87115

Herbert R. Shaw

U.S. Department of the Interior

Geological Survey

Branch of Experimental Geochem. and Mineralogy

345 Middlefield Road

Men low Park, CA 94025

D. B. Shipler

Battelle Memorial Institute

Office of Nuclear Waste Isolation

505 King Avenue

Columbus, $\mathrm{OH} 43201$

Raymond Siever

Hoffman Laboratory

Harvard University

Cambridge, MA 02138

Arthur J. Soinski

State of California Energy

Resources Conservation and

Development Commission

1111 Howe Avenue

Sacramento, CA 95825
Howard P. Stephens

NTS Waste Management

Overview Division 4538

Sandia Laboratories

Albuquerque, NM 87115

David B. Stewart

Geologic Division Coordinator

Radioactive Waste Management

U.S. Department of the Interior

959 National Center

Reston, VA 22092

Martin S. Tierney

Environmental Assessment

Division 4514

Sandia Laboratories

Albuquerque, NM 87115

Newell J. Trask, Geologist

U.S. Department of the Interior

Geological Survey

Reston, VA 22092

Morton E. Wacks

Department of Nuclear Engineering

University of Arizona

Tucson, AZ 85721

Peter J. Walley

Office of Energy Commission

Suite 228, Barefield Complex

455 N. Lamar Street

Jackson, MS 39201

Bob E. Watt

1447 45th Street

Los Alamos, NM 87544

G. Wermund

Texas Bureau of Economic Geology

University Station

P.O. Box $X$

Austin, TX 78712 
No. of

Copies

R. E. Wilems

INTERA Environmental

Consultants, Inc.

11999 Katy Freeway, Suite 610

Houston, TX 77079

John Winchester

Department of Oceanography

Florida State University

Tallahassee, FL 32306

Paul Witherspoon

Head, Earth Sciences Division

Lawrence Berkeley Laboratory

University of California

Berkeley, CA 94720

ONSITE

4 DOE Richland Operations Office

P. A. Craig (2)

R. B. Goranson

H. E. Ransom

Hanford Engineering Development Laboratory

M. J. Barr

Rockwell Hanford Operations

R. A. Deju
No. of

Copies

36 Pacific Northwest Laboratory

G. L. Benson

T. D. Chikalla

C. R. Cole

W. J. Deutsch

F. H. Dove (10)

M. G. Foley

M. R. Kreiter

J. K. Soldat

J. T. Zellmer

Technical Information Library (5)

Publishing Coordination (2) Water and Land Resources Department Library (10) 
